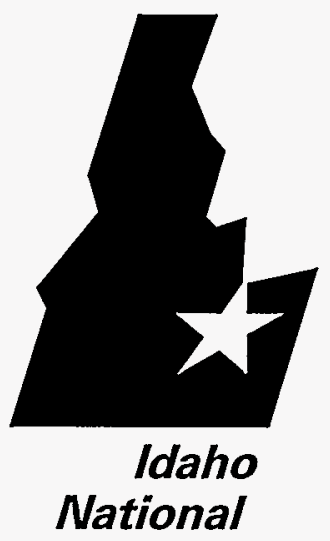

Engineering Laboratory
INEEL/EXT-97-01138

February 1998

\title{
HIGH PERFORMANCE APCS CONCEPTUAL DESIGN AND EVALUATION SCOPING STUDY
}

\author{
RECEIVED \\ MAY O? 1998 \\ OSTI
}

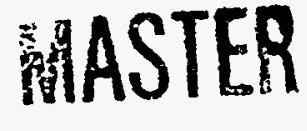

Nick Soelberg DISTAIBUTION OF THIS DOCUMENT IS UNLIMITEC Kevin Liekhus

Andrea Chambers

Gary Anderson

LOCKHEED MATTIN 


\section{DISCLAIMER}

This report was prepared as an account of work sponsored by an agency of the United States Government. Neither the United States Government nor any agency thereof, nor any of their employees, makes any warranty, express or implied, or assumes any legal liability or responsibility for the accuracy, completeness, or usefulness of any information, apparatus, product, or process disclosed, or represents that its use would not infringe privately owned rights. Reference herein to any specific commercial product, process, or service by trade name, trademark, manufacturer, or otherwise does not necessarily constitute or imply its endorsement, recommendation, or favoring by the United States Government or any agency thereof. The views and opinions of authors expressed herein do not necessarily state or reflect those of the United States Government or any agency thereof. 


\section{DISCLAIMER}

Portions of this document may be illegible electronic image products. Images are produced from the best available original document. 


\title{
HIGH PERFORMANCE APCS CONCEPTUAL DESIGN AND EVALUATION SCOPING STUDY
}

\author{
Nick Soelberg \\ Kevin Liekhus \\ Andrea Chambers \\ Gary Anderson
}

Published February 1998

Idaho National Engineering and Environmental Laboratory Waste Management Technologies Department Lockheed Martin Idaho Technologies Company Idaho Falls, Idaho 83415

Prepared for the

U.S. Department of Energy

Assistant Secretary for Environmental Management

Under DOE Idaho Operations Office

Contract DE-AC07-94ID13223 



\section{ABSTRACT}

This Air Pollution Control System (APCS) Conceptual Design and Evaluation study was conducted to evaluate a high-performance (APC) system for minimizing air emissions from mixed waste thermal treatment systems. Seven variations of high-performance APCS designs were conceptualized using several design objectives. One of the system designs was selected for detailed process simulation using ASPEN PLUS to determine material and energy balances and evaluate performance. Installed system capital costs were also estimated. Sensitivity studies were conducted to evaluate the incremental cost and benefit of added carbon adsorber beds for mercury control, specific catalytic reduction for $\mathrm{NO}_{\mathrm{x}}$ control, and offgas retention tanks for holding the offgas until sample analysis is conducted to verify that the offgas meets emission limits.

Results show that the high-performance dry-wet APCS can easily meet all expected emission limits except for possibly mercury. The capability to achieve high levels of mercury control (potentially necessary for thermally treating some DOE mixed streams) could not be validated using current performance data for mercury control technologies. If high mercury control cannot be achieved using existing or new technologies, then restrictive feed limits for mercury may become necessary for existing and new mixed waste thermal treatment facilities. Decontamination factors (ratio of the input pollutant mass flowrate and the mass flowrate of the pollutant in the cleaned offgas) for other pollutants were very high $\left(1 \times 10^{9}\right.$ to $\left.4 \times 10^{9}\right)$ because of the cumulative effectiveness of several different APCS components.

Installed APCS capital costs for two different cases ranged from $\$ 27$ million to $\$ 46$ million, depending on the offgas flowrate and system design. Offgas retention tanks could add hundreds of millions of dollars to the APCS capital costs and could significantly increase the generation of a secondary waste (condensed water). Because the high-performance APCS can generally control pollutant emissions to levels well below expected emission limits, the cost of retention tanks for holding offgas long enough to ensure that noncompliant offgas is not emitted cannot be technically justified.

Process simulation results also identified several issues in addition to mercury control that should be considered in future APCS design and evaluations for existing or new facilities. These include (a) incompatibility of reheat needed to prevent moisture condensation and maximum recommended carbon adsorber operating temperatures, (b) optimization of prefilter, high efficiency particulate-air (HEPA) filter, and carbon bed media replacement frequency, (c) offgas subcooling to minimize water usage, lower moisture dewpoint, and lower offgas temperature, (d) optimization of dioxin/furan control, (e) optimization of secondary waste volume and properties, $(f)$ validation of assumptions for particulate matter size distribution and control, and (g) validation of metals partitioning and control.

The engineering approach and ASPEN PLUS modeling tool developed and used in this study identified APC equipment and system performance, size, cost, and other issues that are not yet resolved. These issues need to be addressed in feasibility studies and conceptual designs for new facilities or for determining how to modify existing facilities to meet expected emission limits. The ASPEN PLUS process simulation with current and refined input assumptions and calculations can be used to provide system performance information for decision-making, identifying best options, estimating costs, reducing the potential for emission violations, providing information needed for waste flow analysis, incorporating new APCS technologies in existing designs, evaluating vendor proposals, or performing facility design and permitting activities. 


\section{CONTENTS}

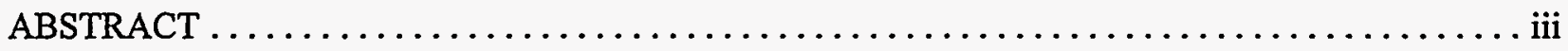

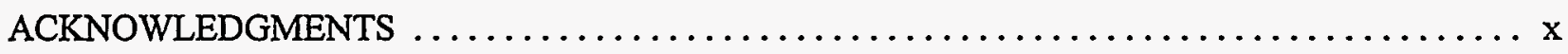

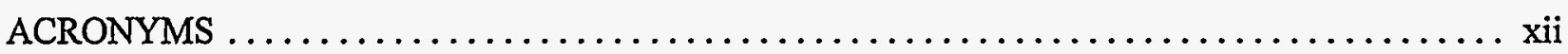

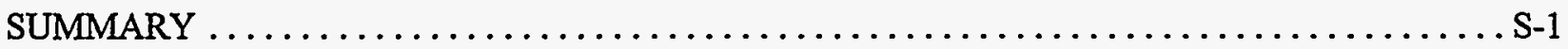

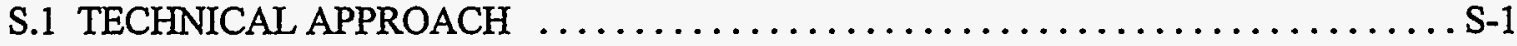

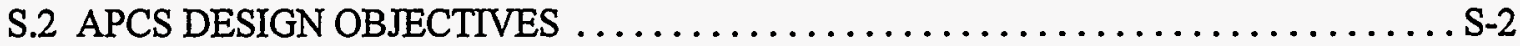

S.3 INPUT OFFGAS FLOWRATES AND COMPOSITIONS $\ldots \ldots \ldots \ldots \ldots \ldots \ldots \ldots$.

S.4 HIGH-PERFORMANCE OFFGAS SYSTEMDESIGNS $\ldots \ldots \ldots \ldots \ldots \ldots \ldots \ldots$.

S.5 APCS SIMULATION USING ASPEN PLUS $\ldots \ldots \ldots \ldots \ldots \ldots \ldots \ldots \ldots \ldots \ldots \ldots$

S. 6 MODEL RESULTS AND APCS PROCESS EVALUATION $\ldots \ldots \ldots \ldots \ldots \ldots \ldots . .5$

S.6.1 Material and Energy Balances ............................

S.6.2 Metals, Total Particulate, and $\mathrm{HCl}$ Removal . . . . . . . . . . . . . . . . S-6

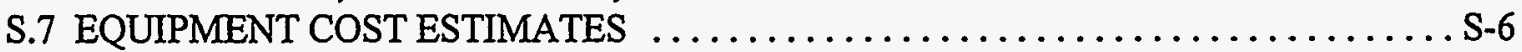

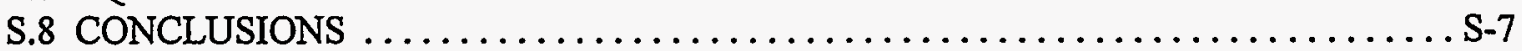

S.8.1 APCS Design and Emissions Control Performance $\ldots \ldots \ldots \ldots \ldots \ldots \ldots$. $\ldots$.7

S.8.2 APCS Process Simulation Model $\ldots \ldots \ldots \ldots \ldots \ldots \ldots \ldots \ldots \ldots \ldots$ S-8

S.8.3 Installed Capital Cost Estimates $\ldots \ldots \ldots \ldots \ldots \ldots \ldots \ldots \ldots \ldots \ldots \ldots \ldots$ S-8

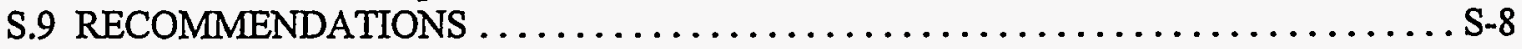

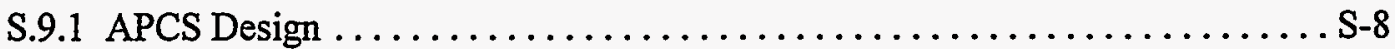

S.9.2 Uses of the APCS Process Simulation ....................

S.9.3 Control Technology Improvement and Validation $\ldots \ldots \ldots \ldots \ldots \ldots \ldots$ S-10

1. INTRODUCTION $\ldots \ldots \ldots \ldots \ldots \ldots \ldots \ldots \ldots \ldots \ldots \ldots \ldots \ldots \ldots \ldots \ldots \ldots \ldots \ldots \ldots \ldots \ldots 1-1$

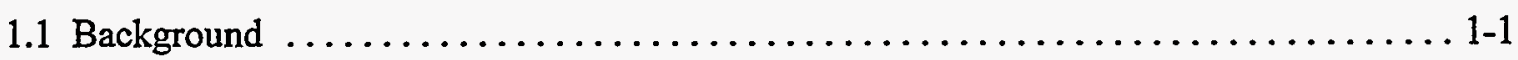

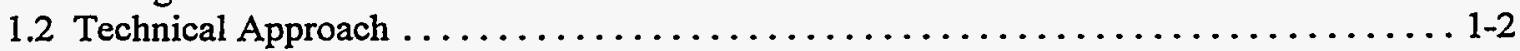

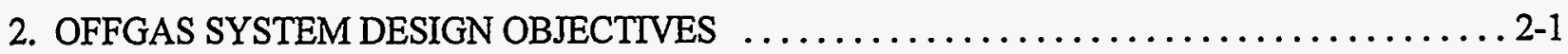

3. INPUT OFFGAS FLOWRATES AND COMPOSITIONS $\ldots \ldots \ldots \ldots \ldots \ldots \ldots \ldots \ldots \ldots \ldots .1$

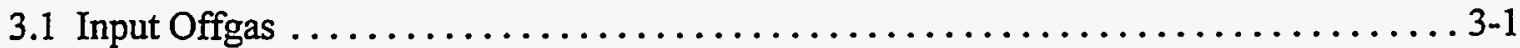

3.2 Input Volatilized and Condensed Particulate Matter $\ldots \ldots \ldots \ldots \ldots \ldots \ldots \ldots \ldots \ldots$

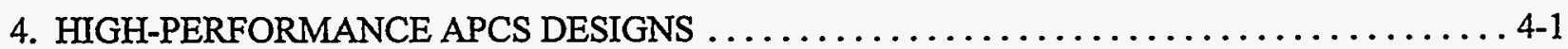

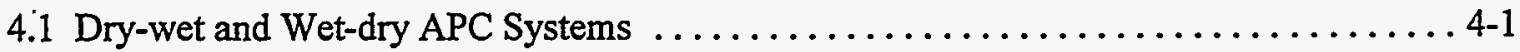

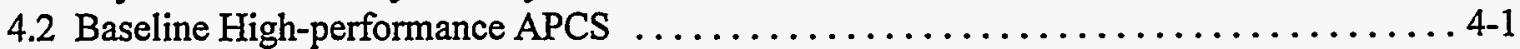

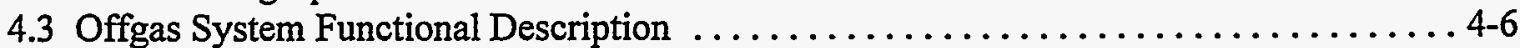

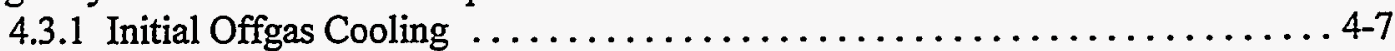

4.3.2 Particulate, Toxic Metals, and Radionuclide Control .............. 4-7

4.3 .3 Acid Gas Control ............................. 4-10

4.3.4 Mercury and Trace Organics Control ................... 4-10

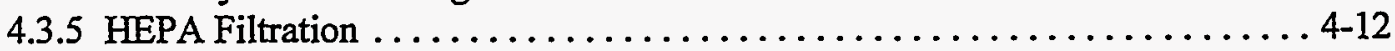

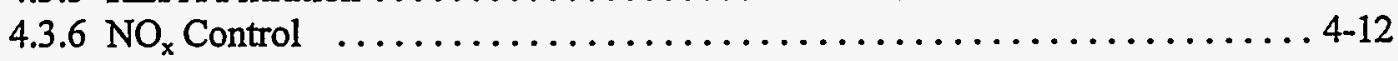


4.3.7 Continuous Monitoring $\ldots \ldots \ldots \ldots \ldots \ldots \ldots \ldots \ldots \ldots \ldots \ldots \ldots, 14$

4.3.8 Zero Emissions Approach $\ldots \ldots \ldots \ldots \ldots \ldots \ldots \ldots \ldots \ldots \ldots \ldots \ldots \ldots \ldots \ldots \ldots \ldots, 14$

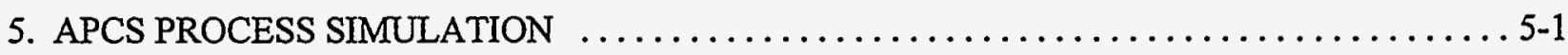

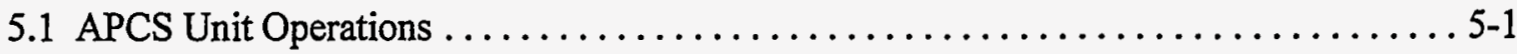

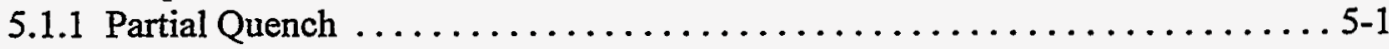

5.1 .2 Baghouse $\ldots \ldots \ldots \ldots \ldots \ldots \ldots \ldots \ldots \ldots \ldots \ldots \ldots \ldots \ldots \ldots, 5,1$

5.1 .3 Full Quench $\ldots \ldots \ldots \ldots \ldots \ldots \ldots \ldots \ldots \ldots \ldots \ldots \ldots \ldots \ldots \ldots, 5,1$

5.1 .4 Free-jet Scrubber $\ldots \ldots \ldots \ldots \ldots \ldots \ldots \ldots \ldots \ldots \ldots \ldots \ldots \ldots \ldots \ldots \ldots \ldots \ldots \ldots \ldots \ldots \ldots \ldots, 2$

5.1 .5 Offgas Reheat $\ldots \ldots \ldots \ldots \ldots \ldots \ldots \ldots \ldots \ldots \ldots \ldots \ldots \ldots \ldots \ldots \ldots \ldots \ldots \ldots \ldots \ldots \ldots, 2$

5.1 .6 Prefilter $\ldots \ldots \ldots \ldots \ldots \ldots \ldots \ldots \ldots \ldots \ldots \ldots \ldots \ldots \ldots \ldots \ldots \ldots \ldots \ldots \ldots \ldots \ldots \ldots, 3$

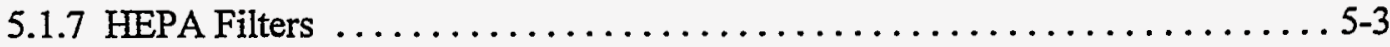

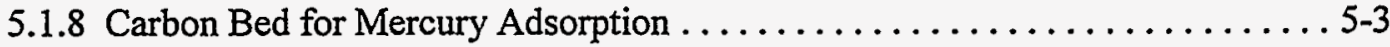

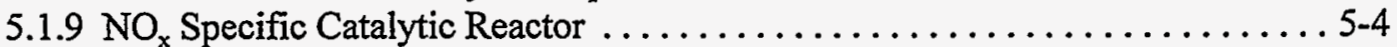

5.1 .10 Offgas Cooling and Condensation $\ldots \ldots \ldots \ldots \ldots \ldots \ldots \ldots \ldots \ldots \ldots \ldots \ldots \ldots, 4$

5.2 Thermodynamic Chemical Equilibria Calculations $\ldots \ldots \ldots \ldots \ldots \ldots \ldots \ldots \ldots, 4$

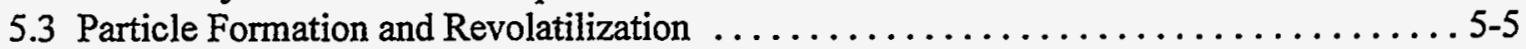

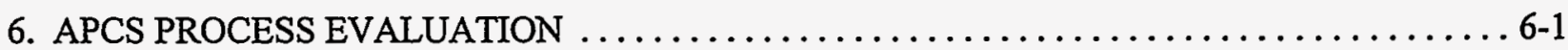

6.1 Mass and Energy Balances $\ldots \ldots \ldots \ldots \ldots \ldots \ldots \ldots \ldots \ldots \ldots \ldots \ldots, 6,1$

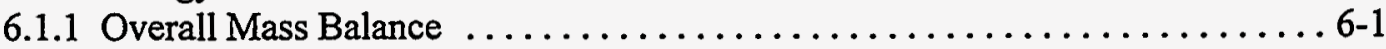

6.1.2 Elemental and Particulate Mass Balances $\ldots \ldots \ldots \ldots \ldots \ldots \ldots \ldots \ldots, 6.1$

6.1 .3 Energy Balances $\ldots \ldots \ldots \ldots \ldots \ldots \ldots \ldots \ldots \ldots \ldots \ldots \ldots, 6,6$

6.1.4 Secondary Waste Streams $\ldots \ldots \ldots \ldots \ldots \ldots \ldots \ldots \ldots \ldots \ldots \ldots, 6,8$

6.2 APCS Equipment Evaluations $\ldots \ldots \ldots \ldots \ldots \ldots \ldots \ldots \ldots \ldots \ldots \ldots \ldots, 6,10$

6.2.1 Partial and Total Quench Towers $\ldots \ldots \ldots \ldots \ldots \ldots \ldots \ldots \ldots \ldots, 6-10$

6.2 .2 Baghouse $\ldots \ldots \ldots \ldots \ldots \ldots \ldots \ldots \ldots \ldots \ldots \ldots \ldots \ldots \ldots, 6,10$

6.2 .3 Wet Scrubber $\ldots \ldots \ldots \ldots \ldots \ldots \ldots \ldots \ldots \ldots \ldots \ldots \ldots \ldots \ldots \ldots, 6,10$

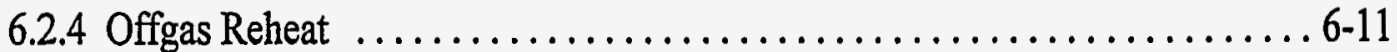

6.2 .5 Offgas Retention Tanks $\ldots \ldots \ldots \ldots \ldots \ldots \ldots \ldots \ldots \ldots \ldots \ldots \ldots, 6,11$

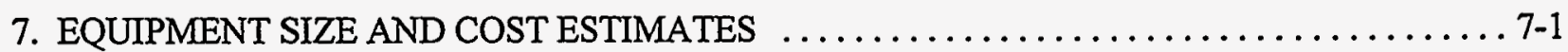

7.1 Equipment Sizing $\ldots \ldots \ldots \ldots \ldots \ldots \ldots \ldots \ldots \ldots \ldots \ldots \ldots \ldots \ldots \ldots \ldots \ldots \ldots \ldots \ldots \ldots, 3$

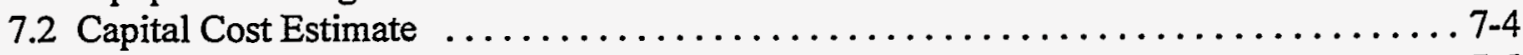

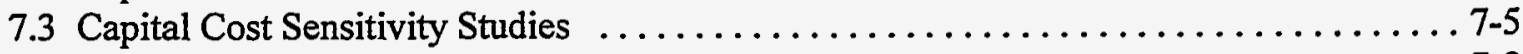

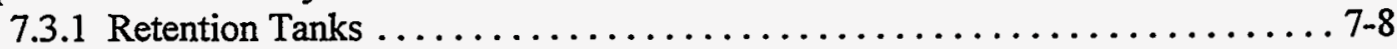

7.3.2 Selective Catalytic Reduction $\mathrm{NO}_{\mathrm{x}}$ Control $\ldots \ldots \ldots \ldots \ldots \ldots \ldots \ldots \ldots \ldots \ldots \ldots \ldots$

7.3.3 Carbon Bed Adsorbers for Mercury Removal ................. 7-10

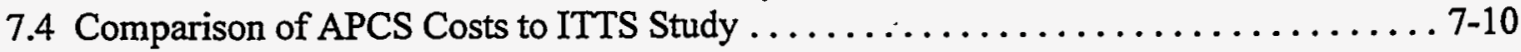

8. CONCLUSIONS AND RECOMMENDATIONS $\ldots \ldots \ldots \ldots \ldots \ldots \ldots \ldots \ldots \ldots \ldots, 8,1$

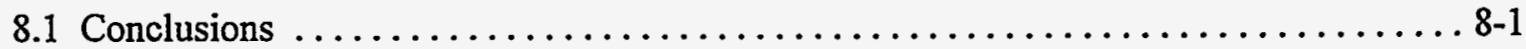

8.1.1 APCS Design and Emissions Control Performance $\ldots \ldots \ldots \ldots \ldots \ldots \ldots .6$. 1

8.1.2 APCS Process Simulation Model $\ldots \ldots \ldots \ldots \ldots \ldots \ldots \ldots \ldots \ldots, 8,1$

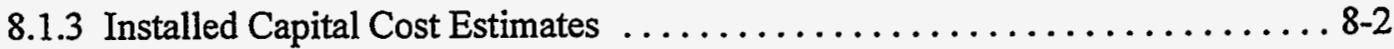

8.2 Recommendations $\ldots \ldots \ldots \ldots \ldots \ldots \ldots \ldots \ldots \ldots \ldots \ldots \ldots, \ldots, \ldots \ldots \ldots, 2$

8.2 .1 APCS Design $\ldots \ldots \ldots \ldots \ldots \ldots \ldots \ldots \ldots \ldots \ldots \ldots \ldots \ldots \ldots \ldots, 8,2$

8.2.2 Uses of the APCS Process Simulation $\ldots \ldots \ldots \ldots \ldots \ldots \ldots \ldots \ldots .8,3$ 
APPENDIX A-Offgas Flowrates and Compositions for the Offgas System Conceptual Design and Evaluation Project.

\section{FIGURES}

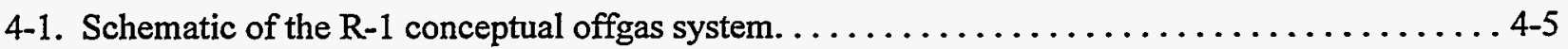

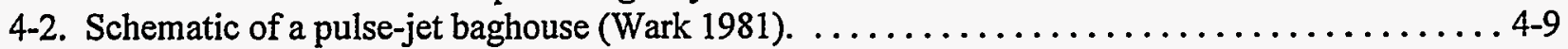

4-3. Schematic of free-jet scrubber. ................................ 41

4-4. Offgas containment housing consisting of HEPA prefilter, HEPA filters, and carbon beds with

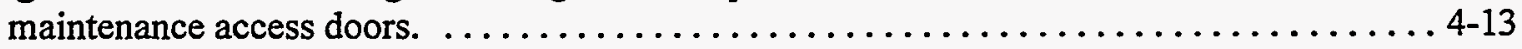

6-1. APCS process simulation flowsheet for the high-flow case. $\ldots \ldots \ldots \ldots \ldots \ldots \ldots \ldots \ldots \ldots 6$

6-2. APCS process simulation flowsheet for the low-flow case. $\ldots \ldots \ldots \ldots \ldots \ldots \ldots \ldots \ldots \ldots, 6 \ldots \ldots$

7-1. Breakdown of purchased equipment cost by major process units of the APCS. . . . . . . . 7-6

7-2. Breakdown of factors that determine total capital cost. $\ldots \ldots \ldots \ldots \ldots \ldots \ldots \ldots \ldots \ldots 7$

7-3. Increased capital cost from the use of retention tanks. . . . . . . . . . . . . . . . . $7-9$

7-4. Comparison of the cost of evacuated and pressurized retention tanks. . . . . . . . . . . . .

7-5. Comparison of the cost for the complete APCS to the cost without $\mathrm{NO}_{x}$ control and without carbon

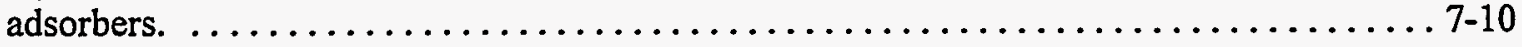

\section{TABLES}

2-1. Design objectives for mixed waste treatment offgas control systems. $\ldots \ldots \ldots \ldots \ldots \ldots \ldots 2$

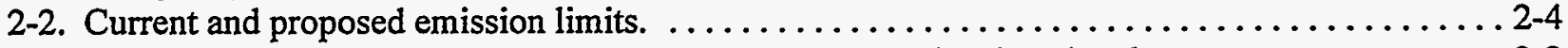

3-1. Input offgas conditions at the outlet of the secondary combustion chamber. $\ldots \ldots \ldots \ldots \ldots \ldots 3-2$

3-2. Input volatilized and entrained metals at the outlet of the secondary combustion chamber. . . . . 3-4 3-3. Flowrates and compositions of the particulate matter at the outlet of the secondary combustion

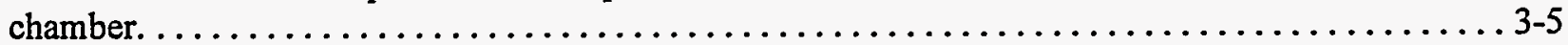
4-1. APCS designs from the ITTS study and the IWPF project. $\ldots \ldots \ldots \ldots \ldots \ldots \ldots \ldots \ldots \ldots .2$

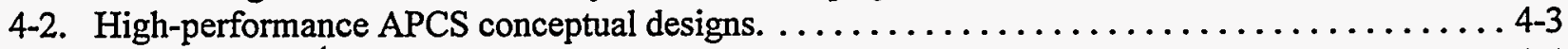

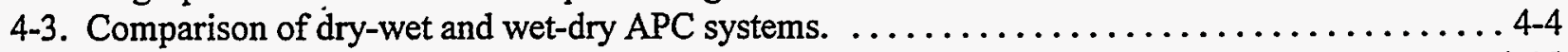

4-4. Continuous emissions monitoring for the high-performance offgas systems. $\ldots \ldots \ldots \ldots, 4-15$

6-1. Mass balance in the APCS of the high-flow and low-flow cases. $\ldots \ldots \ldots \ldots \ldots \ldots \ldots \ldots 6$

6-2. Decontamination factors for elemental metals and total PM. . . . . . . . . . . . .

6-3. Comparison of estimated emission concentrations to emission limits. . . . . . . . . . . 6-7

6-4. Masses and volumes of secondary wastes generated (high-flow case). . . . . . . . . . . 6-9

6-5. Masses and volumes of secondary wastes generated (low-flow case) . . . . . . . . . . . 6-9

7-1. Capital costs $(\$ 1,000)$ for conceptual APCS alternatives. ................... 


\section{ACKNOWLEDGMENTS}

This report was prepared by the Lockheed Martin Idaho Technologies Company (LMITCO) Technology Deployment Center for the DOE Office of Science and Technology (OST), as part of Integrated Process Analysis studies directed by Carl Cooley of DOE OST. The study was conducted with technical collaboration from CEntry Constructors and Engineers (Salt Lake City, UT), IT Corporation (Knoxville, TN), and Energy and Environmental Research Corporation (Irvine, CA). 


\section{ACRONYMS}

\begin{tabular}{|c|c|}
\hline ALARA & As Low As Reasonably Achievable \\
\hline APC & air pollution control \\
\hline APCS & air pollution control system \\
\hline ARAR & applicable or relevant and appropriate requirement \\
\hline BIF & Boilers and Industrial Furnaces \\
\hline CERCLA & Comprehensive Environmental Response, Compensation, and Liability Act \\
\hline CFR & Code of Federal Regulations \\
\hline CIF & Consolidated Incineration Facility \\
\hline CM & Construction Management \\
\hline DF & decontamination factor \\
\hline $\mathrm{D} / \mathrm{F}$ & dioxins and furans \\
\hline DOE & U.S. Department of Energy \\
\hline DRE & Destruction and Removal Efficiency \\
\hline DWPF & Defense Waste Processing Facility \\
\hline EER & Energy and Environmental Research Corporation \\
\hline EPA & U.S. Environmental Protection Agency \\
\hline HEPA & high efficiency particulate-air ... . \\
\hline HVAC & heating, ventilation, and air conditioning \\
\hline INTS & Integrated Nonthermal Treatment System \\
\hline ITTS & Integrated Thermal Treatment System \\
\hline IWPF & Idaho Waste Processing Facility \\
\hline LMITCO & Lockheed Martin Idaho Technologies Company \\
\hline LVM & low volatile metals \\
\hline MACT & Maximum Achievable Control Technology \\
\hline MEI & maximum exposed individual \\
\hline $\mathrm{M} \& \mathrm{O}$ & maintenance and operations \\
\hline MSE & Mountain States Energy \\
\hline NESHAP & National Emission Standards for Hazardous Air Pollutants \\
\hline PIC & Product of Incomplete Combustion \\
\hline POHC & Principal Organic Hazardous Constituent \\
\hline PM & particulate matter \\
\hline RCRA & Resource Conservation and Recovery Act \\
\hline $\mathrm{SCC}$ & secondary combustion chamber \\
\hline SCR & selective catalytic reduction \\
\hline SRS & Savannah River Site \\
\hline SVM & semivolatile metals \\
\hline TEQ & Toxicity Equivalent \\
\hline THC & Total Hydrocarbons \\
\hline TRU & transuranic \\
\hline TSCA & Toxic Substances Control Act \\
\hline
\end{tabular}




\section{SUMIMARY}

Thermal treatment processing of mixed waste is recognized as one of the most effective means for destroying hazardous organics, reducing waste volume, and immobilizing most hazardous metals and radionuclides. However, mixed waste thermal treatment can produce atmospheric pollutants, including particulates, radionuclides, toxic metals, dioxins and furans (D/F), and acid gases, that must be controlled to protect the public and the environment and to meet regulatory limits. New emission limits in the U.S. Environmental Protection Agency's (EPA's) proposed Maximum Achievable Control Technology (MACT) Rule are significantly more stringent than current emission limits. Current air pollution control system (APCS) configurations may require modifications to comply with the stricter proposed emission limits. Development and deployment of high-performance and reliable offgas systems are needed to improve pollutant control and address stakeholder concerns for emissions control. They may also enable less rigorous feed characterization and control, which may result in lower overall treatment costs.

This Air Pollution Control System Conceptual Design and Evaluation study was conducted to evaluate a high-performance (APC) system for minimizing air emissions from mixed waste thermal treatment systems.

\section{S.1 TECHNICAL APPROACH}

The technical approach included several separate activities. First, design objectives were identified for use in designing and evaluating alternative high-performance APCS configurations. APCS concepts were designed to meet these objectives. A representative baseline APCS was selected for detailed evaluations. The selected system included most of the key enhanced APCS features present in the other systems. Detailed evaluation of all seven alternatives was not within the scope of this study.

To focus on the emissions control functions of the APCS, the scope of the APCS designs was limited to equipment downstream of a hypothetical fully oxidizing primary thermal treatment unit (such as an incinerator) and secondary combustion chamber (SCC). Some thermal treatment approaches such as gasification produce a synthesis gas rather than a fully oxidized offgas, but only fully oxidized offgas was within the scope of this study. Therefore, the input gas to the air pollution control (APC) systems consisted of fully oxidized offgas with entrained and volatilized particulate matter (PM).

Flowrates and compositions of the offgas and PM (including entrained and volatilized metal species) entering the APCS were estimated based on a limited evaluation of SCC offgas that would be produced from treating DOE complex-wide mixed waste streams. This information was used in a process simulation model to evaluate the effectiveness of the selected APCS to achieve emission limits for selected pollutants and meet the other design objectives. The process simulation estimated the partitioning and control of PM and other pollutants and the offgas passed through each unit operation. The process simulation used equipment specifications from equipment vendors, empirical performance data, chemical reaction and phase equilibrium calculations, and engineering assumptions where necessary to perform mass and energy balances and determine the fate of offgas and pollutants. For further simplicity, the simulation did not specifically model the fate of radionuclides, although results indicate the expected fate of many volatile and nonvolatile radionuclide constituents that have properties similar to those metals that were modeled. In addition, the dioxins, furans, and other organic compounds were not specifically considered in this study. The conceptual design evaluated in this study was assumed to adequately control $\mathrm{D} / \mathrm{Fs}$ because it complied with the $\mathrm{D} / \mathrm{F}$ control specifications in the proposed MACT Rule. Other organic 
compounds were considered to be adequately controlled in the upstream primary treatment unit and SCC, which were not included in the scope of this study.

Installed capital costs were estimated for two different cases. Sensitivity studies were also conducted to evaluate the incremental cost and benefit of added carbon adsorber beds for mercury control, specific catalytic reduction for $\mathrm{NO}_{x}$ control, and offgas retention tanks for holding the offgas until sample analysis is conducted to verify that the offgas meets emission limits. Operating costs were not included in the scope of this study.

\section{S.2 APCS DESIGN OBJECTIVES}

APCS design objectives for mixed waste thermal treatment and offgas systems have been identified in this study. The most important design objectives considered during the study included:

- $\quad$ Reduce emissions of gaseous organics, radionuclides, toxic metals, particulate, and acid gases to meet expected regulatory limits

- Avoid a nuclear criticality condition

- Have system capability to accept wide variations in offgas flowrate and composition entering the APCS without upsets or degradation of performance beyond acceptable limits

- Operate with minimal downtime

- $\quad$ Comply with As Low As Reasonably Achievable (ALARA) objectives

- Minimize secondary streams and maximize ease of secondary stream treatment and disposal

- Minimize total treatment facility life-cycle cost.

\section{S.3 INPUT OFFGAS FLOWRATES AND COMPOSITIONS}

An evaluation was conducted using available data to estimate representative thermal treatment offgas flowrates and compositions, including flowrates, particle size, and compositions of PM and metal species that enter the APCS from the primary thermal treatment unit and the SCC. This evaluation established minimum, normal, and maximum offgas flowrates and compositions, and PM/metals data for two separate thermal treatment cases. These cases included a relatively high offgas flowrate (high-flow) case resulting from assuming standard fuel-fired, air combustion thermal treatment (i.e., rotary kiln with a $\mathrm{SCC}$ ) and a lower offgas flowrate (low-flow) case resulting from assuming a thermal treatment unit that uses electrical heat generation and oxygen combustion (i.e., plasma arc furnace with a SCC).

The maximum input offgas and PM flowrates and average compositions were generally used in this study. This provided a degree of conservatism, biasing the APCS size and cost estimates and estimates of secondary product streams conservatively high. For additional conservatism, maximum concentration values for ppm-level pollutant species (sulfur dioxide, nitrogen oxides, total chlorine) were used. The total PM was defined to include all of the metal species that can typically comprise fly ash or offgas solids entrained or volatilized in the offgas. Eleven metals were specifically modeled because they 
are considered hazardous and are found in the waste based on available composition information. These metals were mercury, lead, cadmium, arsenic, beryllium, chromium, antimony, barium, selenium, silver, and tantalum. The bulk of the total PM includes other common metal and nonmetal species that were not specifically modeled, such as oxides of aluminum, iron, and silicon. The partitioning of specific radionuclides was not modeled at this time.

The flowrates and concentrations for the key metals in the input offgas stream were determined based on known or assumed maximum concentrations of the metals in the waste feed, waste feedrate to the primary treatment system, and chemical equilibrium calculations at thermal treatment operating conditions. Entrained particulate was assumed to be $10 \%$ of the total waste feedrate into the primary treatment system for both offgas cases. This level of PM entrainment was based on results of several different DOEsponsored test programs and other estimates. Previous studies were also used to estimate the particle size distribution of the entrained particulate in the offgas entering the APCS. The entrained PM was assumed to be $40-60$ weight \% greater than $0.5 \mu \mathrm{m}$ for the low-flow and high-flow cases. All of the PM formed in the APCS from condensed volatile matter was conservatively assumed to be less than $0.5 \mu \mathrm{m}$. The total $\mathrm{PM}$ in both cases, which includes entrained particulate and vapor-phase metal species at $2,200^{\circ} \mathrm{F}$, was approximately $15 \%$ of the treatment system waste input feedrate. This total PM carryover value is conservatively high because measurements from past mixed waste demonstration tests have shown total carryover values of $1-10 \%$ of the waste input feedrate.

\section{S.4 HIGH-PERFORMANCE OFFGAS SYSTEM DESIGNS}

Seven high-performance offgas system designs were conceptualized for evaluation in this study. These systems all meet or exceed the APCS design objectives listed earlier by using redundant, oversized, or backup conventional control technologies, innovative systems such as no release, low-release, or delayed release systems, or various combinations of traditional and innovative designs. These systems are generally based on earlier Integrated Thermal Treatment Systems (ITTS) and Idaho Waste Processing Facility (IWPF) conceptual designs, but include various above-listed features that enhance control performance.

A baseline high-performance offgas system (R-1) was selected for process simulation in this study. This system is generally representative of the others. This system consists of evaporative water coolers, a dry baghouse, free-jet scrubber with two-stage phase separation, hot air reheater, prefilter, two-stage high efficiency particulate-air (HEPA) filters, sulfur-impregnated carbon adsorbers, selective catalytic reduction (SCR) for $\mathrm{NO}_{x}$ control, and optional offgas retention. This system is similar to the ITTS A-1 offgas system except for the placement of HEPAs and carbon filters and offgas retention. This dry-wet system design is a probable candidate for deployment in mixed waste treatment because, among other reasons, it includes standard APCS equipment and less technical uncertainty in system performance. Additional features that make this system "high performance" include (a) separation of PM upstream of the wet scrubber, minimizing PM-related maintenance and deposition issues in the wet scrubber, (b) indirect offgas reheat using preheated air, (c) multiple redundancy of PM, metals, and radionuclide removal, with different units based on different control principles, (d) sulfur-impregnated carbon absorption to remove $\mathrm{Hg}$ species and also trace organics including $\mathrm{D} / \mathrm{F}$, (e) an $\mathrm{SCR}$ for $\mathrm{NO}_{\mathrm{x}}$ control, (f) a continuous emissions monitoring system (CEMS) compliant with the proposed MACT Rule, and (g) optional offgas retention tanks.

Operation of thermal and nonthermal treatment systems with "zero emissions" is not realistically possible because of effluent gases such as nitrogen and oxygen that cannot realistically be condensed. The 
most technically feasible approach for "zero emissions" is to minimize the volumes of offgas to the extent possible and then prevent the release of the offgas until it has been demonstrated that the levels of any pollutants are within regulatory limits. Methods that can be used to achieve this include:

- Oxygen instead of air for combustion

- Electrical heat input for treating low-heating-value wastes rather than fossil fuel combustion

- Water spray evaporation for cooling rather than air dilution cooling

- Offgas retention until analyses are complete

- $\mathrm{CO}_{2}$ absorption or removal via liquefaction or through photosynthesis.

All of these methods except $\mathrm{CO}_{2}$ removal were considered in this study.

\section{S.5 APCS SIMULATION USING ASPEN PLUS}

Process simulation can be used to quickly evaluate the integrated APCS performance and quantitatively demonstrate if process objectives can be expected to be achieved for a given process design. ASPEN PLUS (hereafter referred to as ASPEN) is a process simulation code that was used to calculate mass and energy balances around each unit operation of the R-1 high-performance APCS using chemical reaction and equilibrium data specified by the user or retrieved from an extensive database.

Chemical reactions were calculated based on chemical equilibria at specified temperatures or by defining the extent of reaction. The composition of most constituents were calculated using chemical equilibria at the process temperature. In some cases, nonequilibrium conditions were expected when indicated by empirical data or kinetic or mass transfer limitations. Nonequilibrium conditions in the model were accounted for by specifying an extent of reaction less than $100 \%$ (i.e., $85 \% \mathrm{NO}_{\mathrm{x}}$ reduction in SCR unit, and $99 \%$ elemental $\mathrm{Hg}$ removal in carbon bed) or by specifying a reaction temperature different from

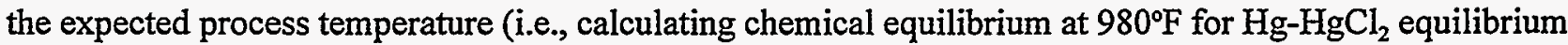
calculations, even though the offgas was cooled from $2,200^{\circ} \mathrm{F}$ to below $200^{\circ} \mathrm{F}$.

Particulate removal from the offgas by the baghouse, prefilter, and HEPA filters were simulated in ASPEN, which allows the particulate removal efficiency to be specified by the user. All removal efficiencies were defined in terms of the ability to remove particles larger than and smaller than $0.5 \mu \mathrm{m}$. Particulate removal efficiency in the scrubber was based on vendor-provided design guides that specified the PM concentration in the scrubber offgas as a function of the atomizing air and scrubber liquid mass flowrates relative to the mass flowrate of the offgas being scrubbed. Particle formation resulting from the condensation of metal vapors was also simulated in the ASPEN model. Since the homogeneous condensation of vapors can yield submicron particles, all condensed metal vapor was conservatively assumed to form particles that were less than $0.5 \mu \mathrm{m}$ in diameter. No heterogeneous condensation of vapors onto $>0.5 \mu \mathrm{m}$ particles, or growth of homogeneously condensed particles beyond $0.5 \mu \mathrm{m}$, was assumed. These assumptions challenged the capability of the APCS to capture submicron particles. 


\section{S.6 MODEL RESULTS AND APCS PROCESS EVALUATION}

The ASPEN simulation model was used to calculate the material and energy balances associated with treating two different offgas cases, to evaluate the effect of changing process variables, and to identify potential process and design limitations in the APCS.

\section{S.6.1 Material and Energy Balances}

The design and operation of the dry-wet R-1 APCS results in several material/energy balance findings. While the offgas is efficiently cleaned of contaminants, the offgas mass flowrate at the stack increased by more than $100 \%$ over the APCS inlet offgas flowrate. Roughly half of the increase was from quench water evaporated into the offgas. The other half was from scrubber atomizing air and preheated air used to reheat the saturated scrubber outlet offgas.

The secondary waste streams generated in the baseline APCS models (not including the offgas retention option) consist primarily of the PM collected in the baghouse, and the scrub solution discharge containing dissolved salts and trace amounts of PM. Most of the PM was captured in the baghouse. The scrub solution discharge represents the largest volume secondary waste stream and the greatest disposal challenge. The scrub solution discharge was significantly greater in the low-flow case where the assumption of more hydrogen chloride in the offgas entering the APCS resulted in more dissolved salts. In this case, there was such a high level of dissolved salts that a large amount of scrub solution makeup water was necessary to dilute the dissolved salt concentration to the maximum acceptable limit of $10 \mathrm{wt} \%$.

Other secondary wastes that were generated were spent baghouse bags, prefilters, HEPA filters, and carbon bed media. The replacement frequency for these materials depends on the operating conditions as well as total particulate and mercury concentrations in the offgas. HEPA filter and prefilter replacement frequency for the low-flow case was greater than for the high-flow case primarily because only 12 HEPA filters (instead of 24 filters for the air-combustion case) were used in parallel to process approximately the same particulate mass flowrate. While the HEPA filter replacement frequency was acceptably low at 340 to $>4,000$ operating hours, prefilter replacements were too frequent for both cases (13-31 operating hours). This high replacement frequency could be extended by using less conservative PM loading assumptions, higher efficiency baghouse filters, prefilters with lower removal efficiency and greater loading capacity, or cleanable prefilters. The prefilter efficiency should be optimized to maximize the operating time for the prefilters without causing undesirably high frequency HEPA filter replacements.

Carbon bed replacement frequency was determined based on the mass flowrate of mercury entering the carbon bed adsorbers and a conservative vendor-recommended mercury loading of $20 \mathrm{wt} \%$ on the carbon. The service life would increase if the maximum $\mathrm{Hg}$ feedrate was significantly decreased or more $\mathrm{Hg}$ was oxidized to water-soluble mercury chloride (which is assumed in this model to be removed with high efficiency in the upstream wet scrubber).

Energy balances were performed to calculate the amount of energy required to cool or heat a number of gas or liquid streams in the APCS. In the low-flow case, model simulations indicated an issue that needs to be resolved to prevent moisture condensation in HEPA filters while allowing reasonably lowtemperature carbon bed operation. The moisture-saturated scrubber offgas temperature was only increased from $181^{\circ} \mathrm{F}$ (scrubber operating temperature) to $195^{\circ} \mathrm{F}$ (maximum allowable temperature for carbon beds). Moisture-saturated offgas is generally heated at least $40^{\circ} \mathrm{F}$ above the dewpoint to prevent moisture 
condensation in downstream HEPA filters and carbon beds. The $14^{\circ} \mathrm{F}$ differential may be insufficient to prevent such condensation from occurring. A possible remedy to achieve sufficient offgas cooling before the reheater may be to introduce additional cold water in the full quench tower, and discharging the heated water from the full quench tower to waste water treatment or to a chiller that removes heat from the system and allows recycling of the quench water.

The greatest energy requirements occurred when the optional offgas retention was included. The offgas was cooled to a design temperature of $100^{\circ} \mathrm{F}$ upstream of the retention tanks to reduce the necessary capacity for the tanks and to reduce moisture condensation in the tanks. This requirement results in a large quantity of water condensate being removed from the gas. In both cases, water condensate is generated at a rate of approximately $25 \mathrm{gpm}$, which is at least 2.5 times higher than the scrub solution discharge rates for each case. The total heat removed was $19 \times 10^{6} \mathrm{BTU} / \mathrm{hr}$ and $17 \times 10^{6} \mathrm{BTU} / \mathrm{hr}$ for the high-flow and low-flow cases, respectively.

\section{S.6.2 Metals, Total Particulate, and HCI Removal}

Variations in the particle size distribution of offgas particulate within the limited ranges of this study had almost no effect on the total particulate mass captured in the baghouse. The presence of the baghouse upstream of the wet scrubber improves the performance of the entire offgas system by minimizing problems associated with particulate in the scrub solution such as sludge deposition, particle re-entrainment, and spray nozzle erosion. The primary purpose of the wet scrubber is the removal of acid gases and soluble salts. Additional particulate removal occurred in the scrubber although it was over 20 times less efficient than the baghouse.

The decontamination factors (DFs) for all metals except mercury were on the order of $10^{9}$. Such high DFs were attributed to the cumulative effects of the baghouse (DF $=100-217)$, the scrubber (DF = 1-340), the prefilter (3.88), and double HEPA filters ( $D F=1,000$ for each filter). Calculated emission concentrations for particulate matter and volatile metals were 4-5 orders of magnitude lower than current or proposed limits. Predicted hydrogen chloride concentrations were approximately $1 / 2$ of (or less than) proposed limits.

At a $\mathrm{Hg}$ feedrate of $10.74 \mathrm{lb} / \mathrm{hr}$, the total $\mathrm{Hg}$ emission rates from the APCS for the high-flow and low-flow cases were 2,645 and $25 \mu \mathrm{g} / \mathrm{dscm}$, respectively, compared to the proposed limit of $40 \mu \mathrm{g} / \mathrm{dscm}$. The large difference, and failure to meet $\mathrm{Hg}$ emission limits for the high-flow case, was a function of the relative $\mathrm{Cl}: \mathrm{Hg}$ ratios. The low-flow case also included maximum $\mathrm{Cl}$ input. The elevated $\mathrm{Cl}: \mathrm{Hg}$ ratio in the offgas entering the APCS increased the oxidation of elemental $\mathrm{Hg}$ to the more water-soluble $\mathrm{Hg}(\mathrm{II})$ chloride. The water-soluble mercury was more easily captured in the wet scrubber than was elemental Hg. These results suggest that for moderate $\mathrm{Cl}: \mathrm{Hg}$ ratios, the $\mathrm{Hg}$-adsorbing efficiency of the carbon beds needs to be increased at least two orders of magnitude higher ( $99.99 \%$ instead of $99 \%)$ to ensure that $\mathrm{Hg}$ emission limits do not exceed the proposed limits. Such a high adsorption efficiency for carbon beds was not supported by vendor information. A more practical option may be to limit the maximum allowable mercury feed rate to around $0.1 \mathrm{lb} / \mathrm{hr}$, while using carbon beds with removal efficiencies of $99 \%$.

\section{S.7 EQUIPIMENT COST ESTIMATES}

The installed capital costs for the offgas systems for the two cases were estimated using ASPEN model results, vendor-provided purchase costs, equipment estimates, and installation cost factors. The 
installed APCS total capital cost for the high-flow case was $\$ 46$ million and the installed APCS cost for the low-flow case was $\$ 27$ million.

These costs do not include the cost for retention tanks and associated equipment that would be used to retain the offgas exiting the APCS for analysis. There were two variations of retention tanks that were considered-evacuated retention tanks that operate under slightly negative pressure when at full capacity, and retention tanks that are pressurized up to $100 \mathrm{psig}$ when full. The addition of the evacuated retention tanks and associated equipment increased the cost of the APCS for the high-flow case to $\$ 831$ million. The total installed cost including evacuated retention tanks for the low-flow case increased to $\$ 426$ million. The total capital costs for the high-flow and low-flow cases using pressurized retention tanks were $\$ 374$ million and $\$ 167$ million, respectively.

Excluding the offgas retention tanks and associated equipment, the most expensive APC unit was the carbon adsorber bed, followed by the $\mathrm{NO}_{x}$ control unit and the HEPA filters.

\section{S.8 CONCLUSIONS}

This study has utilized a process simulation approach to evaluate a high-performance APCS design. The study included identification of several high performance APCS designs, selection of a design for process simulation, computations of APCS performance for controlling pollutants that could be emitted in offgas produced from DOE mixed waste thermal treatment, installed capital cost estimates, and identification of potential limitations and outstanding issues of the process simulation, assumptions, and APCS performance.

\section{S.8.1 APCS Design and Emissions Control Performance}

- The selected high-performance APCS design easily meets expected stringent emission limits for all pollutants, except possibly mercury.

- The offgas concentrations of PM and selected metals were reduced to $10^{-1}-10^{-4}$ of current or proposed limits. This represents a significant safety factor below expected limits for these pollutants. $\mathrm{HCl}$ and $\mathrm{Cl}_{2}$ concentrations were approximately $1 / 2$ of or less than proposed limits.

- While the offgas concentration of $\mathrm{Hg}$ was around $2 / 3$ of the expected limit for the low-flow case, it was over 60 times greater than the limit for the high-flow case. The lower $\mathrm{Hg}$ emissions in the low-flow case resulted from the removal of greater quantities of water-soluble $\mathrm{HgCl}_{2}$ in the wet scrubber. Performance of $\mathrm{Hg}$ control technologies including sulfur-impregnated carbon absorption must be improved and validated to provide the level of $\mathrm{Hg}$ control (at least 99.99\%) needed if some Hg-contaminated mixed wastes are thermally treated. If such high $\mathrm{Hg}$ control efficiencies are not possible, then the $\mathrm{Hg}$ content in waste fed to mixed waste incinerators may need to be significantly limited to meet expected emission limits.

- Decontamination factors (DFs) for all semivolatile and low volatile metals except mercury for both offgas cases were on the order of $10^{9}$. Mercury DFs in the high-flow and low-flow cases were only 130 and 34,000, respectively. The higher Hg DF in the low-flow case was attributed to a higher $\mathrm{HCl}$ concentration in the offgas to form more water soluble $\mathrm{HgCl}_{2}$ which was readily removed in the wet scrubber. 


\section{S.8.2 APCS Process Simulation Model}

- ASPEN PLUS is a powerful process simulation tool that was used to evaluate the effectiveness of an integrated APCS to minimize pollutant emissions as a function of offgas flowrates, initial pollutant concentrations, and the APCS unit operations and their operating parameters.

- The process simulation helped to identify potential system design limitations such as limited $\mathrm{Hg}$ control efficiency, insufficient offgas cooling in the low-flow case to allow adequate offgas reheat, and high frequency HEPA prefilter replacements.

Several simplifying steps and assumptions were used in this study. These included (a) exclusion of upfront thermal treatment steps including primary thermal treatment and secondary combustion, (b) the use of only fully oxidized input offgas from a hypothetical SCC, (c) exclusion of specific radionuclides, products of incomplete combustion, and $\mathrm{D} / \mathrm{F},(\mathrm{d})$ simplification and limited range of offgas and PM flowrate and composition, and PM size distributions, (e) exclusion of secondary waste treatment options and systems, $(f)$ use of sometimes unproven vendor recommendations and assumptions for control equipment performance, $(\mathrm{g})$ lack of optimization of some model results such as $\mathrm{Hg}$ control efficiency, secondary waste generation, offgas cooling, reheat, and carbon adsorber temperature limits, and $(\mathrm{h})$ the use of cost factors for estimating installed capital costs.

\section{S.8.3 Installed Capital Cost Estimates}

- The installed capital costs of the APCS for the high-flow and low-flow cases were estimated to be $\$ 46$ million and $\$ 27$ million, respectively. These installed capital costs are 6 times higher than the major and other equipment purchase costs, largely because of large factors needed to account for costs associated with designing, constructing, and permitting DOE facilities (facility capital costs).

- The addition of retention tanks and associated equipment is prohibitively costly. The total estimated APCS costs for the high-flow and low-flow cases using pressurized retention tanks was $\$ 374$ million and $\$ 160$ million, respectively. The total estimated APCS costs for the high-flow and low-flow cases using evacuated retention tanks was $\$ 831$ million and $\$ 426$ million, respectively.

- Not including offgas retention tanks, the most costly control equipment was the carbon adsorbers followed by the $\mathrm{NO}_{x}$ control unit and HEPA filters.

\section{S.9 RECOMMENDATIONS}

Several recommendations result from this study. These include recommendations for future APCS design, uses of the APCS process simulation developed in this study, and validation or improved performance of specific control technologies.

\section{S.9.1 APCS Design}

- Future APCS design for new facilities or for modifying existing facilities should consider the features of the high-performance APCS modeled in this study to provide greatest assurance of adequate emissions control. 
- Offgas retention tanks for holding offgas long enough to ensure that noncompliant offgas is not emitted are not recommended. Instead, efforts should emphasize proper APCS design, installation, and operation to achieve compliance goals without the use of offgas retention and delayed offgas release.

- $\quad$ Significant issues identified in this study that should be addressed in future APCS designs include (a) Hg control technology capabilities and limitations, (b) optimization of offgas cooling, reheat, and carbon adsorber temperature to prevent moisture condensation in HEPAs and downstream equipment while achieving desired $\mathrm{Hg}$ removal efficiency and minimizing secondary wastes, (c) optimization of prefilter, HEPA filter, and carbon bed media replacement frequency, (d) optimization of D/F control, (e) optimization of secondary waste volume and properties, $(f)$ the impact that secondary waste treatment has on system alternatives, $(\mathrm{g})$ validation of assumptions for PM size distribution and control, and (h) validation of metals partitioning and control.

\section{S.9.2 Uses of the APCS Process Simulation}

- The engineering analysis approach, including the process simulation model, established in this study should be used to evaluate additional high-performance APC systems proposed for new facilities or as modifications to existing facilities. This process simulation model can be used in feasibility studies, preconceptual and conceptual designs, technology development and validation programs, and to support higher-level waste flow analyses.

- Using this process simulation can help provide (a) better information for decisions about alternatives for existing mixed waste treatment facilities to comply with new regulations, (b) better identification and qualification of incomplete performance and cost information for new or existing technologies, (c) better public, regulatory, and stakeholder acceptance of thermal treatment and APC systems based on more definitive performance evaluations, (d) avoidance of costly and unnecessary features such as offgas retention, and (e) more rapid and less costly implementation of new facilities and needed modifications to existing treatment facilities.

- Parametric studies should be conducted to identify the impact of variations in offgas or waste feed conditions, new APCS equipment such as improved $\mathrm{Hg}$ control technologies, improved or validated control equipment performance data, and operating parameters on pollutant emissions and life-cycle costs for a given APCS. Parametric studies should also be conducted to optimize $\mathrm{Hg}$ control efficiency, secondary waste generation, offgas cooling, reheat, and carbon adsorber temperatures, and APCS costs.

The process simulation should be upgraded to include (a) upstream thermal treatment steps such as primary thermal treatment and secondary combustion so the process simulation can determine species partitioning and offgas generation from the thermal treatment system as functions of the waste feed content and thermal treatment equipment design and operation, (b) modeling of specific radionuclides, products of incomplete combustion, and $\mathrm{D} / \mathrm{F}$, and (c) downstream secondary waste treatment and disposition options. Inclusion of upstream and downstream processes in the entire system would evolve this APCS simulation into a complete simulation of the entire treatment system. This would provide better identification of any issues that could impact different unit operations in the entire system, and enable optimization of the entire system to meet system objectives. 
- A process simulation of candidate wet-dry high-performance APCS designs should be done to better identify and quantify advantages, disadvantages, and issues for wet-dry systems as compared to the dry-wet system modeled in this study.

- Cost estimates should be upgraded to focus on lifecycle costs which include capital costs and operating costs over some facility lifecycle.

\section{S.9.3 Control Technology Improvement and Validation}

- Existing and new $\mathrm{Hg}$ control technologies need to be improved and validated to provide assurance that mixed waste thermal treatment facilities can meet expected $\mathrm{Hg}$ emission limits while processing some $\mathrm{Hg}$-containing mixed waste streams. If such validation is not possible, then restrictive $\mathrm{Hg}$ feed limits (and feed characterization for $\mathrm{Hg}$, with the associated uncertainties and risks) will be required for existing and new thermal treatment facilities.

- Additional performance information should be obtained to validate model assumptions concerning (a) Hg removal efficiency in carbon beds, (b) PM and $\mathrm{Hg}$ removal in the wet scrubber, (c) possible $\mathrm{D} / \mathrm{F}$ formation in the SCR reactor, and (d) cumulative impacts of multiple APC equipment connected in series. 


\section{HIGH PERFORMANCE APCS CONCEPTUAL DESIGN AND EVALUATION SCOPING STUDY}

\section{INTRODUCTION}

Thermally treating organic and inorganic mixed waste materials can produce pollutants including particulates, radionuclides, toxic metals, dioxins and furans, and acid gases that must be controlled within prevailing regulatory and permit limits. New proposed limits for some pollutants are significantly more stringent than earlier acceptable emission limits. As a result, current air pollution control system (APCS) configurations may be inadequate in meeting the stricter proposed emission limits without severely restricting the content of potential pollutants or their precursors in the waste feed. The development and deployment of high-performance offgas systems designed with capabilities to meet stricter emission limits under expected and non-normal operating conditions would significantly address the most important stakeholder concerns and may also allow less rigorous feed characterization and control resulting in lower overall treatment costs.

This study was conducted to (a) identify various high-performance APCS configurations designed to meet stricter air emission limits from a mixed waste thermal treatment system, and (b) demonstrate a modeling tool for evaluating the effectiveness of an APCS in meeting those limits.

\subsection{Background}

Thermal treatment of organic and inorganic mixed waste materials can ultimately produce oxidation products such as carbon dioxide and water; entrained or volatilized particulate matter (PM), radionuclides, toxic metals; acid gases; dioxins and furans (D/F); and organic products of incomplete combustion (PICs). Pollutants, including PM, radionuclides, toxic metals, acid gases, and PICs, must be controlled within prevailing regulatory and permit limits. Pollutant emissions are one of the most important stakeholder issues for mixed waste treatment systems. Stakeholder concern is for emissions control not only during routine operation when all of the equipment is operating within design parameters, but also during non-normal conditions including process startup, shutdown, and atypical feed conditions. The U.S. Environmental Protection Agency (EPA) has proposed air pollutant emission standards for hazardous waste incinerators under the Hazardous Waste Combustor Maximum Achievable Control Technology (HWC MACT) Rule (EPA 1996, EPA 1997a). Pollutants expected to be regulated under this rule include mercury, total chlorine (hydrogen chloride and chlorine), semi-volatile metals (SVM) including lead and cadmium, low-volatility metals (LVM) including arsenic, beryllium, and chromium, $\mathrm{PM}, \mathrm{D} / \mathrm{F}$, hydrocarbons (HC), and carbon monoxide. The proposed limits for some pollutants, such as for mercury and total chlorine, are significantly more stringent than earlier acceptable emission limits. As a result, a current APCS configuration that meets existing emission limits may be inadequate to meet restrictions imposed by the proposed MACT Rule.

The Waste Experimental Reduction Facility (WERF) controlled-air incinerator located at the Idaho National Engineering and Environmental Laboratory (INEEL) is an example of a currently acceptable dry APCS. The WERF incinerator processes beta/gamma-emitting low-level radioactive waste. The incinerator APCS consists of a dry particulate filtering system employing offgas dilution with ambient air for cooling the offgas, an air-cooled shell-and-tube heat exchanger for additional heat removal, and a baghouse and high-efficiency particulate air (HEPA) filters to remove particulate matter (Branter 1994). 
The APCS is especially designed for efficient PM control, but it is not capable of effective acid gas or $\mathrm{Hg}$ control. To date, the $\mathrm{Hg}$ and $\mathrm{Cl}$ emissions have been controlled by limiting the $\mathrm{Hg}$ and $\mathrm{Cl}$ content of the waste feed.

The Consolidated Incineration Facility (CIF) utilizes a rotary kiln incinerator followed by a wet APCS. The APCS consists of a water spray quench, a free-jet scrubber, a cyclone separator and mist eliminator for liquid-gas separation, and a reheater prior to the downstream dry HEPA filters (Burns, 1997). The APCS is especially designed for efficient particulate and acid gas removal. Control of $\mathrm{Hg}$ by this APCS has not been adequately demonstrated and may be insufficient to meet expected emission limits without limiting the mercury content in the waste feed.

Development and deployment of high-performance and more reliable offgas systems will significantly help the U.S. Department of Energy (DOE) address stakeholder and regulatory concerns for control of air pollutant emissions especially in light of more stringent proposed regulations. Highperformance offgas systems can be designed with conservatively designed capabilities to meet stricter emission limits under expected and non-normal operating conditions. These offgas systems may allow less rigorous feed characterization and control by eliminating or loosening current restrictions on specific pollutants or their precursors in the waste feed. Rigorous feed characterization and control for most mixed wastes could be very expensive and difficult because of the physical and chemical heterogeneity of the wastes. The Integrated Thermal Treatment System (ITTS) (Feizollahi 1996) and the Integrated Nonthermal Treatment System (INTS) (Biagi 1997) studies estimated the life-cycle cost of the APCS for a mixed waste treatment system was $5 \%$ or less of the total estimated life-cycle cost. Estimated costs for upfront waste handling and characterization ranged up to $30 \%$ of the total costs. The ITTS and INTS studies included offgas system modeling, sizing, and cost estimating as a means of evaluating several different treatment system alternatives. However, the offgas system models and related assumptions used to calculate component partitioning were relatively simple. The detail of the models used in these studies was insufficient for quantitative emissions performance evaluations and mass/energy balances.

\subsection{Technical Approach}

This study used a detailed approach for determining component partitioning, which includes a description of the expected particle size distribution entering the APCS, additional particulate formed during offgas cooling, and partitioning based on chemical thermodynamic equilibria calculations. Additional performance information, such as filter efficiencies and particulate removal efficiencies in the wet scrubber as a function of operating conditions, were used. The study did not consider specifically the fate of radionuclides, although partitioning results for the volatile and nonvolatile toxic metals that were modeled can provide insight to the partitioning trends of volatile and nonvolatile radionuclide constituents. In addition, D/Fs and PICs are not specifically considered in this offgas system model. PICs were considered to be adequately controlled in the upstream primary treatment unit and SCC, which were not included in the scope of this study. The conceptual design evaluated in this study was assumed to adequately control $\mathrm{D} / \mathrm{Fs}$ because it complied with the $\mathrm{D} / \mathrm{F}$ control specifications in the proposed MACT Rule.

The technical approach included the following tasks:

Identify design objectives for high-performance APCS (Section 2). This task identified important design objectives in designing and evaluating high-performance APCS. 
Identify baseline offgas flowrates and compositions from different thermal treatment systems for use in evaluation of high-performance APCS (Section 3). The offgas from mixed waste thermal treatment processes will vary in composition and flowrate, depending on (a) the input waste stream chemical and physical properties, flowrate, variability, and heterogeneity, and (b) treatment process design and operating conditions. Mass balance calculations have been done to establish offgas conditions at the outlet of a hypothetical secondary combustion chamber. These offgas conditions were used in this study.

Identify and conceptually design several alternative high-performance offgas systems (Section 4). These systems must meet or exceed the requirements and treat the offgas determined in Section 3 by using redundant, oversized, or backup conventional control technologies, or various combinations of traditional and innovative designs.

Evaluate selected APCS using ASPEN PLUS process simulator (Sections 5 and 6). ASPEN PLUS is a process simulation code used to calculate species partitioning within an APCS based on thermodynamic equilibrium calculations and particle size data. The process simulator was used to calculate mass and energy balances within an APCS and to demonstrate the effect of operating and process conditions in achieving pollutant emission limits.

Estimate costs of the selected base APCS and incremental costs of additional offgas equipment (Section 7). The total capital costs of the selected base APCS was estimated. In addition, the incremental costs associated with specific pollutant control and temporary offgas retention were estimated. 


\section{OFFGAS SYSTEM DESIGN OBJECTIVES}

Offgas system design objectives for APCS associated with existing or proposed mixed waste thermal treatment systems have been reviewed as a part of this study (Soelberg 1996b, EER 1997, Soelberg 1997b). The most important and fundamental design objectives are listed in Table 2-1.

Current and proposed emissions regulations were considered for particulate, radionuclides, toxic metals, acid gases, and organic pollutants. Applicable emission limits that are relevant to offgas system design and operation downstream of the typical secondary combustion chamber (SCC) are shown in Table 2-2. This table lists current emission limits based on current regulations and expected permit conditions, and also emission limits as defined in the proposed Revised Standards for Hazardous Waste Combustors, also called the Maximum Achievable Control Technology (MACT) Rule (EPA 1996 and EPA 1997a). The MACT Rule is presently proposed and not yet promulgated, is subject to some modifications prior to promulgation, and may not apply to mixed waste treatment in its presently proposed form. To be conservative, however, compliance with the stricter of the current or proposed regulations was generally assumed. In some cases such as for $\mathrm{HCl}$ emissions, the simpler limit from the MACT Rule was assumed even if it may result in a slightly higher emission limit. Regulations that specify proper use and maintenance of offgas equipment were excluded from Table 2-2 and are summarized elsewhere (Soelberg 1997b).

Since the offgas system defined in this study is the equipment downstream of a SCC, regulations that apply to mixed waste treatment process equipment including and upstream of the SCC are not within the scope of this study. The assumption is made that the treatment equipment and the secondary combustion chamber will work as designed and the offgas emissions for such pollutants as total hydrocarbons (THC) will meet applicable regulations.

Both state and federal standards will apply to mixed waste treatment facilities. Current limits that are based on risk assessments also depend on facility location. For the purposes of this study, only federal standards were used because all potential facilities must comply with these standards. State regulations generally will be consistent with federal standards. State regulations that may impose additional or more stringent limits are listed in EER 1997, but are not considered in this study. Federal standards that govern mixed waste treatment are found in various sections of the Code of Federal Regulations (CFR):

- National Emission Standards for Hazardous Air Pollutants (40 CFR 61). While most of these standards are source-specific, three can apply for mixed waste treatment facilities based on waste materials treated in the process. There are some mixed waste streams that contain beryllium, so 40 CFR 61.32 is assumed to apply for beryllium emissions. There are some large mixed waste streams containing sludges produced from wastewater treatment, so 40 CFR 61.52 is assumed to apply for mercury emissions. Since radionuclides are present in mixed waste, 40 CFR 61.92 is assumed to apply.

- Standards for hazardous waste incineration [40 CFR 264, Subpart O (264.340-351)]. These have direct application because mixed waste includes hazardous waste as defined in 40 CFR 261 Appendix VIII, and is regulated under Resource Conservation and Recovery Act (RCRA). The applicability of the incineration rules is assumed for the purpose of system performance even if the primary treatment device is not classed as an "incinerator", because of EPA's Omnibus authority defined in Section 30005(c) of RCRA. 
Table 2-1. Design objectives for mixed waste treatment offgas control systems.

\begin{tabular}{ll}
\hline Design objective & Comments \\
\hline $\begin{array}{l}\text { Control emissions of gaseous } \\
\text { organics, radionuclides, toxic metals, } \\
\text { particulate, and acid gases to meet } \\
\text { expected regulatory limits. }\end{array}$ & $\begin{array}{l}\text { Questions that must be defined include (a) which current or } \\
\text { proposed emission limit values should be used, and (b) how far } \\
\text { below selected limits should the offgas system control } \\
\text { emissions? Targets of one-tenth of the expected limits have } \\
\text { been assumed in Feizollahi 1996, for example. }\end{array}$ \\
$\begin{array}{l}\text { Employ methods to ensure that a } \\
\text { nuclear criticality condition will be } \\
\text { avoided. }\end{array}$ & $\begin{array}{l}\text { Design and operation must avoid any holdup of TRU- } \\
\text { containing solid materials in amounts and concentrations that } \\
\text { could approach criticality, especially in wet systems where the } \\
\text { presence of water can increase the criticality potential. }\end{array}$
\end{tabular}

Accept any likely offgas flowrate and composition variations from the primary treatment process without upsets or degradation of performance beyond acceptable limits.

Operate reliably with minimal downtime and upsets.

This is important for enabling the treatment system to process widely varying feed materials with less rigorous characterization, sorting, significant turndown, or feed additives.

The annual availability of a mixed waste treatment system for actual operation has been estimated at only $50 \%$ or less (4,400 hours or less) in several studies (Eddy 1996, Feizollahi 1996, and Soelberg 1994). Operating costs are the largest single component of a mixed waste treatment facility life cycle costs. Operating costs per unit of waste treated and time required to treat waste increase substantially when availability is decreased.

Comply with ALARA objectives by minimizing the exposure of workers, the public, and the environment to radiological hazards.

An ideal goal would be to operate remotely during normal, routine conditions, although some direct operator-performed maintenance should be expected during shutdowns or unusual conditions. This approach has been made in the preliminary designs reported in Eddy 1995, but existing systems such as the WERF incinerator, and the Savannah River Site CIF, and systems under construction such as the Pit-9 melter system do not have this approach and require hands-on operation while processing waste.

Minimize amounts of secondary streams and maximize ease of secondary stream final treatment and disposal.

Handling and disposal of offgas system secondary product streams can involve significant ALARA and waste form issues because of the potential for concentrated toxic metals and radioactive contamination in or on small particles, regardless of the treatment or offgas system design. 
Table 2-1. Design objectives for mixed waste treatment offgas control systems (continued).

\begin{tabular}{|c|c|}
\hline Design objective & Comments \\
\hline $\begin{array}{l}\text { Minimize total treatment facility life- } \\
\text { cycle cost. }\end{array}$ & $\begin{array}{l}\text { While some higher performance offgas systems that include } \\
\text { more comprehensive monitoring may be more costly to } \\
\text { purchase or operate, they may enable lower overall facility life } \\
\text { cycle costs if less downtime is required or if less upfront feed } \\
\text { characterization, sorting, or blending is required. }\end{array}$ \\
\hline $\begin{array}{l}\text { Comply with all other Applicable or } \\
\text { Relevant and Appropriate } \\
\text { Requirements (ARARs). }\end{array}$ & $\begin{array}{l}\text { For CERCLA remediation facilities, there are a large number of } \\
\text { ARARs that should be addressed. Potential sources of these } \\
\text { ARARs depend on regulator, stakeholder, and operator } \\
\text { discretion and precedence. }\end{array}$ \\
\hline $\begin{array}{l}\text { Minimize technology } \\
\text { implementation risk. }\end{array}$ & $\begin{array}{l}\text { This is important for any components or technologies that are } \\
\text { not well demonstrated, proven, or accepted for the application } \\
\text { in which they are specified. }\end{array}$ \\
\hline $\begin{array}{l}\text { Simplify equipment operation and } \\
\text { maintenance by design. }\end{array}$ & $\begin{array}{l}\text { Achieve reliable operation with minimal downtime and minimal } \\
\text { total facility life cycle cost. }\end{array}$ \\
\hline $\begin{array}{l}\text { Interface adequately with the } \\
\text { treatment process and secondary } \\
\text { waste form handling process. }\end{array}$ & $\begin{array}{l}\text { This is an important systems engineering design objective to } \\
\text { ensure that the entire treatment facility operates as desired. }\end{array}$ \\
\hline
\end{tabular}

- Standards for Boilers and Industrial Furnaces [BIF rules, 40 CFR 266 Subpart H (266.100-112)]. Under EPA's Omnibus authority, emission limits defined in the BIF rules can also apply even though a facility is neither a boiler or an industrial furnace.

- Standards from the Toxic Substance Control Act (TSCA, 40 CFR 761). Section 761 regulates the incineration of wastes that contain PCBs in concentrations greater than or equal to $50 \mathrm{ppmw}$. Some mixed waste streams are known or assumed to contain PCBs in concentrations greater than or equal to $50 \mathrm{ppmw}$.

In addition to EPA standards in the CFR, DOE Order 5280.2A regulates air emissions of radionuclides and hazardous materials by specifying compliance to National Emission Standards for Hazardous Air Pollutants (NESHAP) and RCRA standards, referring back to 40 CFR 61 and 264.343. 
Table 2-2. Current and proposed emission limits.

\begin{tabular}{|c|c|c|c|c|}
\hline \multirow[b]{2}{*}{ Pollutant } & \multicolumn{2}{|c|}{ Current Standard } & \multirow{2}{*}{$\begin{array}{l}\text { Proposed MACT standard (EPA } \\
\text { 1997a) (k) }\end{array}$} & \multirow{2}{*}{$\begin{array}{l}\text { Emission limit assumed } \\
\text { for this study }(k)\end{array}$} \\
\hline & Limit $(k)$ & Reference & & \\
\hline Beryllium & $10 \mathrm{~g} / 24-\mathrm{hrs}$ & 40 CFR 61.32 & - & $-(j)$ \\
\hline Mercury & 3,200 g/24-hrs & 40 CFR 61.52 & $40 \mu \mathrm{g} / \mathrm{dscm}$ & $40 \mu \mathrm{g} / \mathrm{dscm}$ \\
\hline Radionuclides & $10 \mathrm{mrem} / \mathrm{yr}(\mathrm{a})$ & 40 CFR 61.92 & - & $0.1 \mathrm{mrem} / \mathrm{yr}(\mathrm{b})$ \\
\hline POHCs & $99.99 \%$ DRE & 40 CFR 264.343 & - & --(j) \\
\hline $\mathrm{HCl}$ & $\begin{array}{l}1.8 \mathrm{~kg} / \mathrm{hr} \text { or } \mathrm{l} \% \text { of the } \\
\text { uncontrolled } \mathrm{HCl} \text { level }\end{array}$ & 40 CFR 264.343 & - & - \\
\hline Total $\mathrm{HCl}$ and $\mathrm{Cl}_{2}$ & (h) & 40 CFR 266.107 & $75 \mathrm{ppm}(\mathrm{c})$ & $75 \mathrm{ppm}$ \\
\hline PM & $180 \mathrm{mg} / \mathrm{dscm}$ & 40 CFR 264.343 & $35 \mathrm{mg} / \mathrm{dscm}(\mathrm{d})$ & $35 \mathrm{mg} / \mathrm{dscm}$ \\
\hline $\mathrm{CO}$ & $100 \mathrm{ppm}(\mathrm{e})$ & 40 CFR 266.104 & $100 \mathrm{ppm}$ & 100 ppm \\
\hline THC & $-(f)$ & 40 CFR 266.104 & $10 \mathrm{ppm}$ & $10 \mathrm{ppm}$ \\
\hline $\mathrm{D} / \mathrm{F}$ & (g) & 40 CFR 266.104 & $0.2 \mathrm{ng} \mathrm{TEQ} / \mathrm{dscm}$ & $0.2 \mathrm{ng} \mathrm{TEQ} / \mathrm{dscm}$ \\
\hline PCBs & $99.9999 \%$ DRE & 40 CFR 761.70 & - & $-(\mathrm{j})$ \\
\hline BIF metals & (h) & 40 CFR 266.106 & - & $-(j)$ \\
\hline SVM $(\mathrm{Pb}, \mathrm{Cd})$ & - & - & $100 \mu \mathrm{g} / \mathrm{dscm}$ & $100 \mu \mathrm{g} / \mathrm{dscm}$ \\
\hline $\operatorname{LVM}(\mathrm{As}, \mathrm{Be}, \mathrm{Cr})$ & - & - & $55 \mu \mathrm{g} / \mathrm{dscm}$ & $55 \mu \mathrm{g} / \mathrm{dscm}$ \\
\hline PICs & (l) & Draft PIC Guide & - & $-(j)$ \\
\hline \multicolumn{5}{|c|}{$\begin{array}{l}\text { a. Effective dose equivalent for any member of the public from total radionuclide emissions. This limit is typically far lower, such as } 0.1 \\
\text { mrem/yr, for specific treatment systems that are located at a larger site, because the entire site limit is } 10 \mathrm{mrem} / \mathrm{yr} \text {. } \\
\text { b. A lower limit of } 0.1 \text { mrem/yr is assumed. } \\
\text { c. Unless otherwise noted, concentrations are on a volumetric, dry basis corrected to } 7 \% \text { excess oxygen (or representative oxygen level for } \\
\text { treatment processes in which oxygen or oxygen-enriched air is used as an oxidant). } \\
\text { d. Unless otherwise noted, concentrations are on a dry basis corrected to } 7 \% \text { excess oxygen (or representative oxygen level for treatment } \\
\text { processes in which oxygen or oxygen-enriched air is used as an oxidant). } \\
\text { e. The CO limit, if the CO level exceeds } 100 \mathrm{ppm,} \mathrm{may} \mathrm{be} \mathrm{established} \mathrm{in} \mathrm{a} \mathrm{trial} \mathrm{bum,} \mathrm{providing} \mathrm{that} \mathrm{the} \mathrm{THC} \mathrm{level} \mathrm{does} \mathrm{not} \mathrm{exceed} 20 \mathrm{ppm} \text {. } \\
\text { f. Or, if the CO level exceeds } 100 \mathrm{ppm} \text { the THC limit is } 20 \mathrm{ppm} \text {. } \\
\text { g. For facilities that have dry PM control in the } 450-750^{\circ} \text { temperature range, determine by stack emission measurements and risk assessment } \\
\text { that emissions of D/F do not result in increased lifetime cancer risk to a hypothetical maximum exposed individual (MEI) exceeding } 1: 100,000 \\
\text { (base emission limit on the emission rate that would result in 1:100,000 risk of increased lifetime cancer to MEI). } \\
\text { h. Must comply with either Tier } 1 \text { feed limits, Tier II Emission screening limits, or Tier III emission dispersion limits. } \\
\text { I. Conduct a detailed exposure assessment, which includes measurements for the } 12 \text { BIF metals, many organic PICs, } 20 \text { largest peaks on a } \\
\text { GC/MS scan, D/F, full PCB scan, highly toxic compounds in the waste, and nitrogenated organic compounds (EER 1997). } \\
\text { j. Permit writers may in fact specify compliance for these pollutants according to the existing NESHAP, RCRA, BIF, or Draft PIC Guide } \\
\text { requirements. However, because these are (a) site-specific requirements for which a general limit is not available, (b) requirements of the } \\
\text { primary treatment device and SCC, or (c) considered to be adequately covered by surrogates (such as THC) by the proposed MACT Rule, } \\
\text { specific limits will not be used in this study for these pollutants. } \\
\text { k. Many of the limits are based on 1-10 hour rolling averages. }\end{array}$} \\
\hline
\end{tabular}




\section{INPUT OFFGAS FLOWRATES AND COMPOSITIONS}

The design and performance of any APCS depend on the properties of the offgas to be treated, which in turn depend on the properties and processing rate of the input waste as well as the design and operation of the thermal treatment system. An evaluation was conducted to determine reference offgas flowrates and compositions as well as the flowrate, particle size distribution, and composition of particulate matter (PM) being generated from a thermal treatment system. Using reference offgas input conditions for this study enables the comparison of performance, size, and cost on the same basis for different APC systems. The varieties and compositions of DOE mixed wastes were evaluated to estimate the minimum, normal, and maximum PM and offgas flowrates and compositions that would result from thermal treatment.

Two separate thermal treatment cases were considered which reasonably bracket the kinds of thermal treatment technologies presently available or being planned for mixed waste treatment. A relatively high offgas flowrate case (high-flow) resulted from the use of fossil-fired, air combustion thermal treatment represented by an air-fired rotary kiln with an air-fired SCC. A much lower offgas flowrate (low-flow) was produced when electrical heat generation and oxygen combustion was considered in the second case represented by the various plasma arc treatment technologies. The results of this evaluation are summarized in this section and are described in detail in Appendix A.

The mixed waste composition was based on earlier descriptions (Huebner 1994). While the DOE Interim Mixed Waste Inventory Report was also available (DOE 1993) and is often used as a standard for describing volumes of DOE site-wide mixed wastes, this report does not include waste masses or compositions that were needed in this evaluation. Waste feed flowrate and composition, offgas flowrates and compositions, and PM flowrates and compositions were based on those from the ITTS study (Feizollahi 1995) with some exceptions. These exceptions are noted in Appendix A and are based primarily on the use of improved assumptions or additional data that were not available at the time of the ITTS study. A reference waste feedrate of $2,149 \mathrm{lb} / \mathrm{hr}$, which was the feedrate for the ITTS systems A-7 (slagging rotary kiln, air combustion) and $\mathrm{C}-2$ (plasma furnace, $\mathrm{O}_{2}$ combustion, $\mathrm{CO}_{2}$ retention), was selected.

\subsection{Input Offgas}

The input offgas flowrates and compositions used in this study are shown in Table 3-1. These flowrates and compositions were based on the ASPEN PLUS simulation of the ITTS A-7 and C-2 systems with some relatively minor adjustments based on comparisons to actual offgas flowrates produced from treatment system demonstrations and actual operations under some similar process conditions. Only fully oxidized offgas, as typical for the outlet of a secondary combustion chamber, was considered as input gas.

The maximum SCC outlet offgas flowrates for the high-flow and low-flow cases from Appendix A were selected for input flowrates so that the offgas equipment was sized to accept the maximum flowrates. The average offgas compositions were generally used, however, for the offgas compositions, because the maximum composition levels for $\mathrm{O}_{2}, \mathrm{~N}_{2}, \mathrm{CO}_{2}$, and $\mathrm{H}_{2} \mathrm{O}$ would not all occur at the same time-otherwise, the offgas composition values would sum to greater than $100 \%$. Maximum concentration values for ppmlevel species $\left(\mathrm{CO}, \mathrm{NO}_{x}, \mathrm{HCl}\right.$ and $\left.\mathrm{Cl}_{2}\right)$ were selected to be conservatively high for these pollutants. The concentrations of $\mathrm{O}_{2}, \mathrm{~N}_{2}$, and $\mathrm{H}_{2} \mathrm{O}$ were adjusted slightly so that the sum of the offgas constituents (not including volatilized $\mathrm{PM}$ ) totaled $100 \%$. 
Table 3-1. Input offgas conditions at the outlet of the secondary combustion chamber.

\begin{tabular}{|c|c|c|c|}
\hline Parameter & High-flow case & Low-flow case & Comments \\
\hline Offgas temperature, ${ }^{\circ} \mathrm{F}$ & 2,200 & 2,200 & $\begin{array}{l}\text { Design temperature for the } \\
\text { SCC outlet }\end{array}$ \\
\hline Offgas flowrate, scfm & 6,715 & 3,429 & (a) \\
\hline \multicolumn{4}{|c|}{ Offgas composition, (by volume): } \\
\hline Oxygen, \% & 7 & 14 & (b) \\
\hline Nitrogen, $\%$ & 74 & 5 & (b) \\
\hline $\mathrm{CO}_{2}, \%$ & 8 & 30 & (b) \\
\hline $\mathrm{H}_{2} \mathrm{O}, \%$ & 10 & 48 & (b) \\
\hline $\mathrm{CO}, \mathrm{ppm}$ & 10 & 10 & (a) \\
\hline $\mathrm{NO}_{x}, \mathrm{ppm}$ & 4,000 & 4,000 & (a), (c) \\
\hline $\mathrm{HCl}, \mathrm{ppm}$ & 2,500 & 25,000 & (a) \\
\hline $\mathrm{Cl}_{2}, \mathrm{ppm}$ & 5 & 100 & (a) \\
\hline $\mathrm{SO}_{2}, \mathrm{ppm}$ & 100 & 1,000 & (a) \\
\hline Total & 100 & 100 & $\begin{array}{l}\text { Concentrations of oxygen, } \\
\text { nitrogen, and } \mathrm{H}_{2} \mathrm{O} \text { are } \\
\text { adjusted to enable sum to } \\
\text { equal } 100 \%\end{array}$ \\
\hline \multicolumn{4}{|c|}{ Note: The number of digits in a value does not indicate the number of significant figures. } \\
\hline \multicolumn{4}{|c|}{$\begin{array}{l}\text { a. Maximum value from Appendix A, Table A-4. } \\
\text { b. Normal value from Appendix A, Table A-4. } \\
\text { c. } \mathrm{NO}_{\mathrm{x}} \text { is assumed to be } 100 \% \text { NO. }\end{array}$} \\
\hline
\end{tabular}




\subsection{Input Volatilized and Condensed Particulate Matter}

The partitioning of 11 metals was specifically modeled because these metals are considered hazardous and are found in the waste based on composition information (Huebner 1994). These metals were $\mathrm{Hg}, \mathrm{Cd}, \mathrm{Pb}, \mathrm{As}, \mathrm{Be}, \mathrm{Cr}, \mathrm{Sb}, \mathrm{Ba}$, Se, $\mathrm{Ag}$, and $\mathrm{Ta}$. Total particulate matter ( $\mathrm{PM}$ ) was defined to include offgas solids (flyash), entrained vapor condensate, and volatilized metals. The bulk of the total particulate matter includes other common metal species which were assumed to be nonvolatile and chemically inert. The input concentrations of the 11 metals evaluated in this study are listed in Table 3-2.

Because filter efficiencies were usually defined in terms of particles approximately $0.5 \mu \mathrm{m}$ in size, a particle size distribution was estimated for both thermal treatment systems in terms of particles greater and less than $0.5 \mu \mathrm{m}$. Two reports suggest that approximately $60 \%$ of particles exiting an air-combustion process are greater than $0.5 \mu \mathrm{m}$ (EPA 1992 and Dalton 1992), so this value was used for the high-flow case (Table 3-2). Approximately $60 \%$ of particles exiting a low-flow thermal treatment process were less than $0.5 \mu \mathrm{m}$ (Dalton 1992).

The total PM input composition and flowrate (Table 3-3) were determined based on the waste input feedrate to the primary treatment system, ranges for assumed and measured values for total PM carryover, and partitioning of the 11 key metals determined from chemical equilibrium modeling. The computer software HSC Chemistry for Windows was used to calculate chemical equilibria of each metal at $2,200^{\circ} \mathrm{F}$ (the design operating temperature for the SCC) with excess oxygen, water, and hydrogen chloride. HSC Chemistry utilizes an extensive thermodynamic database that contains data for over 7,600 chemical compounds. Chemical equilibrium calculations showed that three metals $(\mathrm{Be}, \mathrm{Ta}$, and $\mathrm{Cr}$ ) would exist as solid oxides under the high-temperature conditions. Thus, it was assumed that only a small fraction of these metals ( $10 \%$ of $\mathrm{Ta}, \mathrm{Cr} ; 1 \%$ of $\mathrm{Be}$ ) that may be present in the thermal treatment system become entrained as particulate carryover. The other eight metals could exist significantly in the vapor phase as either the element (in the case of $\mathrm{Hg}$ ), the chloride ( $\mathrm{Ag}, \mathrm{Ba}, \mathrm{Cd}$, and $\mathrm{Pb}$ ), or the oxide ( $\mathrm{As}, \mathrm{Sb}$, and $\mathrm{Se}$ ). Total carryover of $100 \%$ from the thermal treatment unit was conservatively assumed for these eight metals. The composition of the rest of the particulate matter was defined using the relative composition of the major components listed in Table A-3 in Appendix A.

Total particulate carryover used in the ITTS study was $20 \%$ of the input feed for the system A-7. After comparison with lower measured and estimated values for total carryover from several other studies, the total PM flowrate in the reference offgas for this study was $329 \mathrm{lb} / \mathrm{hr}$, or approximately $15 \%$ of the treatment system waste input feedrate of $2,149 \mathrm{lb} / \mathrm{hr}$. This total PM carryover value is conservatively high because most measurements from mixed waste demonstration tests have shown lower total carryover values of $1-10 \%$ of the waste input feedrate (Soelberg 1997a).

Radionuclides were not specifically modeled at this time. Key radionuclides such as $\mathrm{Am}-241, \mathrm{Pu}-$ 238 through Pu-241, U-232 through U-238, Ba-137, Co-60, Sr-90, Cs-137, Y-90, Zn-65, C-14, H-3, and I129 may be added at a later time. 
Table 3-2. Input volatilized and entrained metals at the outlet of the secondary combustion chamber.

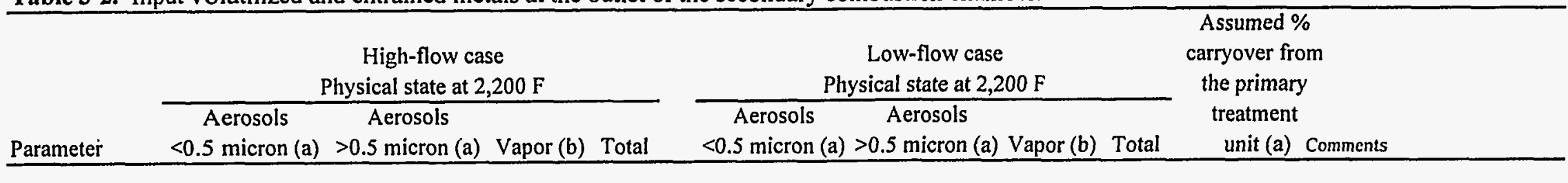

Particle size

40

60

60

40

From EPA 1992 and Dalton 1992

distribution, wt $\%$

Flowrates of elemental metals from Appendix A, Table 5, lb/hr:

(Relatively low volatile)

\begin{tabular}{|c|c|c|c|c|c|c|c|c|c|c|}
\hline $\mathrm{Be}$ & 3.10 & 4.64 & -- & 7.74 (c) & 4.64 & 3.10 & -- & 7.74 (c) & 1 & Carryover of low volatile \\
\hline $\mathrm{Cr}$ & 1.72 & 2.58 & -- & 4.30 (d) & 2.58 & 1.72 & --- & 4.30 (d) & 10 & metals due wholly to particle \\
\hline $\mathrm{Ta}$ & 0.09 & 0.13 & --- & 0.22 (d) & 0.01 & 0.01 & -- & 0.02 & 10 & entrainment, not volatilization \\
\hline
\end{tabular}

(Relatively volatile)

\begin{tabular}{|c|c|c|c|c|c|c|c|c|c|c|c|}
\hline $\mathrm{Ag}$ & --- & -- & 1.08 & 1.08 (d) & -..- & --- & 1.08 & 1.08 & (d) & 100 & Carryover of relatively \\
\hline As & $\cdots$ & --- & 4.30 & 4.30 (d) & --- & -- & 4.30 & 4.30 & (d) & 100 & volatile metals due wholly to \\
\hline $\mathrm{Ba}$ & $\cdots$ & -- & 5.37 & 5.37 (d) & -- & $\cdots$ & 5.37 & 5.37 & (d) & 100 & volatilization, not particle \\
\hline $\mathrm{Cd}$ & $\cdots$ & --- & 32.25 & 32.25 (d) & $\cdots$ & -- & 32.25 & 32.25 & (d) & 100 & entrainment. \\
\hline $\mathrm{Hg}$ & $\cdots$ & -- & 10.74 & 10.74 (d) & ... & -- & 10.74 & 10.74 & (d) & 100 & \\
\hline $\mathrm{Pb}$ & -- & -- & 21.49 & 21.49 (d) & -- & -- & 21.49 & 21.49 & (d) & 100 & \\
\hline $\mathrm{Sb}$ & $\cdots$ & $-\cdots$ & 3.22 & 3.22 (d) & -- & $-\cdots$ & 3.22 & 3.22 & (d) & 100 & \\
\hline $\mathrm{Se}$ & $\ldots$ & -- & 2.15 & 2.15 (d) & $\cdots$ & -- & 2.15 & 2.15 & (d) & 100 & \\
\hline
\end{tabular}

Note: the number of digits in a value does not indicate the number of significant figures.

a. Aerosol-form metals and PM are listed in this column based on the estimated particle size distribution.

b. These elements were found to be in vapor phase based on chemical equilibrium modeling conducted using $\mathrm{HSC}$ Chemistry at $2,200 \mathrm{~F}$, with excess $\mathrm{O} 2, \mathrm{H} 2 \mathrm{O}$, and $\mathrm{HCl}$.

c Calculated using $1 \%$ carryover for maximum Be value from Appendix A, Table 5. Only 1\% carryover was assumed on the basis that Be metal, while a major component of some waste streams, is not present in most waste streams. When it is present, it is present as the relatively high boiling point metal $(2,500 \mathrm{C}$ boiling point).

d. Maximum values from Appendix A, Table A-5. 
Table 3-3. Flowrates and concentrations of the particulate matter at the outlet of the secondary combustion chamber.

\begin{tabular}{|c|c|c|c|c|c|c|c|c|}
\hline \multirow[b]{2}{*}{ Parameter } & \multicolumn{4}{|c|}{ High-flow case $(2,200 \mathrm{~F})$} & \multicolumn{4}{|c|}{ Low-flow case $(2,200 \mathrm{~F})$} \\
\hline & $\begin{array}{c}\text { Aerosols } \\
<0.5 \text { micron (a) }\end{array}$ & $\begin{array}{c}\text { Aerosols } \\
>0.5 \text { micron (b) }\end{array}$ & Vapor (c) & Total & $\begin{array}{c}\text { Aerosols } \\
<0.5 \text { micron (b) }\end{array}$ & $\begin{array}{c}\text { Aerosols } \\
>0.5 \text { micron (a) }\end{array}$ & Vapor (c) & Total \\
\hline \multicolumn{9}{|c|}{ Flowrate of $\mathrm{PM}, \mathrm{lb} / \mathrm{hr}$ (mass flowrates of species of above elements are renormalized based on molecular/atomic weights): } \\
\hline $\mathrm{AgCl}$ & & & 1.43 & 1.43 & & & 1.43 & 1.43 \\
\hline $\mathrm{AsO}$ & & & 5.22 & 5.22 & & & 5.22 & 5.22 \\
\hline $\mathrm{BaCl}_{2}$ & & & 8.14 & 8.14 & & & 8.14 & 8.14 \\
\hline $\mathrm{BeO}$ & 8.59 & 12.89 & & 21.48 & 12.89 & 8.59 & & 21.48 \\
\hline $\mathrm{CdCl}_{2}$ & & & 52.59 & 52.59 & & & 52.59 & 52.59 \\
\hline $\mathrm{CrO}_{2}$ & 2.78 & 4.17 & & 6.95 & 4.17 & 2.78 & & 6.95 \\
\hline $\mathrm{Hg}$ & & & 10.74 & 10.74 & & & 10.74 & 10.74 \\
\hline $\mathrm{PbCl} 2$ & & & 28.84 & 28.84 & & & 28.84 & 28.84 \\
\hline $\mathrm{SbO}$ & & & 3.64 & 3.64 & & & 3.64 & 3.64 \\
\hline $\mathrm{SeO}_{2}$ & & & 3.02 & 3.02 & & & 3.02 & 3.02 \\
\hline $\mathrm{Ta}_{2} \mathrm{O}_{5}$ & 0.21 & 0.32 & & 0.54 & 0.32 & 0.21 & & 0.54 \\
\hline All Other & 74.41 & 111.62 & & 186.04 & 111.62 & 74.41 & & 186.04 \\
\hline Total PM & 86.00 & 129.00 & 113.64 & 328.64 & 129.00 & 86.00 & 113.64 & 328.64 \\
\hline \multicolumn{9}{|c|}{ Concentration of PM, mg/dscm: } \\
\hline $\mathrm{AgCl}$ & & & 63.38 & 63.38 & & & 214.83 & 214.83 \\
\hline $\mathrm{AsO}$ & & & 230.50 & 230.50 & & & 781.24 & 781.24 \\
\hline $\mathrm{BaCl}_{2}$ & & & 359.66 & 359.66 & & & $1,219.02$ & $1,219.02$ \\
\hline $\mathrm{BeO}$ & 379.53 & 569.30 & & 948.84 & $1,929.57$ & $1,286.38$ & & $3,215.95$ \\
\hline $\mathrm{CdCl}_{2}$ & & & $2,323.17$ & $2,323.17$ & & & $7,874.04$ & $7,874.04$ \\
\hline $\mathrm{CrO}_{2}$ & 122.73 & 184.10 & & 306.83 & 623.96 & 415.98 & & $1,039.94$ \\
\hline $\mathrm{Hg}$ & & & 474.40 & 474.40 & & & $1,607.91$ & $1,607.91$ \\
\hline $\mathrm{PbCl} 2$ & & & $1,274.05$ & $1,274.05$ & & & $4,318.23$ & $4,318.23$ \\
\hline $\mathrm{SbO}$ & & & 160.92 & 160.92 & & & 545.42 & 545.42 \\
\hline $\mathrm{SeO}_{2}$ & & & 133.45 & 133.45 & & & 452.33 & 452.33 \\
\hline $\mathrm{Ta}_{2} \mathrm{O}_{5}$ & 9.49 & 14.24 & & 23.73 & 48.26 & 32.17 & & 80.43 \\
\hline All Other & $3,286.97$ & $4,930.46$ & & $8,217.43$ & $16,711.10$ & $11,140.73$ & & $27,851.84$ \\
\hline Total PM & $3,798.73$ & $5,698.10$ & $5,019.54$ & $14,516.36$ & $19,312.90$ & $12,875.26$ & $17,013.02$ & $49,201.18$ \\
\hline $\begin{array}{l}\text { Note: the } t \\
\text { a. These s } \\
\text { b. These s } \\
\text { c. Based o }\end{array}$ & $\begin{array}{l}\text { of digits in a val } \\
\text { exist as solids at } \\
\text { exist as solids at } \\
\text { ical equilibrium }\end{array}$ & $\begin{array}{l}\text { e does not indicat } \\
, 200 \mathrm{~F} \text { and are } \mathrm{di} \\
2,200 \mathrm{~F} \text { and are } \mathrm{d} \\
\text { todeling conducte }\end{array}$ & $\begin{array}{l}\text { the number } \\
\text { tributed acc } \\
\text { tributed acc } \\
\text { using HSC }\end{array}$ & $\begin{array}{l}\text { significant } \\
\text { ting to the a } \\
\text { ding to the } \\
\text { temistry at }\end{array}$ & $\begin{array}{l}\text { res. } \\
\text { nption that } 40 \% \text { w } \\
\text { nption that } 60 \% \text { w } \\
F \text {, with excess ox }\end{array}$ & $\begin{array}{l}\text { ill be less than } 0 . \\
\text { ill be greater than } \\
\text { ygen, water, and I }\end{array}$ & $\begin{array}{l}\text { micron in s } \\
.5 \text { micron } \\
\text { Cl. }\end{array}$ & ize. \\
\hline
\end{tabular}




\section{HIGH-PERFORMANCE APCS DESIGNS}

Several APC systems have been conceptualized, designed, or implemented for DOE-sponsored mixed waste treatment technology evaluations or demonstrations (Brown 1995, Dalton 1994, Eddy 1995, Feizollahi 1995, MSE 1994, O’Connor 1995). There are also many variations of offgas control systems installed and used worldwide in radioactive waste treatment processes (IAEA 1989). Various conceptual designs for offgas systems are described in Table 4-1. The first six are summaries of the main offgas systems that are included in the ITTS Phase 1 and Phase 2 studies, which are all dry-wet systems (partial cooling, dry particulate filtration, and then wet acid gas scrubbing). This table also includes a version of a wet-dry system (total quench and wet scrubbing for both particulate and acid gases) conceptualized at INEEL for the Idaho Waste Processing Facility (IWPF). This wet/dry system is similar to other wet/dry systems such as the offgas systems for the Savannah River Site Consolidated Incineration Facility and the INEEL Pit-9 melter offgas system.

High-performance offgas systems were conceptually designed to better tolerate system upsets and continue to meet pollutant emission limits through the use of various combinations of traditional and innovative designs. Potential high-performance offgas system conceptual designs are summarized in Table 4-2. These are designated R-1 through R-7. The flowsheets of these conceptual designs are listed in Appendix B. These systems are generally based on the ITTS and IWPF designs.

\subsection{Dry-wet and Wet-dry APC Systems}

Two main offgas system design categories have evolved to date from DOE-sponsored mixed waste treatment system development and demonstration efforts. These are termed the "dry-wet" and "wet-dry" systems. Either one of these can be well suited for controlling emissions from mixed-waste treatment processes. Both of these categories are represented in Tables 4-1 and 4-2. In the dry-wet system, particulate (including most of the toxic metals and radionuclides) is removed in a dry secondary stream that may be readily recycled to the melter or immobilized for final disposal. Acid gases are removed by wet scrubbing following the particulate removal. The dry-wet system may use lower temperature baghouses or high temperature filters for the initial particulate control, followed by wet acid gas scrubbing. In the wetdry system, all contaminants, including particulate, radionuclides, toxic metals and acid gases, are wet scrubbed and produce a single secondary aqueous mixed waste with some suspended and dissolved particulate material. Both of these systems require cooling, reheating, and HEPA filtration. Because of the differences in particulate and acid gas control, each of the systems has distinct advantages and disadvantages which are summarized in Table 4-3.

\subsection{Baseline High-performance APCS}

The high-performance APCS R-1 was selected for process simulation. This selection was made because it is similar to the ITTS A-1 offgas system, except that is has several "high-performance" features that are representative of the other high-performance systems. While it is a dry-wet rather than wet-dry system, it includes the key components of the wet-dry systems, and also includes an upfront baghouse. A simplified schematic of this system is shown in Figure 4-1. This dry-wet system has many features that satisfy design objectives and make it a likely candidate for deployment in mixed waste treatment: 
Table 4-1. APCS designs from the ITTS study and the IWPF project.

\begin{tabular}{|c|c|c|c|c|c|c|c|c|c|c|c|c|}
\hline \multirow[b]{2}{*}{ System } & \multicolumn{12}{|c|}{ Functional Operations } \\
\hline & $\begin{array}{l}\text { Gas } \\
\text { cooling }\end{array}$ & Particulate control & Gas cooling & Acid gas control & $\begin{array}{l}\text { Gas } \\
\text { reheating }\end{array}$ & $\begin{array}{l}\mathrm{CO}_{2} \\
\text { absorption }\end{array}$ & $\begin{array}{l}\text { Hg \& trace } \\
\text { organics } \\
\text { control }\end{array}$ & HEPA filtration & $\begin{array}{l}\mathrm{NO}_{x} \\
\text { conirol }\end{array}$ & Continuous monitoring & $\begin{array}{l}\mathrm{CO}_{2} \\
\text { remo- } \\
\text { val }\end{array}$ & Omgas retention \\
\hline $\begin{array}{l}\text { ITTS A-1, A-7, } \\
\text { J-1 (dry-1vet, } \\
\text { air oxidation, } \\
\text { frec-jet } \\
\text { scrubber, no } \\
\text { CO/gas } \\
\text { retention }\end{array}$ & $\begin{array}{l}\text { Evapor } \\
\text { ative } \\
\text { vater } \\
\text { cooler, } \\
\text { partial }\end{array}$ & $\begin{array}{l}\text { Dry baghouse, followed } \\
\text { by dual carbon nifters } \\
\text { and HEPA filters for. } \\
\text { Hg, irace organics, and } \\
\text { particulate control }\end{array}$ & $\begin{array}{l}\text { Weter } \\
\text { cvaporative } \\
\text { cooling }\end{array}$ & $\begin{array}{l}\text { Pressure-atomized } \\
\text { free-jet scrubber, } \\
\text { phase separator, } \\
\text { packed tower, mist } \\
\text { eliminator }\end{array}$ & $\begin{array}{l}\text { Electric or } \\
\text { sleam? }\end{array}$ & $\ldots$ & $\begin{array}{l}\text { Following } \\
\text { particulate } \\
\text { control }\end{array}$ & $\begin{array}{l}\text { Following } \\
\text { particulate } \\
\text { control }\end{array}$ & $\begin{array}{l}\text { yes. } \\
\text { probably } \\
\mathrm{NH}_{3} \\
\text { injecled } \\
\text { SCR }\end{array}$ & Not specified & $\ldots$ & -- \\
\hline $\begin{array}{l}\text { ITTS C-2 (dry- } \\
\text { wet, } \mathrm{O}_{2} \\
\text { oxidation, } \mathrm{CO}_{2} \\
\text { abs., gass } \\
\text { retention) }\end{array}$ & $\begin{array}{l}\text { Evapor } \\
\text { ative } \\
\text { water } \\
\text { cooler, } \\
\text { partial }\end{array}$ & $\begin{array}{l}\text { Dry baghouse, followed } \\
\text { by dual carbon nitters } \\
\text { and HEPA filters for } \\
\text { Hg, iraco organics, and } \\
\text { particulate control }\end{array}$ & - & Dry senubber & $\begin{array}{l}\text { Reheat to } \\
650^{\circ} \mathrm{C} \\
\text { (electric?) }\end{array}$ & $\begin{array}{l}\text { Fluidized } \\
\text { bed } \mathrm{CO}_{2} \\
\text { adsorber } \\
\text { with } \\
\text { quifcklime } \\
\text { (CaO) }\end{array}$ & $\begin{array}{l}\text { Following } \\
\text { particulate } \\
\text { control }\end{array}$ & $\begin{array}{l}\text { Following } \\
\text { particulate } \\
\text { control, and also } \\
\text { fina! HEPAs }\end{array}$ & $\ldots$ & Same as ITTS A-1 & ..- & $\begin{array}{l}2 \text { retention tanks } \\
\text { prior to final } \\
\text { HEPAs, and some } \\
\text { of gigas recycle for } \\
\text { torch gas? }\end{array}$ \\
\hline $\begin{array}{l}\text { Irrs c-3 } \\
\text { (reduced } \\
\text { offgas) }\end{array}$ & $\begin{array}{l}\text { Evapor } \\
\text { ative } \\
\text { water } \\
\text { cooler, } \\
\text { partial }\end{array}$ & $\begin{array}{l}\text { Dry baghouse, followed } \\
\text { by dual carbon filters } \\
\text { and HEPA filters for } \\
\text { Hg, trace organics, and } \\
\text { particulate control }\end{array}$ & $\begin{array}{l}\text { Water } \\
\text { evaporative } \\
\text { cooling }\end{array}$ & $\begin{array}{l}\text { Pressurc-atomized } \\
\text { frec-jet scrubber, } \\
\text { phase scparator, } \\
\text { packed tower, mist } \\
\text { eliminator }\end{array}$ & $\begin{array}{l}\text { Electric or } \\
\text { stcam? }\end{array}$ & $\ldots$ & $\begin{array}{l}\text { Following } \\
\text { particulate } \\
\text { control }\end{array}$ & $\begin{array}{l}\text { Following } \\
\text { particulate } \\
\text { control }\end{array}$ & $\begin{array}{l}\text { yes- } \\
\text { probably } \\
\text { NHI3- } \\
\text { injected } \\
\text { SCR }\end{array}$ & Not specified & $\ldots$ & $\ldots$ \\
\hline $\begin{array}{l}\text { ITTS F-1 (Dry- } \\
\text { wel) }\end{array}$ & $\begin{array}{l}\text { Evapor } \\
\text { ative } \\
\text { water } \\
\text { cooler, } \\
\text { partial }\end{array}$ & Dry baghouse & $\begin{array}{l}\text { Full quench } \\
\text { at scrubber } \\
\text { inlet }\end{array}$ & $\begin{array}{l}\text { Wet centriiugal } \\
\text { scrubber }\end{array}$ & $\begin{array}{l}\text { Electric or } \\
\text { steam? }\end{array}$ & $\cdots$ & $\begin{array}{l}\text { Activated } \\
\text { carbon } \\
\text { fillers }\end{array}$ & $\begin{array}{l}\text { Cleanable SS } \\
\text { HEPAs }\end{array}$ & $\cdots$ & Same as ITTS A-1 & $\ldots$ & $\ldots$ \\
\hline $\begin{array}{l}\text { ITTS G-1 } \\
\text { (Dry-wet with } \\
\text { cleaning of } \\
\text { syngas, then } \\
\text { final thermal } \\
\text { oxid. or steam } \\
\text { generation }\end{array}$ & $\begin{array}{l}. . \\
.\end{array}$ & $\begin{array}{l}\text { High temp filter } \\
\text { folliowed by dual carbon } \\
\text { nilters and HEPA filters } \\
\text { for Hg, trace organics, } \\
\text { and particulate control } \\
\text { (no indicated cooling) }\end{array}$ & $\begin{array}{l}\text { Full quench } \\
\text { at scrubber } \\
\text { inlet }\end{array}$ & Wet serubber & $\ldots$ & $\cdots$ & $\begin{array}{l}\text { Following } \\
\text { particulate } \\
\text { control }\end{array}$ & $\begin{array}{l}\text { Following } \\
\text { particulate } \\
\text { control }\end{array}$ & $\ldots$ & Samo as ITTS A-1 & $\ldots$ & $\ldots$ \\
\hline $\begin{array}{l}\text { ITTS H-1 } \\
\text { (Dry-wet with } \\
\text { hot cyclone and } \\
\text { ceramic filter) }\end{array}$ & $\ldots$ & $\begin{array}{l}\text { Hot cyclone and ceramic } \\
\text { filters }\end{array}$ & $\begin{array}{l}\text { Full quench } \\
\text { at scnubber } \\
\text { inlet }\end{array}$ & Venturi scrubber & $\begin{array}{l}\text { Electric or } \\
\text { steam? }\end{array}$ & $\ldots$ & $\begin{array}{l}\text { Activated } \\
\text { carbon } \\
\text { filters }\end{array}$ & $\begin{array}{l}\text { Cleanable SS } \\
\text { HEPAs }\end{array}$ & $\ldots$ & Same as ITTS A-I & -- & $\cdots$ \\
\hline IWPF Wet-dry & $\begin{array}{l}\text { water } \\
\text { spray } \\
\text { total } \\
\text { quench }\end{array}$ & $\begin{array}{l}\text { Free-jet scrubber with } \\
\text { mist eliminator }\end{array}$ & $\ldots$ & $\begin{array}{l}\text { Same free-jet } \\
\text { scrubber }\end{array}$ & $\begin{array}{l}\text { Stesm or } \\
\text { electric }\end{array}$ & - & $\begin{array}{l}\text { Carbon } \\
\text { filters wilh } \\
\text { appr. media } \\
\text { (S, Au, ctc) }\end{array}$ & $\begin{array}{l}\text { Prefilters upstrm } \\
\text { of carbon filters } \\
\text { and HEPAs afler }\end{array}$ & $\ldots$ & $\begin{array}{l}\mathrm{O}_{2,} \mathrm{CO}, \mathrm{THC}, \mathrm{Hg}_{\mathrm{g}}, \mathrm{PM}, \\
\text { beta/gamma, and alpha; } \\
\text { Optional: SVMs, LVMS, HCl, } \\
\text { and Cl }\end{array}$ & - & $\ldots$ \\
\hline $\begin{array}{l}\text { Notes: } \\
\text { a. Thermal oxi } \\
\text { b. Other robust }\end{array}$ & 00 & Sertive (a) & 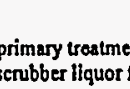 & 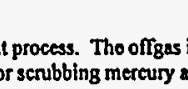 & (2) & ( > & 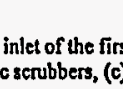 & cooling stag & 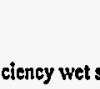 & 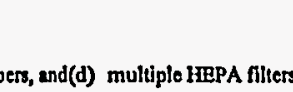 & ( & is in series. \\
\hline
\end{tabular}


Table 4-2. High-performance APCS conceptual designs.

Functional operations

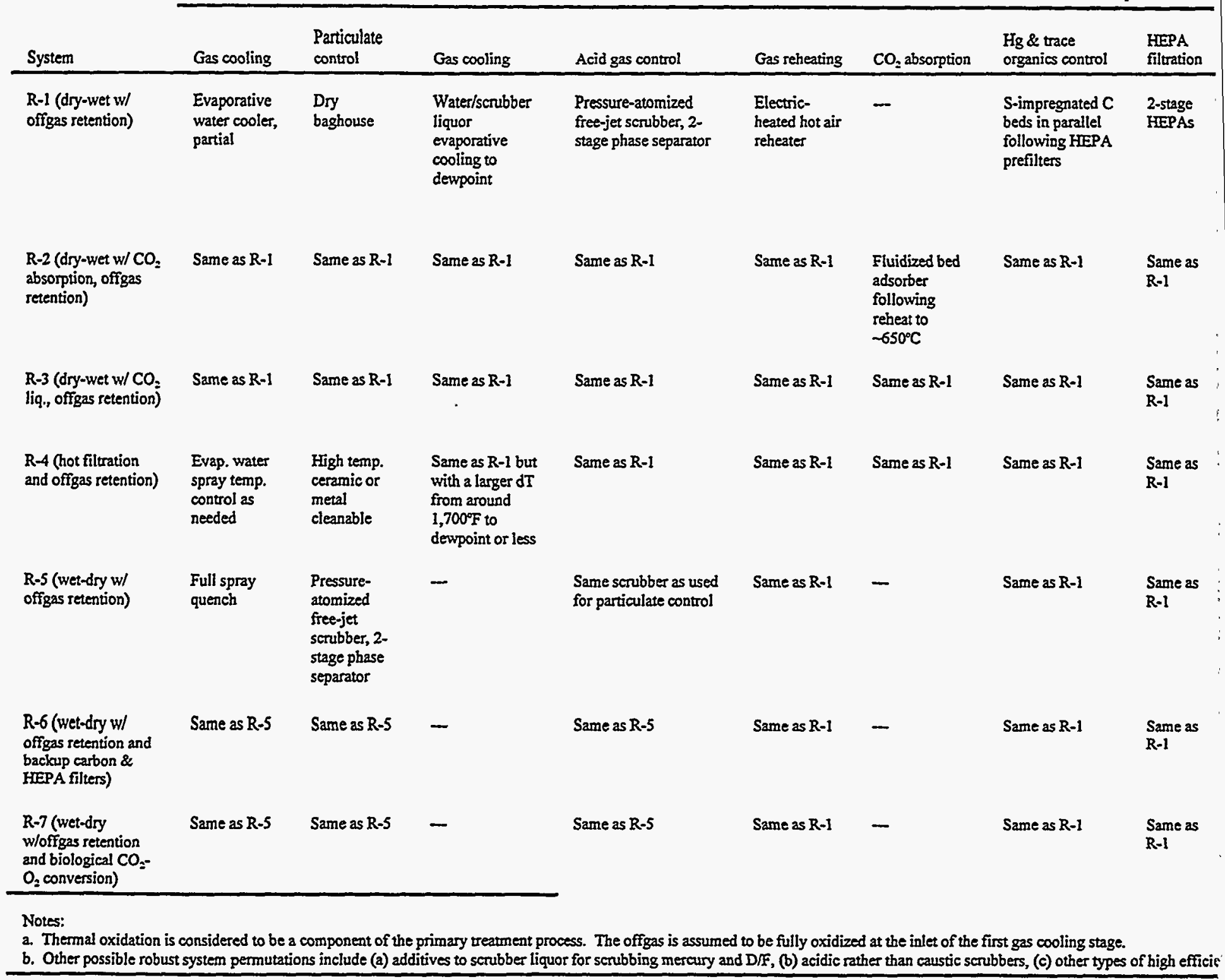




\begin{tabular}{|c|c|c|c|c|c|}
\hline $\mathrm{NO}_{x}$ control & Continuous monitoring & $\mathrm{CO}_{2}$ removal & Offgas retention & Other & Comments \\
\hline $\begin{array}{l}\mathrm{NH}_{3} \text {-injected SCR } \\
\text { w/ inlet \& outlet } \\
\text { NO } \mathrm{NOMMS}_{x} \text { and } \\
\text { outlet } \mathrm{NH}_{3} \mathrm{CEM}\end{array}$ & $\begin{array}{l}\text { Required: } \mathrm{O}_{3} \mathrm{CO} \text {, } \\
\text { THC, } \mathrm{PM} \text {, } \\
\text { beta/gamma, and } \\
\text { alpha; } \\
\text { Optional (included): } \\
\mathrm{CO}_{3} \mathrm{HCl}\end{array}$ & - & $\begin{array}{l}\text { With and without: } \\
3 \text { tanks: } 1 \text { for filling, } 1 \text { for } \\
\text { analysis hold, } 1 \text { for } \\
\text { standby/emptying }\end{array}$ & & $\begin{array}{l}\text { Similar to ITTS A-1 except for placement of HEPAs and } \\
\text { C filter, and offgas retention. Retained gas that cannot } \\
\text { be released must be recycled or treated in separate gas } \\
\text { treatment train (such as low-T Thermatrix, catalytic, or } \\
\text { corona oxidizer, venturi/packed bed, reheater, treated } \\
\text { charcoal, HEPAS, then back to retention tanks or at least } \\
\text { to CEMs }\end{array}$ \\
\hline Same as R-1 & $\begin{array}{l}\text { Same as } \mathrm{R}-1 \text { with } \\
\text { addition of } \mathrm{CO}_{2} \\
\text { monitor upstream of } \\
\mathrm{CO}_{2} \text { adsorber }\end{array}$ & Same as R-I & Same as R-1 & & $\begin{array}{l}\text { Same as } \mathrm{R}-1 \text { except added } \mathrm{CO}_{2} \text { absorption per ITTS } \mathrm{C} \text { - } \\
2 \text {, with } 2 \text { options: leave } \mathrm{CaCO}_{3} \text { in solid form, or } \\
\text { regenerate } \mathrm{CaO} \text { following analysis and acceptance of } \\
\mathrm{CaCO}_{3} \text { in separate calciner, instrumentation, controls, } \\
\text { stack. }\end{array}$ \\
\hline Same as R-1 & Same as R-2 & $\begin{array}{l}\text { Low-pressure } \mathrm{CO}_{2} \\
\text { liquefaction per } \\
\text { Stull } 1992\end{array}$ & Same as R-1 & & $\begin{array}{l}\text { Same as R-1 except add } \mathrm{CO}_{2} \text { liquefaction (Stull 1992) } \\
\text { followed by } \mathrm{CO}_{2} \text { analysis, acceptance, and re- } \\
\text { evaporation or solidification. }\end{array}$ \\
\hline Same as R-1 & Same as R-1 & Same as R-1 & Same as R-1 & & $\begin{array}{l}\text { Same as R-1 except replace baghouse with high } \\
\text { temperature ceramic or metal filter, and adjust offgas } \\
\text { cooling demands accordingly. }\end{array}$ \\
\hline Same as R-I & Same as R-1 & - & Same as R-1 & & Wet/dry equivalent to R-1 with offgas retention \\
\hline Same as R-1 & Same as R-1 & - & $\begin{array}{l}\text { Same as R-1 w/o offgas } \\
\text { retention }\end{array}$ & $\begin{array}{l}\text { Carbon and } \\
\text { HEPA filters }\end{array}$ & $\begin{array}{l}\text { Wet/dry equivalent to R-1 without offgas retention and } \\
\text { with backup carbon and HEPA filters }\end{array}$ \\
\hline Same as R-1 & Same as R-1 & - & $\begin{array}{l}\text { Same as R-1 w/o offgas } \\
\text { retention }\end{array}$ & $\begin{array}{l}\text { Biological } \\
\mathrm{CO}_{2} \text { to } \mathrm{O}_{2} \\
\text { conversion }\end{array}$ & $\begin{array}{l}\text { Wet/dry equivalent to } \mathrm{R}-1 \text { without offgas retention and } \\
\text { with biological } \mathrm{CO}_{2} \text { to } \mathrm{O}_{2} \text { conversion (perhaps remove } \\
\text { offgas retention and use the } \mathrm{CO}-\mathrm{O}_{2} \text { conversion chamber } \\
\text { for offgas holdup due to residence time) }\end{array}$ \\
\hline
\end{tabular}


Table 4-3. Comparison of dry-wet and wet-dry APC systems.

\begin{tabular}{|c|c|}
\hline $\begin{array}{l}\text { Offgas } \\
\text { system }\end{array}$ & Advantages \\
\hline \multirow[t]{3}{*}{ Dry-wet } & $\begin{array}{l}\text { Separate dry particulate (radionuclide/hazardous metal) and } \\
\text { aqueous salt solutions can simplify secondary handling and } \\
\text { treatment for each of these streams. The dry particulate can be } \\
\text { recycled to another thermal process or solidified in cement } \\
\text { technologies such as polyethylene or sulfur polymer cement that } \\
\text { do not allow water. The aqueous salt streams with essentially } \\
\text { no radionuclides or solids can be treated or disposed of more } \\
\text { easily without the radionuclides or toxic metals. }\end{array}$ \\
\hline & $\begin{array}{l}\text { Wet scrubber criticality is not a concem because, essentially, all } \\
\text { fissile radionuclides are removed in the baghouse. }\end{array}$ \\
\hline & $\begin{array}{l}\text { Volume reduction of the dry and aqueous secondary wastes is } \\
\text { easier. Recycling dry particulate can significantly reduce the } \\
\text { volume of this waste. Evaporation of the scrubber effluent } \\
\text { (made more easy by removal of most radionuclides and most } \\
\text { particulate) can significantly reduce the volume of this waste. }\end{array}$ \\
\hline
\end{tabular}

Disadvantages

Potential for dispersible fines in the baghouse catch and potential worker exposure and contamination control issues during baghouse/filter maintenance.

Tighter process control is required in the partial quench step upstream of the baghouse/filter to prevent moisture condensation or moisture droplets, corrosion, or thermal damage to the bags/filters.

The typical cooling temperature of $\sim 300^{\circ} \mathrm{F}$ is not cool enough to prevent some D/F formation in the particulate filter according to some recent studies (Soelberg 1996). However, this potential is minimized by using high temperature filtration. Also, if carbon adsorption is used for trace pollutant control, the carbon should remove D/F formed.

There is still barrier filtration in the event of a power failure.

Wet-dry Simpler gas cleaning by rapidly cooling the gas to the dewpoint (or lower, condensing some water out of the offgas), and combining acid gas and particulate removal functions.

No dispersible fines are produced, unless treatment of the scrubber effluent requires precipitation, filtration or drying.

Minimizes $\mathrm{D} / \mathrm{F}$ formation by rapidly quenching the offgas to under $200^{\circ} \mathrm{F}$.

Marginally better $\mathrm{Hg}$ control upstream of the charcoal filters because of the initial quench to a lower gas temperature.

Produces an aqueous mixed waste scrubber secondary stream that could contain fissile radionuclides, toxic metals, and halogen salts, producing more treatment challenges prior to disposal. This lessens the potential for recycling this waste stream to the primary treatment unit or evaporation to reduce secondary waste volume.

The performance of the free-jet scrubber strongly depends on constant offgas flowrate, composition, temperature, and differential pressure, which may be difficult to control for different heterogeneous waste input streams.

Increased potential for problems related to dissolved or suspended particulate in the scrub solution-nozzle erosion/plugging, sludge deposition, nuclear criticality, and residual submicron particulate in the gas remaining from evaporation of scrub solution droplets.

A power failure or other upset that affects the scrubber spray can significantly reduce particulate removal capability.

- It includes primarily standard, available, off-the-shelf equipment so it has less technical uncertainty.

- $\quad$ Since it uses dry particulate filtration followed by wet acid gas scrubbing, the dry particulate secondary waste is separate from the aqueous scrubber solution secondary waste. This simplifies secondary waste handling and treatment, reduces the risk of criticality in the wet scrubber by removing nearly all fissile radionuclides in baghouse, and contains barrier filtration that will still protect the HEPAs and prevent any additional PM, metals, and radionuclide emissions in the event of a power failure.

- The wet scrubber is a state-of-the-art, high-performance free-jet scrubber which has been used in several other mixed waste treatment designs and facilities. The combination of upfront particle 


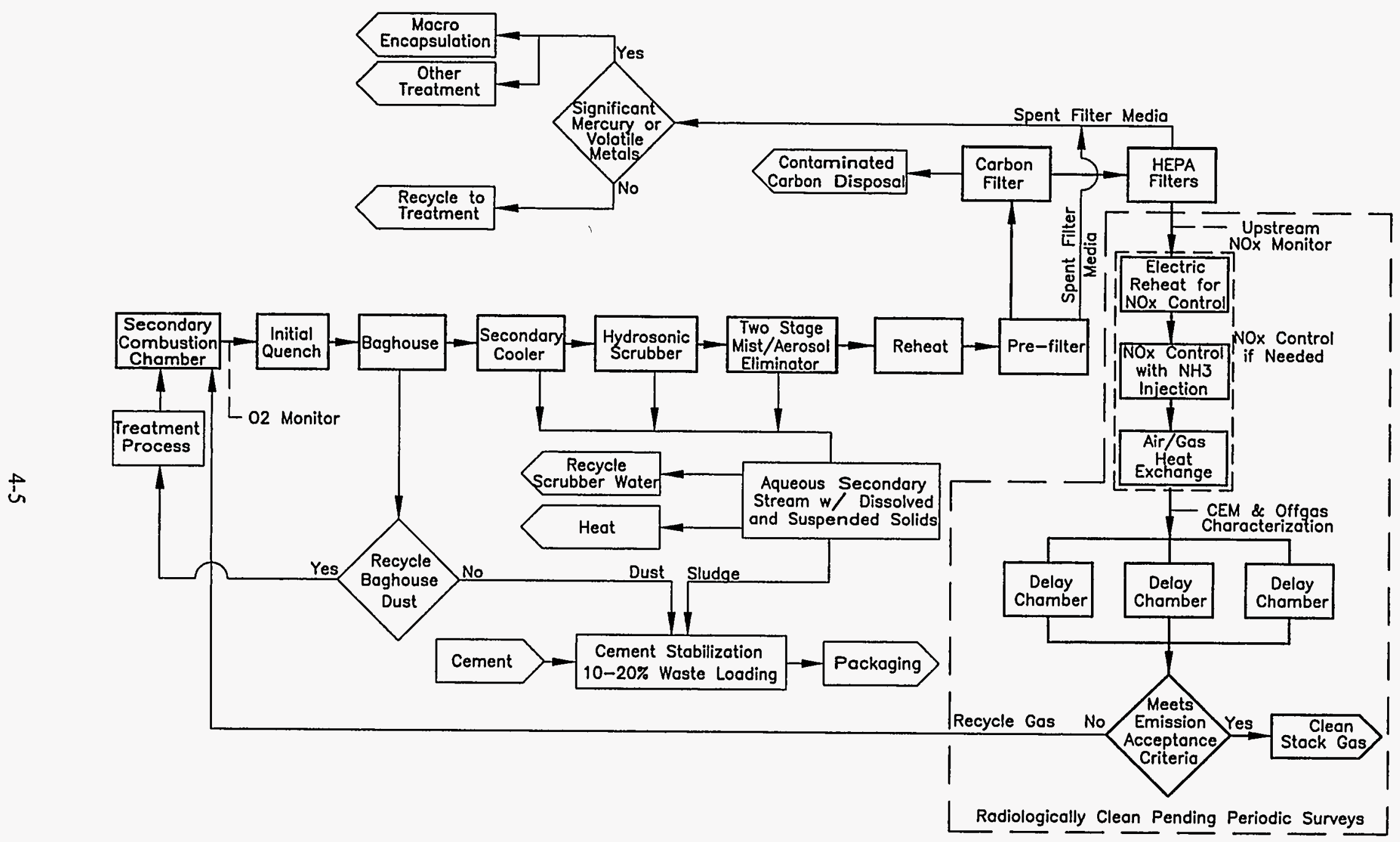

Figure 4-1. Schematic of the R-1 conceptual offgas system. 
removal, offgas cooling below its dewpoint, and the use of an air-atomized rather than steamatomized scrubber may improve scrubber performance and reduce some of the problems experienced with high offgas temperatures, moisture loading, and residual aerosols in the offgas at other DOE facilities.

- The offgas reheater downstream of the wet scrubber blends heated ambient air with the saturated offgas to raise the offgas temperature and also lower the dewpoint by dilution. This has the advantages of (a) maintaining the heating elements in a radioactively clean environment, facilitating easier maintenance, (b) preventing fouling of the heating elements from aerosols that may still be in the offgas in small amounts, and (c) enabling a lower net reheat temperature increase for the offgas by lowering the dewpoint somewhat. Some of the problems experienced with offgas reheating at the CIF incinerator may be avoided with this design.

- Following a prefilter and the first-stage HEPA, Hg and trace organics are removed using sulfurimpregnated carbon. While relatively new, several vendors provide commercial packed beds with commercially-produced carbon for this purpose.

- Two-stage HEPA filtration is a standard for mixed waste treatment. Each filter is designed for certification testing to enable the maximum credit for combined filtration efficiency.

- $\quad \mathrm{NO}_{\mathrm{x}}$ destruction using SCR technology is included as an option for removing $\mathrm{NO}_{\mathrm{x}}$ in excess of allowable limits. The SCR technology is not expected to be needed unless a highly oxidizing plasma torch process that uses nitrogen as the torch gas is the primary treatment unit.

- Offgas retention tanks are included as an option to evaluate the costs and benefits of retaining the offgas long enough to complete detailed analyses that demonstrate that the offgas being delivered to each tank meets regulatory limits.

\subsection{Offgas System Functional Description}

To comply with emission regulations listed in Section 2, offgas systems need to include particulate control, acid gas control, $\mathrm{Hg}$ and trace organics removal, HEPA filtration, and in some cases $\mathrm{NO}_{\mathrm{x}}$ removal. Many conditioning steps are required to prepare the offgas for the gas cleaning steps, enable the gas cleaning steps to operate effectively, and prevent damage to gas cleaning and other downstream equipment. Conditioning steps include initial offgas cooling of the hot $\left(2,200^{\circ} \mathrm{F}\right) \mathrm{SCC}$ outlet gas, secondary gas cooling (downstream of dry particulate removal if it is used), and offgas reheating to temperatures above the dewpoint or to reaction temperatures for such processes as $\mathrm{NO}_{\mathrm{x}}$ control or $\mathrm{CO}_{2}$ absorption. It may be desirable or necessary to use offgas retention tanks for preventing any offgas release to the atmosphere until it has been adequately analyzed and demonstrated to meet emission limits. Continuous emission monitoring for offgas flowrate, $\mathrm{O}_{2}, \mathrm{CO}, \mathrm{CO}_{2}, \mathrm{NO}, \mathrm{THC}, \mathrm{HCl}$, and $\mathrm{PM}$ is important to ensure that emission limits are being met or indicating when significant changes occur during non-normal or upset conditions. 


\subsubsection{Initial Offgas Cooling}

The high temperature of the offgas exiting the SCC must be reduced to enable downstream control of particulates, metals, and acid gases, and to prevent thermal damage of the downstream equipment. Design objectives for offgas cooling include:

- Have sufficient control over the quench process to enable rapid response to temperature, flowrate, and composition variations of the offgas.

- Cool as rapidly as possible to reduce residence time in the temperature range in which $\mathrm{D} / \mathrm{F}$ may be formed if D/F precursors are present. D/F precursors, if present in sufficient amounts, can cause unacceptable $\mathrm{D} / \mathrm{F}$ emissions if allowed sufficient time to form in the temperature window of approximately $450-750^{\circ} \mathrm{F}$, especially in the presence of significant catalyzing surface area presented by such equipment as heat exchangers, or simply on the PM entrained in the offgas.

- Minimize the potential for solid or liquid deposits that may impair offgas cooling or cause flow restrictions.

- Minimize total offgas flowrate through the remainder of the system to reduce equipment size and to have lower flowrates of offgas out the stack.

Heat recovery, though normally a good practice to increase energy efficiency and reduce operating costs, is a very low consideration compared to the above criteria. Heat exchangers such as heat recovery boilers to perform offgas cooling are not recommended because of the (a) potential for process upsets from fouling or corrosion of heat transfer surfaces, and (b) longer residence times in the D/Fforming temperature window.

The recommended choice for offgas cooling is water or scrubber solution spray and evaporation. While dilution with cooler air or recycled offgas is also acceptable, this method can increase the mass flowrate of the offgas mixture by 10 times or more depending on the dilution ratio. Depending on the downstream operations, the offgas may be cooled to a temperature well above its dewpoint (around $300^{\circ} \mathrm{F}$ for particulate control in a baghouse), at its dewpoint (typically resulting in a saturated gas temperature of around $170-180^{\circ} \mathrm{F}$ ), or below its initial dewpoint. Cooling the offgas with a water or scrubber solution spray to a temperature below the initial dewpoint is possible if there is a separate scrubber liquor cooling system. This subcooling is sometimes desired to reduce corrosion, agglomerate condensed particles for more efficient removal, avoid D/F formation, reduce the offgas volumetric flowrate, and condense water vapor that may contain tritium out of the gas stream. Cooling of the scrubber solution avoids the need to discharge large amounts of warm scrubber solution to remove heat from the offgas. However, the cooling cost using chiller units can be high.

\subsubsection{Particulate, Toxic Metals, and Radionuclide Control}

Particulate, toxic metals, and radionuclide control are grouped together because, with a few exceptions, they are mostly in solid form at typical cooled offgas temperatures between $120-300^{\circ} \mathrm{F}$, and can be removed with efficient particulate control equipment. This temperature range is sufficiently low that even the more volatile isotopes of $\mathrm{Cs}, \mathrm{Co}, \mathrm{K}$, and $\mathrm{Zn}$ are mostly condensed into particulate form. 
Exceptions include $\mathrm{Hg}$ and the isotopes $\mathrm{C}-14, \mathrm{H}-3$, and I-129, which can exist as gaseous species at temperatures between $120-300^{\circ} \mathrm{F}$. Various radionuclides and their relative volatilities include:

$\begin{array}{ll}\text { Isotope } & \text { Volatility } \\ \text { Am-241 } & \begin{array}{l}\text { Non-volatile } \\ \text { Pu-238 through Pu-241 } \\ \text { Non-volatile } \\ \text { Non2 through U-238 }\end{array} \\ \text { Non-volatile } \\ \text { Ba-137 } & \text { Low volatile } \\ \text { Co-60 } & \text { Low volatile } \\ \text { Sr-90 } & \text { Low volatile } \\ \text { Cs-137 } & \text { Semi-volatile } \\ \text { Y-90 } & \text { Semi-volatile } \\ \mathrm{Zn}-65 & \text { Semi-volatile } \\ \text { C-14 } & \text { Volatile as } \mathrm{CO}_{2} \\ \mathrm{H}-3 & \text { Volatile as } \mathrm{H}_{2} \mathrm{O} \\ \mathrm{I}-129 & \text { Volatile as } \mathrm{HI}_{2} \mathrm{I}_{2}\end{array}$

These volatility indications are qualitative, since the actual volatility of any element will vary depending on the speciation of that element between its pure form and compounds such as oxides and chlorides.

Design objectives for particulate, toxic metals, and radionuclide control include:

- Meet expected emission limits

- Minimize the amounts of offgas secondary streams that are radioactive

- Minimize amounts of dispersible (dusty) secondary streams

- Optimize the handling and treatability of the secondary streams, including avoiding liquid mixed waste streams and maximizing recycle.

Only high efficiency technologies should be considered. The foremost dry technologies (when the offgas temperature is higher than the moisture saturation temperature) include pulse-jet baghouses that can operate at offgas temperatures up to around $500^{\circ} \mathrm{F}$, and higher temperature ceramic and sintered metal filters that can operate up to around $1,700^{\circ} \mathrm{F}$. A schematic of a pulse-jet baghouse is shown in Figure 4-2. Higher temperature filters have been and are being tested for DOE use (Christian 1978, EER 1992, and MSE 1995), and have been used in Germany, Austria, and Japan for low-level waste incineration using the Karlsruhe-type shaft incinerator (IAEA 1989, Soelberg 1996a, and Dirks 1996). High temperature filters need further development and demonstration testing to evaluate control efficiencies, operating lifetime, pressure drop, thermal tolerance, durability, and fouling potential. 


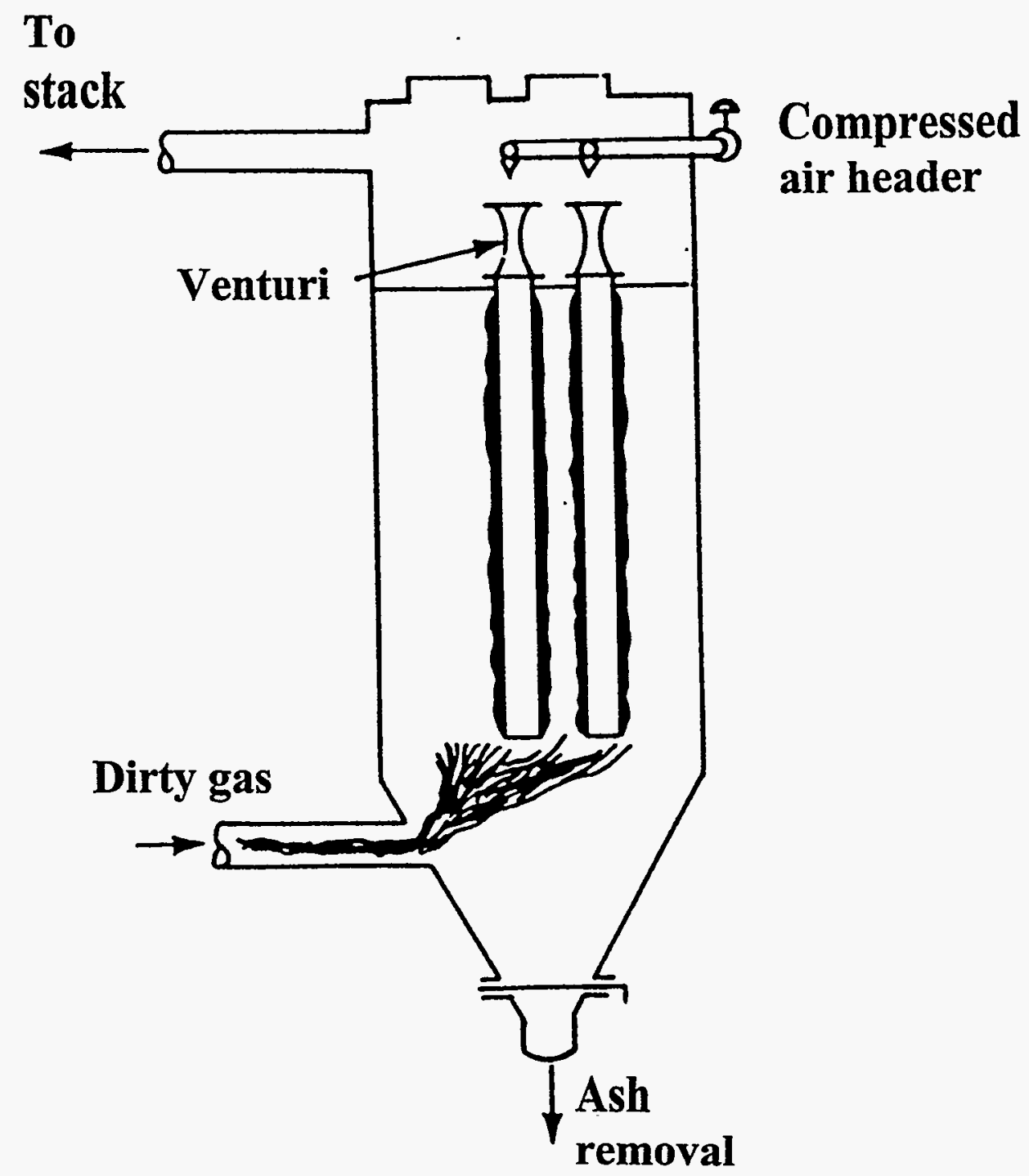

Figure 4-2. Schematic of a pulse-jet baghouse (Wark 1981). 
A leading wet scrubbing method is free-jet scrubbing. This technology has been specified, tested, or implemented in several DOE waste treatment testing and operating facilities including the Mountain States Energy (MSE) Plasma Arc Centrifugal Treatment furnace test facility (MSE 1994 and 1995), the Savannah River Site (SRS) Consolidated Incineration Facility (CIF), and the Defense Waste Processing Facility (DWPF). A schematic of a free-jet scrubber is shown in Figure 4-3. Other potential high efficiency wet scrubbing technologies include wet electrostatic precipitators. Venturi scrubbers and packed bed scrubbers, commonly used in nonradioactive thermal processes, are not recommended as stand-alone wet scrubbing devices because of their lower scrubbing efficiencies (unless the pressure drop for venturi scrubbers is very high, in excess of 60 in. water).

\subsubsection{Acid Gas Control}

Acid gases, including $\mathrm{HCl}$ and $\mathrm{SO}_{2}$, will be produced from waste materials that contain chlorides and sulfates. Design objectives for acid gas control include:

- Meet expected control efficiency and emission limits

- Minimize the amounts of offgas secondary streams that are radioactive

- Optimize the treatability of the secondary streams, including avoiding liquid mixed waste streams

- Have minimal impact on system backpressure and flowrates.

If dry particulate filtration is used for particulate control upstream of the acid gas control, then such acid gas scrubbing technologies as packed bed scrubbers are acceptable. A total quench to the saturation temperature is necessary at the inlet to the scrubber. Assuming that the baghouse can efficiently filter particulate and radionuclides, the scrubber blowdown may be below regulatory limits for toxic metals and radionuclides, though it will contain high chloride levels from some waste streams. Analysis of the blowdown for toxic metals and radioactivity is expected to be required.

If wet scrubbing for particulate is used immediately following thermal oxidation and gas cooling for particulate control, then the acid gas control can occur in the same unit operation. Free-jet scrubber systems are very efficient for both particulate and acid gases. Other wet scrubbing technologies such as wet electrostatic precipitators may require combination in series with a unit such as a packed bed scrubber to provide adequate acid gas control and improve particulate control.

\subsubsection{Mercury and Trace Organics Control}

Along with any trace volatile and semivolatile organics present in the offgas, such as D/F, $\mathrm{Hg}$ may not be efficiently controlled upstream of the particulate capture and acid gas control steps. Carbon adsorption is specified in the proposed MACT Rule for both $\mathrm{Hg}$ and $\mathrm{D} / \mathrm{F}$ control. Relevant issues regarding carbon adsorption include the optimum operating temperature for efficient adsorption, the form and type of carbon, adsorption-improving additives such as sulfur for mercury control, spent carbon disposal, and fire prevention. With reasonably efficient carbon adsorption for mercury and trace organics, a mixed waste treatment facility should readily meet emission limits for these pollutants. 


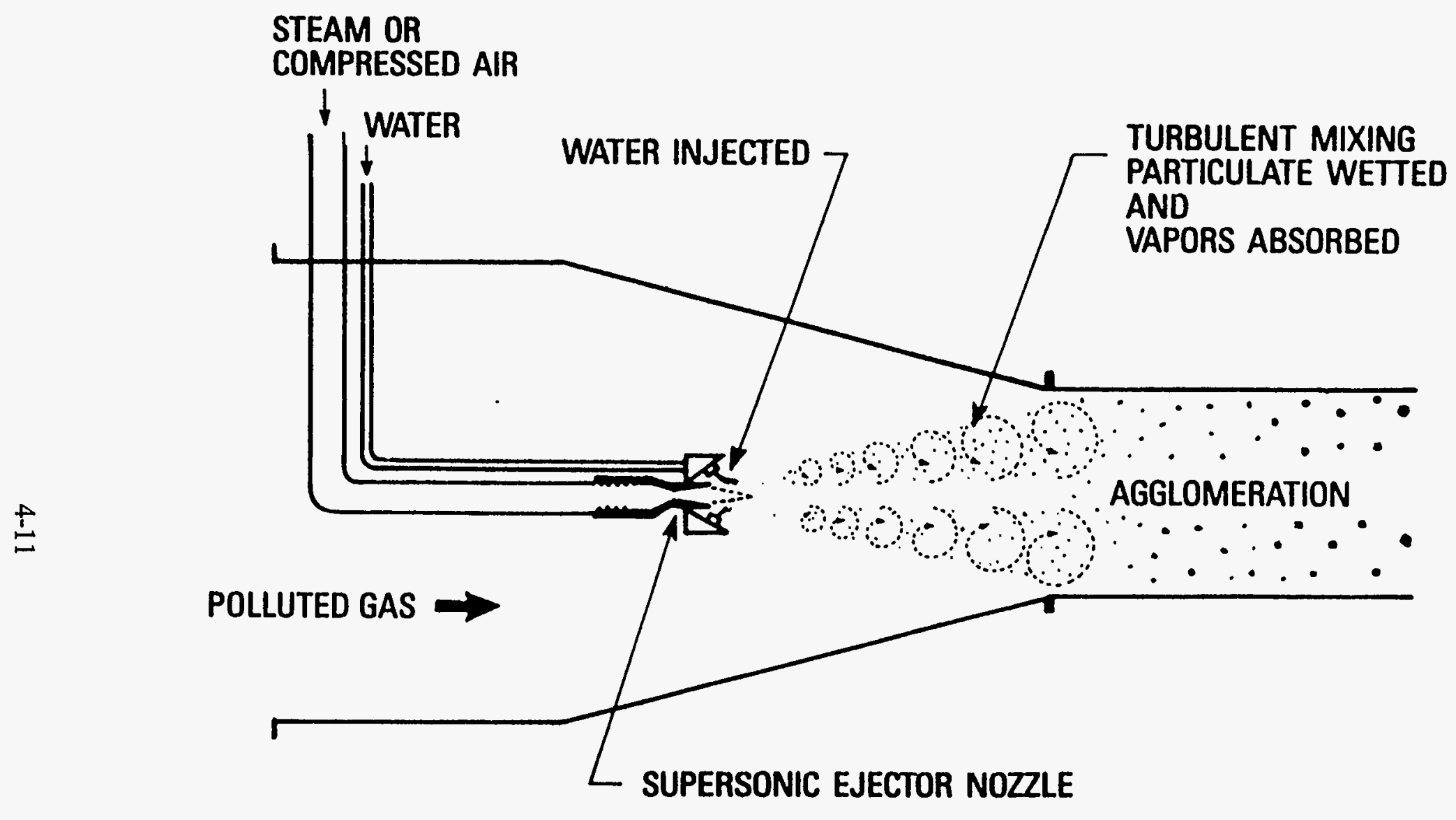

Figure 4-3. Schematic of free-jet scrubber. 
The type of $\mathrm{Hg}$ control depends on the amount of $\mathrm{Hg}$ and other elements in the waste feed. Because of the high volatility of elemental $\mathrm{Hg}$ and its compounds, all $\mathrm{Hg}$ fed to the primary thermal treatment system is generally assumed to volatilize as elemental $\mathrm{Hg}, \mathrm{HgCl}_{2}$, and $\mathrm{HgO}$. Upon cooling, some volatilized $\mathrm{Hg}$ species may condense if sufficient amounts are present to exceed vapor pressures at the quench temperatures. $\mathrm{HgCl}_{2}$ is readily soluble in water and may be captured in an aqueous scrubber system such as the free-jet scrubber.

Even if only trace amounts of $\mathrm{Hg}$ are processed in the thermal treatment system, $\mathrm{Hg}$ removal processes are expected to be necessary for meeting strict $\mathrm{Hg}$ emission limits. A new technology uses amalgamation of mercury on gold supported by a substrate to remove mercury and mercury chloride vapors (Roberts 1995). This technology has not been as proven as sulfur-impregnated carbon adsorption, so only sulfur-impregnated carbon adsorption is included in this study.

The spent carbon will be a secondary waste. Spent carbon that does not contain significant amounts of $\mathrm{Hg}$ may be recycled to the primary treatment process, even if small amounts of $\mathrm{D} / \mathrm{F}$ and other organics are present. However, large amounts of $\mathrm{Hg}$ may build up in the system if spent carbon containing large amounts of $\mathrm{Hg}$ are recycled. There is presently not an acceptable disposal alternative for spent carbon that contains $\mathrm{Hg}$ and radioactive contamination. The disposal issue is significant and must be resolved for the use of carbon adsorption in mixed waste treatment.

\subsubsection{HEPA Filtration}

Particulate control efficiencies for baghouses and for free-jet scrubbers can exceed $99.9 \%$. Other offgas equipment including evaporative coolers, acid gas scrubbers, carbon adsorbers, and HEPA prefilters can also exhibit some particulate removal capability. The combined filtration capability of all equipment upstream of the HEPA filters will likely far exceed $99.9 \%$ efficiency. However, in a nuclear facility, final HEPA filtration is required to control any small remaining amounts of particulate for radionuclide and toxic metals control. Frequently, HEPA prefilters, HEPA filters, and carbon adsorption beds can be placed in a single housing with separate compartments for maintenance purposes. An example of this configuration is shown in Figure 4-4.

Spent HEPA filters will be a secondary waste, which may be recycled to the melter, processed in a low-temperature glass melter, or macroencapsulated. Recycle to a melter is possible as long as there is not a large buildup of $\mathrm{Hg}$ or difficult-to-control fines in the system. Because of the probable combined particulate removal efficiency of the offgas system upstream of the HEPA filters, the HEPAs for a well designed and operated offgas system should not require frequent replacement.

\subsection{6 $\mathrm{NO}_{\mathrm{x}}$ Control}

Secondary abatement technologies used for controlling $\mathrm{NO}_{\mathrm{x}}$ emissions can be described as dry or wet processes and catalytic or noncatalytic processes (Dalton 1992). Dry abatement processes convert $\mathrm{NO}_{x}$ to $\mathrm{N}_{2}$ by reacting the $\mathrm{NO}_{x}$ with other gaseous reagents. Dry abatement technologies include selective catalytic and noncatalytic reduction as well as nonselective catalytic and noncatalytic reduction processes. The selective reduction processes react $\mathrm{NO}_{\mathrm{x}}$ with ammonia or other nitrogen compounds. The catalytic process can achieve a destruction efficiency between 85 to $95 \%$ while operating at temperatures between $500-800^{\circ} \mathrm{F}$. 


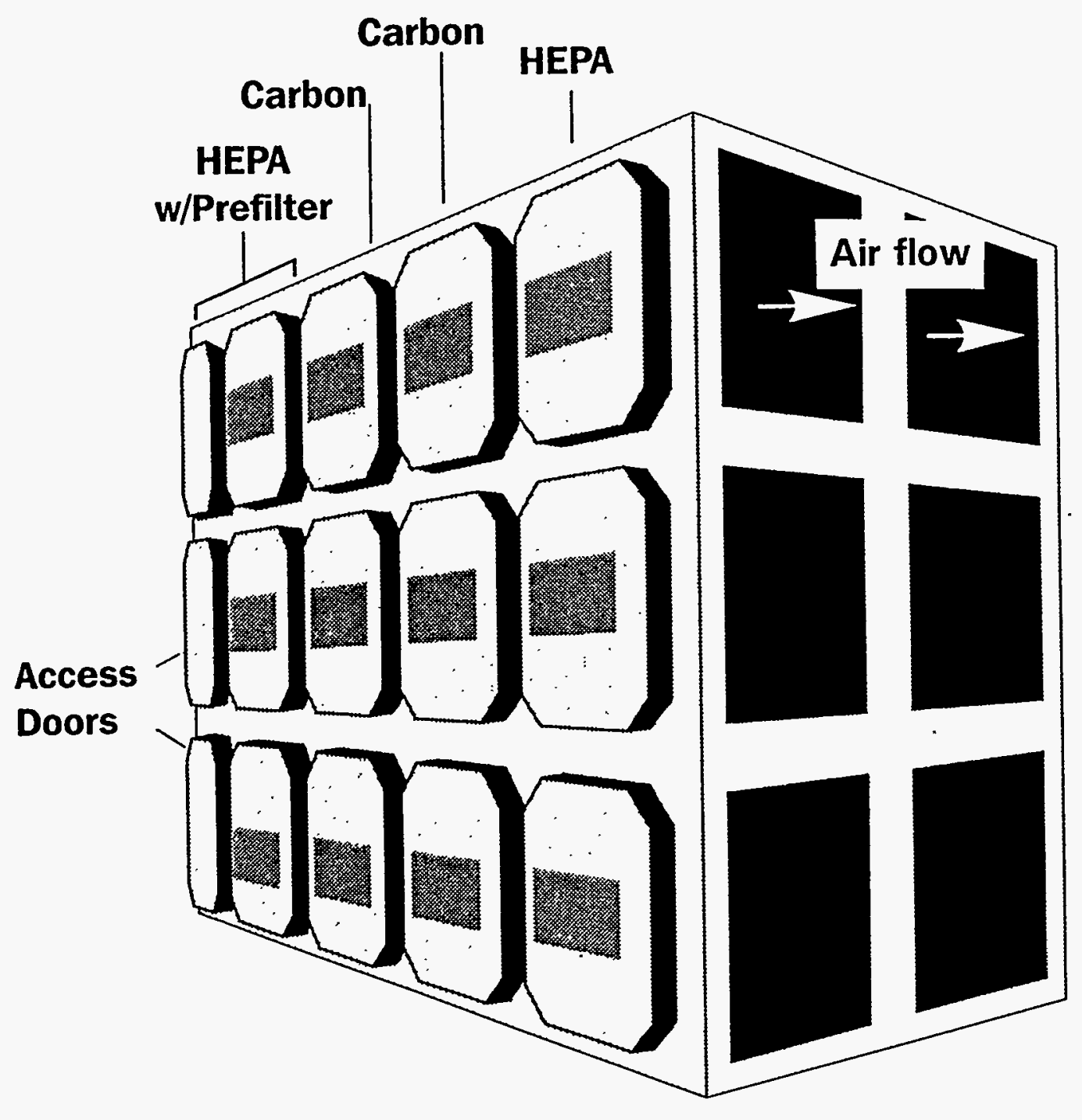

Figure 4-4. Offgas containment housing consisting of HEPA prefilter, HEPA filters, and carbon beds with maintenance access doors. 
Noncatalytic process achieves destruction efficiencies of up to $70-80 \%$ at temperatures between 1,600 and $2,200^{\circ} \mathrm{F}$. In nonselective processes, a gaseous fuel is mixed with gas containing the $\mathrm{NO}_{\mathrm{x}}$ and burned to convert $\mathrm{NO}_{\mathrm{x}}$ to nitrogen and water or carbon dioxide. The fuel (hydrogen, methane, or other hydrocarbons) is not selective and will react with other constituents, primarily oxygen.

\subsubsection{Continuous Monitoring}

Continuous emissions monitoring is assumed based on the requirements of the proposed MACT Rule, with some assumed additions to meet expected permit requirements and for some specific process monitoring and control. Continuous emission monitors (CEMs) included in the high-performance systems are summarized in Table 4-4. Continuous monitoring for $\mathrm{Hg}$, metals, and D/F is not included in any of the high-performance offgas systems because these monitors are still developmental, have not yet met EPA performance specifications for use as CEMs, and do not meet reliability requirements. While the draft proposed MACT Rule specifies the use of continuous monitoring for Hg, subsequent EPA documents report that $\mathrm{Hg}$ CEMs will not be required (EPA 1997b). The alternative of $\mathrm{Hg}$ feed limits and appropriate monitoring of carbon bed and other systems is recommended at this time instead of $\mathrm{Hg}$ monitoring.

Demonstrations of continuous multiple metals CEMs have also shown that they do not presently meet performance specifications. The alternative of metals feed limits and appropriate monitoring of scrubber, HEPA, and other systems is recommended instead of continuous metals monitoring. Continuous D/F monitors are even more developmental than $\mathrm{Hg}$ and metals CEMs. EPA may eventually identify a surrogate such as $\mathrm{CO}, \mathrm{THC}$, or a specific hydrocarbon species for D/F and other organic PICs rather than require continuous $\mathrm{D} / \mathrm{F}$ monitoring.

\subsubsection{Zero Emissions Approach}

Operation of thermal and nonthermal treatment systems with "zero emissions" is not realistically possible because of the generation of effluent gas containing typically noncondensible gases such as $\mathrm{N}_{2}$ and $\mathrm{O}_{2}$. The most technically feasible approach for near "zero emissions" or zero uncontrollable emissions is to minimize the volume of offgas to the extent possible, and then prevent the release of the offgas to the atmosphere until adequate analysis is completed that demonstrates that pollutant emissions are within regulatory limits. Methods that can be used (and are included in various high-performance offgas system alternatives) to achieve this include using:

- Oxygen instead of air for combustion

- Electrical heat input for treating low-heating-value wastes rather than fossil fuel combustion

- Water spray evaporation for cooling rather than air dilution cooling

- Offgas retention until analyses are complete

- $\mathrm{CO}_{2}$ absorption or removal via liquefaction or through photosynthesis.

These measures to approach a "zero emissions" philosophy have not been used significantly in DOE or non-DOE facilities, largely because of high additional costs that were not justified. The implementation of a "zero emissions" philosophy depends on stakeholder and operator requirements as well as cost/benefit evaluations. 
Table 4-4. Continuous emissions monitoring for the high-performance offgas systems.

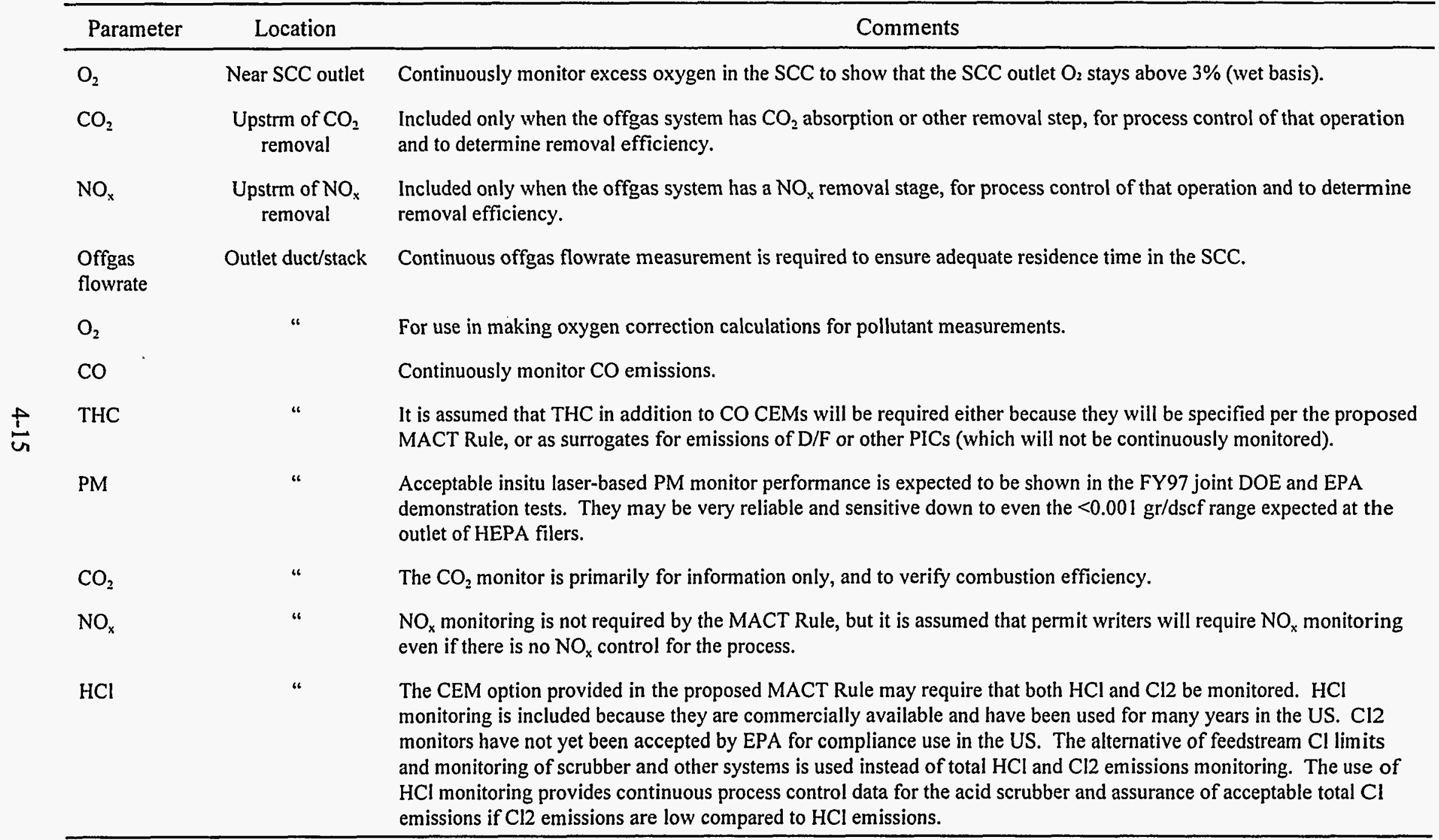




\section{APCS PROCESS SIMULATION}

System process simulations using a computational model allow quick comparisons of different design alternatives and evaluations of whether desired objectives can be achieved for a given design early in the design process. ASPEN PLUS (hereafter referred to as ASPEN) is a process simulation code that was used to model the selected APCS. ASPEN calculates mass and energy balances around each unit operation using thermodynamic equilibrium calculations based on chemical reaction and equilibrium data specified by the user or retrieved from an extensive database. ASPEN can also perform nonequilibrium calculations specified by the user, and model solids handling processes such as particulate filtration that are not based on thermodynamic equilibria. These features make ASPEN a powerful tool for evaluating APCS design.

\subsection{APCS Unit Operations}

The operating conditions, equipment specifications, and any performance data used to define them for each unit operation are presented below. More detailed information based on discussions with vendors is summarized in Appendix C.

\subsubsection{Partial Quench}

The purpose of the partial quench is to cool the offgas (using water spray evaporation) to an acceptable temperature before it enters the baghouse. The partial quench was operated adiabatically at near atmospheric pressure ( $12.5 \mathrm{psia}$ at the elevation of the INEEL). Water was added at $60^{\circ} \mathrm{F}$ to the $2,200^{\circ} \mathrm{F} \mathrm{SCC}$ outlet offgas. Water addition was limited to achieve an exit gas temperature of $300^{\circ} \mathrm{F}$, still above the moisture saturation temperature. The temperature was still high enough to evaporate all water spray droplets and prevent water condensation in the baghouse that could blind the filter bags, increase corrosion, and cause agglomeration of ash collected in the baghouse.

\subsubsection{Baghouse}

The ASPEN block FABFL is specifically designed to model a baghouse. When used in the design mode, the block can calculate the total number of cells given the number of bags in a cell, the diameter and surface area of a bag, the average and maximum pressure drop across a bag, and a resistance coefficient indicative of the particle size filtration expected across the bag.

For design purposes, the bag diameter was specified to be $0.52 \mathrm{ft}$ and the bag surface area was $19.6 \mathrm{ft}^{2}$ with 12 bags per cell. A resistance coefficient of 300,000 was assumed, reflecting the high efficiency for removing submicron particles. Minimum and maximum pressure drops across the bags are 4 and 4.5 in. water. Information from BHA Group stated that a particulate removal efficiency of $99.983 \%$ for $0.5 \mu \mathrm{m}$ can be achieved for high efficiency bags. A more conservative removal efficiency of $99.9 \%$ for particles equal to or larger than $0.5 \mu \mathrm{m}$ particles was assumed in the process simulation model. A removal efficiency of $99 \%$ was assumed for particles less than $0.5 \mu \mathrm{m}$.

\subsubsection{Full Quench}

The second and final quench was assumed to be operated adiabatically with no significant pressure drop. The rate of $60^{\circ} \mathrm{F}$ water addition was adjusted to ensure a saturated vapor leaving the unit 
with no excess liquid water. The amount of water required and the final temperature of the offgas leaving the final quench depend on the water content of the offgas entering the unit.

\subsubsection{Free-jet Scrubber}

This high-efficiency, low-pressure drop scrubber can efficiently remove acid gases (represented by $\mathrm{SO}_{2}$ and $\mathrm{HCl}$ ) and particulate in the offgas using caustic scrubber solution that is air-atomized into the gas stream. A $1 \%$ excess $\mathrm{NaOH}$ was added in addition to the amount of $\mathrm{NaOH}$ needed to remove $99 \%$ of the $\mathrm{SO}_{2}$ and $99.9 \%$ of the $\mathrm{HCl}$. These removal efficiencies are readily achievable according to vendor information and empirical data. The added $\mathrm{NaOH}$ was sufficient to maintain $\mathrm{pH}$ between 8 and 10 . Unreacted acid gases remained in the offgas. It was assumed that the scrubber can remove $99.9 \%$ of the $\mathrm{HgCl}_{2}$ present in the offgas, but none of the elemental $\mathrm{Hg}$ vapor. This assumption has no supporting vendor information, but empirical data indicates that overall $\mathrm{Hg}$ removal efficiencies exceeding $99 \%$ are possible under some wet scrubber conditions (EPA 1997c).

In addition, the scrubber removes a portion of particulate that remains in the offgas following the baghouse. According to vendor specifications, the particulate concentration in the scrubber offgas is a function of the atomizing air mass flowrate (which controls the size of atomized solution droplets) and liquid mass flowrate relative to the mass flowrate of the offgas being scrubbed (liquid surface area to gas volume ratio). It was assumed that all particles greater than $0.5 \mu \mathrm{m}$ still in the offgas entering the free-jet scrubber were removed in the process. Particulate removal efficiency does not decrease at lower offgas flowrates. The scrubber was assumed to operate adiabatically with no significant pressure drop.

Scrub solution was recycled to maintain the liquid flowrate through the scrubber at $60 \mathrm{gpm}$ in the high-flow case and $30 \mathrm{gpm}$ in the low-flow case per vendor specifications. The recycled scrub solution was cooled to $60^{\circ} \mathrm{F}$ by a chiller to cool the offgas below its initial dewpoint and condense some moisture. The offgas was cooled approximately 10 to $15^{\circ} \mathrm{F}$ in the scrubber.

The maximum allowable dissolved salt concentration in the scrubber liquid was specified by the vendor at $10 \mathrm{wt} \%$. Dissolved salts were maintained below this limit by discharging scrub solution in the blowdown. In the high-flow case, there was sufficient water condensate so that no makeup water was necessary to provide scrub solution blowdown. Additional makeup water was necessary for the low-flow case because more $\mathrm{HCl}$ was in the input offgas, so a higher blowdown rate was necessary.

\subsubsection{Offgas Reheat}

The offgas exiting the scrubber is saturated and must be heated above its dewpoint to prevent condensation within the filters. Also, the gas cannot exceed the temperature limit of $200^{\circ} \mathrm{F}$ for the carbon beds. Offgas reheat was achieved by mixing ambient air heated to $1,000^{\circ} \mathrm{F}$ with the offgas. The process simulation considered the possible revolatilization of arsenic, mercury, or selenium in the solid particulate when the offgas is reheated. Volatilization of any other metals was not considered because of their typically low volatilities at temperatures below $200^{\circ} \mathrm{F}$.

Using preheated air to blend with the saturated offgas is unique to this conceptual design, and has not been implemented in any existing DOE mixed waste treatment facilities. Advantages of the preheated air concept include (a) elimination of heater elements in contact with offgas, and (b) lowering of the blended offgas dewpoint. When the heating elements are not in contact with the saturated offgas, 
several potential problems such as corrosion and fouling of the elements from aerosols impacted on the elements are eliminated. Also, any maintenance that is required for the heating elements can be done in an area of lesser contamination than expected for the offgas.

\subsubsection{Prefilter}

The prefilter was modeled using the FABFL block in simulation mode. In this mode, the block can remove particles according to size and removal efficiency specified by the user. Particulate removal efficiency for an Airpure Rigid Pak 95 from Flanders Filter was used to define the prefilter efficiency. The removal efficiency for this type of prefilter is a function of particle size:

$\begin{array}{cc}\text { Particle size } \mu \mathrm{m} & \text { Efficiency.\% } \\ >2 & 100 \\ 0.8 & 95 \\ 0.6 & 90 \\ 0.5 & 87\end{array}$

No information was available for particles below $0.5 \mu \mathrm{m}$. It was assumed that filter efficiency was worst for $0.3 \mu \mathrm{m}$ particles at $70 \%$, and for particles less than $0.1 \mu \mathrm{m}$ removal efficiency was $87 \%$. Although the particle size distribution was defined in terms of only two populations, this range of efficiencies defined average efficiency for particles in each group.

\subsubsection{HEPA Filters}

The HEPA filters were certified for $99.97 \%$ efficiency for removing $0.3 \mu \mathrm{m}$ particles. However, a more conservative efficiency of $99.9 \%$ was assumed for both sets of HEPA filters in series. This more conservative assumption was made to be consistent for multiple filtration steps in series (Burchsted 1979) and to better account for nonidealities such as housing and frame warping, gas sneakage, occasional moisture, etc.

\subsubsection{Carbon Bed for Mercury Adsorption}

The sulfur-impregnated carbon beds were assumed to remove $99 \%$ of the total $\mathrm{Hg}$ still in the offgas at the carbon bed inlet. This efficiency is a rough estimate based on vendor information that suggests higher efficiencies at lower, more optimum temperatures of $158^{\circ} \mathrm{F}$ maximum. Since it was not reasonably possible to operate the carbon beds at such a low temperature, a maximum operating temperature of $200^{\circ} \mathrm{F}$ was assumed, with a more moderate removal efficiency. There is some potential that actual Hg removal efficiencies may not be as high as $99 \%$.

No credit is taken for particulate removal. Sulfur-impregnated carbon designed for the removal of elemental $\mathrm{Hg}$ will have some potential for removing trace organics, but carbon vendors are uncertain about the organic removal efficiencies considering that some of the carbon active sites are occupied by 
sulfur. Organic compounds most likely to be adsorbed on the carbon are those with high molecular weights and vapor pressures. At this time, THC removal is not included in the model.

\subsection{9 $\mathrm{NO}_{\mathrm{x}}$ Specific Catalytic Reactor}

The offgas was reheated to the vendor-specified temperature of $400^{\circ} \mathrm{F}$ before the $\mathrm{NO}_{x} \mathrm{SCR}$ to provide necessary heat for efficient $\mathrm{NO}_{\mathrm{x}}$-ammonia reaction. A stoichiometric quantity of ammonia was added and assumed to achieve $85 \%$ destruction. Ammonia was not allowed in the model to react with any other offgas constituents. The relatively moderate $\mathrm{NO}_{\mathrm{x}}$ destruction efficiency of $85 \%$ was assumed because that level was assumed to be adequate for most mixed waste processes that require $\mathrm{NO}_{\mathrm{x}}$ removal, and to provide confidence that ammonia (ammonia slip) would be limited to $10 \mathrm{ppm}$ in the offgas.

\subsubsection{Offgas Cooling and Condensation}

The offgas was cooled to $100^{\circ} \mathrm{F}$ upstream of the retention tanks to reduce the volumetric flowrate and lower the dewpoint to a temperature nearer to ambient temperature to minimize moisture condensation in the tanks. Significant amounts of moisture were condensed from the offgas in this step. While the reduced offgas volume was desired to minimize volume and costs for the retention tanks, the lowering of the offgas temperature and dewpoint were considered necessary to prevent moisture condensation and corrosion in the tanks. There may be some more optimized or better designed retention tank scenarios that could avoid this cooling step, but it was included for conservativeness in this study.

\subsection{Thermodynamic Chemical Equilibria Calculations}

The capability of ASPEN to predict thermodynamic equilibria at conditions expected in the APCS was demonstrated by comparing results with those predicted using HSC Chemistry for Windows. The comparison showed that similar compounds, concentrations, and phases were predicted by both HSC and ASPEN for identical input conditions.

Calculations were done in each unit operation where phases changed or chemicals reacted to minimize the Gibbs free energy and achieve vapor-liquid-solid equilibrium, and thereby achieve thermodynamic equilibrium. These calculations were done using physical and chemical property data for all specified reactants and products, in all specified phases. Property data for reactants and products used in the calculations included the molecular weight, critical temperature, the standard free energy and enthalpy of formation for the ideal gas and solid at $25^{\circ} \mathrm{C}$, the coefficients for the heat capacity equation for an ideal gas and solid, and the coefficients for the Antoine vapor pressure equation. Complete thermodynamic data for $\mathrm{HgCl}_{2}$ and $\mathrm{SeO}_{2}$ were not in the ASPEN database. The free energy, enthalpy, and heat capacity data for these species was extracted from the HSC Chemistry database and added to the ASPEN database, so these species could be included in ASPEN equilibrium calculations.

Some predicted equilibrium concentrations occasionally appeared inconsistent with measurements from actual systems. Reactions, especially at low temperatures, are often limited by kinetics or mass transfer from reaching thermodynamic equilibrium in the offgas system where residence time is measured in seconds or less. In these cases, the predictions were made to better reflect observed data by limiting the extent of reaction, or by specifying a reaction temperature at which to calculate the equilibrium composition. 
An important example of how thermodymic equilibria was adjusted to better reflect nonideal expectations is the calculation of $\mathrm{Hg}$ speciation in the offgas. At temperatures exceeding $980^{\circ} \mathrm{F}$, elemental $\mathrm{Hg}$ is thermodynamically favored in typical offgas conditions. Hg speciation at the SCC outlet, where the temperature was $2,200^{\circ} \mathrm{F}$, was predicted to be almost entirely elemental $\mathrm{Hg}$. At temperatures below $980^{\circ} \mathrm{F}, \mathrm{HgCl}_{2}$ becomes thermodynamically favored. At temperatures between $800^{\circ} \mathrm{F}$ and $980^{\circ} \mathrm{F}, \mathrm{HgCl}_{2}$ formation from reaction of $\mathrm{Hg}$ and $\mathrm{Cl}$ is rapid and can be described by equilibrium calculations, but the reaction is kinetically limited at lower temperatures (Senior 1997). If the $\mathrm{Hg}-\mathrm{HgCl}_{2}$ reaction were allowed to reach equilibrium in the low temperature wet scrubber, then very little $\mathrm{Hg}$ would exist, and the process simulation would predict that the total $\mathrm{Hg}$ is readily scrubbed in the wet scrubber. However, this is not consistent with empirical data from many sources (Soelberg 1997c). As a result, the minimum equilibrium temperature for the $\mathrm{Hg}-\mathrm{HgCl}_{2}$ reaction in ASPEN calculations was specified at $980^{\circ} \mathrm{F}$. The use of the higher temperature for $\mathrm{Hg}-\mathrm{HgCl}_{2}$ equilibrium calculations considers the rapid temperature quench and effectively "freezes" a significant portion of $\mathrm{Hg}$ as elemental $\mathrm{Hg}$, even in excess $\mathrm{Cl}$ when $\mathrm{HgCl}_{2}$ is thermodynamically favored at quench outlet temperatures.

The solubility of $\mathrm{HgCl}_{2}$ in water and the conversion of $\mathrm{HgCl}_{2}$ to $\mathrm{Hg}_{2} \mathrm{Cl}_{2}(\mathrm{~s})$ in the scrub solution was examined using HSC Chemistry. Approximately $20-30 \%$ of the mercury chlorides can be expected to precipitate out of solution depending on constituent concentrations and the scrub solution temperature. This provides a means for removing mercury from the scrubber solution via filtration or other means, so that the scrub solution can be recycled in the system. However, removal of precipitated $\mathrm{Hg}_{2} \mathrm{Cl}_{2}$ was not considered in this study. In reality, such a practice may be necessary to achieve appreciable $\mathrm{Hg}$ removal in wet scrubber systems that have high recycle:blowdown ratios, so that $\mathrm{Hg}$ is not re-entrained or reevaporated into the offgas.

Equilibrium concentrations of $\mathrm{SO}_{2}$ and $\mathrm{SO}_{3}$ were specified in the partial quench at $1,400^{\circ} \mathrm{F}$ based on kinetic limitations at lower temperatures. Sulfur dioxide was not allowed to react in any subsequent unit operations until entering the free-jet scrubber where $99 \%$ was assumed to react with the sodium hydroxide solution. Also, only $85 \% \mathrm{NO}_{\mathrm{x}}$ removal was assumed in the catalytic reactor.

\subsection{Particle Formation and Revolatilization}

Particulate formation resulting from condensation of volatile metals was expected to occur when the offgas was cooled in the spray quench before the baghouse, the spray quench after the baghouse, and in the acid gas scrubber. The most conservative assumption assumes all particulate formation occurs by homogeneous condensation yielding submicron particulate with particle diameter less than $0.5 \mu \mathrm{m}$. The model also calculated the revolatilization of condensed mercury, arsenic, and selenium compounds when the offgas was reheated after the scrubber and upstream of the $\mathrm{NO}_{x} \mathrm{SCR}$ unit. Some volatilization of trace particulate containing these compounds occurred when the scrubber offgas was heated to $200^{\circ} \mathrm{F}$, and complete volatilization of particulate containing these compounds occurred when the offgas was heated to $400^{\circ} \mathrm{F}$ before the $\mathrm{NO}_{x}$ catalytic reactor. 


\section{APCS PROCESS EVALUATION}

The process simulation computational model was used to evaluate the impacts of process conditions and assumptions on mass and energy balances, system and unit performance, and secondary waste streams to determine if process objectives can reasonably be achieved. Simulation results for the high-flow and low-flow cases are summarized in this section. A detailed description of the simulations is provided in Appendix D.

\subsection{Mass and Energy Balances}

Total and elemental mass balances and energy balances for each unit operation in the APCS were predicted for both high-flow and low-flow cases. Flowsheets for both cases that show stream flowrates, temperatures, and pressures are shown in Figures 6-1 and 6-2.

\subsubsection{Overall Mass Balance}

The calculated mass flowrates input and output APCS streams for both flow cases are summarized in Table 6-1. APCS input and output offgas flowrates for the high-flow case are approximately twice as great as for the low-flow case, primarily because of increased $\mathrm{N}_{2}$. Furthermore, the offgas flowrate in each case roughly doubled as it passed through the APCS. This increase is due to (a) roughly $50 \%$ increase from additional quench water that is evaporated but not subsequently condensed, and (b) roughly $50 \%$ more additional air used in atomizing the scrub solution and to reheat the saturated scrubber outlet offgas.

The total solution discharge from the scrubber system as blowdown was significantly greater in the low-flow system. The higher blowdown in this case was necessary to discharge larger amounts of dissolved salts to allow the scrub solution to stay below $10 \mathrm{wt} \%$ dissolved salts, because considerably more input $\mathrm{HCl}$ was assumed than in the high-flow case. The salt concentration in the scrub solution blowdown for the high-flow case was only $3.8 \mathrm{wt} \%$ and no make-up water was needed.

\subsubsection{Elemental and Particulate Mass Balances}

Elemental and total PM mass flowrates are summarized in Table 6-2. Decontamination factors (DFs) for all metals except mercury were on the order of $10^{9}$. Such high DFs were attributed to the cumulative effects of the baghouse $(D F=100-217)$, the scrubber $(D F=1-340)$, the prefilter $(D F=3.88)$, and double HEPA filters ( $D F=1,000$ for each filter). These $D F$ values for the HEPA filters were comparable to the recommended DF design values of 500 and 1,000 for the first and second HEPA filters to use when considering an accident scenario (Burchsted 1979) when the filters do not perform at the certified efficiency. Thus, the efficiencies for non-Hg elements and total PM in this process simulation are conservative. The decontamination factor for $\mathrm{Hg}$ was on the order of $10^{2}-10^{4}$, depending on the amount of $\mathrm{HgCl}_{2}$ in the offgas that can be removed in the free-jet scrubber.

One of the design features of the R-1 APCS that contributes to such high metals and PM removal effectiveness is the use of multiple control devices in series. The baghouse, prefilter, and HEPA filters are based on filtration of the entire offgas stream and will be effective even in the event of a process upset that could affect the wet scrubber performance, such as a failure of the atomizing air system, the scrub solution nozzles, or scrub solution pumps. The filtration equipment will continue to filter any offgas that 


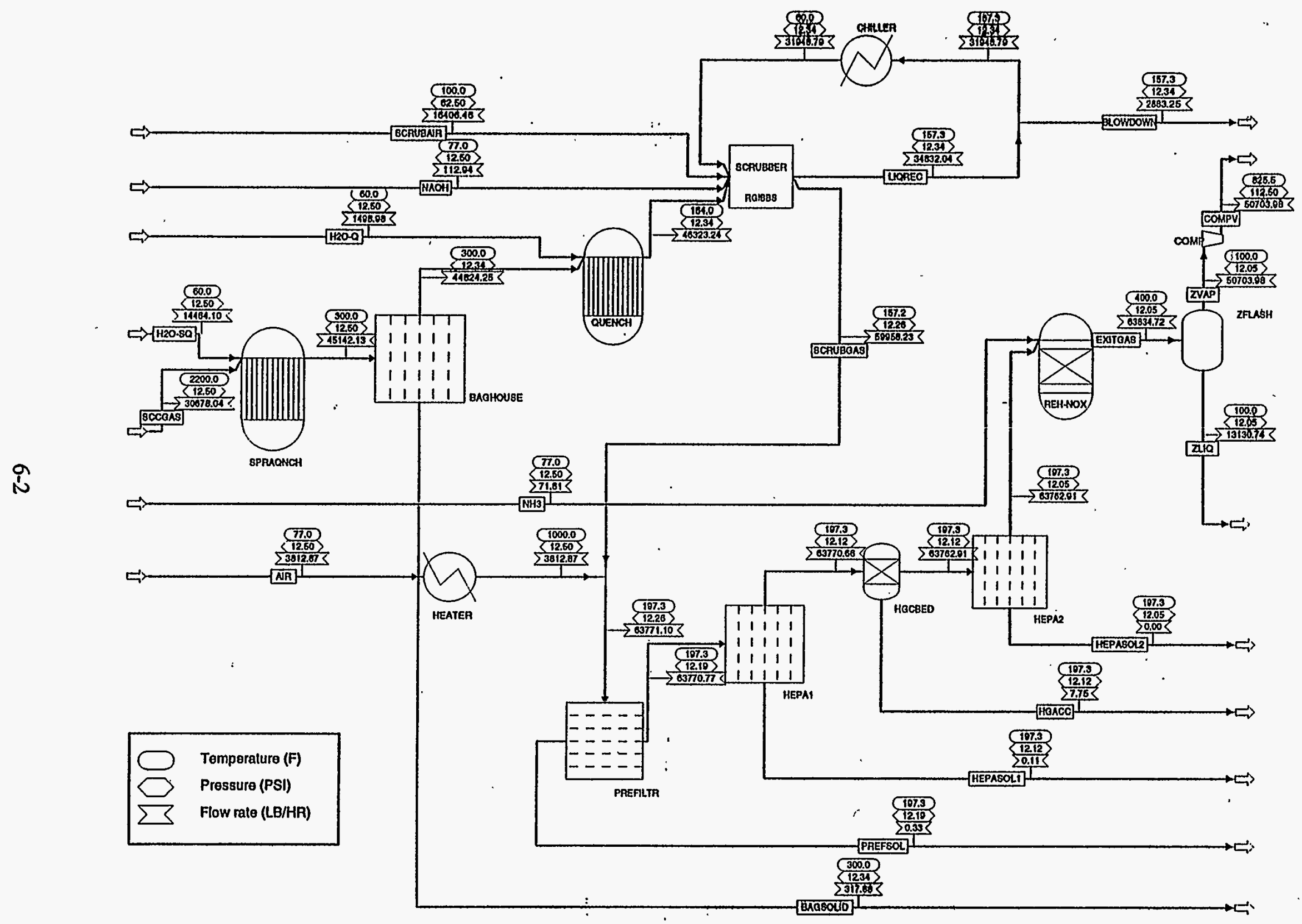

Figure 6-1. APCS process simulation flowsheet for the high-flow case. 


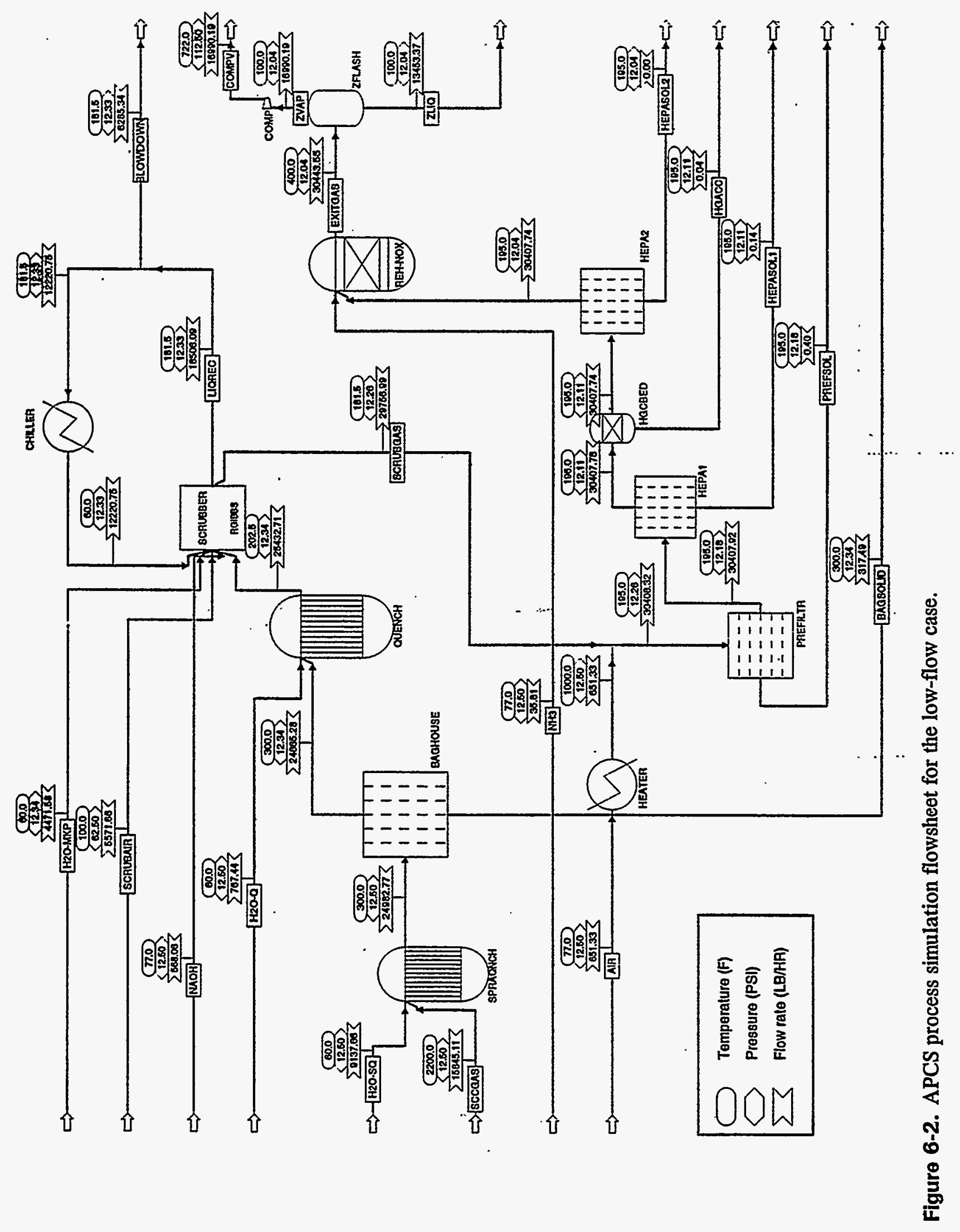


Table 6-1. Mass balance in the APCS of the high-flow and low-flow cases.

\begin{tabular}{|c|c|c|c|}
\hline Stream & Stream Description & $\begin{array}{c}\text { High-flow case } \\
\text { Mass flowrate }(\mathrm{lb} / \mathrm{hr})\end{array}$ & $\begin{array}{c}\text { Low-flow case } \\
\text { Mass flowrate (lb/hr) }\end{array}$ \\
\hline \multicolumn{4}{|l|}{ Feedstreams: } \\
\hline SCCGAS & Thermal treatment offgas & 30,678 & 15,845 \\
\hline $\mathrm{H} 2 \mathrm{O}-\mathrm{SQ}$ & Partial quench water & 14,464 & 9,138 \\
\hline $\mathrm{H} 2 \mathrm{O}-\mathrm{Q}$ & Full quench water & 1,499 & 767 \\
\hline SCRUBAIR & Scrubber atomizing air & 16,406 & 5,569 \\
\hline $\mathrm{NAOH}$ & Sodium hydroxide & 113 & 568 \\
\hline $\mathrm{H} 2 \mathrm{O}-\mathrm{MKP}$ & Make-up water & --- & 4,471 \\
\hline AIR & Air to reheat offgas & 3,813 & 650 \\
\hline \multirow[t]{2}{*}{$\mathrm{NH} 3$} & Ammonia & 72 & 36 \\
\hline & TOTAL: & 67,045 & 37,044 \\
\hline \multicolumn{4}{|c|}{ Product streams: } \\
\hline EXITGAS & Offgas exiting APCS & 63,835 & 30,443 \\
\hline BLOWDOWN & Scrubber blowdown & 2,883 & 6,284 \\
\hline BAGSOLID & Collected baghouse solids & 318 & 317 \\
\hline PREFSOL & Collected prefilter solids & 0.33 & 0.40 \\
\hline HEPASOL1 & Collected HEPA(1) solids & 0.11 & 0.14 \\
\hline HGACC & Captured mercury vapor & 7.75 & 0.042 \\
\hline \multirow[t]{2}{*}{ HEPASOL2 } & Collected HEPA(2) solids & $1.1 \times 10^{-4}$ & $1.3 \times 10^{-4}$ \\
\hline & TOTAL: & 67,044 & 37,045 \\
\hline
\end{tabular}


Table 6-2. Decontamination factors for elemental metals and total PM.

\begin{tabular}{|c|c|c|c|c|c|c|c|c|c|c|}
\hline \multirow[b]{2}{*}{ Element } & \multicolumn{5}{|c|}{ Mass flowrate at outlet of: } & \multicolumn{5}{|c|}{ Decontamination factors: } \\
\hline & SCC & Baghouse & Scrubber & HEPA 1 & HEPA 2 & Baghouse & Scrubber & HEPA 1 & HEPA 2 & Total \\
\hline \multicolumn{11}{|c|}{ High-flow case: } \\
\hline $\mathrm{Ag}$ & 1.08 & $1.08 \mathrm{E}-02$ & $2.48 \mathrm{E}-03$ & $6.39 \mathrm{E}-07$ & $6.39 \mathrm{E}-10$ & 100 & 4.35 & 3,883 & 1,000 & $1.69 \mathrm{E}+09$ \\
\hline As & 4.30 & $4.30 \mathrm{E}-02$ & $9.78 \mathrm{E}-03$ & 2.52E-06 & 2.52E-09 & 100 & 4.40 & 3,883 & 1,000 & $1.71 E+09$ \\
\hline $\mathrm{Ba}$ & 5.37 & 5.37E-02 & $1.23 \mathrm{E}-02$ & $3.18 \mathrm{E}-06$ & 3.18E-09 & 100 & 4.35 & 3,883 & 1,000 & $1.69 \mathrm{E}+09$ \\
\hline $\mathrm{Be}$ & 7.74 & $3.56 \mathrm{E}-02$ & 7.14E-03 & $1.84 \mathrm{E}-06$ & $1.84 \mathrm{E}-09$ & 217 & 4.99 & 3,883 & 1,000 & $4.21 \mathrm{E}+09$ \\
\hline $\mathrm{Cd}$ & 32.25 & $3.22 \mathrm{E}-01$ & $7.41 \mathrm{E}-02$ & 1.91E-05 & 1.91E-08 & 100 & 4.35 & 3,883 & 1,000 & $1.69 E+09$ \\
\hline $\mathrm{Cr}$ & 4.30 & $1.98 \mathrm{E}-02$ & $3.96 \mathrm{E}-03$ & $1.02 \mathrm{E}-06$ & 1.02E-09 & 217 & 4.99 & 3,883 & 1,000 & $4.21 \mathrm{E}+09$ \\
\hline $\mathrm{Hg}$ & 10.74 & 10.74 & 7.82 & 7.82 & 7.82E-02 & 1.00 & 1.37 & 1.00 & 100 & $1.37 E+02$ \\
\hline $\mathrm{Pb}$ & 21.49 & 0.21 & $4.94 \mathrm{E}-02$ & $1.27 \mathrm{E}-05$ & $1.27 \mathrm{E}-08$ & 100 & 4.35 & 3,883 & 1,000 & $1.69 E+09$ \\
\hline $\mathrm{Sb}$ & 3.22 & $3.22 \mathrm{E}-02$ & 7.32E-03 & $1.89 \mathrm{E}-06$ & $1.89 \mathrm{E}-09$ & 100 & 4.40 & 3,883 & 1,000 & $1.71 \mathrm{E}+09$ \\
\hline $\mathrm{Se}$ & 2.15 & $2.15 \mathrm{E}-02$ & $4.88 \mathrm{E}-03$ & $1.26 \mathrm{E}-06$ & $1.26 \mathrm{E}-09$ & 100 & 4.40 & 3,883 & 1,000 & $1.71 E+09$ \\
\hline $\mathrm{Ta}$ & 0.22 & $1.01 \mathrm{E}-03$ & 2.07E-04 & 5.32E-08 & $5.32 \mathrm{E}-11$ & 217 & 4.89 & 3,883 & 1,000 & $4.13 E+09$ \\
\hline All other PM & 186.31 & 0.86 & 0.17 & $4.42 \mathrm{E}-05$ & 4.42E-08 & 217 & 4.99 & 3883.50 & 1,000 & $4.21 E+09$ \\
\hline Total PM & 279.17 & 12.35 & 8.16 & 7.82 & $7.82 \mathrm{e}-02$ & 22.6 & 1.51 & 1.04 & 100 & $3.57 E+03$ \\
\hline \multicolumn{11}{|c|}{ Low-flow case: } \\
\hline $\mathrm{Ag}$ & 1.08 & $1.08 \mathrm{E}-02$ & 2.41E-03 & $6.20 \mathrm{E}-07$ & $6.20 \mathrm{E}-10$ & 100 & 4.47 & 3,883 & 1,000 & $1.74 E+09$ \\
\hline As & 4.30 & 4.29E-02 & $9.60 \mathrm{E}-03$ & 2.47E-06 & $2.47 \mathrm{E}-09$ & 100 & 4.47 & 3,883 & 1,000 & $1.74 \mathrm{E}+09$ \\
\hline $\mathrm{Ba}$ & 5.37 & 5.37E-02 & $1.20 \mathrm{E}-02$ & 3.09E-06 & 3.09E-09 & 100 & 4.47 & 3,883 & 1,000 & $1.74 \mathrm{E}+09$ \\
\hline $\mathrm{Be}$ & 7.74 & $4.95 \mathrm{E}-02$ & $1.04 \mathrm{E}-02$ & 2.67E-06 & 2.67E-09 & 156 & 4.77 & 3,883 & 1,000 & $2.90 \mathrm{E}+09$ \\
\hline $\mathrm{Cd}$ & 32.28 & 3.23E-01 & 7.22E-02 & $1.86 \mathrm{E}-05$ & $1.86 \mathrm{E}-08$ & 100 & 4.47 & 3,883 & 1,000 & $1.74 E+09$ \\
\hline $\mathrm{Cr}$ & 4.30 & $2.75 E-02$ & 5.77E-03 & $1.48 \mathrm{E}-06$ & $1.48 \mathrm{E}-09$ & 156 & 4.77 & 3,883 & 1,000 & $2.90 E+09$ \\
\hline $\mathrm{Hg}$ & 10.74 & 10.74 & $3.16 \mathrm{E}-02$ & $3.16 \mathrm{E}-02$ & $3.16 \mathrm{E}-04$ & 1 & 340 & 1 & 100 & $3.40 \mathrm{E}+04$ \\
\hline $\mathrm{Pb}$ & 21.46 & 0.21 & $4.80 \mathrm{E}-02$ & $\cdot 1.23 \mathrm{E}-05$ & $1.23 \mathrm{E}-08$ & 100 & 4.47 & 3,883 & 1,000 & $1.74 \mathrm{E}+09$ \\
\hline $\mathrm{Sb}$ & 3.22 & 3.22E-02 & $7.20 \mathrm{E}-03$ & $1.85 \mathrm{E}-06$ & 1.85E-09 & 100 & 4.47 & 3,883 & 1,000 & $1.74 \mathrm{E}+09$ \\
\hline $\mathrm{Se}$ & 2.15 & $2.15 \mathrm{E}-02$ & $4.81 E-03$ & $1.24 \mathrm{E}-06$ & 1.24E-09 & 100 & 4.47 & 3,883 & 1,000 & $1.74 E+09$ \\
\hline $\mathrm{Ta}$ & 0.22 & $1.40 \mathrm{E}-03$ & 2.94E-04 & $7.58 \mathrm{E}-08$ & $7.58 \mathrm{E}-11$ & 156 & 4.77 & 3,883 & 1,000 & $2.90 \mathrm{E}+09$ \\
\hline All other PM & 186.31 & 1.19 & $2.50 \mathrm{E}-01$ & $6.43 \mathrm{E}-05$ & $6.43 \mathrm{E}-08$ & 156 & $\because 5$ & 3883 & 1,000 & $2.90 \mathrm{E}+09$ \\
\hline Total PM & 279.16 & 12.70 & 0.45 & $3.17 \mathrm{e}-02$ & $3.16 \mathrm{e}-04$ & 22 & 28 & 14.32 & 100 & $8.84 E+05$ \\
\hline $\begin{array}{l}\text { Notes: 1. Decon } \\
\text { 2. The co } \\
\text { 3. } \mathrm{HCl} \text { is } \\
\text { 4. HEPA } \\
\text { 5. HEPA }\end{array}$ & $\begin{aligned} & \text { mination } F \\
& \text { on bed pre } \\
& \text { moved on } \\
&=\text { Prefilter } \\
&=\text { Carbon b } \\
&\end{aligned}$ & $\begin{array}{l}\text { tor }=\text { inlet elen } \\
\text { des a decontan } \\
\text { by the scrubbe } \\
\text { first bank of } 1 \\
\text { and second ba }\end{array}$ & $\begin{array}{l}\mathrm{DF}=1,000 \text {. } \\
\mathrm{PA} \text { filters. } \\
\text { of HEPA fil }\end{array}$ & $\begin{array}{l}\text { is for merc } \\
\text { is reve }\end{array}$ & $y$ by the ser & 0.100 .1 & the offga & mly in the & system, 1 & $F=6.7$ \\
\hline
\end{tabular}


passes through them as long as the filter media is not physically or thermally damaged or compromised by excessive moisture condensation. The potential of damaging or compromising all four filtration devices in series (baghouse, prefilter, and 2 HEPA filter stages) is remote because the baghouse is preceded by an offgas cooling stage that is separate from the full quench and wet scrubber that precedes the prefilter and HEPAs.

In addition to the four filter stages in series, the wet scrubber is also highly efficient for PM and metals control. Based on vendor information, the PM concentration in the offgas exiting the scrubber depends on the flowrates of the atomizing air and the scrub solution compared to the offgas flowrate, and is relatively independent of the input PM concentration. In its present configuration downstream of the baghouse, the scrubber DFs for PM and metals DFs are very marginal. However, in the event of a failure of the upstream baghouse, the concentrations of the PM and metals at the outlet of the scrubber would not appreciably increase.

The extent of $\mathrm{HCl}$ and $\mathrm{NO}_{x}$ removal was limited to the efficiency of one unit operation within the APCS. Therefore, much smaller (but still highly acceptable) decontamination factors result for these species.

Treated offgas concentrations of metals and PM modeled in this study are compared to expected emission limits in Table 6-3. The calculated metals emissions, excluding mercury, were 4-5 orders of magnitude lower than expected limits. Total PM concentrations range from less than $10 \%$ to less than $0.1 \%$ of the allowable limit. The low treated concentrations for the non-Hg metals and PM provide considerable safety factors for routine process inefficiencies and upsets.

The calculated $\mathrm{Hg}$ concentration exiting the high-flow APCS was over 60 times greater than the limit, while the Hg concentration exiting the low-flow APCS was about $2 / 3$ of the limit. The initial $\mathrm{HCl}$ offgas concentration entering the low-flow APCS was significantly greater (by a factor of 5) than for the high-flow APCS which resulted in the generation of a significant amount of water-soluble $\mathrm{HgCl}_{2}$ that was captured in the wet scrubber. This situation highlights how sensitive $\mathrm{Hg}$ control and emissions can be, even for a high-performance system designed for efficient $\mathrm{Hg}$ control. To meet the $\mathrm{Hg}$ emission limits for the high-flow case, the assumptions of $\mathrm{Hg}$ speciation and control efficiency must be changed, or else the maximum allowable $\mathrm{Hg}$ concentration in the feed must be limited to 2 orders of magnitude less than the feedrate used in the model calculations. This would reduce the maximum $\mathrm{Hg}$ feedrate to approximately $0.1 \mathrm{lb} / \mathrm{hr}$, which corresponds to a relatively low $\mathrm{Hg}$ concentration of $<50 \mathrm{ppm}$ for waste fed to the upstream waste treatment system.

\subsubsection{Energy Balances}

Energy balances were performed to calculate the amount of energy required to (a) cool the recycled scrubber solution, (b) reheat the scrubber outlet (HEPA filter inlet) offgas, (c) heat the offgas at the SCR inlet, and (d) cool the offgas upstream of the retention tanks.

A chiller unit was used to cool the liquid recycle from the scrubber outlet temperature to $60^{\circ} \mathrm{F}$. In the high-flow case where the higher gas flowrate required a $60 \mathrm{gpm}$ scrub solution flowrate, $3.1 \times 10^{6}$ $\mathrm{BTU} / \mathrm{hr}$ was removed by the chiller. In the low-flow case where the scrub solution flowrate was $30 \mathrm{gpm}$, $1.3 \times 10^{6} \mathrm{BTU} / \mathrm{hr}$ was removed. 
Table 6-3. Comparison of estimated emission concentrations to emission limits.

\begin{tabular}{|c|c|c|c|}
\hline Pollutant & High-flow case & Low-flow case & Emission limits ${ }^{a}$ \\
\hline Beryllium & $2 \times 10^{-5} \mathrm{~g} / 24-\mathrm{hrs}$ & $1.6 \times 10^{-5} \mathrm{~g} / 24-\mathrm{hrs}$ & $10 \mathrm{~g} / 24-\mathrm{hrs}$ \\
\hline Mercury $\mu \mathrm{g} / \mathrm{dscm}^{\mathrm{b}}$ & 2,645 & 25 & 40 \\
\hline Total HCl, ppmv $v^{b}$ & 1.4 & 11 & 75 \\
\hline $\begin{array}{l}\text { Total particulate matter, } \\
\mathrm{mg} / \mathrm{dscm}^{\mathrm{b}} \text { (including } \mathrm{PM} \text {, } \\
\text { metals, and } \mathrm{Hg} \text { ) }\end{array}$ & 2.6 & 0.025 & 35 \\
\hline $\operatorname{SVM}^{\mathrm{c}}(\mathrm{Pb}, \mathrm{Cd}), \mu \mathrm{g} / \mathrm{dscm}^{\mathrm{b}}$ & $8 \times 10^{-4}$ & $2 \times 10^{-3}$ & 100 \\
\hline $\begin{array}{l}\operatorname{LVM}^{\mathrm{d}}(\mathrm{As}, \mathrm{Be}, \mathrm{Cr}) \\
\mu \mathrm{g} / \mathrm{dscm}^{\mathrm{b}}\end{array}$ & $2 \times 10^{-4}$ & $5 \times 10^{-4}$ & 55 \\
\hline \multicolumn{4}{|c|}{$\begin{array}{l}\text { a. Strictest of current or proposed emission limits listed in Table } 2-2 \text {. } \\
\text { b. Concentrations are corrected to } 7 \% \text { excess oxygen on a volumetric, dry basis. } \\
\text { c. Semivolatile metals. } \\
\text { d. Low volatile metals. }\end{array}$} \\
\hline
\end{tabular}

The energy requirement to reheat the cooled scrubber offgas was calculated to be $0.91 \times 10^{6}$ $\mathrm{BTU} / \mathrm{hr}$ and $0.16 \times 10^{6} \mathrm{BTU} / \mathrm{hr}$ for the high-flow and low-flow cases, respectively. The reheat energy for the low-flow case was significantly less because of the smaller total gas flow and the smaller temperature increase. The scrubber offgas for the high-flow case was heated $40^{\circ} \mathrm{F}$ from $157^{\circ} \mathrm{F}$ to $197^{\circ} \mathrm{F}$. The scrubber offgas for the low-flow case was only heated $14^{\circ} \mathrm{F}$ from $181^{\circ} \mathrm{F}$ to $195^{\circ} \mathrm{F}$. The offgas temperature could not exceed $200^{\circ} \mathrm{F}$ to prevent degradation of the carbon beds. A reheat temperature that is at least $40^{\circ} \mathrm{F}$ above the gas dewpoint is usually desired to prevent moisture condensation in the filters. Dilution of the offgas with the heated air only decreases its dewpoint temperature by 1 to $2^{\circ} \mathrm{F}$ because of the low volume of added air relative to offgas.

Optimization of the low-flow case to provide more assurance that moisture is not condensed in the HEPÄs, while maintaining a maximum reheated gas temperature of $200^{\circ} \mathrm{F}$, would require additional cooling of the offgas before entering the free-jet scrubber, or else undesirably high air dilution. Additional gas cooling could possibly be achieved by using a chiller or feeding excess water in the second quench. However, this would cause considerable moisture condensation, and would increase capital and operating costs for the APCS. This is an example of issues that are not often well known when waste treatment options such as electrical heating and oxygen combustion are considered to reduce offgas flowrates.

The energy requirements of the reheater upstream of the SCR unit were $3.6 \times 10^{6} \mathrm{BTU} / \mathrm{hr}$ and 1.9 $\times 10^{6} \mathrm{BTU} / \mathrm{hr}$ for the high-flow and low-flow cases, respectively, and were proportional to the total gas flowrate through the process. When the offgas was cooled to a design temperature of $100^{\circ} \mathrm{F}$ upstream of the retention tanks to reduce the required capacity of retention tanks and reduce condensation in the tanks, the total heat removed was $19 \times 10^{6} \mathrm{BTU} / \mathrm{hr}$ and $17 \times 10^{6} \mathrm{BTU} / \mathrm{hr}$ for the high-flow and low-flow cases, respectively. A large quantity of water condensate was generated during this process. In both cases, the water condensate effluent rate was approximately $25 \mathrm{gpm}(12,000 \mathrm{lb} / \mathrm{hr})$. 


\subsubsection{Secondary Waste Streams}

The secondary waste streams include the (a) PM collected in the baghouse, (b) scrub solution discharge containing dissolved salts, salt precipitate, and trace amounts of particulate matter, and (c) prefilters and HEPA filters, (d) spent carbon containing mercury and trace contaminants, and (e) water condensate produced from cooling the offgas upstream of the retention tanks. Excluding the retention tank cooler condensate, the liquid waste from the scrubber represents the largest stream and the greatest challenge in disposal. The largest mass of PM is captured from the baghouse. All other filters collected significantly less particulate matter.

Used baghouse bags are secondary wastes that will be infrequently generated. The frequency for replacement of these materials depends on the operating conditions as well as total particulate and mercury concentrations in the offgas.

The replacement frequency and amounts of filters and carbon adsorbing media are estimated in Tables 6-4 and 6-5. Because of the efficiency of particulate removal upstream of the HEPAs, the replacement frequency of the HEPAs is acceptably low at 800 operating hours for the high-flow case. If the facility is operated continuously 24 hours per day, this equates to once every 33 days. Campaign-type operation of 10 or more $24-\mathrm{hr}$ days each are assumed or used in many scenarios such as the current INEEL WERF incinerator operation. Such a low HEPA filter replacement frequency could provide reasonable assurance that HEPA replacements can be performed when the facility is not operating, barring upset conditions that may rapidly load the filters over a short time.

The HEPA filter replacement frequency for the low-flow case was shorter because only 12 instead of $24 \mathrm{HEPA}$ filters are used in parallel, but the mass flowrate of particulate from the primary treatment unit was assumed to be the same as in the high-flow APCS. Still, the HEPA filter replacement frequency of $340 \mathrm{hrs}$ (14 days) is long enough so that the filters would last through an operating campaign of up to two weeks without a replacement. Also, the total particulate loading in the low-flow case should be considered very conservative. The calculated input total particulate matter concentration in this case was 49,000 $\mathrm{mg} / \mathrm{dscm}$ ( $21 \mathrm{gr} / \mathrm{dscf})$. This concentration is over twice as high as most measurements from incinerators and from arc melter demonstration tests. The level of total particulate was conservatively estimated in Section 3 as about $15 \%$ of the feed mass to the upfront primary treatment unit. This results in a conservatively high total PM concentration in the SCC offgas for both the high-flow and low-flow cases, and relatively large amounts of particulate in the secondary wastes. Actual primary treatment units may produce from 2-10 times less total PM.

The prefilter replacement frequency is more significant at undesirably high frequencies of only 31 and 13 hours for the high-flow and low-flow cases. This model highlights the importance of very efficient upstream PM filtration for satisfactory prefilter and HEPA filter operation. The prefilter replacement frequency could be reduced by using higher efficiency baghouse filters, and by optimizing the prefilter efficiency to match the prefilter and HEPA filter replacement frequency. Prefilter and HEPA filter replacement frequency can also be adjusted by using more prefilters and HEPA filters in a larger matrix, so the gas flow through each filter is smaller and the PM loading rate on each filter is less.

The carbon bed replacement frequency for typical sulfur-impregnated carbon bed adsorbers was determined based on a mercury removal efficiency of $99 \%$. Mercury was considered to be the limiting element and loading of trace organics was not included in the calculations of carbon bed capacity. The total mass of carbon was calculated using the $\mathrm{Hg}$ mass flowrate in the offgas, $\mathrm{Hg}$ loading capacity of the 
Table 6-4. Masses and volumes of secondary wastes generated (high-flow case).

\begin{tabular}{|c|c|c|c|}
\hline Secondary waste & $\begin{array}{l}\text { Replacement frequency } \\
\text { (operating hours) }\end{array}$ & $\begin{array}{l}\text { Mass rate } \\
(\mathrm{lb} / \mathrm{hr})(\mathrm{a})\end{array}$ & $\begin{array}{c}\text { Volume rate } \\
\left(\mathrm{ft}^{3} / \mathrm{hr}\right)\end{array}$ \\
\hline Baghouse bags & $4,000(b)$ & 0.465 & 24 \\
\hline Prefilters & $31(c)$ & NK & NK \\
\hline HEPA filters (front 24 filters) & 800 (d) & $0.12(\mathrm{e})$ & $5 \times 10^{-3}$ \\
\hline HEPA filters (back 24 filters) & 4,000 (f) & $0.025(\mathrm{e})$ & $1 \times 10^{-3}$ \\
\hline Carbon media & $1,820(\mathrm{~g})$ & 46.5 & 1.3 \\
\hline \multicolumn{4}{|c|}{$\begin{array}{l}\text { NK = Not known } \\
\text { a. Including mass of contaminants (dust and Hg). } \\
\text { b. It is assumed that each bag will require replacement every } 4,000 \text { operating hours. } \\
\text { c. Prefilters are assumed to load up to } 0.44 \mathrm{lb} \text { of dust before replacement (Burchsted 1979). } \\
\text { d. HEPA filters are assumed to load up to } 4 \mathrm{lb} \text { of dust before replacement (Burchsted 1979). } \\
\text { e. Assumed weight of dirty HEPA filter to be } 99 \mathrm{lb} \text { (Burchsted } 1979) \text {. } \\
\text { f. The calculated frequency is very low based on a loading of } 4 \mathrm{lb} \text { dust (Burchsted 1979), so it is simply assumed that } \\
\text { replacement will occur once every } 4,000 \text { operating hours (roughly once per year of operation, if the entire facility is operated } \\
\text { about } 4,000 \text { hours per year). } \\
\text { g. Adsorptive capacity of carbon assumed to be } 0.2 \mathrm{lb} \mathrm{Hg} / \mathrm{lb} \mathrm{C} \text {. } \\
\text { h. Assumes volume of Hg-contaminated carbon media is equal to volume of new carbon media. Carbon density of } 30 \mathrm{lb} / \mathrm{ft}^{3} \text {. }\end{array}$} \\
\hline
\end{tabular}

Table 6-5. Masses and volumes of secondary wastes generated (low-flow case).

\begin{tabular}{|c|c|c|c|}
\hline Secondary waste & $\begin{array}{l}\text { Replacement frequency } \\
\text { (operating hours) }\end{array}$ & $\begin{array}{l}\text { Mass rate } \\
(\mathrm{lb} / \mathrm{hr})(\mathrm{a})\end{array}$ & $\begin{array}{l}\text { Volume rate } \\
\left(\mathrm{ft}^{3} / \mathrm{hr}\right)\end{array}$ \\
\hline Baghouse bags & 4,000 (b) & 0.27 & 14 \\
\hline Prefilters & $13(c)$ & NK & NK \\
\hline HEPA filters (front 12 filters) & 340 (d) & $0.29(\mathrm{e})$ & $1.2 \times 10^{-2}$ \\
\hline HEPA filters (back 12 filters)) & $4,000(f)$ & $0.025(\mathrm{e})$ & $1 \times 10^{-3}$ \\
\hline Carbon media & $167,700(\mathrm{~g})$ & 0.25 & 0.08 \\
\hline \multicolumn{4}{|c|}{ 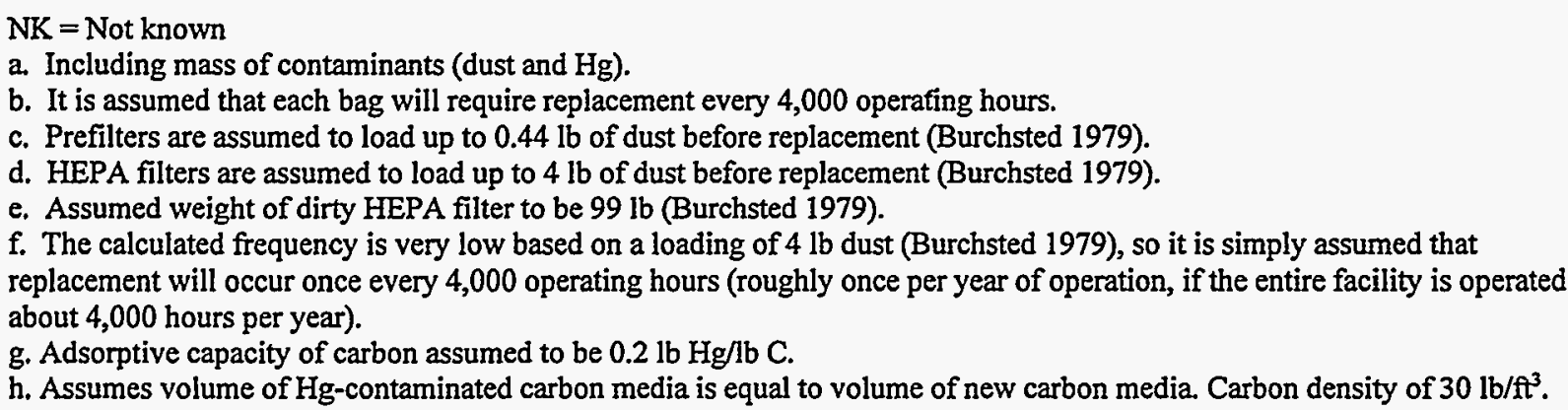 } \\
\hline
\end{tabular}


carbon adsorbers, and the density of the carbon granules (Appendix C). Calculations showed that 81,000

$\mathrm{lb}$ of carbon media would last for approximately 1,800 hours for the high-flow case with the high $\mathrm{Hg}$ mass flowrate in the offgas entering the carbon bed. In the low-flow case, more of the total $\mathrm{Hg}$ was removed in the wet scrubber. This extended the lifetime of the sulfur-impregnated carbon, so that $40,500 \mathrm{lb}$ of carbon would last nearly 168,000 operating hours.

\subsection{APCS Equipment Evaluations}

Results and discussion of the process simulation with respect to specific APCS equipment is discussed in the following sections.

\subsubsection{Partial and Total Quench Towers}

The purpose of the first partial quench tower using water spray evaporation is to rapidly cool the $\mathrm{SCC}$ offgas from $2,200^{\circ} \mathrm{F}$ to $300^{\circ} \mathrm{F}$ to reduce $\mathrm{D} / \mathrm{F}$ formation and to protect baghouse material from excessively high temperatures. The effect of varying the SCC outlet temperature on process operation and APCS performance has not been evaluated in this study. An SCC temperature of $2,200^{\circ} \mathrm{F}$ is only required if the system is designed to treat PCB-contaminated wastes. If a lower SCC temperature such as $1,800^{\circ} \mathrm{F}$ is used, then less water evaporation is needed to cool the offgas. Also, the offgas dewpoint (and temperature) following the full quench will be lower. This would enable a wider reheat temperature difference, reduce the volumetric offgas flowrate, reduce energy requirements, reduce moisture condensation and potential corrosion problems, and improve sulfur-impregnated carbon bed performance.

The water fed into each quench unit was assumed to be utility water available at $60^{\circ} \mathrm{F}$. Recycling scrubber solution blowdown to the quench towers was not investigated in this study. Recycle of these wastewater streams as means of reducing the total secondary waste stream should be investigated. However, if the scrubber solution blowdown is not treated to remove dissolved and suspended solids (especially $\mathrm{Hg}$ species) then these contaminants can be re-entrained as very small (submicron) particles when the water droplets evaporate. These small particles are especially difficult to capture in the scrubber. The greatest potential for untreated scrub solution recycle is to inject it into the partial quench tower, where much of the small particles formed from evaporation can be captured in the baghouse.

\subsubsection{Baghouse}

Variations in the particle size distribution of offgas particulate investigated in this study had almost no effect on the removal of particulate by the baghouse. Given the conservative assumption of $99 \%$ removal for $<0.5 \mu \mathrm{m}$ PM and $99.9 \%$ removal for $>0.5 \mu \mathrm{m}$ PM, the particulate mass removed in the baghouse was nearly identical for the two cases. The presence of the baghouse upstream of the wet scrubber is a viable feature for improving the performance of the entire offgas system, since problems associated with particulate in the scrub solution such as sludge deposition, nozzle erosion, and particle reentrainment loading are significantly reduced.

\subsubsection{Wet Scrubber}

The atomization of the liquid within the free-jet scrubber creates submicron droplets with high surface area, upon which particulate matter can accumulate. The resulting total available liquid surface area is generally so great that the outlet particulate concentration approaches a limiting value and is practically independent of the particulate load in the gas entering the scrubber. Only about $2 \mathrm{lb} / \mathrm{hr}$ 
particulate is removed in the scrubber, because the baghouse removes over $99 \%$ of the total PM. Most of the difference in particulate size distribution attributed to feed composition is eliminated at the scrubber where the outlet particulate concentration in the scrubber offgas is a function of the atomizing air fed into the scrubber.

It was assumed that $99.9 \%$ of the oxidized mercury, in the form of $\mathrm{HgCl}_{2}$, is removed in the wet scrubber. Approximately $20-30 \%$ of the mercury chlorides can be expected to precipitate out of solution depending on constituent concentrations and scrubber solution temperature. This provides a means for removing mercury from the scrubber blowdown via filtration or other separation methods, while still potentially recycling the blowdown liquid elsewhere in the process such as in the partial quench process upstream of the baghouse. Treatment and handling of scrubber solution was not included in this study.

\subsubsection{Offgas Reheat}

The fully quenched offgas dewpoint is a critical design and operating parameter for all wet systems that include offgas reheating, HEPA filtration, and carbon bed adsorption. This is because offgas reheating should be great enough to raise the gas temperature at least $40^{\circ} \mathrm{F}$ above the dewpoint but not exceed maximum operating temperatures for downstream equipment such as the sulfur-impregnated carbon beds. A feature of the R-1 APCS modeled in this study that helps to address this situation is the "heated air" reheater. This method of offgas reheating lowers the dewpoint through the addition of dry hot air, although the decrease in dewpoint temperature is only $1-2^{\circ} \mathrm{F}$ in the current models because of the low reheat air flowrate relative to the offgas flowrate.

\subsubsection{Offgas Retention Tanks}

The volume of offgas holding tanks was calculated based on anticipated operating conditions. The tanks were designed to hold the treated offgas until it can be analyzed and determined to be sufficiently clean to be released into the environment. The total hold time before tank evacuation is initiated was defined by the total time required to collect and analyze gas samples from the tank and report the results. After determining that the tank contents can be released, the gas is released. The time required to fill a tank should exceed the time required to collect and analyze tank gas samples and to evacuate the tank contents.

Several design specifications were assumed. The offgas was cooled to reduce the moisture content, lower the gas volumetric flowrate, and reduce the required storage volume. In addition, the tanks were designed to hold $10 \%$ more than expected in this worst case. Total tank fill time was assumed to be two hours greater than the total hold and evacuation time. Total sample collection, analysis, and reporting time is assumed to be 12 hours. Only $70 \%$ of tank contents are removed during a given evacuation period.

If the gas in the holding tanks cannot be released directly into the environment, it must be recycled through the treatment system and subsequently the offgas treatment system to remove the undesirable constituents. To stay within the gas-carrying capacity of the total system, waste feeding may have to be reduced or stopped until the tank contents have been recycled. During tank evacuation, only $70 \%$ of the tank contents can be expected to be removed. Thus, the remaining tank contents may contaminate the next batch of gas, requiring additional gas recycle. 


\section{EQUIPMENT SIZE AND COST ESTIMATES}

The installed capital costs for the offgas systems for the high-flow and low-flow cases were estimated using vendor-provided purchase costs, equipment and system and footprint estimates, and installation cost factors. The estimated costs are expected to be representative but not exact, since many design and operating details were not included at this point, and cannot be included without a more specific treatment system scenario. Facility capital costs such as building, design, inspection, electrical, instrumentation, and management cost factors are generally consistent with those used in cost estimates for the ITTS study (Feizollahi 1996).

The capital cost estimates of the APCS alternatives for the high-flow and low-flow cases are shown in Table 7-1. The estimates are organized to separately show the major cost components, which are the (a) purchase costs of major equipment, (b) other equipment and installation costs, (c) building costs, (d) indirect costs, and (e) other facility capital costs. The costs of installation and other equipment and indirect costs are determined using cost factors. Consistent with most DOE facilities total capital cost estimates, the actual major equipment purchase cost is the smallest of all these cost components.

The largest single cost component is the "other facility capital costs" category. This cost category includes five key subcomponents, namely design, inspection, project management, and construction management. The design subcomponent includes both Title 1 (preliminary design) and Title 2 (detailed design) and is estimated at $25 \%$ of the facility construction cost for an alpha facility. The inspection subcomponent includes Title 3, or engineering support during construction, and is estimated at $7 \%$ of the facility construction cost. The project management subcomponent is estimated at $10 \%$ of the facility construction cost and includes project management costs incurred both by DOE and the site management and operations (M\&O) contractor. Construction management (CM) is estimated at $17 \%$ of the construction costs, which is the sum of the equipment, building, and indirect costs. Construction management includes material and services procurement and control activities, which are typically handled by the site $\mathrm{CM}$ contractor. Allowances for project scope change or management reserve is estimated at $10 \%$ of construction costs.

Facility construction costs include the rest of the installed costs and include the purchase cost of equipment, installation costs, building costs, and indirect costs as defined below:

- Major equipment purchase cost. Cost estimates for the individual pieces of equipment that comprise the air pollution control system were primarily determined by soliciting budgetary costs from suppliers and vendors. Where this was not a practical option, engineering estimation methods were used and costs were scaled for time and capacity.

- Other equipment and installation costs. For systems which involve processing equipment, the allowance for electrical is $15 \%$, mechanical support is $30 \%$, and instrumentation is $30 \%$ of the equipment costs. Factors for installation costs and costs for connecting ductwork were also included in the equipment subtotal at $30 \%$ and $10 \%$ of the purchase cost, respectively.

- Building and structures. Building and structure costs are estimated by multiplying building unit costs by the space square footage allocated to each process unit. Assumed unit rates are applied to several categories of buildings. The category chosen for this study was that of an alpha waste processing area rated at $\$ 1,700$ per square foot for triple-confinement alpha cells. Building unit 
Table 7-1. Capital costs $(\$ 1,000)$ for conceptual APCS alternatives.

\begin{tabular}{|c|c|c|}
\hline Case: & 1 & 2 \\
\hline \multicolumn{3}{|l|}{ Major equipment purchase cost: } \\
\hline Partial quench spray tower & 251 & 186 \\
\hline Baghouse (2) (one in operation, one as backup) & 324 & 182 \\
\hline Full quench spray tower & 44 & 32 \\
\hline Free-jet scrubber & 160 & 117 \\
\hline Scrubber water chiller & 125 & 90 \\
\hline Air heater & 30 & 30 \\
\hline 2-HEPA filtration systems (includes prefilters) (one in operation, one as backup) & 377 & 189 \\
\hline Carbon adsorbers & 1,404 & 520 \\
\hline Reheater & 196 & 196 \\
\hline $\mathrm{NO}_{x}$ control & 500 & 400 \\
\hline \multicolumn{3}{|l|}{ Retention tanks (3) Nacuum pumps (2) } \\
\hline CEMs & Pressure vessels (3)/Compressors (2) & 166 \\
\hline Subtotal of major equipment purchase costs & 3,577 & 2,108 \\
\hline \multicolumn{3}{|l|}{ Other equipment and installation costs: } \\
\hline Electrical, $15 \%$ of equipment cost & 537 & 316 \\
\hline Mechanical support, $30 \%$ of equipment cost & 1,073 & 632 \\
\hline Instrumentation, $30 \%$ of equipment cost & 1,073 & 632 \\
\hline Installation costs, $30 \%$ of purchase cost & 1,073 & 632 \\
\hline Connecting ductwork, $10 \%$ of purchase cost & 358 & 211 \\
\hline Subtotal of other equipment and installation costs: & 4,114 & 2,424 \\
\hline \multicolumn{3}{|l|}{ Building cost (at $\$ 1,700 / f t^{2}$ for alpha containment): } \\
\hline Area of building housing APCS, $\mathrm{ft}^{2}$ & 5,400 & 3,090 \\
\hline \multicolumn{3}{|l|}{ APCS building cost, $\$ 1,700 / \mathrm{ft}^{2}$ for alpha containment } \\
\hline \multicolumn{3}{|l|}{ Area of building housing retention tanks or pressure vessels, $\mathrm{ft}^{2}$} \\
\hline \multicolumn{3}{|l|}{ Retention tanks/pressure vessel building cost, $\$ 420 / t^{2}$ for packaged waste handling areas } \\
\hline Building cost: & 9,180 & 5,253 \\
\hline Subtotal of installed equipment and building: & 16,871 & 9,785 \\
\hline Indirect costs, $29 \%$ of total of building, structure, and equipment costs & 4,892 & 2,838 \\
\hline Total facility construction costs: & 21,763 & 12,62 \\
\hline \multicolumn{3}{|l|}{ Other facility capital costs: } \\
\hline Design, $25 \%$ of facility construction costs & 5,441 & 3,156 \\
\hline Inspection, $7 \%$ of facility construction costs & 1,523 & 884 \\
\hline Project management, $10 \%$ of facility construction costs & 2,176 & 1,262 \\
\hline Construction management, $17 \%$ of construction costs & 3,700 & 2,146 \\
\hline Allowance for proj. scope change or mgmt reserve, $10 \%$ of const. costs & 2,176 & 1,262 \\
\hline Subtotal of other facility capital costs: & 15,017 & 8,710 \\
\hline Subtotal of installed facility capital costs: & 36,780 & 21,33 \\
\hline Contingency, $25 \%$ of total installed capital costs & 9,195 & 5,333 \\
\hline Total installed capital cost: & 45,975 & \\
\hline
\end{tabular}

Notes:

Case 1: High-flow case with the baseline APCS.

Case 4: Low-flow case with baseline APCS using tanks and vacuum pumps.

Case 7: High-flow case with baseline APCS excluding NOx control system.

Case 2: Low-flow case with the baseline APCS.

Case 5: High-flow case with baseline APCS using

Case 10: Low-flow case with baseline APCS excluding carbon adsorption.

Case 8: Low-flow case with baseline APCS excluc 


\begin{tabular}{|c|c|c|c|c|c|c|c|}
\hline 3 & 4 & 5 & 6 & 7 & 8 & 9 & 10 \\
\hline 251 & 186 & 251 & 186 & 251 & 186 & 251 & 186 \\
\hline 337 & 189 & 337 & 189 & 337 & 189 & 337 & 189 \\
\hline 44 & 32 & 44 & 32 & 44 & 32 & 44 & 32 \\
\hline 160 & 117 & 160 & 117 & 160 & 117 & 160 & 117 \\
\hline 125 & 90 & 125 & 90 & 125 & 90 & 125 & 90 \\
\hline 30 & 30 & 30 & 30 & 30 & 30 & 30 & 30 \\
\hline 377 & 189 & 377 & 189 & 377 & 189 & 189 & 94 \\
\hline 1,404 & 520 & 1,404 & 520 & 1,404 & 520 & & \\
\hline 196 & 196 & 196 & 196 & 196 & 196 & 196 & 196 \\
\hline 500 & 400 & 500 & 400 & & & 500 & 400 \\
\hline \multirow[t]{2}{*}{62,100} & 31,500 & & & & & & \\
\hline & & 26,225 & 10,775 & & & & \\
\hline 166 & 166 & 166 & 166 & 166 & 166 & 166 & 166 \\
\hline 65,690 & 33,615 & 29,815 & 12,890 & 3,090 & 1,715 & 1,998 & 1,500 \\
\hline 9,853 & 5,042 & 4,472 & 1,933 & 463 & 257 & 300 & 225 \\
\hline 19,707 & 10,084 & 8,944 & 3,867 & 927 & 514 & 599 & 450 \\
\hline 19,707 & 10,084 & 8,944 & 3,867 & 927 & 514 & 599 & 450 \\
\hline 19,707 & 10,084 & 8,944 & 3,867 & 927 & 514 & 599 & 450 \\
\hline 6,569 & 3,361 & 2,981 & 1,289 & 309 & 171 & 200 & 150 \\
\hline 75,543 & 38,657 & 34,287 & 14,823 & 3,553 & 1,972 & 2,297 & 1,725 \\
\hline 5,400 & 3,090 & 5,400 & 3,090 & 5,400 & 3,090 & 5,400 & 3,090 \\
\hline 9,180 & 5,253 & 9,180 & 5,253 & & & & \\
\hline 367,500 & 187,500 & 152,000 & 67,500 & & & & \\
\hline 154,350 & 78,750 & 63,840 & 28,350 & & & & \\
\hline 163,530 & 84,003 & 73,020 & 33,603 & 9,180 & 5,253 & 9,180 & 5,253 \\
\hline 304,763 & 156,275 & 137,122 & 61,316 & 15,823 & 8,940 & 13,475 & 8,479 \\
\hline 88,381 & 45,320 & 39,765 & 17,782 & 4,589 & 2,593 & 3,908 & 2,459 \\
\hline 393,144 & 201,595 & 176,887 & 79,098 & 20,412 & 11,533 & 17,383 & 10,938 \\
\hline 98,286 & 50,399 & 44,222 & 19,775 & 5,103 & 2,883 & 4,346 & 2,734 \\
\hline 27,520 & 14,112 & 12,382 & 5,537 & 1,429 & 807 & 1,217 & 766 \\
\hline 39,314 & 20,159 & 17,689 & 7,910 & 2,041 & 1,153 & 1,738 & 1,094 \\
\hline 66,835 & 34,271 & 30,071 & 13,447 & 3,470 & 1,961 & 2,955 & 1,859 \\
\hline 39,314 & 20,159 & 17,689 & 7,910 & 2,041 & 1,153 & 1,738 & 1,094 \\
\hline 271,270 & 139,101 & 122,052 & 54,578 & 14,084 & 7,958 & 11,994 & 7,547 \\
\hline 664,414 & 340,695 & 298,939 & 133,676 & 34,496 & 19,490 & 29,377 & 18,485 \\
\hline 166,104 & 85,174 & 74,735 & 33,419 & 8,624 & 4,873 & 7,344 & 4,621 \\
\hline 830,518 & 425,869 & 373,674 & 167,095 & 43,120 & 24,363 & 36,721 & 23,106 \\
\hline
\end{tabular}

essure vessels/compressors. $\mathrm{g} \mathrm{NO}_{\mathrm{x}}$ control system.
Case 3: High-flow case with baseline APCs using retention tanks and vacuum pumps.

Case 6: Low-flow case with baseline APCS using pressure vessels and compressors.

Case 9: High-flow case with baseline APCS excluding any form of carbon adsorption. 
rates incorporate all material and labor needed for constructing the building shell including utilities, lighting, heating, ventilation, and air conditioning (HVAC), and site development costs.

- Indirect costs. Indirect costs, including subcontractor overhead and fee, are estimated at $29 \%$ of the total of equipment, building, and structure costs.

Because the costs are a planning-level estimate, a $25 \%$ contingency is also included. The contingency is applied to the total of all components in the production facility construction cost.

\subsection{Equipment Sizing}

The major components of the air pollution control system contributing to the size of the housing required to contain the system were the baghouse, the spray quench towers, the HEPA filters, and the carbon adsorbers. All of the other process units were considered to be small factors in determining the total equipment footprint needed to estimate a building size in square feet. The footprint for the baghouse for the high-flow case was calculated in ASPEN to be roughly $900 \mathrm{ft}^{2}$. The baghouse footprint for the lowflow case was determined to be about $500 \mathrm{ft}^{2}$.

The estimated footprint for the Flanders HEPA filter system, including prefilters and two banks of HEPAs, was $320 \mathrm{ft}^{2}$ for the high-flow case and $160 \mathrm{ft}^{2}$ for the low-flow case. The carbon adsorption system using fixed beds in parallel was sized based on vendor information. For the high-flow case, calculations showed that six beds would be required in parallel to handle the gas flowrate with each bed being $10 \mathrm{ft}$ in diameter and $15 \mathrm{ft}$ long, a footprint of $150 \mathrm{ft}^{2}$ per bed and a total footprint of $900 \mathrm{ft}^{2}$. The low-flow case only required three parallel beds of the same size for a total footprint of $450 \mathrm{ft}^{2}$.

The partial spray quench tower was $100 \mathrm{ft}^{2}$ for the high-flow case and $50 \mathrm{ft}^{2}$ for the low-flow case. The estimated footprint for the full quench tower was $30 \mathrm{ft}^{2}$ for the high-flow case and $25 \mathrm{ft}^{2}$ for the lowflow case.

The total footprint for the other pieces of equipment were assumed to occupy roughly $450 \mathrm{ft}^{2}$ for the high-flow case and $360 \mathrm{ft}^{2}$ for the low-flow case. This area includes the SCR at $150 \mathrm{ft}^{2}$; free-jet scrubber at $100 \mathrm{ft}^{2}$ for high-flow and $60 \mathrm{ft}^{2}$ for low-flow; scrubber water chiller at $100 \mathrm{ft}^{2}$ for high-flow and $50 \mathrm{ft}^{2}$ for low-flow; and heater and reheater at $100 \mathrm{ft}^{2}$ together.

The total equipment footprint was multiplied by a factor of two, to account for such space as the areas needed between each major equipment component, access around the equipment, and filter and adsorbent replacement space. Consideration was not given to how some equipment items may be physically located on decks or structures above other equipment, which may in fact be desirable not only to reduce footprint but also to avoid long or tortuous runs of interconnecting ducting. Costs for non-alpha containment building space for control rooms, storage, laboratories, maintenance, and other activities are also not specifically itemized, but should be considered to be within the factor of two safety factor for the alpha-containment space. The total area of the alpha-containment building for the APCS is estimated at $5,400 \mathrm{ft}^{2}$ for the high-flow case and $3,090 \mathrm{ft}^{2}$ for the low-flow case. 


\subsection{Capital Cost Estimate}

The purchase costs for major pieces of equipment were based on data supplied by vendors. These costs are itemized below for each major component in the offgas systems:

Item

Partial quench tower

Baghouse

Full quench tower

Free-jet Scrubber

Scrubber water chiller

Air heater

Prefilter/HEPA filters

Fixed bed carbon adsorbers

Reheater

$\mathrm{SCR}$ for $\mathrm{NO}_{x}$ Control

Retention tanks (3)

Vacuum pump ( 1 and 1 backup)

Pressure vessels (3)

Compressors (1 and 1 backup)

CEMS

$\mathrm{O}_{2}$ monitors (1 paramagnetic, 1 fuel cell): $\$ 7,000$

$\mathrm{CO}_{2}$ monitor: $\$ 5,000$

$\mathrm{CO}$ monitor: $\$ 6,000$

$\mathrm{NO}_{\mathrm{x}}$ monitor (2): $\$ 20,000$

THC monitor: $\$ 12,000$

Gas conditioner and pump: $\$ 20,000$

DAS: $\$ 10,000$

Heated sample line: $\$ 20,000$

Flow splitter: $\$ 10,000$

Stripchart recorder: $\$ 5,000$

Regulators, fittings, etc.: $\$ 5,000$

Instrument racks: $\$ 5,000$

Offgas flowmeter: $\$ 1,000$

Pressure transducer: $\$ 2,000$

In-situ particulate matter monitor: $\$ 25,000$

Misc. fittings, valves, tubing, gauges: $\$ 13,000$
High-flow case

251,000

Low-flow case

168,000

44,000

160,000

125,000

30,000

189,000

$1,404,000$

196,000

500,000

$60,000,000$

$2,100,000$

$23,000,000$

$2,800,000$

166,000
186,000

94,000

32,000

117,000

90,000

30,000

94,000

520,000

196,000

400,000

$30,000,000$

$1,500,000$

$10,000,000$

850,000

166,000 
Figure 7-1 shows how each major component contributed to the total purchased equipment cost. The carbon adsorber beds, $\mathrm{NO}_{x}$ control unit, and HEPA filtration system are the largest contributors to the purchased equipment cost. For the carbon beds, the high-flow case was calculated to need 6 beds in parallel that are $10 \mathrm{ft}$ in diameter, $15 \mathrm{ft}$ long, with a carbon bed depth of $3 \mathrm{ft}$. The ASPEN model assumed the carbon beds had a removal efficiency of $99 \%$. Thus, it was calculated that there would be $7.75 \mathrm{lb}$ of mercury captured in the beds per hour. At this capture rate and an assumed carbon adsorptive capacity of $20 \mathrm{wt} \%$, the carbon beds were calculated to have a lifetime of 1,800 hours of operation before saturation. The cost of the carbon needed to achieve this removal would be on the order of $\$ 404,000$. This cost is rather high because of the need to use sulfur-impregnated carbon because of the expected high percentage of elemental mercury as opposed to oxidized species of mercury. It was assumed that $99.6 \%$ of the mercury going to the carbon beds was elemental. The cost of impregnated carbon is about $\$ 5 / \mathrm{lb}$ compared to plain activated carbon which costs between $\$ 0.50-\$ 1 / \mathrm{lb}$.

The low-flow case, at half the offgas flowrate of the high-flow case, only needed 3 beds of carbon of the same dimensions stated previously. The same assumptions of removal efficiency and adsorptive capacity were made as in the high-flow case. For this case only $0.042 \mathrm{lb}$ of mercury would be captured in the carbon beds per hour. At this capture rate, the carbon beds would have a lifetime of 168,000 hours of operation. Assuming 4,032 hrs per year as in the life-cycle costs, the carbon beds would have a lifetime of 42 operational years. The cost of the carbon to achieve this removal would be about $\$ 20,000$. This cost is much lower than that of the high-flow case because much of the $\mathrm{Hg}$ was removed in the low-flow case in the scrubber upstream of the carbon beds and because the mercury was assumed to be $100 \% \mathrm{HgCl}_{2}$ because of the high $\mathrm{HCl}$ levels. Therefore, plain activated carbon can be used instead of impregnated carbons at a cost of about $\$ 0.50 / 1 b$.

The estimated installed APCS total capital cost for the high-flow case was about $\$ 46$ million, and the installed APCS cost for the low-flow case was about \$27 million. These costs do not include the cost for three retention tanks and associated equipment that would be used to retain the offgas exiting the SCR $\mathrm{NO}_{x}$ control process until analysis could be completed to show that the offgas meets regulatory limits.

Figure 7-2 shows the components of the total capital cost for the two systems modeled in this study. The largest cost component is the "facility capital costs" which includes design, inspection, project management, construction management, and an allowance for project scope change or management reserve. Contingency and building costs are similar in magnitude and are the second and third largest cost components. The remaining three factors, indirect costs, equipment installation costs, and equipment purchase costs, are also roughly equivalent, although the actual purchase cost of major equipment is the smallest of all cost components.

\subsection{Capital Cost Sensitivity Studies}

A number of cost variations were evaluated for the baseline system. These variations were:

- Inclusion of evacuated retention tanks and associated equipment

- Inclusion of pressurized retention tanks and associated equipment

- Deletion of the SCR for $\mathrm{NO}_{x}$ control

- Deletion of the carbon beds for $\mathrm{Hg}$ control. 

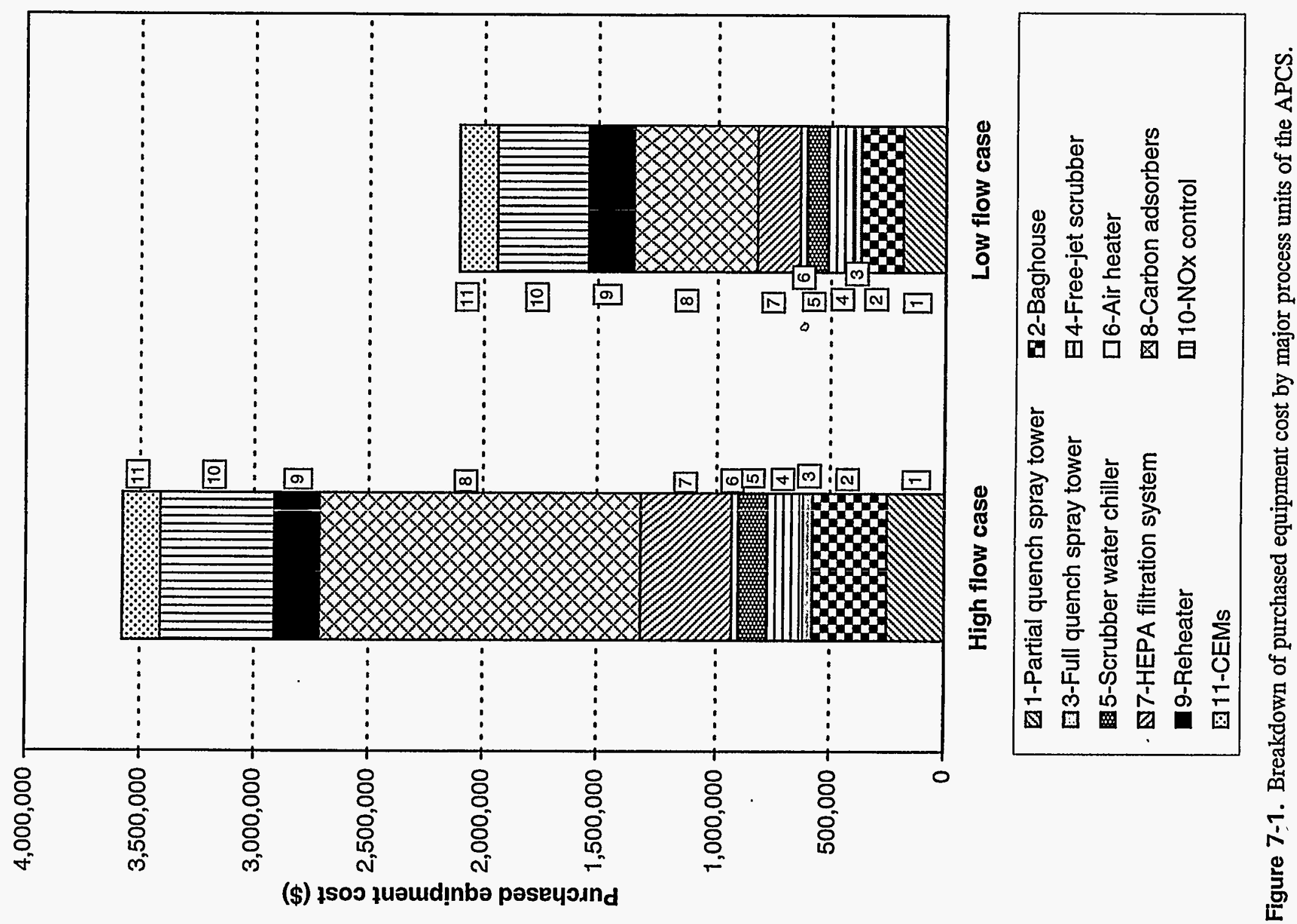


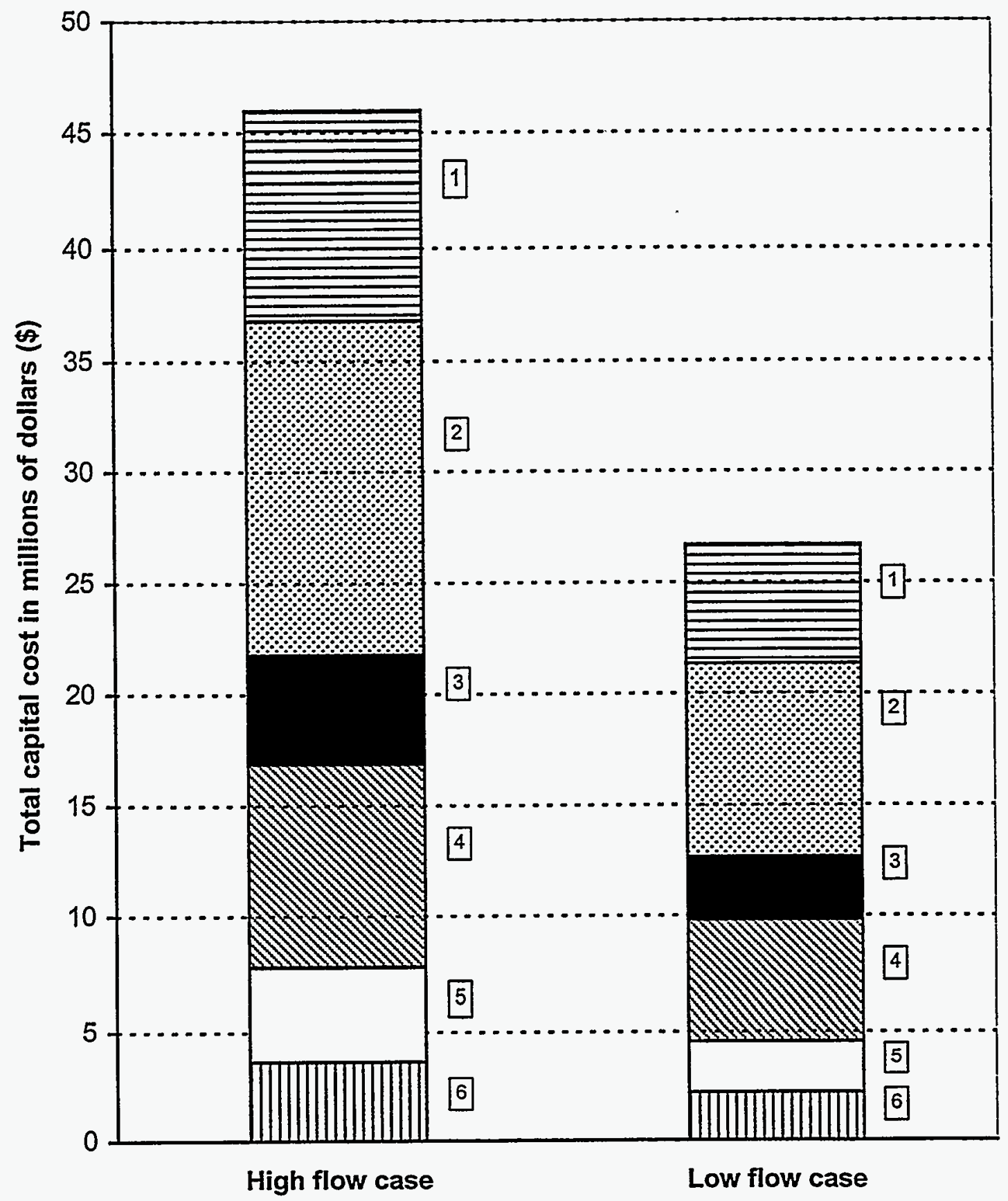

日1-Contingency

2-Facility capital costs including design, inspection, management, and allowance

3-Indirect costs

\$4-Building cost

$\square$ 5-Installation cost w/electrical, mechanical, instrumentation, and connecting ductwork 凹6-Equipment purchase cost

Figure 7-2. Breakdown of factors that determine total capital cost. 


\subsubsection{Retention Tanks}

Two variations of retention tanks were considered. The first variation was the use of evacuated retention tanks that operated over a pressure range from 0.2 to $0.9 \mathrm{~atm}$ ( -10 to $-1.3 \mathrm{psig}$ ), and the second variation used retention tanks that can be pressurized up to 100 psig. For both concepts, a retention time of 12 hours was assumed for each of three tanks. Twelve hours was considered sufficient time for any necessary sample analysis to be completed, including metals and organic analyses. Three tanks were needed so that in operation, the sequence could be as follows: One tank is being filled, while the second tank is sitting full with sample analyses in progress, and the third tank has analyses complete and is being emptied. This approach assumes that a full tank that has analyses complete can be emptied within the time required to fill a tank, regardless of whether the contents of the full tank pass air emissions limits or not. Also, any added facility costs for expediting sample analysis or performing sample analysis on-site are not included in this estimate.

The evacuated retention tank concept has the inherent safety of always operating under negative pressure, like the rest of the APCS. Also, since the offgas is vented into an evacuated area, there is less potential for moisture condensation and the gas temperature will actually decrease under assumed adiabatic conditions. However, the evacuated tank concept requires (a) much larger tank capacity, (b) cooling of the offgas to reduce the offgas volume (otherwise the tank capacity requirement would be even larger) and resultant energy costs and heat exchange equipment, (c) discharge of significant amounts of condensed (although relatively clean) water condensed from the gas upon cooling, and relatively large vacuum pumps for emptying the tanks.

The pressurized tank concept enables much smaller tank capacity because of the elevated pressure, but (a) may not be considered acceptable because of the pressurized gas, (b) may result in moisture condensation in the tanks caused by compression, (c) will cause gas temperatures to increase upon compression, and (d) requires relatively large gas compressors.

The estimated installed capital costs, including the evacuated retention tanks, are shown in Figure 7-3. The addition of the evacuated retention tanks and associated equipment (not including any additional handling equipment for the increased water condensate discharge) increases the cost of the APCS for the high-flow case by 18 times to $\$ 831$ million. The APCS cost for the low-flow case increases by 16 times to $\$ 426$ million. These are huge increases in the APCS cost.

Using pressurized rather than evacuated retention tanks can significantly reduce the total capital costs as shown in Figure 7-4 and in Table 7-1, Cases 5 and 6 . The total capital costs for the high-flow and low-flow cases (including pressurized retention tanks) are reduced to $\$ 374$ million and $\$ 167$ million, respectively. However, even these lower costs increase the costs of the baseline high-performance APCS by hundreds of millions of dollars.

Stakeholders and operators of planned mixed waste treatment facilities should seriously consider such large costs and determine if the added assurance that no unanalyzed, non-compliant emissions are released is worth the added cost. In the case of evacuated retention tanks, the added benefit is probably not worth the added costs. This is especially true for the high-performance APCS conceptualized in this report. A reasonable alternative to spending hundreds of millions of dollars extra for the retention tanks would be to spend a few million dollars more and install backup gas cleaning equipment such as added carbon and HEPA filters (which are included in alternative high-performance APCS designs in 


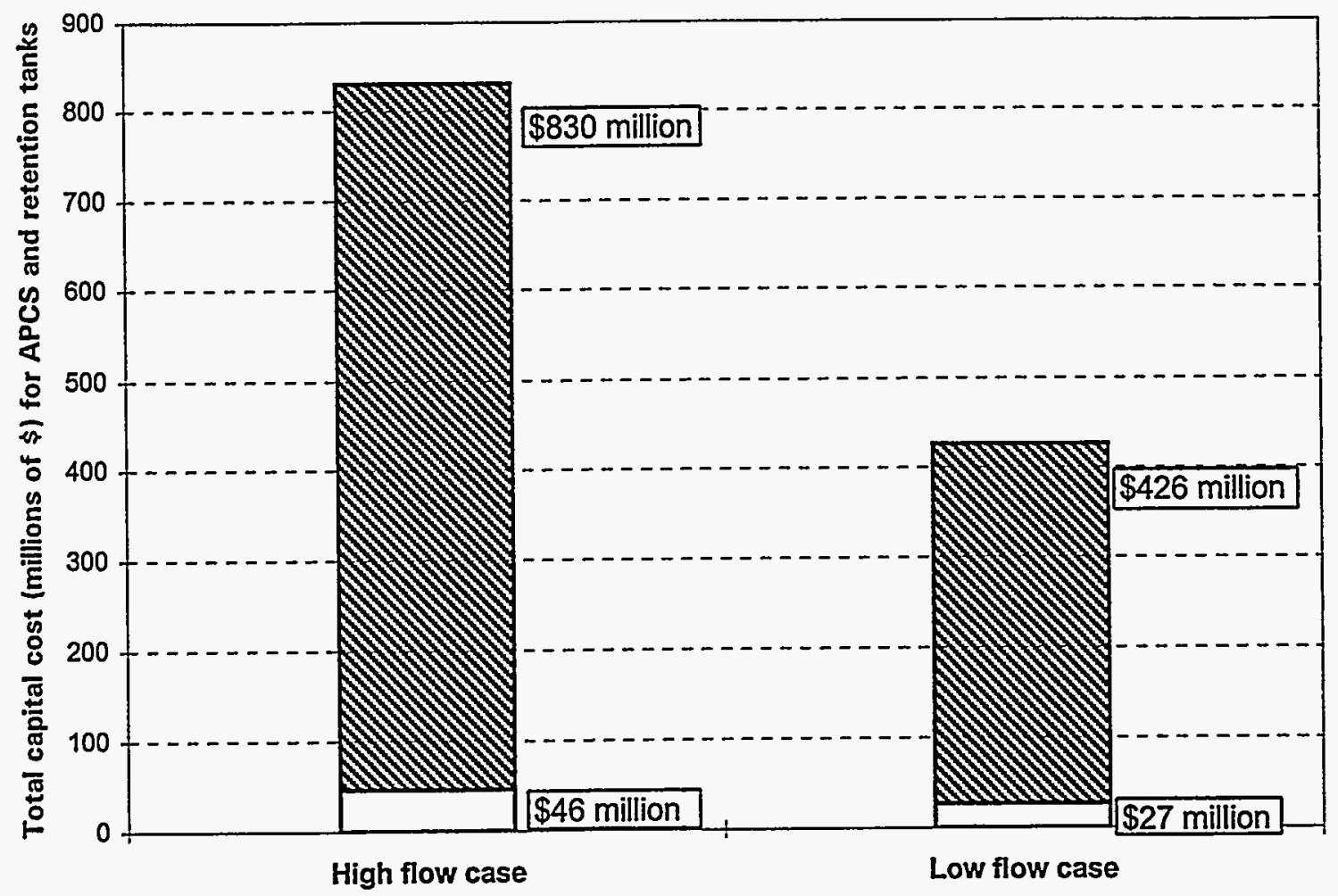

- Capital cost without tanks $\mathbf{D}$ Increased cost to include evacuated tanks

Figure 7-3. Increased capital cost due to use of retention tanks.

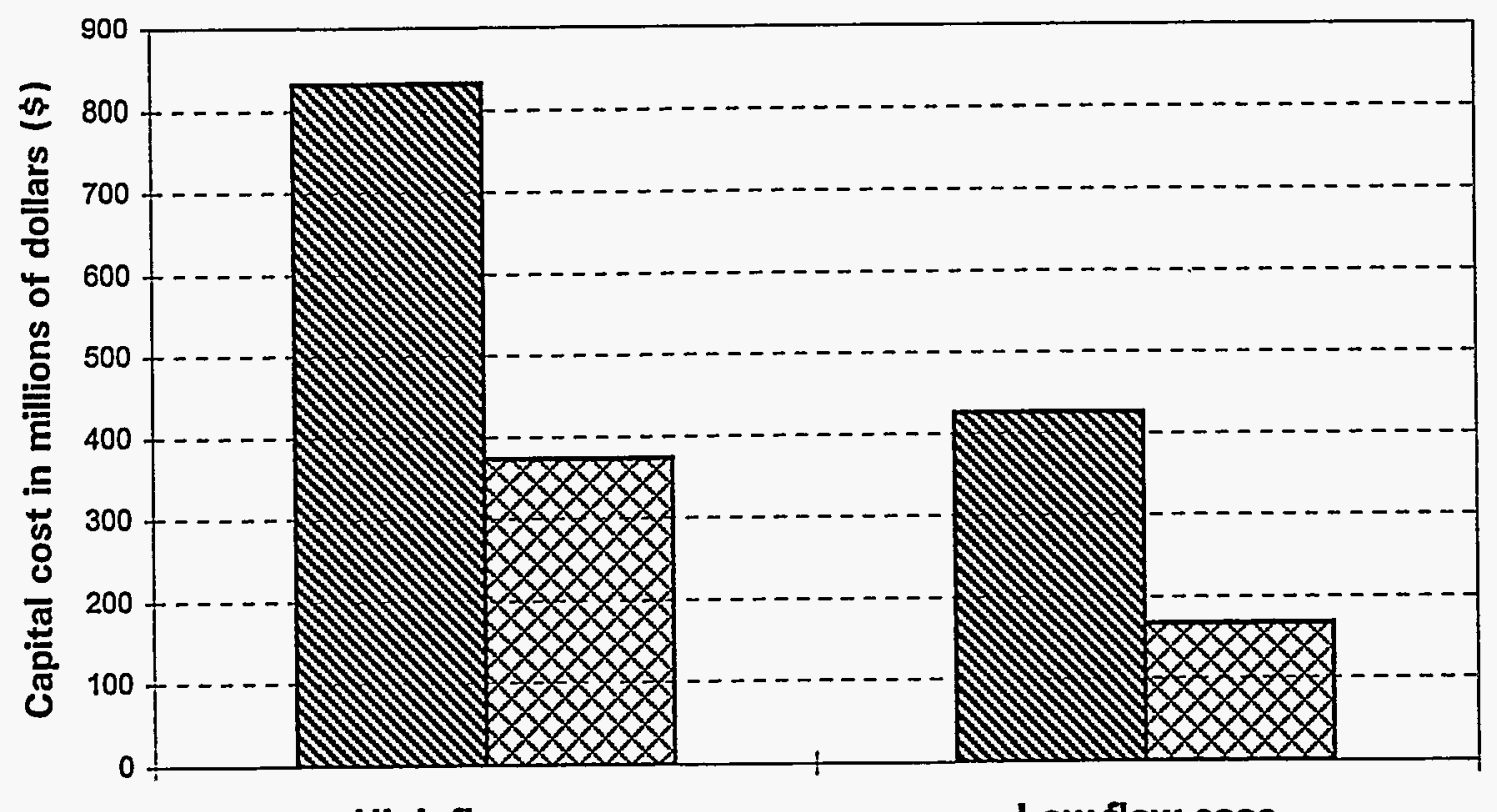

High flow case

Low flow case

NEvacuated retention tanks/vacuum pumps DPressurized retention tanks

Figure 7-4. Comparison of the cost of evacuated and pressurized retention tanks. 
Appendix B). Other alternatives (R-2 and R-3) shown in Appendix B, but not presently modeled in this study, incorporates $\mathrm{O}_{2}$ combustion and $\mathrm{CO}_{2}$ removal to further reduce the offgas volumetric flowrate. This would decrease the costs associated with the use of the retention tanks, but the cost of the $\mathrm{CO}_{2}$ removal system would have to be added to the total system. It is not likely that the chance of unanalyzed, noncompliant emissions can be prevented without adding at least $\$ 100$ million to the capital cost of the APCS. Increases in operating and lifecycle costs would need to be considered in addition to capital costs to assess how much impact this would have on total costs for the entire treatment system.

\subsubsection{Selective Catalytic Reduction $\mathrm{NO}_{\mathrm{x}}$ Control}

Many primary waste treatment processes do not produce large amounts of $\mathrm{NO}_{\mathrm{x}}$, even for waste streams that contain some nitrates that can be a source of $\mathrm{NO}_{\mathrm{x}}$. Existing and proposed federal regulations for waste treatment do not include emission limits for $\mathrm{NO}_{x}$, although state and local regulations can limit $\mathrm{NO}_{\mathrm{x}}$ emissions. If $\mathrm{NO}_{\mathrm{x}}$ emissions from the treatment process are not regulated or are within applicable emission limits, then the SCR reactor for $\mathrm{NO}_{x}$ control can be eliminated. The SCR is one of the largest single cost components for the APCS capital costs. Elimination of the SCR will decrease the APCS capital costs by $6-9 \%$ as shown in Figure 7-5. The capital cost for the high-flow case will decrease from $\$ 46$ million to about $\$ 43$ million, and the capital cost for the low-flow case will decrease from $\$ 27$ million to $\$ 24$ million, as shown in Table 7-1, Cases 7 and 8.

\subsubsection{Carbon Bed Adsorbers for Mercury Removal}

Sensitivity studies were conducted to evaluate the cost savings that would be realized without the carbon bed adsorbers. This savings is shown in Figure 7-5, and was calculated to be $\$ 9.3$ million (20\% of the total cost) for the high-flow case and $\$ 3.6$ million ( $13 \%$ of the total cost) for the $\mathrm{O}_{2}$ combustion case. The capital cost estimates for the air and $\mathrm{O}_{2}$ cases minus the carbon bed adsorbers are shown in Table 7-1, Cases 9 and 10, respectively.

\subsection{Comparison of APCS Costs to ITTS Study}

The estimated APCS capital cost for the high-flow case is $\$ 46$ million. This value is somewhat higher than the estimate of $\$ 38$ million for the APCS for air-fired rotary kiln incinerator from the ITTS study (Feizollahi 1996). The APCS from the ITTS included a larger baghouse, developmental backflushable stainless steel HEPAs, a packed bed scrubber in addition to the free-jet scrubber, and additional floorspace. Considering the component differences, the two estimates, are relatively similar. 


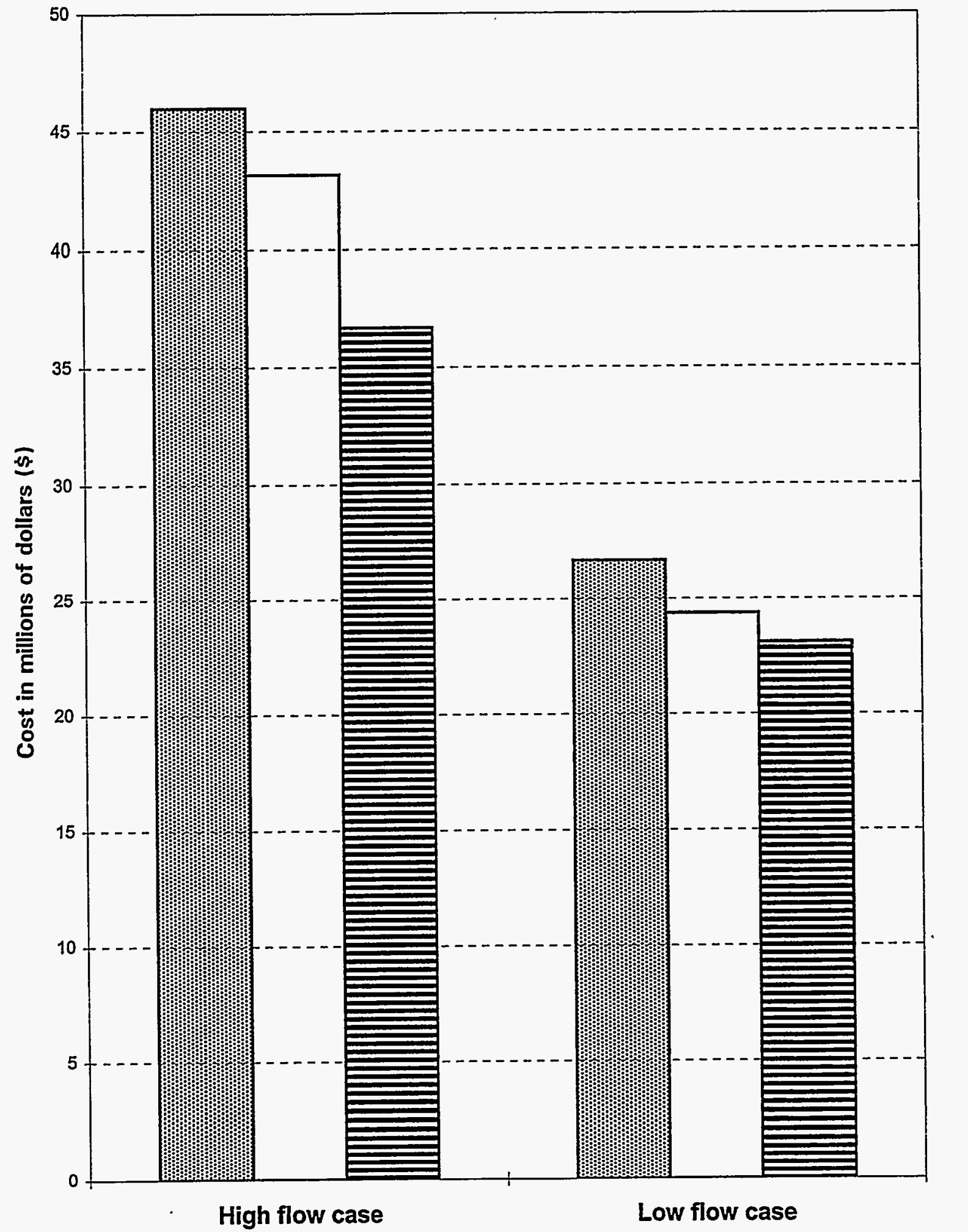

- Total capital cost $\square$ APC without NOx control DAPC without carbon adsorbers

Figure 7-5. Comparison of the cost for the complete APCS to the cost without $\mathrm{NO}_{x}$ control and without carbon adsorbers. 


\section{CONCLUSIONS AND RECOMMENDATIONS}

\subsection{Conclusions}

This study has utilized a process simulation approach to evaluate a high-performance APCS design. The study included identification of several high performance APCS designs, selection of a design for process simulation, computations of APCS performance for controlling pollutants that could be emitted in offgas produced from DOE mixed waste thermal treatment, installed capital cost estimates, and identification of potential limitations and outstanding issues of the process simulation, assumptions, and APCS performance.

\subsubsection{APCS Design and Emissions Control Performance}

- The selected high-performance APCS design easily meets expected stringent emission limits for all pollutants, except possibly mercury.

- The offgas concentrations of PM and selected metals were reduced to $10^{-1}-10^{-4}$ of current or proposed limits. This represents a significant safety factor below expected limits for these pollutants. $\mathrm{HCl}$ and $\mathrm{Cl}_{2}$ concentrations were approximately $1 / 2$ of or less than proposed limits.

- While the offgas concentration of $\mathrm{Hg}$ was around $2 / 3$ of the expected limit for the low-flow case, it was over 60 times greater than the limit for the high-flow case. The lower $\mathrm{Hg}$ emissions in the low-flow case resulted from the removal of greater quantities of water-soluble $\mathrm{HgCl}_{2}$ in the wet scrubber. Performance of $\mathrm{Hg}$ control technologies including sulfur-impregnated carbon absorption must be improved and validated to provide the level of $\mathrm{Hg}$ control (at least $99.99 \%$ ) needed if some Hg-contaminated mixed wastes are thermally treated. If such high $\mathrm{Hg}$ control efficiencies are not possible, then the $\mathrm{Hg}$ content in waste fed to mixed waste incinerators may need to be significantly limited to meet expected emission limits.

- Decontamination factors (DFs) for all semivolatile and low volatile metals except mercury for both offgas cases were on the order of $10^{\circ}$. Mercury DFs in the high-flow and low-flow cases were only 130 and 34,000 , respectively. The higher $\mathrm{Hg} \mathrm{DF}$ in the low-flow case was attributed to a higher $\mathrm{HCl}$ concentration in the offgas to form more water soluble $\mathrm{HgCl}_{2}$ which was readily removed in the wet scrubber.

\subsubsection{APCS Process Simulation Model}

- ASPEN PLUS is a powerful process simulation tool that was used to evaluate the effectiveness of an integrated APCS to minimize pollutant emissions as a function of offgas flowrates, initial pollutant concentrations, and the APCS unit operations and their operating parameters.

- The process simulation helped to identify potential system design limitations such as limited $\mathrm{Hg}$ control efficiency, insufficient offgas cooling in the low-flow case to allow adequate offgas reheat, and high frequency HEPA prefilter replacements.

- Several simplifying steps and assumptions were used in this study. These included (a) exclusion of upfront thermal treatment steps including primary thermal treatment and secondary combustion, 
(b) the use of only fully oxidized input offgas from a hypothetical SCC, (c) exclusion of specific radionuclides, products of incomplete combustion, and D/F, (d) simplification and limited range of offgas and PM flowrate and composition, and PM size distributions, (e) exclusion of secondary waste treatment options and systems, $(f)$ use of sometimes unproven vendor recommendations and assumptions for control equipment performance, (g) lack of optimization of some model results such as $\mathrm{Hg}$ control efficiency, secondary waste generation, offgas cooling, reheat, and carbon adsorber temperature limits, and $(\mathrm{h})$ the use of cost factors for estimating installed capital costs.

\subsubsection{Installed Capital Cost Estimates}

- The installed capital costs of the APCS for the high-flow and low-flow cases were estimated to be $\$ 46$ million and $\$ 27$ million, respectively. These installed capital costs are 6 times higher than the major and other equipment purchase costs, largely because of large factors needed to account for costs associated with designing, constructing, and permitting DOE facilities (facility capital costs).

- The addition of retention tanks and associated equipment is prohibitively costly. The total estimated APCS costs for the high-flow and low-flow cases using pressurized retention tanks was $\$ 374$ million and $\$ 160$ million, respectively. The total estimated APCS costs for the high-flow and low-flow cases using evacuated retention tanks was $\$ 831$ million and $\$ 426$ million, respectively.

- Not including offgas retention tanks, the most costly control equipment was the carbon adsorbers followed by the $\mathrm{NO}_{x}$ control unit and HEPA filters.

\subsection{Recommendations}

Several recommendations result from this study. These include recommendations for future APCS design, uses of the APCS process simulation developed in this study, and validation or improved performance of specific control technologies.

\subsubsection{APCS Design}

- Future APCS design for new facilities or for modifying existing facilities should consider the features of the high-performance APCS modeled in this study to provide greatest assurance of adequate emissions control.

- Offgas retention tanks for holding offgas long enough to ensure that noncompliant offgas is not emitted are not recommended. Instead, efforts should emphasize proper APCS design, installation, and operation to achieve compliance goals without the use of offgas retention and delayed offgas release.

- Significant issues identified in this study that should be addressed in future APCS designs include (a) Hg control technology capabilities and limitations, (b) optimization of offgas cooling, reheat, and carbon adsorber temperature to prevent moisture condensation in HEPAs and downstream equipment while achieving desired $\mathrm{Hg}$ removal efficiency and minimizing secondary wastes, (c) optimization of prefilter, HEPA filter, and carbon bed media replacement frequency, (d) optimization of D/F control, (e) optimization of secondary waste volume and properties, $(f)$ the impact that secondary waste treatment has on system alternatives, $(\mathrm{g})$ validation of assumptions for PM size distribution and control, and $(\mathrm{h})$ validation of metals partitioning and control. 


\subsubsection{Uses of the APCS Process Simulation}

- The engineering analysis approach, including the process simulation model, established in this study should be used to evaluate additional high-performance APC systems proposed for new facilities or as modifications to existing facilities. This process simulation model can be used in feasibility studies, preconceptual and conceptual designs, technology development and validation programs, and to support higher-level waste flow analyses.

- Using this process simulation can help provide (a) better information for decisions about alternatives for existing mixed waste treatment facilities to comply with new regulations, (b) better identification and qualification of incomplete performance and cost information for new or existing technologies, (c) better public, regulatory, and stakeholder acceptance of thermal treatment and APC systems based on more definitive performance evaluations, (d) avoidance of costly and unnecessary features such as offgas retention, and (e) more rapid and less costly implementation of new facilities and needed modifications to existing treatment facilities.

- Parametric studies should be conducted to identify the impact of variations in offgas or waste feed conditions, new APCS equipment such as improved $\mathrm{Hg}$ control technologies, improved or validated control equipment performance data, and operating parameters on pollutant emissions and life-cycle costs for a given APCS. Parametric studies should also be conducted to optimize $\mathrm{Hg}$ control efficiency, secondary waste generation, offgas cooling, reheat, and carbon adsorber temperatures, and APCS costs.

- The process simulation should be upgraded to include (a) upstream thermal treatment steps such as primary thermal treatment and secondary combustion so the process simulation can determine species partitioning and offgas generation from the thermal treatment system as functions of the waste feed content and thermal treatment equipment design and operation, (b) modeling of specific radionuclides, products of incomplete combustion, and D/F, and (c) downstream secondary waste treatment and disposition options. Inclusion of upstream and downstream processes in the entire system would evolve this APCS simulation into a complete simulation of the entire treatment system. This would provide better identification of any issues that could impact different unit operations in the entire system, and enable optimization of the entire system to meet system objectives.

- A process simulation of candidate wet-dry high-performance APCS designs should be done to better identify and quantify advantages, disadvantages, and issues for wet-dry systems as compared to the dry-wet system modeled in this study.

- $\quad$ Cost estimates should be upgraded to focus on lifecycle costs which include capital costs and operating costs over some facility lifecycle.

\subsubsection{Control Technology Improvement and Validation}

- Existing and new Hg control technologies need to be improved and validated to provide assurance that mixed waste thermal treatment facilities can meet expected $\mathrm{Hg}$ emission limits while processing some $\mathrm{Hg}$-containing mixed waste streams. If such validation is not possible, then 
restrictive $\mathrm{Hg}$ feed limits (and feed characterization for $\mathrm{Hg}$, with the associated uncertainties and risks) will be required for existing and new thermal treatment facilities.

Additional performance information should be obtained to validate model assumptions concerning (a) $\mathrm{Hg}$ removal efficiency in carbon beds, (b) PM and $\mathrm{Hg}$ removal in the wet scrubber, (c) possible $\mathrm{D} / \mathrm{F}$ formation in the SCR reactor, and (d) cumulative impacts of multiple APC equipment connected in series. 


\section{REFERENCES}

Biagi, C., et al, 1997, Integrated Nonthermal Treatment System Study, Final Draft, INEL/EXT-96-0273, Idaho National Engineering Laboratory.

Branter C., D. Conley, and P. Gray, 1994, "Facility Status and the Second Trial Burn of the INEL's WERF Mixed and LLW Incinerator," Proceedings of the 1994 Intl Incineration Conference, Houston, TX, 355 358.

Brown, B. W., 1995, Carbon Dioxide Management, unpublished report, Idaho National Engineering Laboratory.

Burchsted C. A., J. E. Kahn, and A. B. Fuller, 1979, Nuclear Air Cleaning Handbook: Design, Construction, and Testing of High-Efficiency Air Cleaning Systems for Nuclear Application, ERDA 76-21, Oak Ridge National Laboratory.

Burns H. H. and D. B. Burns, 1997, "Lessons Learned from Start-up Testing of a Mixed Waste Incinerator," Proceedings of 1997 Intl Conf. on Incineration and Thermal Treatment Technologies, Oakland, CA, 181-184.

Christian, J. D., R. C. Girton, B. E. Kirstein, and D. T. Pence, 1978, R\&D for an Offgas Treatment System for a Slagging Pyrolysis Radioactive Waste Incinerator, Final Report for Phase II, SAI78-904-LJ, Science Applications, Inc.

Dalton, D., E. M. Steverson, and G. L. Anderson, 1992, Air Pollution Control in Thermal Treatment, EGG-WTD-10038, Idaho National Engineering Laboratory.

Dalton, J. D., W. P. Wolfe, and R. M. Geimer, 1994, Air Pollution Control System Flowsheet for the PilotScale PHP System, SAIC-94/1042, Science Applications Intl Corp.

Dirks, F., Karlsruhe Nuclear Research Center, personal communication to N. R. Soelberg, June 3, 1996.

DOE 1993, U.S. Department of Energy Interim Mixed Waste Inventory Report: Waste Streams, Treatment 'Technologies, Treatment Capacities and Technologies, DOE/NBM-1100.

EER (Energy and Environmental Research Corporation), 1992, APC and Monitoring Technologies for Rocky Flats Fluidized Bed Unit, State of the Art Assessment, EPA Contract 68-CO-0094.

EER (Energy and Environmental Research Corporation) 1997, Demonstration Testing for Mixed Waste Thermal Treatment Technologies, interim final draft, sponsored by the National Technical Workgroup on Mixed Waste Thermal Treatment.

EPA 1992, Operations and research at the U.S. EPA Incineration Research Facility: Annual Report for FY91, EPA/600/R-92/051.

EPA 1996, Revised Standards for Hazardous Waste Combustors, 61 Federal Register 17358, April 19. 
EPA 1997a, EPA Notice of Data Availability for Revised Technical Standards for Hazardous Waste Combustors, 62 Federal Register pp 24212ff, May 2.

EPA 1997b, Total Mercury and Particulate Continuous Emissions Monitoring Systems; Measurement of Low Level Particulate Emissions; Implementation at Hazardous Waste Combustors; Proposed Rule-Notice of Data Availability and Request for Comments, 62 Federal Register 67788-67818, December 30.

EPA 1997c, Draft Technical Support Document for HWC MACT Standards (NODA), Volume 1: MACT Evaluations Based on Revised Database, April.

Eddy, T. L., B. D. Raivo, N. R. Soelberg, and O. Weirsholm, 1995, Advanced Mixed Waste Treatment Project Melter System Preliminary Design Technical Review Meeting, INEL-95/0054, Idaho National Engineering Laboratory.

Feizollahi, F. and W. J. Quapp, 1996, Integrated Thermal Treatment System Study-Phase 2 Results, INEL-95/0129, Rev. 1, Idaho National Engineering Laboratory.

Huebner, T. L., J. M. Wilson, A. H. Ruhter, and S. J. Bonney, 1994, Quantities and Characteristics of the Contact-Handled Low-Level Mixed Waste Streams for the DOE Complex, EGG-MS-11303, Idaho National Engineering Laboratory.

IAEA, 1989, Treatment of Offgas from Radioactive Waste Incinerators, International Atomic Energy Agency Technical Report Series No. 302, Vienna.

LMITCO (Lockheed Martin Idaho Technology Company), 1997, Mixed Waste Characterization Reference Document, Draft, June.

Liekhus, K., J. Grandy; A. Chambers, N. Soelberg, and G. Anderson, 1997, Partitioning Planning Studies: Preliminary Evaluation of Metal and Radionuclide Partitioning in High-Temperature Thermal Treatment Systems, INEL/96-0450, Idaho National Engineering Laboratory.

MSE, 1994, Closed Loop Off-gas Test Bed Order of Magnitude Estimate Design and Recommendations Report, unpublished report, MSE Inc.

MSE, 1995, Plasma Arc Centrifugal Treatment Test Plan - Controlled Emission Demonstration Slip Stream Test Bed - Shakedown and Demonstration Tests, MSE Inc.

O'Connor, W. K., L. L. Oden, P. C. Turner, N. R. Soelberg, A. G. Chambers, and G. L. Anderson, 1995, Graphite Electrode Arc Melter Demonstration Phase 2 Test Results, INEL-95/0502, Draft, Idaho National Engineering Laboratory.

Peters, Max S. and Klaus D. Timmerhaus, 1991, Plant Design and Economics for Chemical Engineers, Fourth Edition, McGraw-Hill, Inc., New York.

Roberts, D.L., 1995, "Design of a Sorbent-Based Process for Removal and Recovery of Mercury Vapor from Incinerator Flue Gases," Intl. Incineration Conf., Bellevue, WA. 
Sarofim, A. F., M. C. Flemings, J. W. Tester, I. G. Senel, and J. Benavides, 1997, Application of Solution Thermodynamics and Solution Dynamics to Enhance Residue Segregation in Molten Metal Waste Processing, 2nd Annual Progress Report, Massachusetts Institute of Technology, Prepared for the INEEL University Research Consortium, July.

Senior C. L., et al., 1997, "A Fundamental Study of Mercury Partitioning in Coal Fired Power Plant Flue Gas," Proceedings of AWMA Annual Mtg, 97-WP72B.08, Toronto.

Soelberg, N. R., and W. J. Quapp, 1994, "Size Reducing Radioactive Wastes for Treatment Processes," Spectrum '94 Nuclear and Hazardous Waste Management International Topical Meeting, Atlanta, GA, August 14-18.

Soelberg, N. R., 1996a, Karlsruhe Nuclear Research Center (KfK) Incineration Facilities and Experience, unpublished document, Idaho National Engineering Laboratory.

Soelberg, N. R., 1996b, Offgas System Equipment and Design for Mixed Waste Treatment, unpublished document, Idaho National Engineering Laboratory.

Soelberg, N. R., A. G. Chambers, G. L. Anderson, W. K. O'Connor, L. L. Oden, and P. C. Turner, 1996c, Graphite Electrode Arc Melter Demonstration Phase 2 Test Results, INEL-95/0502, Idaho National Engineering Laboratory.

Soelberg, N. R., A. G. Chambers, J. D. Grandy, K. L. Liekhus, and G. L. Anderson, 1997a, "Metals, particulate, and Radionuclide Partitioning Results from Mixed Waste Thermal Treatment Demonstrations," Proceedings of 1977 International Conf. on Incineration and Thermal Treatment Technologies, Oakland, CA, 769-782.

Soelberg, N., A. Chambers, and R. Kimmitt, 1997b, Acceptance Criteria for the Pit 9 Plasma Melter Limited Production Test, unpublished document, Idaho National Engineering Laboratory.

Soelberg, N. and A. Chambers, 1997c, Report of Preliminary Mercury Emissions Control Study for Mixed Waste Treatment, unpublished internal draft INEEL report, December.

Tidona, R. J. and S. H. McHale, 1997, "The HWC MACT Rule: What does it mean to me?", Proceedings of 1997 Intl Conf. on Incineration and Thermal Treatment Technologies, Oakland, CA, 115-118.

Wark, K. and C.F. Warner, 1981, “Air Pollution: Its Origin and Control," 2 ed., Harper Collins, New York. 


\section{APPENDIX A.}

Offgas Flowrates and Compositions for the Offgas System Conceptual Design and Evaluation Project 
A-2 


\title{
OFFGAS FLOWRATES AND COMPOSITIONS FOR THE OFFGAS SYSTEM CONCEPTUAL DESIGN AND EVALUATION PROJECT
}

\author{
September 20, 1996 \\ Nick Soelberg
}

The Offgas System Conceptual Design and Evaluation Project is being conducted to identify and evaluate various traditional and innovative offgas management systems that are most promising for reliably and efficiently controlling air emissions from mixed waste thermal treatment systems. The scope of the study includes:

- Conceptualizing several different offgas management systems for controlling all of the expected pollutants in the offgas from mixed waste thermal treatment systems, such as included in the Integrated Thermal Treatment Systems study (Feizollahi, F. and W. J. Quapp, Integrated Thermal Treatment System Study - Phase 2 Results, INEL-95/0129, Revision 1, February 1996).

- Evaluating the conceptualized systems in terms of performance data and estimates, operating and maintenance information, implementation risk (potential for successful development and implementation), mass and energy balances, and characteristics and disposal of secondary waste streams. The most promising systems will be identified based on their technical merit. Equipment size estimates and cost estimates will be conducted for those with the most technical merit.

\section{Potential Variations in Input Offgas Flowrates and Compositions}

The design and performance of any offgas system depends on the properties of the offgas to be treated. The properties of the offgas depend on the properties and processing rate of the input waste, any additives, and the design and operation of the primary treatment system. There are 19 different treatment systems included in the ITTS evaluations. These are listed from Feizollahi 1996 in Table A-1 of Appendix A. This table shows the input feedrates for the systems. The baseline waste inputs to the main thermal treatment or thermal desorption systems range from 1,949 to $2,617 \mathrm{lb} / \mathrm{hr}$. The breakdown of the waste materials is shown in Table A-2 of Appendix A, and compositions of each of these waste streams are provided in Feizollahi 1996.

The flowrates of offgas into each offgas system for the main thermal treatment system range from 399 to $28,241 \mathrm{lb} / \mathrm{hr}$. This variation is because of the differences in amounts and kinds of waste feed to the main thermal treatment system, use of oxygen or air for oxidizing organics, operation in a pyrolysis mode or an oxidizing mode, use of added water spray evaporation for temperature control where needed, use of electrical energy input or auxiliary fossil fuels where needed, and use of offgas recycling.

Systems G-1 and $\mathrm{H}-1$ produce a synthesis gas that requires treatment in an offgas system prior to full oxidation. The synthesis gas composition for these two systems is much different from the oxidized offgas produced in the other systems. Offgas systems from fully oxidizing waste treatment systems (the more likely DOE approach) will be considered first in the Offgas System Conceptual Design and Evaluation Project, so gas compositions and flowrates for systems G-1 and $\mathrm{H}-1$ are not included in this document. The offgases produced from the $\mathrm{K}-1$ and $\mathrm{L}-1$ thermal desorber systems are also not included in this document, because of the differences in offgas composition and handling methods. 
Table A-1. Input feed rates for nineteen systems (Ib/hr) (from Feizollahl 1996).

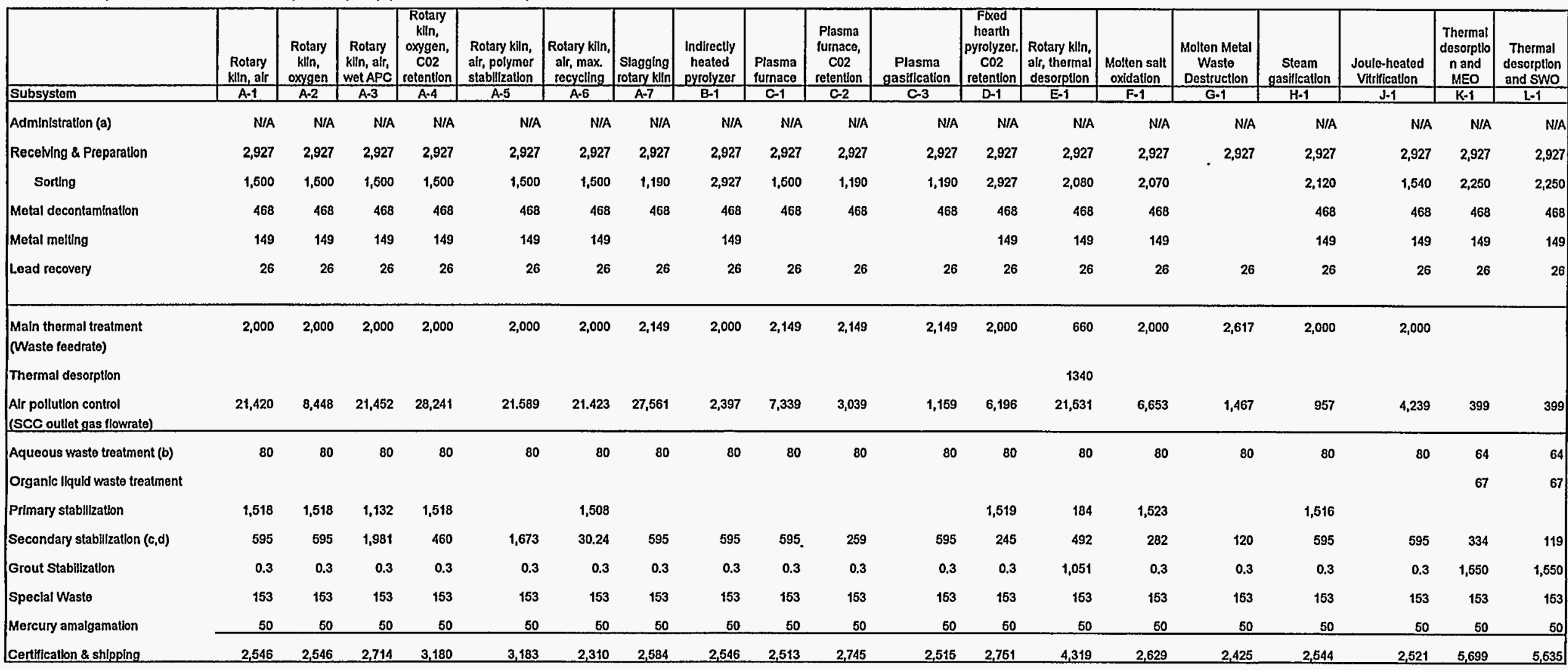

a. The Input feed rate is not applicable to the administration subsystem.

b. The aqueous waste feed rate shown above only accounts for prlmary feed stream from receling and shlpplng and does not account for secondary aqueous waste streams and recycle streams which valles on a system by system basls.

c. The feed to secondary stablization is comprised of concentrated sludge from aqueous waste treatment, trace metals, and spent IIme from APC, sludge contalning surface metal grit from metal decontamination and sulfate salts from receling and shippling Ikquilds from SCWO, and sollds from MEO.

d. The siudge waste Input to secondary stabillzation trom aqueous waste treatment is $20 \%$ salts and sollds by welght. In the case of system A-4, C-2, and D-1 $10 \%$ of the used lime is routed to polymer stabilization. 
Table A-2. Breakdown of mixed wastes processed in each system.

\begin{tabular}{lc}
\hline Waste Material & Feedrate, lb/hr \\
\hline Combustible waste & 660 \\
Noncombustible waste & 1,340 \\
$\begin{array}{l}\text { Combustible and noncombustible waste subtotal (feed to most of the main thermal } \\
\text { treatment systems - A-1 to A-6, B-1, D-1, F-1, H-1, and J-1) }\end{array}$ & 2,000 \\
$\begin{array}{l}\text { Metal waste with entrained contamination (included in some main thermal treatment } \\
\text { systems - A-7, C-1 to C-3, and G-1 ) }\end{array}$ & 149 \\
$\begin{array}{l}\text { Metal waste that is decontaminable (included only in the G-1 main thermal treatment } \\
\text { system) }\end{array}$ & 468 \\
Lead waste (not included in any of the main thermal treatment systems) & 26 \\
$\begin{array}{l}\text { Aqueous waste (not included in any of the main thermal treatment systems, but partly } \\
\text { included in the thermal desorption systems) }\end{array}$ & 80 \\
Special waste (not included in any of the main thermal treatment systems) & 153 \\
Mercury waste (not included in any of the main thermal treatment systems) & 50 \\
Grout stabilization waste (not included in any of the main thermal treatment systems) & 0.3 \\
Total waste processed in main thermal treatment and other subsystems & 2,927 \\
\hline
\end{tabular}

\section{Recommended Offgas Flowrates and Compositions}

The range of systems that fully oxidize the offgas is generally well represented by systems A-7 (Slagging rotary kiln, air combustion) and $\mathrm{C}-2$ (Plasma furnace, oxygen combustion and $\mathrm{CO}_{2}$ retention). The offgas compositions and flowrates for these two systems are shown in Tables A-3 and A-4. Table A-3 also shows the particulate flowrate and composition determined from ASPEN mass and energy balances for the A-7 and C-2 systems. These particulate compositions are estimated using some simplifying assumptions as inputs to the ASPEN program, and actual particulate will likely include many species not included here such as chlorides, sulfur species, possibly some carbonates and some unburned carbon, some fluorides, and many other elements including $\mathrm{Mg}, \mathrm{Mn}, \mathrm{P}, \mathrm{Ti}$, and $\mathrm{Zn}$. Table A-4 also includes offgas flowrate and composition information from other similar studies for comparison. Most of the values are similar or within reasonable ranges, except for the high levels of total particulate estimated in the ITTS study. These levels resulted from a somewhat arbitrary calculation of total particulate in the offgas as $20 \%$ of the inorganic material processed in the primary treatment unit (kiln, melter, etc). This approach may overestimate the likely amounts of total particulate.

The bolded columns in Table A-4 show recommended flowrates and compositions for use in this study. These two sets of flowrate and composition data are based on whether oxygen or air is used for 
Table A-3. Flowrate at the secondary combustion chamber outlet from Feizollahi 1996 (a).

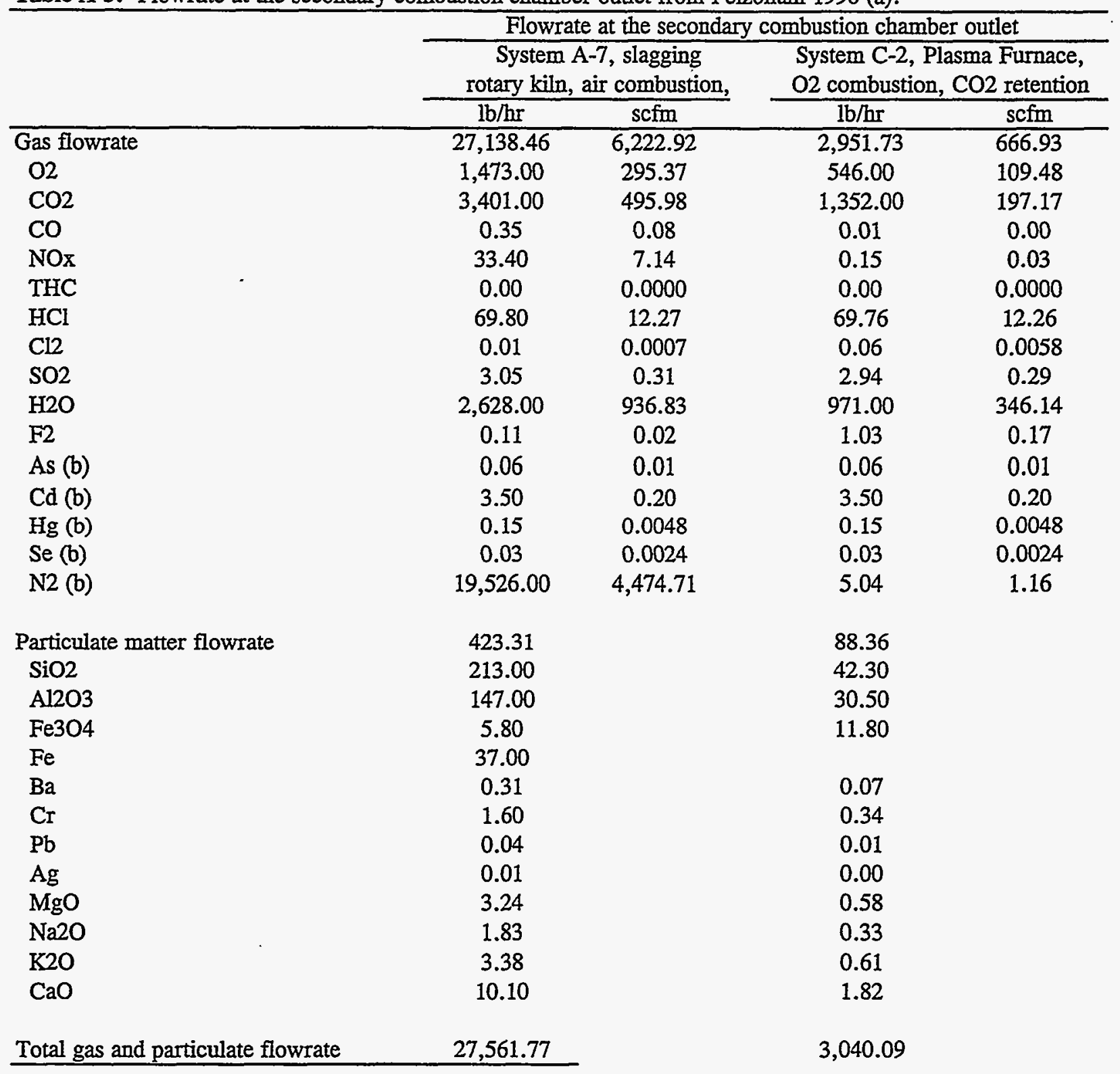

a. Unpublished documentation for Feizollahi, F. and W. J. Quapp, Integrated Thermal Treatment System Study - Phase 2 Results, INEL-95/0129, Revision 1, February 1996.

b. $100 \%$ of all input amounts of these species was assumed to volatilize to a gas in the primary treatment process in the ITTS study. These should be included in total particulate values. 
Table A-4. Offgas flowrates and compositions for selected ITTS and other systems.

\begin{tabular}{|c|c|c|c|c|c|c|c|c|c|c|c|c|c|c|c|c|c|}
\hline & \multicolumn{11}{|c|}{ Flowrate and composition at the secondary combustion chamber outlet } & \multirow{3}{*}{\multicolumn{2}{|c|}{$\begin{array}{l}\text { Stack gas emission } \\
\text { Ievcls (dry. @ 7\% 02 }\end{array}$}} & \multirow{3}{*}{\multicolumn{4}{|c|}{$\begin{array}{c}\text { Necessary total control efficiencies, \%, } \\
\text { to mect target cmission levels }\end{array}$}} \\
\hline & \multirow{4}{*}{$\begin{array}{l}\text { System A-7, } \\
\text { slagging } \\
\text { rotary kiln, air } \\
\text { combustion (a) }\end{array}$} & \multirow{4}{*}{$\begin{array}{l}\text { Systcm C-2, } \\
\text { Plasma } \\
\text { Furnace, } 02 \\
\text { combustion (a) }\end{array}$} & \multirow{4}{*}{$\begin{array}{c}\text { Graphite } \\
\text { clectrode } \\
\text { melters (b) }\end{array}$} & \multirow{4}{*}{$\begin{array}{c}\text { Rotary } \\
\text { Kilns (b) }\end{array}$} & \multirow{4}{*}{$\begin{array}{c}\text { Plasma } \\
\text { torch } \\
\text { Mclters (b) }\end{array}$} & \multirow{2}{*}{\multicolumn{6}{|c|}{$\begin{array}{l}\text { Flowrates and composittons recommended } \\
\text { for the Offgas System Conceptual } \\
\text { Design and Evaluation Project (c) }\end{array}$}} & & & & & & \\
\hline & & & & & & & & & & & & & & & & & \\
\hline & & & & & & \multicolumn{3}{|c|}{ Air combustion (d) } & \multicolumn{3}{|c|}{02 combustion (e) } & \multirow{2}{*}{$\begin{array}{l}\text { Normal } \\
\text { (target) }\end{array}$} & \multirow{2}{*}{$\begin{array}{l}\text { Max. } \\
\text { (regulatory } \\
\text { limil) }(f)\end{array}$} & \multicolumn{2}{|c|}{ Air combustion } & \multicolumn{2}{|c|}{ O2 combustion } \\
\hline & & & & & & Normal & Min & Max & Normal & Min. & Max. & & & Normal & Max. & Normal & Max. \\
\hline Gas flowratc, $1 \mathrm{~b} / \mathrm{hr}$ & 27,138 & 2,952 & $2,900-20,700$ & & & 27,000 & 18,000 & 30,000 & 5,000 & 3,000 & 20,000 & & & & & & \\
\hline Gas flowrate, $\mathrm{kg} / \mathrm{hr}$ & 12,336 & 1,342 & $1,300 \cdot 9,400$ & & & 12,273 & 8,182 & 13,636 & $\mathbf{2 , 2 7 3}$ & 1,364 & 9,091 & & & & & & \\
\hline Gas flowrate, scfm (@ 68 F, 1 atm & 6,223 & 667 & $470-3,100$ & & & 6,044 & 4,029 & 6,715 & 857 & 514 & 3,429 & & & & & & \\
\hline Gas flowratc, dscm @ 7 \% O2 & 150 & 9 & & & & 154 & 108 & 152 & 6 & 6 & 19 & & & & & & \\
\hline Gas temperature, degrees $\mathrm{F}$ & 2,500 & 2,200 & & & & 2,200 & 1,800 & 2,400 & 2,200 & 1,800 & 2,400 & & & & & & \\
\hline \multicolumn{18}{|l|}{ Gas Composition (wet volumetric basis) } \\
\hline $02, \%$ & 5 & 16 & 7 & & & 7 & 4 & 8 & 14 & 10 & 16 & & & & & & \\
\hline $\mathrm{CO} 2 \%$ & 8 & 30 & 2.3-41 & & & 8 & 5 & 10 & 30 & 20 & 40 & & & & & & \\
\hline $\mathrm{CO}, \mathrm{ppm}$ & 13 & 3 & 10 & 50 & 40 & 5 & 1 & 10 & 5 & 1 & 10 & 40 & 100 & 0.0 & 0.0 & 0.0 & 0.0 \\
\hline NOx, ppm & 1,148 & 48 & $50-500$ & $50-500$ & $1,000-10,000$ & 1,000 & 400 & 4,000 & 1,000 & 400 & 4,000 & & & & & & \\
\hline THC, ppm & 0 & 0 & 10 & 10 & 5 & 2 & 1 & 5 & 1 & 0.5 & 5 & 0.1 & 12 & 95.5 & 98.2 & 97.5 & 99.5 \\
\hline $\mathrm{HCl}, \mathrm{ppm}$ & 1,972 & 18,388 & $72-34,000$ & 4,900 & 250 & 2,000 & 500 & 2,500 & 20,000 & 5,000 & 25,000 & & & & & & \\
\hline $\mathrm{Cl} 2, \mathrm{ppm}$ & 0 & 9 & $0-170$ & & & 2 & 0.5 & 5 & 10 & 10 & 100 & & & & & & \\
\hline Total $\mathrm{HCl}$ and $\mathrm{Cl} 2$, ppm & & & & & & 2,002 & 501 & 2,505 & 20,010 & 5,010 & 25,100 & 30 & 67 & 98.7 & 98.8 & 99.96 & 99.97 \\
\hline SO2, ppm & 49 & 442 & $0-1,200$ & 40 & 20 & 50 & 10 & 100 & 500 & 100 & 1,000 & & & & & & \\
\hline $\mathrm{H} 2 \mathrm{O}, \%$ & 15 & 52 & $5.8-76$ & & & 10 & 5 & 20 & 50 & 20 & 60 & & & & & & \\
\hline N2., \% & 72 & 0 & & & & 75 & 60 & 80 & 4 & 2 & 10 & & & & & & \\
\hline Total, \% & 100 & 100 & & & & 100 & & & 100 & & & & & & & & \\
\hline Gas molecular wcight & & & & & & 28.7 & & & 37.4 & & & & & & & & \\
\hline Total particulate matter, lb/hr (g) & 427 & 92 & 10.50 & & & 107 & 21 & 215 & 43 & 21 & 215 & & & & & & \\
\hline Total particulate matter, $\mathrm{kg} / \mathrm{hr}$ & 194 & 42 & $4.5-23$ & & & 49 & 10 & 98 & 20 & 10 & 98 & & & & & & \\
\hline Total particulate conc., mg/dscm & 21,591 & 43,445 & $500-2,500$ & 11,000 & 200 & 5,283 & 1,501 & 10,698 & 53,629 & 27,932 & 83,795 & 2 & 69 & 99.962 & 99.981 & 99.996 & 99.998 \\
\hline
\end{tabular}

a. Feizollahi, F. and W. J. Quapp, Integrated Thermal Treatment System Study - Phase 2 Results, INEL-95/0129, Revision 1, February 1996.

b. Soelberg N, G. Anderson, and B. Raivo, Offgas System Equipment and Design for Mixcd Wastc Treatment, unpublished draft report, Idaho National Engineering Laboratory, July 1996 . The flowrates from Soclberg 1996 are for a waste feedrate of $1,000 \mathrm{~kg} / \mathrm{hr}$, slightly larger than the waste fedrate of 2,000 $\mathrm{lb} / \mathrm{hr}$ of Feizollahi 1996. Also, the waste compositions used in Soelberg 1996 are slightly different than used in Feizollahi 1996, and oxygen was used for combustion rather than air. Other notes regarding the Soelberg 1996 data are shown in Soclberg 1996.

c. This composition and flowrate is meant to generally encompass the compositions and flowrates from the ITTS systems. Some specific systems may have somewhat different values. The pyrolysing systems that result in a synthesis gas that is processed in an offgas system and then oxidized arc excluded, duc to the different flowrates and compositions.

d. The air-fired minimum gas flowrate values are $60 \%$ of the maximum value, a typical allowable turndown for offgas equipment.

c. The 02-fired minimum gas flowrates were determined by mass/cnergy balance based on the offgas generated from different potential waste feed extremes. The gas flowrates vary so widely because of the potential need for added air, inert gas, water/steam, or offgas recycle to control peak temperatures. Since these minimum values are lower than a typical $60 \%$ of the maximum values, added air, inert gas, or offgas recycle may be required for adequate offgas equipment performance.

f. From EPA, The Revised Standards for Hazardous Waste Incinerators, March 1996, Proposed MACT Standards for New Incineralors.

g. The recommended particulate levels range from $5 \%$ (normal), $1 \%$ (minimum), and 10\% (maximum) of the design ITTS feedrate of 2,149 $16 / \mathrm{hr}$ waste feed input for the baseline ITTS systems. 
combustion, and include estimated normal, minimum, and maximum concentration and flowrate levels. These estimates should be used in conceptual design and evaluation of innovative offgas systems for thermal treatment processes that fully oxidize the offgas produced from treating approximately $2,000 \mathrm{lb} / \mathrm{hr}$ of wastes similar to the wastes used in the ITTS study.

Using these recommended values enables offgas systems to be evaluated based on how well they control the range of specified offgas flowrates, temperatures, and compositions, without being associated to any of the specific primary treatment systems. This will enable evaluation of different offgas systems on their own merit for two different general offgas conditions (from air combustion and fossil-fired heat generation and from oxygen combustion and electrical heat generation) rather than on how well they perform for a given treatment system. The mass flowrate and most of the concentration values are orderof-magnitude values that are similar to the values shown for the A-7 or C-2 systems, with some exceptions. These exceptions are:

- Volumetric gas flowrate: The recommended offgas volumetric flowrates were calculated using the mass flowrates and the molecular weights determined from the gas compositions.

- THC: Total hydrocarbons (THC) were not included in the ITTS Phase 2 mass balances. A THC level of 0 is not realistic, so reasonably achievable ranges of $0.5-5 \mathrm{ppm}$ were used in the recommended compositions.

- $\quad \mathrm{N}_{2}$ : While no $\mathrm{N}_{2}$ is estimated in the C-2 system, such a low value is not realistic considering potential air inleakage, feeder purge air or $\mathrm{N}_{2}$, and air or $\mathrm{N}_{2}$ in interstitial spaces in the waste itself. The $\mathrm{N}_{2}$ concentration for both recommended compositions was determined by difference from $100 \%$ of the sum of the other gas species.

- Total particulate: The recommended values are based on order-of-magnitude estimates of carryover as a percent of the total feed input, ranging 1,5 , and $10 \%$ of the feed input for the minimum, normal, and maximum carryover for air-fired systems, and 1,2 , and $10 \%$ for $\mathrm{O}_{2}$-fired systems. Carryover for the normal condition for the $\mathrm{O}_{2}$-fired case was assumed to be less than for the normal air-fired case to be consistent with the significantly lower gas flowrates (and potentially lower entrainment).

Table A-4 also shows expected stack gas emission levels based on reasonable capabilities of the proposed offgas systems, and the proposed MACT Rule. While the ITTS Phase 1 and Phase 2 studies arbitrarily set a safety factor for routine operation that was 10 times lower than most of the expected emission limits, the difference between the normal and regulatory emission levels in this document were based more on the expected performance capability of the offgas systems. The normal target levels ranged from under $1 / 2$ of the limit (for $\mathrm{CO}$ and total $\mathrm{HCl}$ and $\mathrm{Cl}_{2}$ ) to 120 times lower (for THC). Table A-4 also shows the necessary control efficiencies to enable the normal and maximum SCC levels to be reduced to the normal stack gas levels. This way, there is still a safety factor of from around 2-120 in meeting the expected emission limits even for the maximum SCC outlet concentrations.

The recommended metals emission levels are calculated on Table A-5. Concentrations and mass emission rates in the offgas were calculated using the (a) estimated amounts of the metals in the DOE mixed low-level waste inventory, (b) average and maximum reasonable expected concentrations in 
Table A-5. Recommended metals and particulate flowrates and concentrations.

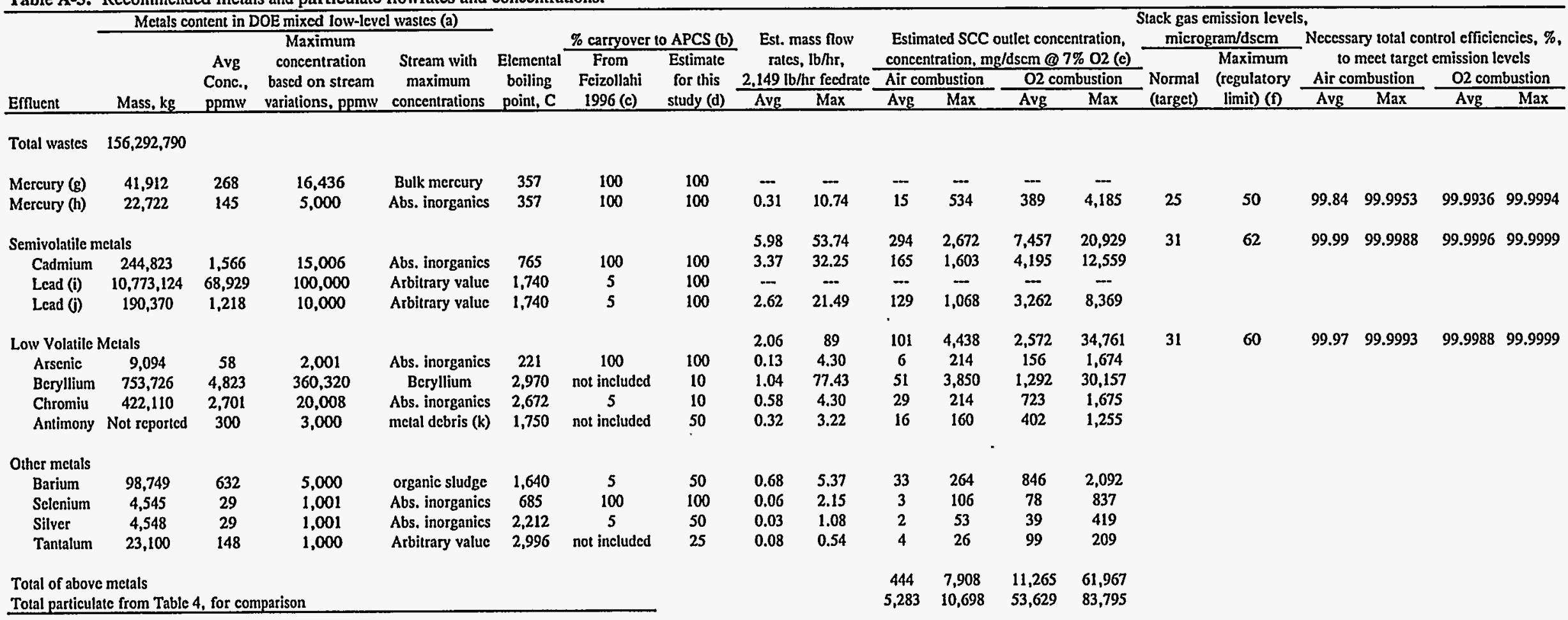

a. Huebner, T. L., J. M. Wilson, A. H. Ruhter, and S. J. Bonney, Quantities and Characteristics of the Contact-Handled Low-Level Mixed Waste Streams for the DOE Complex, EGG-MS-11303, August 1994.

The values shown here are directly from Huebner 1994 spreadsheets. The implied number of significant figures is a function of the spreadsheet calculations, and not indicative of the actual accuracy of the mass or concentration values. These estimated values should generally be considered very conservative.

b. Carryover includes all potential mechanisms including volatilization, feed dust entrainment, and melt ejcction.

c. Unpublishcd documentation for Feizollahi, F. and W. J. Quapp, Integrated Thermal Treatmem

System Siudy - Phase 2 Results, INEL-95/0129, Revision 1, Fcbruary 1996.

These cstimates are qualitative estimates, presumably conservative, without considering speciation or hoiv different primary treatment systems may have somewlat different total carryover values.

e. The

c. From EPA, The Revised Standards for Hazardous Waste Incinerators, Marcle 1996, Proposed MACT Standards for New Incinerators.

g. This level includes "bulk mercury", that probably will be excluded from thermal trcatment, as is done in Feizollahi 1996. The value for mercury in the "bulk mercury" stream has been reduced from that reported in Huebner to $19,191 \mathrm{~kg}$ in subsequent ITTS and INTS studies.

h. This level excludes "bulk mercury".

i. Includes "Iead shielding" that may be excluded from thermal treatment.

j. Excludes "lead shiclding"' that may be excluded from thermal treatment.

4. Antimony was not included in the ITTS mass balances. Analyses from Soelberg 1994 show $300 \mathrm{ppm}$ antimony in a surrogate mixture of metal debris and $60 \%$ soil. 
waste that will possibly be thermally treated, calculated from the waste inventories, (c) assumed \% carryover of each metal to the offgas system, considering relative volatilities and without considering how some treatment systems and operating conditions may be able to minimize carryover of some metals, and (d) the normal and maximum offgas flowrates from Table A-4. As in Table A-4, the stack gas levels, estimated emission limits, and necessary control efficiencies were also calculated. Normal (target) stack gas concentrations of mercury, semivolatile metals, and low-volatile metals were set at only $1 / 2$ of the expected emission limits, rather than 1/10 of the limits as was done in the ITTS study. Even so, metals control efficiencies must range from 99.9 to $99.9999 \%$, higher than typical in most industrial and incineration processes. 


\section{APPENDIX B}

\section{APCS Conceptual Flowsheets}




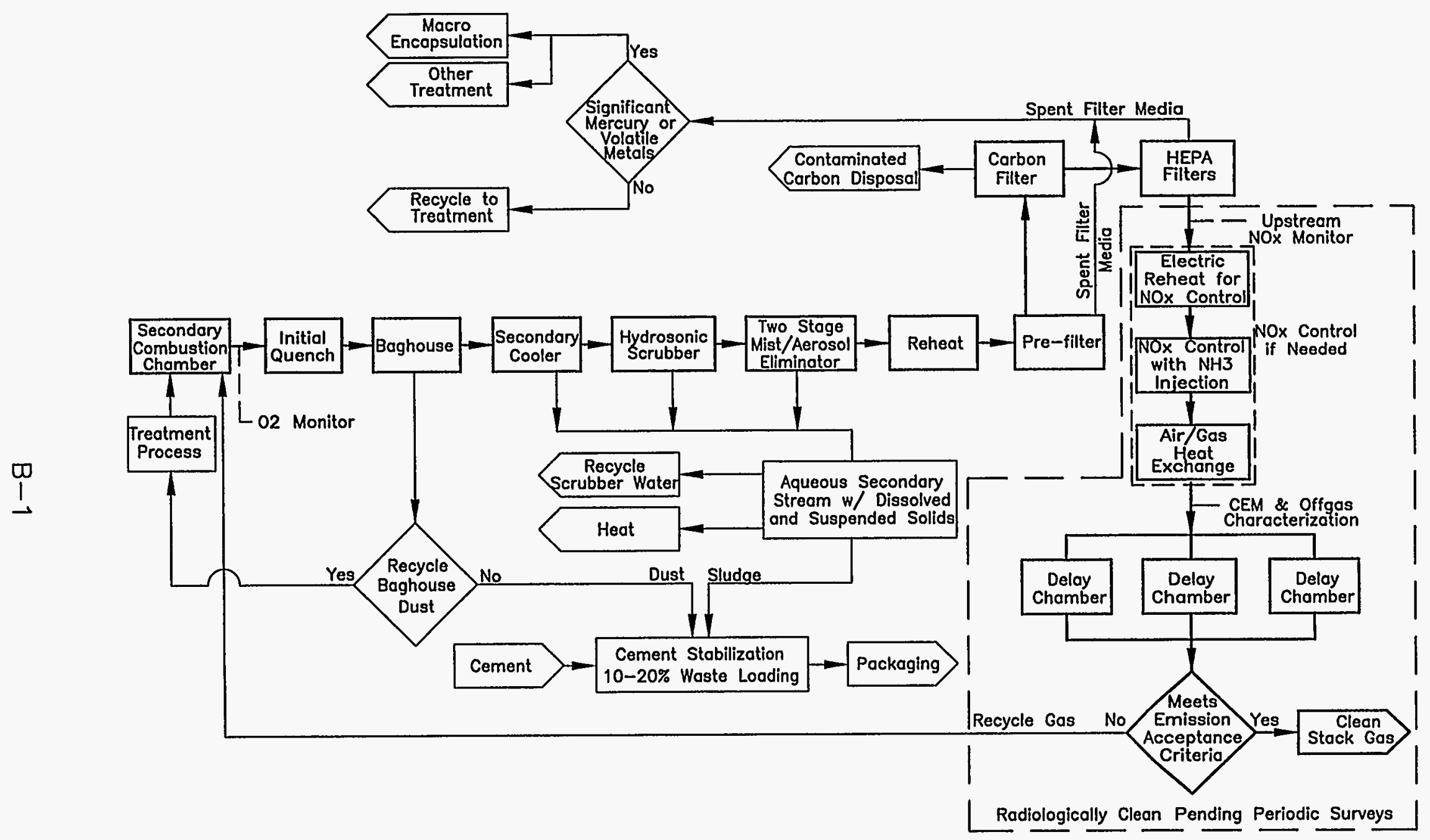

Figure $B-1$. Schematic of the $R-1$ conceptual offgas system. 


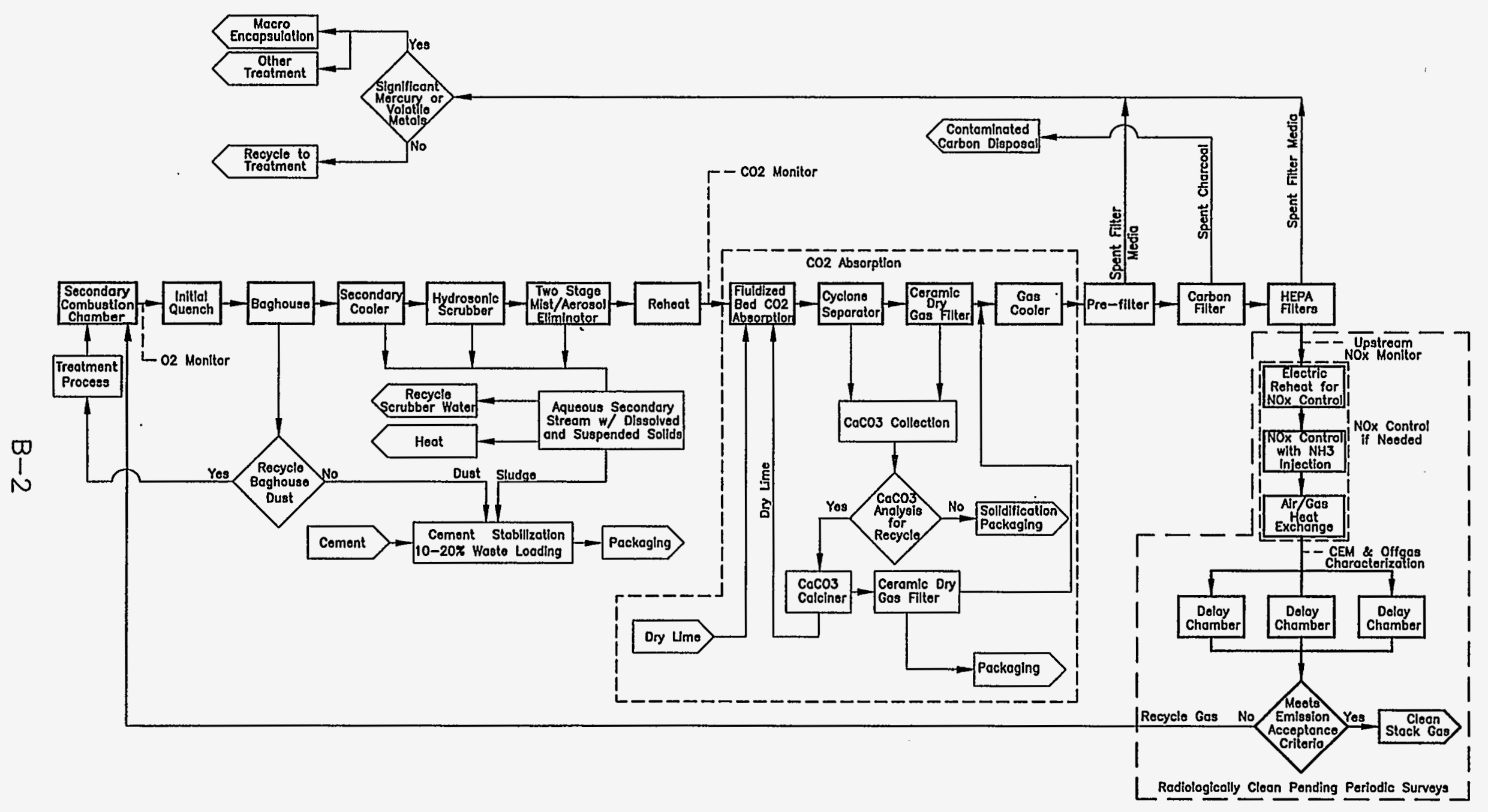

Figure B-2. Schematic of the R-2 conceptual offgas system. 


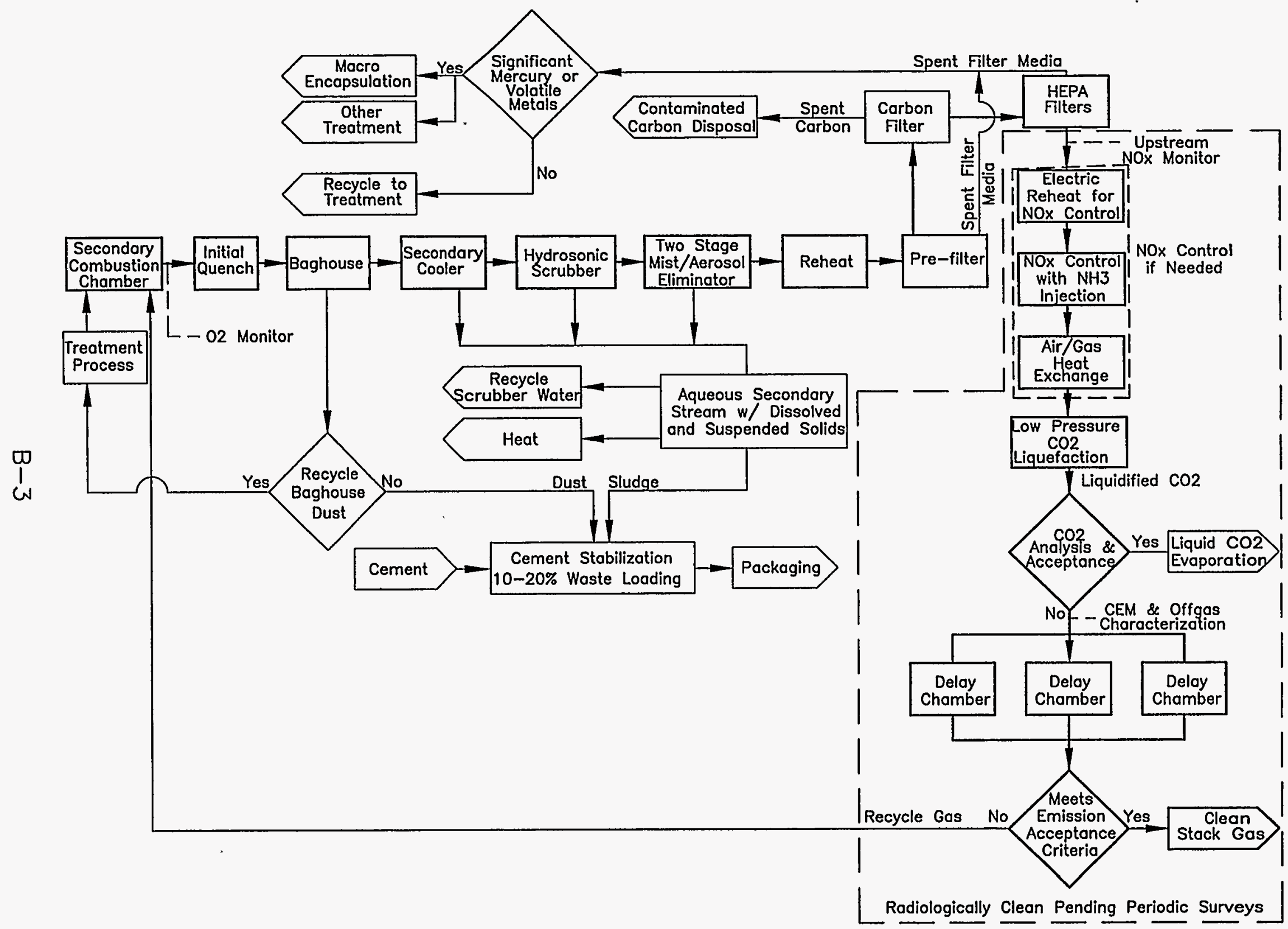

Figure $B-3$. Schematic of the $R-3$ conceptual offgas system. 


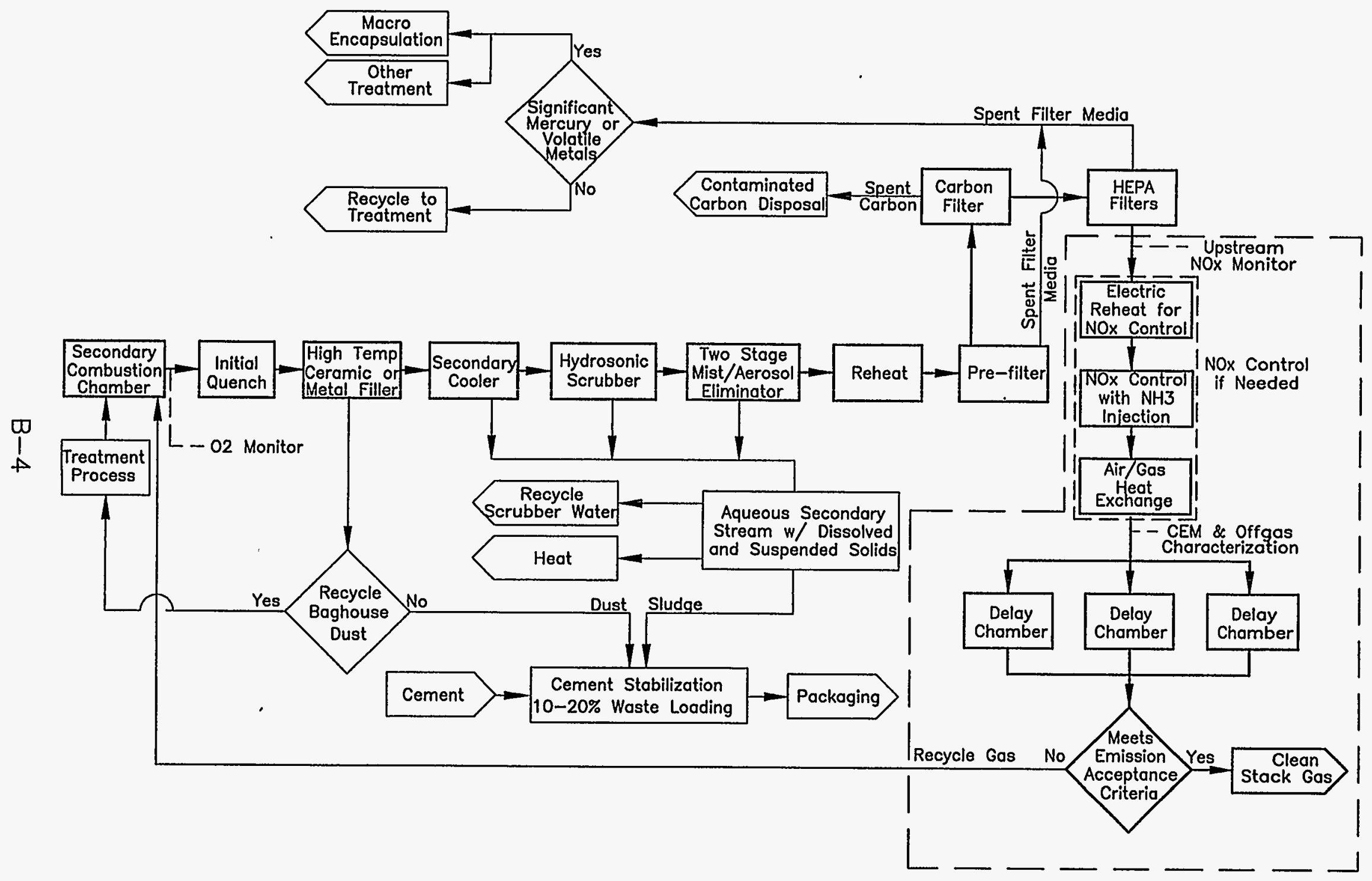

Figure B-4. Schematic of the R-4 conceptual offgas system. 


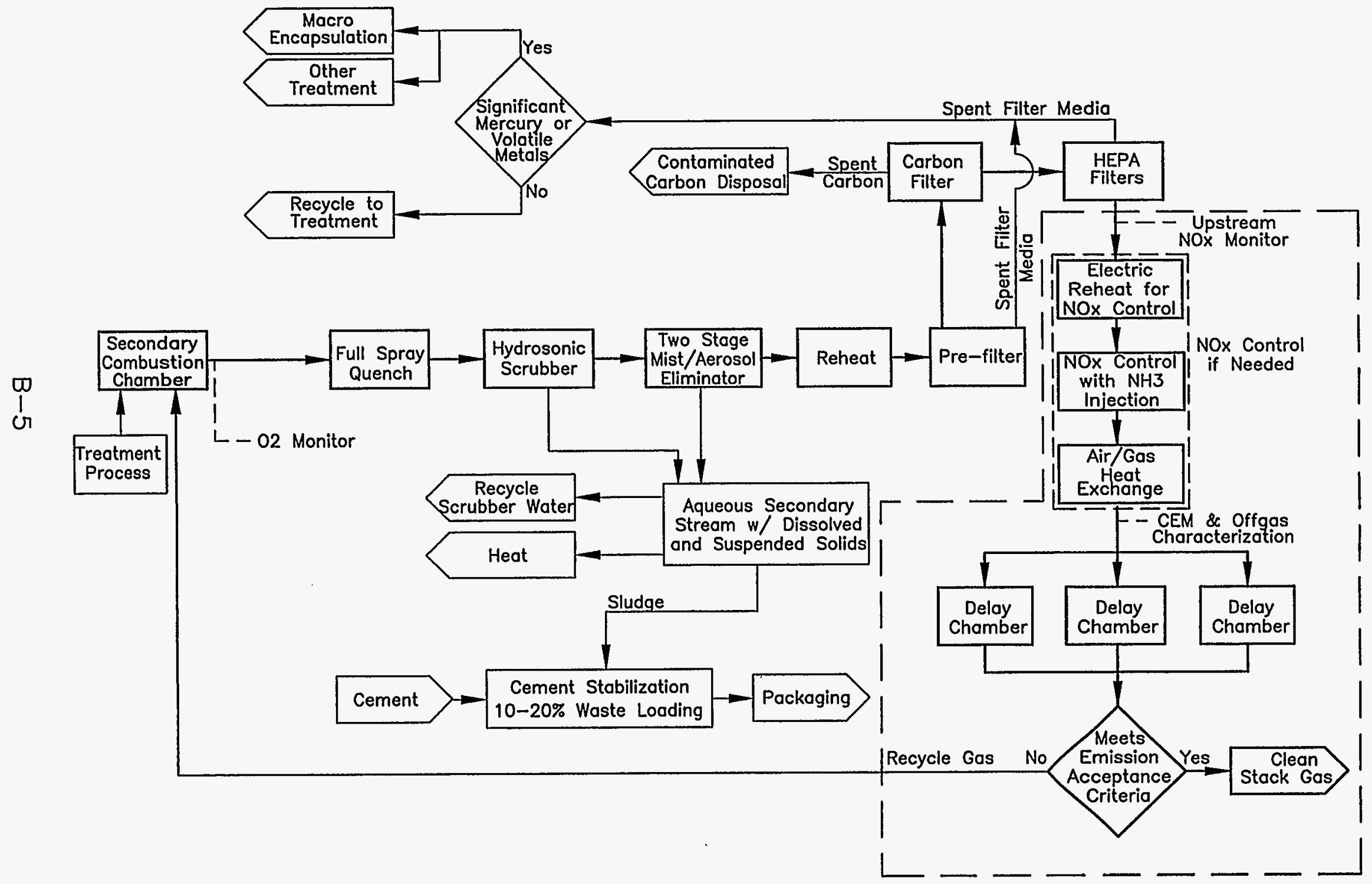

Figure B-5. Schematic of the R-5 conceptual offgas system. 


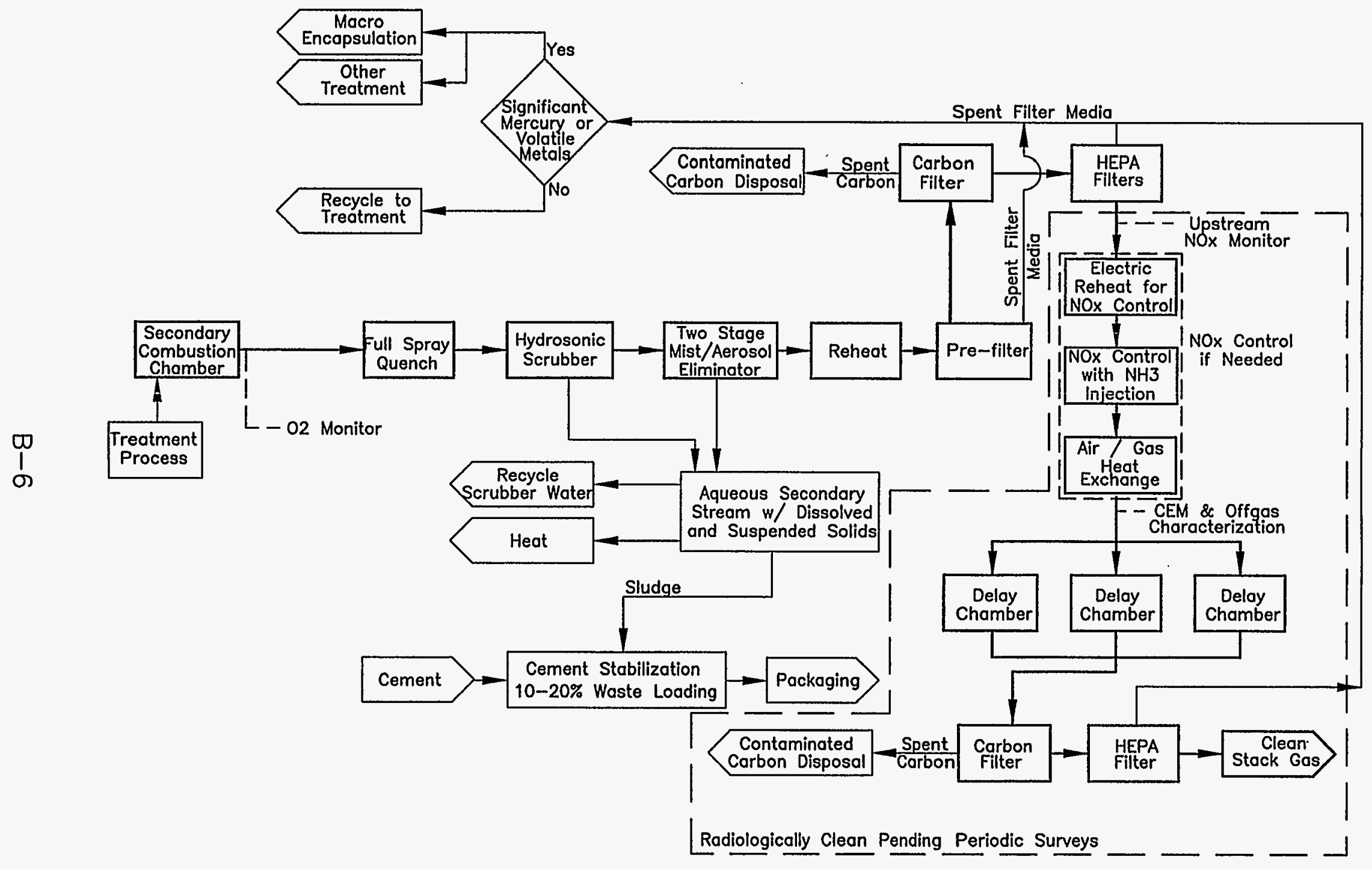

Figure B-6. Schematic of the R-6 conceptual offgas system. 


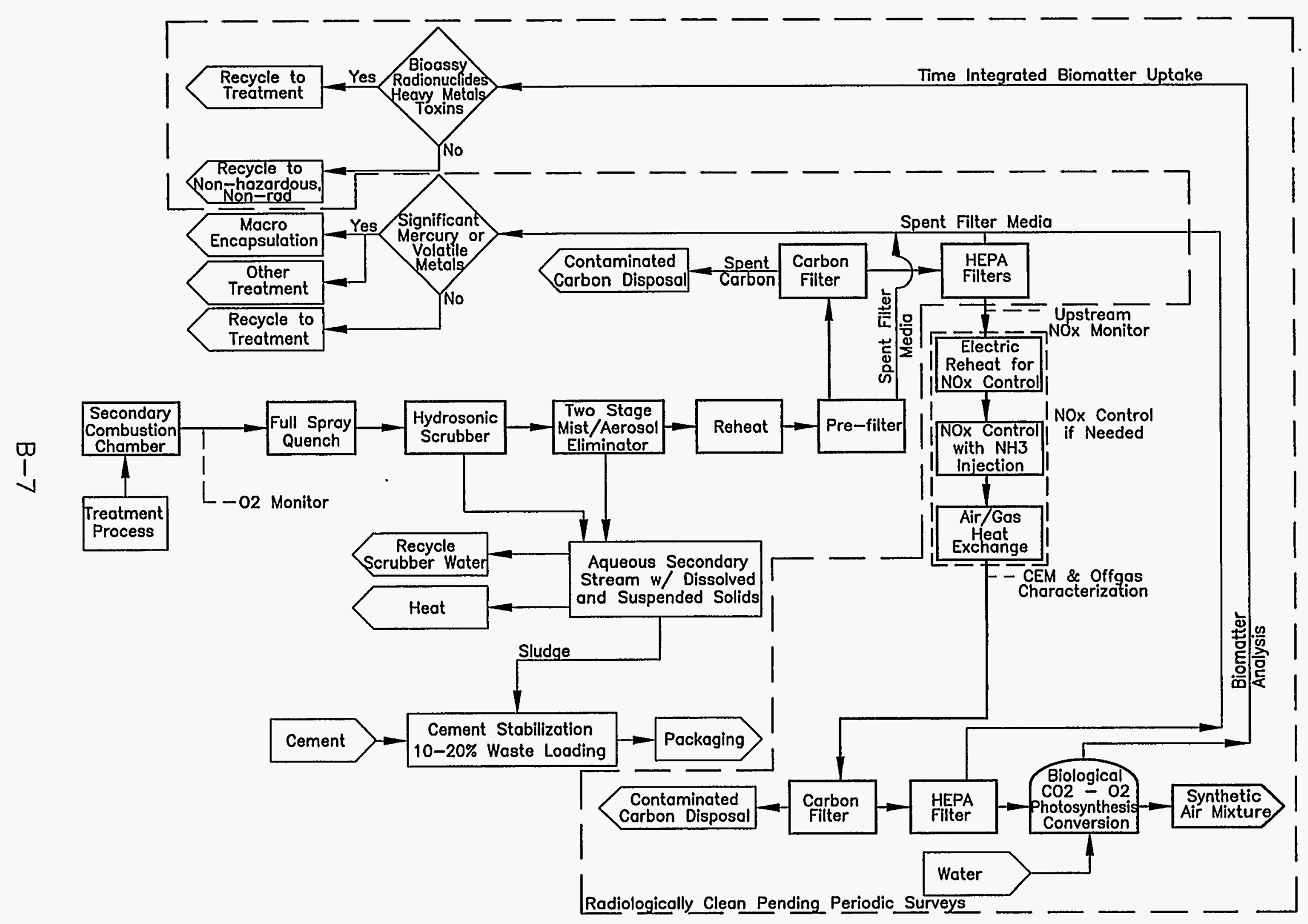

Figure B-7. Schematic of the R-7 conceptual offgas system. 


\section{APPENDIX C}

\section{Vendor Data and Calculations}

\section{Baghouse}

\section{Information from Andy Miller of BHA Group in Kansas City, August 7, 1997:}

In designing a baghouse, one of the important parameters one needs to determine is the square feet of cloth needed to clean the expected gas volume (the air-to-cloth ratio). The air-to-cloth ratio is directly related to the face velocity of the gas going into the bags such that an air-to-cloth ratio of $3: 1$ is equivalent to a face velocity of $3 \mathrm{ft} / \mathrm{min}$. Standard diameters for bags are $61 / 4^{\prime \prime}$ or $45 / 8^{\prime \prime}$ (there are also $53 / 4^{\prime \prime}$ bags as well as many other sizes). Generally, the larger the diameter, the fewer elements are required in the baghouse. Standard lengths range from $10 \mathrm{ft}$ long to $14 \mathrm{ft}$ long with a typical length being $12 \mathrm{ft}$. To determine how many bags are needed, determine the $\mathrm{cfm}$ of gas and divide it by the desired air-to-cloth ratio (which is usually determined based on experience, type of process, and size of particulate expected). This determines how many total square feet of cloth are needed in the baghouse to clean the expected gas volume. Then based on the diameter and length of the bags chosen, it is possible to figure out the total number of bags that will be required.

The pressure drop over a brand new baghouse with all clean bags inside running clean air through it with no particulate loading will typically be less than half an inch of water column pressure drop. When the baghouse is in operation, treating a particulate laden gas stream, the pressure drop will typically range from 3 to 5 inches of water. Generally, it is not desirable to operate at pressure drops higher than that. When setting up a bag cleaning schedule, it is possible to set it up to clean according to pressure drop. For example, if the normal pressure drop for efficient operation is $4 \frac{1 / 2}{2}$ " water, then cleaning can be set up to pulse the bags clean when the bags reach a pressure drop of $4 \frac{1}{2} 2^{\prime \prime}$. The bags can then be cleaned down to a pressure drop of 4 " to keep some particulate cake buildup present on the bags at all times since the particulate cake assists in the filtering process. It is desirable to keep the pressure drop cleaning window rather tight in order to keep a consistent dustcake on the bags at all times.

It is important to remember that the baghouse operates at varying pressure losses depending on the particulate buildup on the baghouse and the cleaning schedule, etc. There is typically a damper on the fan that helps adjust for variations in pressure drop across the system. For example, if the fan was designed to account for as high as $10^{\prime \prime}$ water pressure drop across the baghouse, when the bags are pulsed clean the baghouse is really operating at 4 " water and the damper has to take up the slack in the fan to insure that there is the proper draft potential available for the treatment process.

During cleaning, it is good practice to stagger the rows of bags to be cleaned. For example, first pulse row 1 , then row 4 , then row 7 , and so on. If staggering is not performed, then it is possible that row 1 will be pulsed clean and then when row 2 is pulsed clean next, the particulate that is pulsed off of row 2 will end up being immediately collected on the newly cleaned row 1. Staggering prevents this from happening. It is important to be careful to watch the header pressure before pulsing the next row and allow it to come back up to the set point before pulsing the next row. It is also important to pulse at as low a pressure as possible. In designing the baghouse, one should find the lowest pressure that will clean the bag properly and efficiently and use that for pulsing the bags. 
The can velocity is the velocity of the gas going up between the bags at the bottom of the bags. This value is calculated by determining the total air volume and dividing it by the open area of the baghouse, which is the area of the baghouse housing minus the cross-sectional area of the bags. The can velocity is the average velocity in the upwards direction. A general guideline for the maximum can velocity is 250 $\mathrm{ft} / \mathrm{min}$, however, there are baghouses that operate at $300 \mathrm{ft} / \mathrm{min}$ with no problems.

The dust resistance coefficient is not an important design parameter and is primarily a function of the resistance of the dust buildup on the bags and is calculated using the porosity of the dustcake and several other complex variables.

With baghouses, the higher the inlet loading, the greater the efficiency achieved. Efficiency equals the inlet loading minus the emissions divided by the inlet loading. Typical efficiencies for a baghouse are 99.9\% and greater for particles $0.5 \mu \mathrm{m}$ and greater. For smaller particles, it is possible to use membrane filtration on the bags in which case efficiencies of $99.99 \%$ and greater for particles $0.3 \mu \mathrm{m}$ and greater would be achieved.

The type of fabric chosen is dependent on the temperature, expected chemicals in the gas stream, and the application. In general, soil remediation work that generates soil-type particulate will require the use of a felt fabric. If clays are expected, it would likely be desirable to use a membrane filtration system; if some oil carryover is expected, some other type of bag would be used. It is all dependent on experience and what's expected in the gas stream.

The floor space required by the system will be approximately 1-3/4 to 2 times the length of the bags for determining the height of the baghouse. This will account for the hopper and clean air plenum area depending on the requirements, available space, and operational needs. The normal distance between bags is generally 1 to $1 \mathrm{1} / 2$ inches. To determine a rough estimate of the length and width of the baghouse housing, take the diameter of the bags and add an inch or so, then multiply by the number of bags in a row, then add a foot or two for a conservative estimate. For example, if there are $61 / 4$ " diameter bags, with 14 bags per row, and 1,000 bags total, the baghouse is going to be roughly $10 \mathrm{ft}$ wide by $45 \mathrm{ft}$ long.

Fourteen bags per row is about the maximum desired in a row due to air requirements for cleaning and so forth. Twelve bags per row is a typical standard, giving the baghouse housing about a $10 \mathrm{ft}$ width.

For costs, a general Rule of thumb is $\$ 5-8$ per cubic foot of air. So if the process is 50,000 acfm, it will cost about $\$ 250,000$ for the baghouse and associated accessories, including fans, etc. Operating costs are primarily dependent on the fan requirements and the compressed air used for pulsing the bags clean. Maintenance costs are fairly minimal. Bags typically last anywhere from 1 to 3 years. It is generally assumed to cost about $\$ 25$ per bag and cage assembly per year.

Calculations:

\section{Air combustion case:}

Gas flow into baghouse $=21,050$ acfm

Choose a typical air-to-cloth ratio for the process and conditions of 3:1 (which is equivalent to a face velocity of $3 \mathrm{ft} / \mathrm{min}$ ).

The square feet of cloth needed $=(21,050 \mathrm{acfm}) /(3 \mathrm{ft} / \mathrm{min})=7017 \mathrm{ft}^{2}$.

Choose a standard bag size of $6.25^{\prime \prime}$ diameter and $12^{\prime}$ long.

Surface area of bag $=\pi\left(6.25^{\prime \prime}\right)\left(144^{\prime \prime}\right)=2,827 \mathrm{in}^{2}=19.6 \mathrm{ft}^{2}$.

Number of bags needed $=\left(7017 \mathrm{ft}^{2}\right) /\left(19.6 \mathrm{ft}^{2} / \mathrm{bag}\right)=357$ bags. 
Typically have no more than 12 bags per row.

Number of rows needed $=(357 \mathrm{bags}) /(12 \mathrm{bags} / \mathrm{row})=30$ rows (cells).

Add one extra row to be offline for cleaning $=31$ rows (cells).

Cross-sectional area of bags $=\pi\left(6.25^{\prime \prime}\right)^{2} / 4=30.7 \mathrm{in}^{2}$.

372 bags $* 30.7$ in $^{2}=11,413 \mathrm{in}^{2}=79.3 \mathrm{ft}^{2}$.

Area of baghouse housing $=\left(6.25^{\prime \prime}+1.5^{\prime \prime}\right.$ spacing $) * 12$ bags $/$ row $=7.75^{\prime}=10^{\prime}$ (conservative).

$\left(6.25^{\prime \prime}+1.5^{\prime \prime}\right.$ spacing) $* 31$ rows of bags $=20^{\prime}=22$ (conservative).

$10 \mathrm{ft} * 22 \mathrm{ft}=220 \mathrm{ft}^{2}$.

Open area $=220 \mathrm{ft}^{2}-79.3 \mathrm{ft}^{2}=141 \mathrm{ft}^{2}$.

Can velocity $=(21,050 \mathrm{acfm}) /\left(141 \mathrm{ft}^{2}\right)=149.6 \mathrm{ft} / \mathrm{min}$.

Typical Rule-of-thumb costs are $\$ 5-8$ per cubic foot of air. Conservative cost estimates are, therefore, $\$ 8 *$ 21,050 acfm $=\$ 168,400$.

\section{O2-combustion case:}

Gas flow into baghouse $=11,800 \mathrm{acfm}$

Choose a typical air-to-cloth ratio for the process and conditions of $3: 1$ (which is equivalent to a face

velocity of $3 \mathrm{ft} / \mathrm{min}$ ).

The square feet of cloth needed $=(11,800 \mathrm{acfm}) /(3 \mathrm{ft} / \mathrm{min})=3933 \mathrm{ft}^{2}$.

Choose a standard bag size of $6.25^{\prime \prime}$ diameter and $12^{\prime}$ long.

Surface area of bag $=\pi\left(6.25^{\prime \prime}\right)\left(144^{\prime \prime}\right)=2,827 \mathrm{in}^{2}=19.6 \mathrm{ft}^{2}$.

Number of bags needed $=\left(3933 \mathrm{ft}^{2}\right) /\left(19.6 \mathrm{ft}^{2} /\right.$ bag $)=200$ bags.

Typically have no more than 12 bags per row.

Number of rows needed $=(200$ bags $) /(12$ bags/row $)=17$ rows (cells).

Add one extra row to be offline for cleaning $=18$ rows (cells).

Cross-sectional area of bags $=\pi\left(6.25^{\prime \prime}\right)^{2} / 4=30.7 \mathrm{in}^{2}$.

216 bags $* 30.7 \mathrm{in}^{2}=6,627 \mathrm{in}^{2}=46 \mathrm{ft}^{2}$.

Area of baghouse housing $=\left(6.25^{\prime \prime}+1.5^{\prime \prime}\right.$ spacing $) * 12$ bags/row $=7.75^{\prime}=10^{\prime}$ (conservative).

$\left(6.25^{\prime \prime}+1.5^{\prime \prime}\right.$ spacing) $* 18$ rows of bags $=12^{\prime}=15^{\prime}$ (conservative).

$10 \mathrm{ft} * 15 \mathrm{ft}=150 \mathrm{ft}^{2}$.

Open area $=150 \mathrm{ft}^{2}-46 \mathrm{ft}^{2}=104 \mathrm{ft}^{2}$.

Can velocity $=(11,800 \mathrm{acfm}) /\left(104 \mathrm{ft}^{2}\right)=113.5 \mathrm{ft} / \mathrm{min}$

Typical Rule-of-thumb costs are $\$ 5-8$ per cubic foot of air. Conservative cost estimates are, therefore, $\$ 8 *$ 11,800 acfm $=\$ 94,400$.

\section{Free-jet Scrubber}

Information from O. L. Holland of Hydro-Sonic Systems in Linden, Texas, August 13, 1997:

The ratio of scrubbing water to gas to be scrubbed is typically about $0.5 \mathrm{lb} \mathrm{H}_{2} \mathrm{O} / \mathrm{lb}$ gas. Savannah River has used all the way up to $1 \mathrm{lb} \mathrm{H}_{2} \mathrm{O} / \mathrm{lb}$ gas to get cleaning all the way down to 0.0001 . There is a point of diminishing returns after going any higher than $1 \mathrm{lb} \mathrm{H}_{2} \mathrm{O} / \mathrm{lb}$ gas. The ratio of atomizing steam to gas is typically in the range of 0.15 to $0.25 \mathrm{lb}$ steam / lb gas (at $50 \mathrm{psi}$ ). Atomizing air is generally double the 
ratio of atomizing steam because of the density difference (also at $50 \mathrm{psi}$ ). Typical values are $0.3 \mathrm{lb}$ air $/ \mathrm{lb}$ gas or $0.15-0.20 \mathrm{lb}$ steam/lb gas. The difference between air and steam is $1.65 \mathrm{lb}$ air: $1 \mathrm{lb}$ steam. The advantage of steam over air is that it immediately condenses and doesn't add to the fan burden.

After the system has been designed to handle a typical gas flow, the inlet particulate loading has little effect on the particulate removal efficiency desired. The system achieves the efficiency that is desired simply by adjusting the amount of atomizing steam or air to achieve the desired outlet particulate concentration. Increasing the flowrate of the atomizing gas increases the particulate removal efficiency of the process by increasing the available surface area of the atomized liquid. Particulate matter agglomerates onto the surface of the liquid droplets and are removed from the offgas. The water droplet size should be no more than 10 times bigger than the particle size that it is desired to capture. If the droplets are more than about 10 times bigger, the particles are likely to just go right around them because of the surface tension. If the process has a vast number of very small particles, say $90 \%<0.05 \mu \mathrm{m}$ at $1000 \mathrm{lb} / \mathrm{min}$, it is going to require significantly more power to achieve good efficiencies in order to atomize the water droplets to that fine of a level. Particle removal overall efficiencies are as high as $99+\%$ depending on the particulate particle size. Wettability of the particle also influences the energy required. It is more desirable to deal in grains per standard cubic feet emission requirements as it is an absolute number. An example is tests conducted on a Hazardous Waste Incinerator where the inlet grain loading was varied from 2 grains to 10 grains. The outlet emissions were the same, around $0.005 \mathrm{gr} / \mathrm{scf}$ in both cases but from an efficiency standpoint the tests with 10 grains inlet was much higher than that with $2 \mathrm{gr} / \mathrm{scf}$.

Removal of $95 \%$ on particles as small as $0.05 \mu \mathrm{m}$ has been catalogued. For acid gas removal, if the system uses $\mathrm{NaOH}$ and the $\mathrm{pH}$ is kept at about 7, virtually all acid gases will be removed. It is possible to achieve $99.99 \%$ removal for $\mathrm{SO}_{2}$ and nearly complete $\mathrm{HCl}$ removal can be obtained. The $\mathrm{SO}_{2}$ reaction with $\mathrm{NaOH} /$ water solution is a liquid phase reaction. $\mathrm{SO}_{2}$ gas is absorbed by the solution to form liquid containing $\mathrm{Na}_{2} \mathrm{SO}_{3}$ and/or $\mathrm{NaHSO}_{3}$ depending on the bottoms $\mathrm{pH}$. The liquid is separated in a liquid/gas separator so there is no carryover with the scrubbed gas.

There are virtually no temperature limits on the scrubber system. Hydro-Sonic Systems have designed and operated scrubbers that function up to about $2,200^{\circ} \mathrm{F}$, in which case they would build the unit out of Hastelloy, all the way to systems that operate below $200^{\circ} \mathrm{F}$, in which case they can use a fiberglass material.

The gas velocity entering the mixing tube should be below $200 \mathrm{ft} / \mathrm{s}$. For a steam driven system, the velocity can be anywhere from 0 to $200 \mathrm{ft} / \mathrm{s}$. The system is fairly insensitive to turndown and there is no effect on the system operation at lower gas velocities. It is common practice to size a system to $120 \%$ of what is required and because of the infinite turndown it has no problem operating at levels lower than the design values.

For the steam driven system, there is usually a pressure rise instead of a pressure drop. If it is undesirable for the system to go positive, the system can be sized differently to use the damper on the fan to hold the pressure at neutral at the exit of the scrubber. It is possible to use the fan to keep the pressure between $0.5^{\prime \prime}$ and $0^{\prime \prime} \mathrm{H}_{2} \mathrm{O}$ and avoid going positive in the system.

The cost of equipment for 4 cases were considered. 
Case 1: Rotary kiln incinerator using air combustion with offgas at $7000 \mathrm{scfm}$ cleaning to $0.03 \mathrm{gr} / \mathrm{dscf}$ will require a Hydro-Sonic Model 1250 Air Hydro Scrubber.

Case 2: Melter using oxygen combustion with offgas at $3500 \mathrm{scfm}$ cleaning to $0.03 \mathrm{gr} / \mathrm{dscf}$ will require a Model 600.

Because of the large amount of compressed air that must be added to decrease the outlet emissions to $0.0009 \mathrm{gr} / \mathrm{dscf}$, a larger unit size is needed to handle the gas plus the added compressed air.

Case 3: Rotary kiln incinerator using air combustion with offgas at $7000 \mathrm{scfm}$ cleaning to $0.0009 \mathrm{gr} / \mathrm{dscf}$ will require a Model 1500 .

Case 4: Melter using oxygen combustion with offgas at $3500 \mathrm{scfm}$ cleaning to $0.0009 \mathrm{gr} / \mathrm{dscf}$ will require a Model 800.

The scrubber unit will consist of the following components:

$\begin{array}{lll}1 & \text { FRP } & \text { Ejector mounting section } \\ 1 & \text { C276 } & \text { Air injector/water injector assembly } \\ 1 & \text { FRP } & \text { Plenum/Mixing tube assembly } \\ 1 & \text { FRP } & \text { Cyclone separator assembly } \\ 1 & \text { lot } & \text { nuts, bolts, water nozzles, and other miscellaneous parts } \\ 3 & \text { copies } & \text { Assembly, process flow, and instrumentation drawings } \\ 3 & \text { copies } & \text { Operations, installation, and maintenance manual. }\end{array}$

The high-flow case will have a particle size distribution of $40 \%<0.5 \mu \mathrm{m}, 60 \%>0.5 \mu \mathrm{m}$. The Low-flow case will have a particle size distribution of $60 \%<0.5 \mu \mathrm{m}, 40 \%>0.5 \mu \mathrm{m}$.

For the high-flow case, there will be $48,200 \mathrm{lb} / \mathrm{hr}$ of gas entering the scrubber. For the Low-flow case, there will be $25,800 \mathrm{lb} / \mathrm{hr}$ of gas entering the scrubber. That gas stream contains approximately 58 mass $\%$ water.

The budget price for case 1 is $\$ 145,000$; case 2 is $\$ 105,000$; case 3 is $\$ 160,000$; and case 4 is $\$ 117,000$. Prices are FOB point of manufacture.

The Steam/Air Hydro is a wet scrubbing system in which the energy for cleaning and pumping of polluted gases is provided by the flow of a compressible fluid from a supersonic ejector nozzle. Steam or compressed air at $30 \mathrm{psig}$ (minimum) is commonly used as the driving fluid. It is estimated that at least 0.2 $\mathrm{lb}$ of $100 \mathrm{psig}$ air per pound of gas is required to scrub to $0.03 \mathrm{gr} / \mathrm{dscf}$ and about 0.68 pounds of compressed air per pound of gas is required to scrub to $0.0009 \mathrm{gr} / \mathrm{dscf}$. That is the reason for the increase in model size for the higher scrubbing efficiency. The water or scrub liquid requirement is $60 \mathrm{gpm}$ for case 1 and 3 and 30 gpm for case 2 and 4, at a pressure of 30 psig at the scrubber manifold.

There will need to be a downstream fan to pull about 4 " water negative pressure on the cyclone outlet in order to keep the total system under negative pressure. There must be a damper control valve between the scrubber and the furnace to regulate the furnace draft.

If an Air Ejector drive is used the unit would be sized with the added gas taken into consideration. The gas flowrate will increase very little. 
A high scrubbing efficiency can be maintained with a $\mathrm{pH}$ as low as 6.5. As the $\mathrm{pH}$ drops lower than this, efficiency will fall off somewhat. Other acid gases such as $\mathrm{HCl}$ are more easily scrubbed as the $\mathrm{pH}$ increases above 7.

The operation and performance of the scrubber will be designed with turndown if required. The ejector scrubbers aren't sensitive to turndown but due to having a fixed orifice throat, the Fan drives will require either a recycle duct from the exhaust stack to the scrubber inlet or a variable nozzle unit could be built to maintain a constant delta $P$ across the scrubber.

In a brochure provided by Hydro-Sonic Systems there is a page showing various graphs and one of these plots emissions (gr/scf) versus lbs steam/lb gas cleaned. On this graph the slopes of the lines for the various processes are all very similar except for the hazardous waste incineration process. The absolute outlet emission is almost independent of inlet dust load because the atomizing gas can be adjusted to achieve a specific result. The only time that it becomes dependent upon inlet dust load is when the inlet dust load is very low (say $<5$ times the outlet allowable). When this happens, the curve begins to flatten out, which is what happened in this case. Normally all processes have the same emission/energy slope, including hazardous waste processes. The modeling takes low dust load cases into account when predicting energy requirements.

$\mathrm{SO}_{2}$ removal efficiency is dependent almost totally upon the ratio of $\mathrm{SO}_{2}$ to reagent addition. The scrubber scrubs $\mathrm{SO}_{2}$ to almost $100 \%$ theoretical stoichiometric values, for both the sulfite and bisulfite reactions. Air and steam give essentially the same efficiency based on equivalent molecular weights of each input. That is, it takes $M_{\text {air }} / M_{\text {steam }}$ more air than steam to scrub to the same level. The only notable difference is that much of the steam condenses out, while the air does not, and that is the reason for recommending larger units for higher efficiency.

\section{Prefilter}

Information from Wilford W. Stagg of Midgley-Huber, a representative of Flanders Filter, on August 20, 1997.

For the prefilter, it is preferred to use the Airpure Rigid Pak 95 in a $24 " \times 24 " \times 6 "$ size.

Generally, Flanders see $25-30 \%$ or $60-65 \%$ ASHRAE filters used as prefilters. The filter specified above has $90-95 \%$ efficiency with $99 \%$ average arrestance and $29 \mathrm{ft}^{2}$ of media area.

\section{HEPA}

Information from Wilford W. Stagg of Midgley-Huber, a representative of Flanders Filter, on August 20, 1997.

We are modeling a system where the gas flow will be about 22,500 acfm when it enters the HEPA train so we will need two $4 \times 3$ units in parallel to handle the gas flow.

If $\mathrm{HNO}_{3}$ is expected to be present in the airstream, the filters should be treated for resistance to $\mathrm{HNO}_{3}$. However, depending on the concentration, the airstream may need to be treated or diluted before it contacts the HEPA filters. 
It is possible to replace the first test outlet and the second test inlet with a test combination, model TSC4H3W-GG-304-D1. In doing so, individual filter testing capability of at least one bank is eliminated. It is recommended that the test combination be located between the carbon banks to allow for overall testing of each HEPA bank and each carbon bank.

By definition, HEPA filters must be at least $99.97 \%$ efficient on $0.3 \mu \mathrm{m}$ size particles. All HEPA filters are factory tested to ensure this efficiency and factory test reports are available and should be requested. A clean HEPA filter which exhibits $99.97 \%$ efficiency will only become more efficient as it loads with particulate. Certainly the second HEPA filter will see significantly less particulate, but it is still a HEPA filter and therefore must be at least $99.97 \%$ efficient.

In ASME N509-1989, decontamination factor is defined as "the ratio of the concentration of a contaminant in the uncleaned (untreated) air to its concentration in the clean (treated) air". The decontamination factor can be obtained by calculating the reciprocal of the filter's penetration expressed as a fraction. For example, a $99.97 \%$ efficient HEPA filter has a penetration of $0.03 \%$, therefore, $1 / 0.0003=3,333$ decontamination factor.

The standard equipment offered by Flanders/CSC is constructed of T-304 stainless steel. This type of stainless was chosen as the base material because it is readily available, reasonably priced, and will satisfy most project requirements. There are lower and higher grades of material that may be used as dictated by the project requirements.

A faceguard is a wire mesh protective screen attached to the HEPA filter element's upstream and/or downstream face. To meet MIL-F-51068, a 24"x24" HEPA filter is required to have faceguards on both the upstream and downstream faces.

Filter life can not be determined based on the given information. Typically, differential pressure indicators are installed across the filter banks. When the differential pressure reaches a predetermined point, it is time for filter replacement. The Rule of thumb is that clean standard capacity HEPA filters are rated at 1" water gage pressure drop at $1,000 \mathrm{cfm}$ air flow. Typically, HEPA filters are designed to withstand a maximum pressure drop of $10^{\prime \prime}$ water gage before failure but it is recommended they not be used to that extent. Usually filters are changed when they reach 3 " to 5 " water gage pressure drop.

Specific process upsets would have to be specified. The filter unit can withstand, to some extent, air flow or pressure surges.

\section{Carbon bed for mercury adsorption}

Information from Wilford W. Stagg of Midgley-Huber, a representative of Flanders Filter, on August 20, 1997.

Mercury removal with charcoal requires a specially impregnated carbon and a very long air to carbon bed contact time. Carbon adsorbers should not be used for particulate removal. The system should be configured to protect carbon adsorbers from particulate by incorporating a prefilter and/or HEPA filter upstream. Mercury is difficult to remove and requires a sulfur-impregnated carbon for removal. Several vendors suggested that the carbon media would have a $20 \mathrm{wt} \%$ loading capacity for mercury. 
Information from Calgon Carbon Corporation indicated that temperatures in the carbon beds should not exceed $158^{\circ} \mathrm{F}$. At temperatures higher than this, the impregnate may volatilize and be driven into the offgas, possibly requiring the use of a scrubber or other acid gas removal device downstream of the carbon beds. At temperatures close to $200^{\circ} \mathrm{F}$, approximately $1 \mathrm{lb}$ of sulfur will be removed from the carbon bed per day, resulting in a decrease in the carbon impregnation of about $4.8 \mathrm{wt} \%$ over a period of one year. Because of this phenomenon, the removal efficiency of mercury on the carbon beds will be decreased at temperatures higher than $158^{\circ} \mathrm{F}$. The sulfur-impregnated carbon will have some potential for removal of organics. Organic compounds most likely to be adsorbed on the carbon are those with high molecular weights and vapor pressures. These compounds will likely see a $99 \%$ removal. For weaker adsorbing organic compounds such as methane and propylene, the removal will be in the range of $25-99 \%$. Iodine impregnates will likely behave in a similar manner.

This and other vendors have suggested that spent impregnated carbon from a bed system can be thermally generated using the same type of equipment used in a retort-condenser process. There are not any commercial facilities to regenerate radioactively contaminated carbon, although one vendor suggested the regeneration equipment could be bought and the regeneration performed at the offgas facility.

Impregnated carbons will have little or no effect on removing dioxins and furans (D/F). However, plain activated carbon has been demonstrated to effectively remove $D / F$ from a gas stream with various efficiencies being reported throughout the literature. Most vendors recommend using a separate bed of virgin activated carbon for removal of dioxins before a second bed designed for mercury removal. Other options include preparing a single bed with a mixture of impregnated and virgin carbons whose capture cross sections will be adequate for both gases.

\section{Final HEPA}

Information from Wilford W. Stagg of Midgley-Huber, a representative of Flanders Filter, on August 20, 1997.

New model numbers are as follows:

$\begin{array}{ll}\text {-HEPA filter: } & \text { T-010-W-03-05-NU-51-23-GG-FU5 } \\ \text {-Adsorber: } & \text { AF-GG16-62-NS } \\ \text {-Pre/test inlet hsg: } & \text { TSI-4H3W-6GG-304-D1 } \\ \text {-HEPA hsg: } & \text { BF1-4H3W-GGF-304-D1 (both stages) } \\ \text {-Test outlet hsg: } & \text { TSO-4H3W-GG-304-D1 (both stages) } \\ \text {-Carbon hsg: } & \text { BF1-4H3W-GG16-304-D1 (both stages) } \\ \text {-Test inlet hsg: } & \text { TSI-4H3W-GG-304-D1 }\end{array}$

The sequence of equipment shown will work fine for in-place testing of the HEPA filters. It allows for inplace leak testing of each individual HEPA filter in each bank. In other words, a single leaking filter in either bank of twelve filters can be easily located. In the absence of the test sections, a single leaking filter could not be located without first removing all filters from the filter housing and individually testing them outside the housing. 
To make the system even more in-place testable, it is recommended to change both test inlet housings (located downstream of first HEPA and upstream of second HEPA) to test combinations AND add a test combination between the carbon banks. This arrangement will allow in-place testing of each individual HEPA filter and each individual carbon adsorber. The current arrangement requires that both carbon banks be tested together at one time, thus they must be considered one bank.

Require 2 nominal 12,000 cfm bag-in/bag-out filter system including:

- $\quad$ Model TSI-4H3W-6GG-304-D1 prefilter/inlet test section

- $\quad$ Model BF1-4H3W-GGF-304-D1 HEPA housing

- $\quad$ Model BF1-4H3W-GG16-304-D1 carbon housing

- $\quad$ Model BF1-4H3W-GG16-304-D1 carbon housing

- $\quad$ Model TSC-4H3W-GG-304-D1 combination test section

- $\quad$ Model BF1-4H3W-GG16-304-D1 carbon housing

- Model BF1-4H3W-GGF-304-D1 carbon housing

- $\quad$ Model BF1-4H3W-GGF-304-D1 HEPA housing

- $\quad$ Model TSO-4H3W-GG-304-D1 outlet test section

- Welding in series

- $\quad 6$ " system base

- $\quad$ Static pressure taps

- (4) installed Magnehelic gages

- Test ports

- Weathercaps

- $\quad$ Lifting lugs

- Swivel access door latches

- (12) $95 \%$ ASHRAE prefilters

- (24) $99.97 \%$ mil-spec HEPA filters

- (48) Model AF-GG16-62-*S(SP) carbon adsorbers for mercury removal

Unit price of $\$ 286,400$. Total price of $\$ 572,800$. There is sufficient moneys in this estimate for some seismic bracing and documentation in case it is required. This price includes an initial set of filters.

\section{$\mathrm{NO}_{\mathrm{x}}$ Control}

\section{Information from Gary Bernstein of Babcock \& Wilcox in Portland, September 15, 1997 :}

SCR equipment used by the boiler industry typically operates at temperatures of $350-450^{\circ} \mathrm{F}$. SCRs can often reduce $\mathrm{NO}_{\mathrm{x}}$ levels to $9 \mathrm{ppm}$ to meet some stringent limits. For removal efficiencies, a gas turbine typically puts out $300-400 \mathrm{ppm} \mathrm{NO} \mathrm{N}_{x}$ and it is possible to reduce it down to $9 \mathrm{ppm}$ (roughly $98 \%$ removal).

As far as excess ammonia is concerned, ammonia slip is not that big of a problem and in general it is not necessary to have any scrubbers or other collection equipment downstream of the SCR in order to catch excess ammonia.

The catalyst is purchased from Hitachi. It is a plate-type catalyst where the catalyst is baked onto the plates. The catalyst is titanium based. The catalyst has a fairly long life and if processing clean gas only it will likely last 5 or more years. Catalyst replacement will depend primarily on the gas stream constituents and potential poisons of which the primary ones are excessive moisture and certain heavy metals. 
Temperature is of course an issue too on the catalyst life but if the temperature remains within the design constraints of the system it should not be a problem.

For a gas flow of $78,250 \mathrm{lb} / \mathrm{h}$, the capital costs will run approximately $\$ 500,000$ and will include the SCR system, the catalyst, the flue work, and the ammonia injection skid. For a gas flow of $39,125 \mathrm{lb} / \mathrm{hr}$, the capital costs will be roughly $\$ 400,000$. The operating costs will consist primarily of the purchase of ammonia.

Information from CSM Environmental Systems, Inc. from NWCF study: The $\mathrm{NO}_{\mathrm{x}}$ removal step requires the upstream injection of ammonia into the offgas followed by intimate mixing before introduction into the SCR bed. The amount of ammonia added exceeds the stoichiometric amount by a safety factor based upon experience to insure the complete (about $99 \%$ ) conversion of $\mathrm{NO}_{x}$ to $\mathrm{N}_{2}$. Typically about 1.1 to 1.2 moles of ammonia are added per mole of $\mathrm{NO}_{\mathrm{x}}$ to be converted. The temperature into the SCR bed is very critical and is controlled at about $750^{\circ} \mathrm{F}$ via an upstream burner.

The fuel costs for operation of catalyst systems is much less than for direct fired combustion processes. Since the offgas treatment system will be located downstream of existing HEPA filters the main source of catalyst poisoning, which is particulates, will be reduced. The formation of ammonium sulfite in the SCR could be a source of catalyst poisoning for both catalyst beds.

\section{Quench Towers}

Information from Ralph Koenig of Merlin Co./Boulder, Inc., September 25, 1997.

The materials of construction for the units quoted are carbon steel with an internal lining of tough, acidresistant, baked-on polymer. This method of construction is very strong and is appropriate for an evaporative cooler, which runs dry, and for the full quencher, which in this case has a cool offgas inlet temperature. Also at the rather mild full-quench inlet conditions, a jet-ejector type of saturator can be specified which is much less expensive than a wetted-wall quencher. If it was necessary to cool to saturation in the first unit following the SCC, it would be recommended to use Hastelloy C-22 or C-276 which is much more expensive. The top section of the evaporative cooler is refractory-lined.

Budget costs for the partial and full quench tower for the high-flow case are $\$ 251,000 \pm 25 \%$ and $\$ 44,000$ $\pm 25 \%$, respectively. For the Low-flow case, costs for the partial and full quench tower are $\$ 186,000 \pm 25 \%$ and $\$ 32,000 \pm 25 \%$, respectively.

The vessels are welded inside and out. The price includes refractory installation, interior coating, exterior painting, gaskets and fasteners, spray nozzles (regular and emergency), spray manifolds, thermocouples, control valves, and other controls specific to proper function. The price does not include support structures or external insulation (required at the base of the evaporative cooler).

\section{Retention Tanks}

Figure 14-56 from Peters and Timmerhaus provided costs for mixing, storage, and pressure tanks. Using this graph, the January 1990 cost of a 100,000 gal 30-psig carbon steel spherical tank was estimated to be $\$ 190,000$. The January 1990 Marshall \& Swift Process-industry cost index was 924 as found in Peters and Timmerhaus, Table 3 on p. 163. From the August 1997 edition of Chemical Engineering, p. 166, the 
Marshall \& Swift Process-industry average cost index for the second quarter of 1997 was listed as 1066.8. Using a formula found in Peters and Timmerhaus p. 164, the present cost of a 100,000 gal carbon steel spherical tank was calculated to be $\$ 219,364$. Next, a capacity-ratio exponent formula from Perry's, p. 25 65 was used to scale the cost for a 132,086,026 gal tank. This method, using data for pressure vessels, gave the cost of one tank as $\$ 18,884,083$. For three such tanks, the cost will be $\$ 56,652,249$. The cost for the tank needed in the Low-flow case was calculated the same way as previously described resulting in the cost for one tank as $\$ 8,951,815$, and for three tanks, a total cost of $\$ 26,855,445$. A vacuum pump capable of evacuating the tanks for the high-flow case will require roughly $800 \mathrm{hp}$ at $18,000 \mathrm{cfm}$. The Low-flow case will require a $250 \mathrm{hp}$ vacuum pump to evacuate the tank at $5,500 \mathrm{cfm}$. Using similar cost scaling factors for size, capacity, and time, the pumps for the high-flow case were calculated to be in the range of $\$ 500,000$ to $\$ 1,050,000$. For the Low-flow case, the range was determined to be $\$ 300,000$ to $\$ 750,000$. These numbers were derived by assuming that the type of pump to be used would be reciprocating pumps. One pump is all that would be needed for evacuating the tanks, however, in the capital cost estimate, the cost of two pumps was factored in to include a spare pump as a backup in case the first pump failed.

A range of costs was calculated for the retention tanks to include the uncertainty of engineering and design of such massive structures. It is uncertain whether the tanks would need to be housed inside of a structure. If the tanks were to simply sit outside on a concrete pad, there may be need to provide special weatherization to protect against changes in temperature from one season to another. There may also be need to provide heating of the tanks to prevent condensation of the offgas from occurring. If housing for the tanks is needed, a cost factor of $\$ 420 / \mathrm{ft}^{2}$ was used. It is not known what level of containment would be necessary, if any, for the retention tanks.

Such a large tank system would be an engineering feat to design and build. It would need to be spherical in shape to prevent it from collapsing in on itself during evacuation. The structural supports and bracing that would be required would require much time and money. Since the costs for the tanks alone far exceeds the cost of the entire air pollution control system, it seems ludicrous to pursue such an option.

The retention tank option that was modeled for this study represents the worst case based on the assumption that the entire offgas volume would need to be retained. Other options available include removing the carbon dioxide from the offgas prior to retention, which would decrease the volume of the offgas by as much as $40 \%$. The water present in the offgas could also be condensed out of the stream reducing the offgas volume even more. It is possible that using a variety of options, the offgas volume could be reduced by as much as a factor of ten which would decrease the size of the retention tanks needed to retain the offgas and thereby reduce the associated costs.

\section{Process Instrumentation and Automatic Waste Feed Cutoff System}

Technical details regarding equipment for process control, monitoring, and instrumentation was not investigated for this study. Estimation factors for instrumentation were used in the calculation of the total capital cost. This factor was rated at $30 \%$ of the purchased equipment cost and it is assumed that this factor will adequately cover any costs incurred for instrumentation, monitoring, and process control equipment. 


\section{Pressure Vessels and Compressors}

From Figure 14-48 in Peters and Timmerhaus, p. 530 (Peters 1991), costs for a compressor are given. A sensitivity study was conducted to determine if replacing the retention tanks with pressure vessels would provide a cost savings since the gas volume would be compressed. A pressure of 112.5 psi was used for the calculations and a compressor was chosen for moving the gas. Calculations found that a 4,000 hp compressor would be needed for the high-flow case and 1,100 hp for the $\mathrm{O}_{2}$-case. A centrifugal motor compressor was chosen and for the air and Low-flow cases, the costs were calculated to be $\$ 1,386,000$ and $\$ 416,000$, respectively. These are the costs for one compressor. In calculating the capital costs of the entire system, two compressors were costed assuming that a backup would be needed in case of failure or other unforeseen need. Due to the compression of the gas, it was determined that a $125,000 \mathrm{~m}^{3}$ vessel would be needed to contain the gas from the high-flow case and a $35,000 \mathrm{~m}^{3}$ vessel for the $\mathrm{O}_{2}$-case. Using design equations for spherical shell pressure vessels from Tables 4 and 6 of Peters and Timmerhaus (Peters 1991) and adjusting to 1997 costs, the cost for a pressure vessel for the high-flow case were calculated to be in the range of $\$ 6.3-8.7$ million. For the Low-flow case, the pressure vessel cost was calculated to be in the range of $\$ 2.6-3.9$ million. Three such pressure vessels were costed in the computation of the capital costs. Use of pressure vessels rather than retention tanks will offer a significant cost savings. 


\section{APPENDIX D}

\section{ASPEN PLUS: Process Simulation Code}

ASPEN PLUS (hereafter referred to as ASPEN) is the process simulation code that was used to model the selected high-performance offgas system. ASPEN calculates mass and energy balances around each unit operation using chemical reaction and equilibrium data specified by the user or retrieved from an extensive database. ASPEN also possesses the capability of modeling solids handling processes such as particulate filtration. These features make ASPEN a powerful tool for evaluating APCS design.

An ASPEN simulation flowsheet consists of blocks and streams. Material streams enter and exit blocks. Each feedstream must have its stream conditions and composition specified by the user. Stream conditions are specified by two of the following variables - temperature, pressure, and vapor fraction. Feed composition can be specified by total stream flowrate and component fractions or by the individual component flowrates. Most blocks represent unit operations where physical or chemical processes cause the chemical species in the feedstream(s) to react, mix, or separate. Each block representing a unit operation must have its operating conditions and performance specified, or it can identify operating conditions and performance based on such factors as feedstream conditions and compositions and any heat input/loss. A brief description of the block types used in the model are listed in Table D-1. The block types used to model each APCS component are described in Table D-2.

In addition to specifying the blocks and streams in a process flowsheet, the user must specify the components in the process and the physical property databanks to be used. Selecting the correct physical property package is critical for obtaining valid simulation results. If physical property parameters do not exist in ASPEN for a component, the user can add those properties or otherwise supplement ASPEN so that the missing physical properties can be estimated.

The ASPEN-generated flowsheet of the offgas system described in Section 4 is shown in Figure D-1. This figure is more complex than the simplified block diagram for the baseline system shown in Figures 6-1 and 6-2 because additional ASPEN blocks were often needed to model offgas equipment. Feed streams enter the APCS, product streams exit the APCS, and intermediate streams pass between different unit operations in the APCS. The streams used in the model are summarized in Table D-3.

Simulation results for the high-flow and low-flow cases are listed in Tables D-4 and D-5. The substream label MIXED describes streams that contain materials in gas and vapor phases. All other substream labels apply to particulate substreams. 
Table D-1. ASPEN block types used in APCS model.

\begin{tabular}{|c|c|}
\hline Block type & Description \\
\hline RGIBBS & $\begin{array}{l}\text { Reactor model that computes simultaneous phase and chemical equilibrium by Gibbs } \\
\text { free energy minimization with phase splitting. Reaction stoichiometry is not needed. } \\
\text { To restrict equilibrium, specify the extent of reaction or fraction of component that does } \\
\text { not react. Also computes the chemical equilibria between any number of conventional } \\
\text { solid components and the fluid phases. }\end{array}$ \\
\hline
\end{tabular}

RSTOIC Reactor model that simulates reactor when reaction kinetics are unknown or unimportant but the stoichiometry is known.

FABFL Gas-solid separator model used to separate an inlet gas stream containing solids into a solids stream and a gas stream carrying residual solids. Can be used to design baghouse unit. Also used to specify particulate removal by particle size.

HEATER Block used to determine thermal and phase conditions of a mixture of one or more inlet streams, given specifications from among temperature, pressure, heat duty, or vapor fraction. Applications include heaters, coolers, valves, pumps, and compressors.

FLASH2 Block used to determine the thermal and phase conditions of a mixture of one or more inlet streams, given specifications from among temperature, pressure, heat duty, or vapor fraction. Performs vapor-liquid and vapor-liquid-liquid equilibrium calculations. Applications include flashes, evaporators, and most single-stage separators.

COMPR Block used to calculate power requirement of polytropic or isentropic compressors to change fluid pressure.

SEP Combine streams and separates the result into two or more streams according to splits specified for each component. Can be used in place of a rigorous separation model to save computation time when details of separation are unknown or unimportant but splits for each component are known.

FSPLIT Combines streams and divides the resulting stream into two or more streams. All outlets have the same composition and properties as the mixed inlet.

MIXER Combines streams into one stream.

CLCHNG Changes stream class. It is used between blocks for which different stream classes are used. This block does not perform a real unit operation.

MULT Multiplies component flowrates and total flowrates of a stream by a factor supplied by user. It is useful when possible roundoff to zero of stream value may result due to value being less than minimum cutoff. 
Table D-2. ASPEN PLUS model for the R-1 offgas system.

\begin{tabular}{|c|c|c|c|c|c|}
\hline $\begin{array}{l}\text { Block name } \\
\text { (ASPEN block } \\
\text { type) }\end{array}$ & $\begin{array}{c}\text { Unit } \\
\text { operation }\end{array}$ & $\begin{array}{l}\text { Other ASPEN } \\
\text { blocks used }\end{array}$ & Inlet streams & Outlet streams & Description and assumptions \\
\hline $\begin{array}{l}\text { SPRAQNCH } \\
\text { (RGIBBS) }\end{array}$ & $\begin{array}{l}\text { Spray } \\
\text { quench }\end{array}$ & $\begin{array}{l}\text { SEP } \\
\text { (SEPA, SEPHG) } \\
\text { CLCHNG (CH1,CH2, } \\
\text { CHG1, CHG2) } \\
\text { RSTOIC } \\
\text { (RS-A, RS-HG) } \\
\text { MIXER } \\
\text { (MIXA, MIXHG) } \\
\text { RGIBBS (RGHG) }\end{array}$ & $\begin{array}{l}\text { SCCGASO } \\
\mathrm{H} 2 \mathrm{O}-\mathrm{SQ}\end{array}$ & SPRAYOUT & $\begin{array}{l}\text { Adiabatic evaporative water spray quench to cool secondary } \\
\text { combustion chamber (SCC) offgas to } 300^{\circ} \mathrm{F} \text { before entering } \\
\text { baghouse. The input offgas composition and temperature is } \\
\text { specified. Clean water is fed into process at } 60^{\circ} \mathrm{F} \text {, and is fully } \\
\text { evaporated to cool the outlet gas stream to } 300^{\circ} \mathrm{F} \text {. The reaction } \\
\text { temperature for } \mathrm{Hg} \text { and } \mathrm{HCl} \text { is fixed at } 980^{\circ} \mathrm{F} \text {, to reflect kinetic } \\
\text { limitation of reaction. } \mathrm{Blocks} \text { denoted by } \mathrm{HG} \text { allow remaining } \mathrm{Hg} \text { to } \\
\text { react completely with } \mathrm{Cl}_{2} \text { in system and calculate thermal properties } \\
\text { at } 300^{\circ} \mathrm{F} \text {. }\end{array}$ \\
\hline $\begin{array}{l}\text { BAGHOUSE } \\
\text { (FABFL) }\end{array}$ & Baghouse & & BHIN & $\begin{array}{l}\text { BGASSOL } \\
\text { BAGSOLID }\end{array}$ & $\begin{array}{l}\text { Performs particulate removal from the input gas stream. Also used } \\
\text { to determine number of filter bags, filtration surface area, number of } \\
\text { cells, and baghouse footprint. The pressure drop across filter and } \\
\text { filter efficiency as a function of particle size were specified. } \\
\text { Removal efficiencies of } 99.9 \% \text { and } 99 \% \text { for particles greater than } \\
\text { and less than } 0.5 \mu \mathrm{m} \text {, respectively, were assumed. }\end{array}$ \\
\hline $\begin{array}{l}\text { QUENCH } \\
\text { (RGIBBS) }\end{array}$ & $\begin{array}{l}\text { Quench } \\
\text { cooler }\end{array}$ & $\begin{array}{l}\text { SEP (SEPB) } \\
\text { CLCHNG (CH3,CH4) } \\
\text { RSTOIC (RS-B) } \\
\text { HEATER (HTRB) }\end{array}$ & $\begin{array}{l}\text { BAGGAS0 } \\
\mathrm{H} 2 \mathrm{O}-\mathrm{Q}\end{array}$ & QGASSOL & $\begin{array}{l}\text { Adiabatic evaporative water spray quench cooler designed to cool } \\
\text { gas to saturation conditions before entering the acid gas scrubber. } \\
\text { Clean water is fed into process at } 60^{\circ} \mathrm{F} \text {. }\end{array}$ \\
\hline $\begin{array}{l}\text { SCRUBBER } \\
\text { (RGIBBS) }\end{array}$ & $\begin{array}{l}\text { Acid gas } \\
\text { wet scrubber }\end{array}$ & $\begin{array}{l}\text { SEP (SEPC, SEPD, } \\
\text { SEPE, SEPR) } \\
\text { CLCHNG(CH5, CH6, } \\
\text { CH7) } \\
\text { RSTOIC (RS-C, RS-D) } \\
\text { MIXER (MIXC, MIXE, } \\
\text { MIXR) } \\
\text { HEATER(HTRD,HTRF) } \\
\text { FLASH2 (FLSHD) } \\
\text { FABFL (FILTE) } \\
\text { FSPLIT (SPLTD, } \\
\text { SPLTE) } \\
\text { MULT (M1,M2) }\end{array}$ & $\begin{array}{l}\text { QNCHGAS } \\
\text { SCRUBAIR } \\
\text { NAOH } \\
\text { SCRUBLIQ }\end{array}$ & SCRUBOUT & $\begin{array}{l}\text { Assumed that acid gas scrubber removes } 99 \% \mathrm{SO}_{2} \text { and } 99.9 \% \mathrm{HCl} \\
\text { in gas. A } 1 \% \text { excess of } \mathrm{NaOH} \text { is added to ensure liquid } \mathrm{pH} \text { greater } \\
\text { than } 7 \text {. The liquid stream exiting process is recycled to maintain } \\
\text { liquid flowrate ( } 30 \text { or } 60 \text { gpm). Excess liquid from condensed or } \\
\text { makeup water exits the process as discharge along with solids and } \\
\text { acid gases removed by scrubber. The particulate concentration in } \\
\text { scrubber outlet offgas depends on the atomizing air flowrate to } \\
\text { scrubber (SCRUBAIR) and mass ratio of the scrubber liquid and the } \\
\text { offgas. FABFL is used to specify pressure drop across scrubber. } \\
100 \% \text { removal of particles greater than } 0.5 \mu \mathrm{m} \text { is assumed, based on } \\
\text { vendor information. The FSPLIT block (SPLTE) is adjusted to } \\
\text { achieve solid concentration in exit gas for a given value of } \\
\text { SCRUBAIR. }\end{array}$ \\
\hline
\end{tabular}


Table D-2. ASPEN PLUS model for the R-1 offgas system (continued).

\begin{tabular}{|c|c|c|c|c|c|}
\hline $\begin{array}{l}\text { Block name } \\
\text { (ASPEN block } \\
\text { type) }\end{array}$ & $\begin{array}{c}\text { Unit } \\
\text { operation }\end{array}$ & $\begin{array}{l}\text { Other ASPEN } \\
\text { blocks used }\end{array}$ & Inlet streams & Outlet streams & Description and assumptions \\
\hline $\begin{array}{l}\text { CHILLER } \\
\text { (HEATER) }\end{array}$ & Chiller & & CHILLIN & CHILLOUT & $\begin{array}{l}\text { Removes heat from the system by cooling the hot scrubber liquid } \\
\text { recycle from the scrubber outlet temperature to } 60^{\circ} \mathrm{F} \text {. }\end{array}$ \\
\hline $\begin{array}{l}\text { HEATER } \\
\text { (HEATER) }\end{array}$ & $\begin{array}{l}\text { Gas } \\
\text { reheater }\end{array}$ & $\begin{array}{l}\text { SEP (SEPG) } \\
\text { CLCHNG (CH8, CH9) } \\
\text { MIXER (MIXG) } \\
\text { RSTOIC (RS-G, RS-H) } \\
\text { MULT (M3, M5) }\end{array}$ & AIR & HOTAIR & $\begin{array}{l}\text { Reheats the saturated offgas exiting the scrubber to avoid water } \\
\text { droplets or moisture condensation in the downstream equipment. } \\
\text { Clean ambient air is heated and added to the gas stream entering } \\
\text { prefilter to raise the gas temperature and ensure that moisture does } \\
\text { not condense. Air is heated to } 1,000^{\circ} \mathrm{F} \text {. The air flowrate is adjusted } \\
\text { so when mixed with scrubber offgas it will increase offgas } \\
\text { temperature at least } 40^{\circ} \mathrm{F} \text { above the dewpoint of the air and offgas } \\
\text { mixture. Because the air is relatively dry, it also lowers the } \\
\text { dewpoint of the offgas. }\end{array}$ \\
\hline $\begin{array}{l}\text { PREFILTR } \\
\text { (FABFL) }\end{array}$ & Prefilter & MULT (M7) & REHOUT & $\begin{array}{l}\text { HEPAIIN } \\
\text { PREFSOL }\end{array}$ & $\begin{array}{l}\text { This is a coarse filter to protect the HEPAs. FABFL used to specify } \\
\text { pressure drop across prefilter and particulate removal efficiency as } \\
\text { function of particle size. Based on data from Flanders Filter, } \\
\text { particulate removal efficiencies were assumed to be } 87 \% \text { for } 0.5 \mu \mathrm{m} \\
\text { particles, } 70 \% \text { for } 0.3 \mu \mathrm{m} \text {, and } 87 \% \text { for particles less than } 0.1 \mu \mathrm{m} \text {. }\end{array}$ \\
\hline $\begin{array}{l}\text { HEPA1 } \\
\text { (FABFL) }\end{array}$ & HEPA filter & MULT (M8) & HEPAIIN & $\begin{array}{l}\text { HEPAGAS1 } \\
\text { HEPASOL1 }\end{array}$ & $\begin{array}{l}\text { FABFL is used to specify pressure drop across the filter and } \\
\text { particulate removal efficiency as function of particle size. As } \\
\text { certified HEPAs, a removal efficiency of } 99.97 \% \text { for } 0.3 \mu \mathrm{m} \\
\text { particles was used for these filters. }\end{array}$ \\
\hline $\begin{array}{l}\text { HGCBED } \\
\text { (SEP) }\end{array}$ & $\begin{array}{l}\text { Mercury } \\
\text { adsorption } \\
\text { carbon bed }\end{array}$ & MULT (M9) & HEPAGAS1 & $\begin{array}{l}\text { HEPA2IN } \\
\text { HGACC }\end{array}$ & $\begin{array}{l}\text { The S-impregnated carbon beds are designed to remove mercury } \\
\text { vapor in gas stream. Mercury accumulates in bed but is represented } \\
\text { in ASPEN as an exit stream from block. A total Hg removal } \\
\text { efficiency of } 99 \% \text { is assumed. No pressure drop nor additional } \\
\text { particulate removal is assumed. }\end{array}$ \\
\hline $\begin{array}{l}\text { HEPA2 } \\
\text { (FABFL) }\end{array}$ & HEPA filter & MULT (M10) & HEPA2IN & $\begin{array}{l}\text { HEPAGAS2 } \\
\text { HEPASOL2 }\end{array}$ & $\begin{array}{l}\text { FABFL used to specify pressure drop across filter and particulate } \\
\text { removal efficiency as function of particle size. Even though these } \\
\text { are certified HEPAs, a removal efficiency of only was used } 99.9 \% \\
\text { for all particles less than } 0.5 \mu \mathrm{m} \text {. }\end{array}$ \\
\hline
\end{tabular}


Table D-2. ASPEN PLUS model for the R-1 offgas system (continued).

\begin{tabular}{|c|c|c|c|c|c|}
\hline $\begin{array}{l}\text { Block name } \\
\text { (ASPEN block } \\
\text { type) }\end{array}$ & $\begin{array}{c}\text { Unit } \\
\text { operation }\end{array}$ & $\begin{array}{l}\text { Other ASPEN } \\
\text { blocks used }\end{array}$ & Inlet streams & Outlet streams & Description and assumptions \\
\hline $\begin{array}{l}\text { REH-NOX } \\
\text { (RGIBBS) }\end{array}$ & $\begin{array}{l}\text { Reheater, } \\
\text { Catalytic } \\
\text { reactor }\end{array}$ & $\begin{array}{l}\text { SEP (REHSEP) } \\
\text { CLCHNG (CHA,CHB) } \\
\text { MIXER (REHMIX) } \\
\text { MULT (M4, M11) }\end{array}$ & $\begin{array}{l}\text { NOXIN } \\
\text { NH3 }\end{array}$ & NOXOUT & $\begin{array}{l}\text { The offgas is reheated and treated to reduce } \mathrm{NO}_{\mathrm{x}} \text { levels. An } \\
\text { RGIBBS block is used to represent the heating the offgas and } \mathrm{NH}_{3} \\
\text { to } 400^{\circ} \mathrm{F} \text { before entering a catalytic reactor. } \mathrm{ANO}_{\mathrm{x}} \text { removal } \\
\text { efficiency of } 85 \% \text { is assumed. }\end{array}$ \\
\hline $\begin{array}{l}\text { ZFLASH } \\
\text { (FLASH2) }\end{array}$ & Condenser & & EXITGAS & $\begin{array}{l}\text { ZLIQ } \\
\text { ZVAP }\end{array}$ & $\begin{array}{l}\text { Exit gas is cooled to condense and remove water and reduce the gas } \\
\text { volumetric flowrate. }\end{array}$ \\
\hline $\begin{array}{l}\text { COMP } \\
\text { (COMPR) }\end{array}$ & Compressor & & ZVAP & COMPV & Compressor for pressurizing the gas into retention tanks. \\
\hline
\end{tabular}




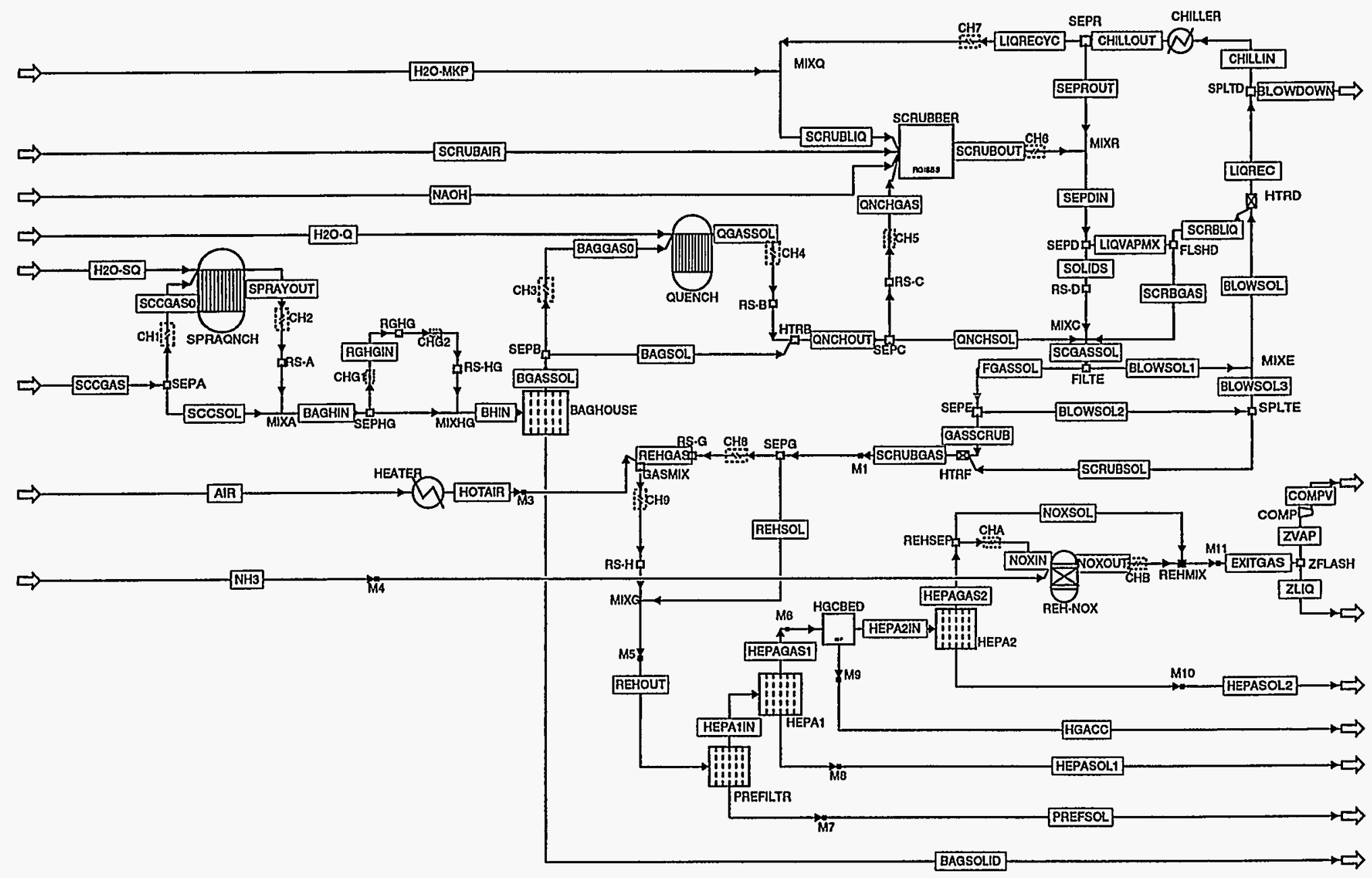

Figure D-1. ASPEN-generated flowsheet of the baseline high-performance APCS. 
Table D-3. Streams in ASPEN PLUS model.

\begin{tabular}{|c|c|c|c|c|c|c|}
\hline Stream name & Stream type & $\begin{array}{l}\text { Exits block type } \\
\text { (block name) }\end{array}$ & $\begin{array}{l}\text { Enters block type } \\
\text { (block name) }\end{array}$ & $\begin{array}{l}\text { Stream } \\
\text { temp. }\left({ }^{\circ} \mathrm{F}\right)\end{array}$ & $\begin{array}{c}\text { Stream } \\
\text { pres. (psia) }\end{array}$ & Description \\
\hline SCCGAS & FEED & - & SEP (SEPA) & 2,200 & 12.5 & $\begin{array}{l}\text { Offgas exiting secondary } \\
\text { combustion chamber }\end{array}$ \\
\hline $\mathrm{H} 2 \mathrm{O}-\mathrm{SQ}$ & FEED & - & $\begin{array}{c}\text { RGIBBS } \\
\text { (SPRAQNCH) }\end{array}$ & 60 & 12.5 & Clean water for quench \\
\hline SCCGASO & INTERMEDIATE & CLCHNG (CH1) & $\begin{array}{c}\text { RGIBBS } \\
\text { (SPRAQNCH) }\end{array}$ & & & $\begin{array}{l}\text { Vapor from stream } \\
\text { SCCGAS }\end{array}$ \\
\hline SCCSOL & INTERMEDIATE & SEP (SEPA) & MIXER (MIXA) & & & $\begin{array}{l}\text { Solids from stream } \\
\text { SCCGAS }\end{array}$ \\
\hline SPRAYOUT & INTERMEDIATE & $\begin{array}{c}\text { RGIBBS } \\
\text { (SPRAQNCH) }\end{array}$ & CLCHNG (CH2) & . & & $\begin{array}{l}\text { Gas and new solids from } \\
\text { SPRAQNCH }\end{array}$ \\
\hline BAGHIN & INTERMEDIATE & MIXER (MIXA) & SEP (SEPHG) & & & $\begin{array}{l}\text { Total gas/solids after } \\
\text { SPRAQNCH block }\end{array}$ \\
\hline BHIN & INTERMEDIATE & MIXER (MIXHG) & $\begin{array}{c}\text { FABFL } \\
\text { (BAGHOUSE) }\end{array}$ & & & $\begin{array}{l}\text { Total gas/solids entering } \\
\text { BAGHOUSE }\end{array}$ \\
\hline RGHGIN & INTERMEDIATE & CLCHNG (CHG1) & RGIBBS (RGHG) & & & $\begin{array}{l}\text { Gas/vapor from stream } \\
\text { BAGHIN }\end{array}$ \\
\hline BGASSOL & INTERMEDIATE & $\begin{array}{c}\text { FABFL } \\
\text { (BAGHOUSE) }\end{array}$ & SEP (SEPB) & & & Gas/solids in offgas \\
\hline BAGSOLID & PRODUCT & $\begin{array}{c}\text { FABFL } \\
\text { (BAGHOUSE) }\end{array}$ & - & & & $\begin{array}{l}\text { Collected solids from } \\
\text { BAGHOUSE }\end{array}$ \\
\hline BAGSOL & INTERMEDIATE & SEP (SEPB) & HEATER (HTRB) & & & $\begin{array}{l}\text { Solids from stream } \\
\text { BGASSOL }\end{array}$ \\
\hline BAGGASO & INTERMEDIATE & CLCHNG (CH3) & $\begin{array}{l}\text { RGIBBS } \\
\text { (QUENCH) }\end{array}$ & & & $\begin{array}{l}\text { Gas/vapor from stream } \\
\text { BGASSOL }\end{array}$ \\
\hline $\mathrm{H} 20-\mathrm{Q}$ & FEED & - & $\begin{array}{l}\text { RGIBBS } \\
\text { (QUENCH) }\end{array}$ & 60 & 12.5 & Clean water for quench \\
\hline QGASSOL & INTERMEDIATE & $\begin{array}{c}\text { RGIBBS } \\
\text { (QUENCH) }\end{array}$ & CLCHNG (CH4) & & & $\begin{array}{l}\text { Gas and new solids from } \\
\text { QUENCH }\end{array}$ \\
\hline QNCHOUT & INTERMEDIATE & HEATER (HTRB) & SEP (SEPC) & & & $\begin{array}{l}\text { Total gas/solids after total } \\
\text { quench }\end{array}$ \\
\hline QNCHSOL & INTERMEDLATE & SEP (SEPC) & MIXER (MIXC) & & & $\begin{array}{l}\text { Solids from stream } \\
\text { QNCHOUT }\end{array}$ \\
\hline QNCHGAS & INTERMEDIATE & CLCHNG (CH5) & $\begin{array}{c}\text { RGIBBS } \\
\text { (SCRUBBER) }\end{array}$ & & & $\begin{array}{l}\text { Gas/vapor from stream } \\
\text { QNCHOUT }\end{array}$ \\
\hline $\mathrm{NAOH}$ & FEED & - & $\begin{array}{c}\text { RGIBBS } \\
\text { (SCRUBBER) }\end{array}$ & 77 & 12.5 & $\begin{array}{l}\text { Added to neutralize acid } \\
\text { gases }\end{array}$ \\
\hline SCRUBAIR & FEED & - & $\begin{array}{c}\text { RGIBBS } \\
\text { (SCRUBBER) }\end{array}$ & 100 & 65 & Atomizing air \\
\hline H2O-MKP & FEED & - & MIXER (MIXQ) & 60 & 12.5 & $\begin{array}{l}\text { Make-up water (used in } \\
\text { O2-combustion only) }\end{array}$ \\
\hline
\end{tabular}


Table D-3. Streams in ASPEN PLUS model (continued).

\begin{tabular}{|c|c|c|c|c|c|c|}
\hline Stream name & Stream type & $\begin{array}{l}\text { Exits block type } \\
\text { (block name) }\end{array}$ & $\begin{array}{l}\text { Enters block type } \\
\text { (block name) }\end{array}$ & $\begin{array}{l}\text { Stream } \\
\text { temp. }\left({ }^{\circ} \mathrm{F}\right)\end{array}$ & $\begin{array}{c}\text { Stream } \\
\text { pres. (psia) }\end{array}$ & Description \\
\hline LIQRECYC & NTTERMEDIATE & SEP (SEPR) & CLCHNG (CH7) & & & $\begin{array}{l}\text { Liquid flow recycle to } \\
\text { scrubber }\end{array}$ \\
\hline SCRUBLIQ & INTERMEDIATE & MIXER (MIXQ) & $\begin{array}{c}\text { RGIBBS } \\
\text { (SCRUBBER) }\end{array}$ & & & $\begin{array}{l}\text { Complete liquid flow to } \\
\text { scrubber } \\
\text { (LIQRECYC+H2O-MKP) }\end{array}$ \\
\hline SCRUBOUT & INTERMEDIATE & $\begin{array}{c}\text { RGIBBS } \\
\text { (SCRUBBER) }\end{array}$ & CLCHNG (CH6) & & & $\begin{array}{l}\text { Gas/solids/salt from } \\
\text { SCRUBBER }\end{array}$ \\
\hline SEPROUT & INTERMEDIATE & SEP (SEPR) & MIXER (MIXR) & & & Recycled solids \\
\hline SEPDIN & INTERMEDIATE & MIXER (MIXR) & SEP (SEPD) & & & All phases from scrubber \\
\hline SOLIDS & NNTERMEDIATE & SEP (SEPD) & RSTOIC (RS-D) & & & $\begin{array}{l}\text { Solids from stream } \\
\text { SEPDIN }\end{array}$ \\
\hline LIQVAPMX & INTERMEDIATE & SEP (SEPD) & FLASH2 (FLSHD) & & & $\begin{array}{l}\text { Gas/liquid/salt from } \\
\text { SEPDIN }\end{array}$ \\
\hline SCRBGAS & INTERMEDIATE & FLASH2 (FLSHD) & MIXER (MIXC) & & & $\begin{array}{l}\text { Saturated gas exiting } \\
\text { scrubber }\end{array}$ \\
\hline SCRBLIQ & INTERMEDIATE & FLASH2 (FLSHD) & HEATER (HTRD) & & & Liquid exiting scrubber \\
\hline LIQREC & INTERMEDIATE & HEATER (HTRD) & FSPLIT (SPLTD) & & & $\begin{array}{l}\text { Total recycled liquid/solid } \\
\text { from scrubber }\end{array}$ \\
\hline CHILLIN & INTERMEDIATE & FSPLIT (SPLTD) & $\begin{array}{c}\text { HEATER } \\
\text { (CHILLER) }\end{array}$ & & & $\begin{array}{l}\text { Recycled liquid entering } \\
\text { chiller }\end{array}$ \\
\hline CHILLOUT & INTERMEDIATE & $\begin{array}{l}\text { HEATER } \\
\text { (CHILLER) }\end{array}$ & SEP (SEPR) & & & $\begin{array}{l}\text { Recycled liquid exiting } \\
\text { chiller }\end{array}$ \\
\hline SCGASSOL & INTERMEDIATE & MIXER (MIXC) & FABFL (FILTE) & & & $\begin{array}{l}\text { Combined gas/solids } \\
\text { streams }\end{array}$ \\
\hline BLOWSOL1 & NTERMEDIATE & FABFL (FILTE) & MIXER (MIXE) & & & $\begin{array}{l}\text { All particles }>0.5 \mu \mathrm{m} \\
\text { removed by scrubber }\end{array}$ \\
\hline FGASSOL & INTERMEDIATE & FABFL (FILTE) & SEP (SEPE) & & & $\begin{array}{l}\text { SCGASSOL gas/solids < } \\
0.5 \mu \mathrm{m}\end{array}$ \\
\hline BLOWSOL2 & INTERMEDIATE & SEP (SEPE) & FSPLIT (SPLTE) & & & FGASSOL solids $<0.5 \mu \mathrm{m}$ \\
\hline GASSCRUB & INTERMEDIATE & SEP (SEPE) & HEATER (HTRF) & & & $\begin{array}{l}\text { Gas/vapor exiting } \\
\text { SCRUBBER }\end{array}$ \\
\hline BLOWSOL3 & INTERMEDIATE & FSPLIT (SPLTE) & MIXER (MIXE) & & & $\begin{array}{l}\text { Small particles removed by } \\
\text { scrubber }\end{array}$ \\
\hline BLOWSOL & INTERMEDIATE & MULT (M2) & MIXER (MIXD) & & & $\begin{array}{l}\text { Particles removed by } \\
\text { scrubber }\end{array}$ \\
\hline BLOWDOWN & PRODUCT & FSPLIT (SPLTD) & - & & & Blowdown from scrubber \\
\hline SCRUBGAS & INTERMEDIATE & HEATER (HTRF) & MULT (M1) & & & $\begin{array}{l}\text { Gas/particles exiting } \\
\text { scrubber }\end{array}$ \\
\hline REHGAS & INTERMEDLATE & RSTOIC (RS-G) & $\begin{array}{l}\text { RGIBBS } \\
\text { (GASMIX) }\end{array}$ & & & $\begin{array}{l}\text { Gas/vapor from stream } \\
\text { REHIN }\end{array}$ \\
\hline
\end{tabular}


Table D-3. Streams in ASPEN PLUS model (continued).

\begin{tabular}{|c|c|c|c|c|c|c|}
\hline Stream name & Stream type & $\begin{array}{l}\text { Exits block type } \\
\text { (block name) }\end{array}$ & $\begin{array}{l}\text { Enters block type } \\
\text { (block name) }\end{array}$ & $\begin{array}{c}\text { Stream } \\
\text { temp. }\left({ }^{\circ} \mathrm{F}\right)\end{array}$ & $\begin{array}{c}\text { Stream } \\
\text { pres. (psia) }\end{array}$ & Description \\
\hline REHSOL & INTERMEDIATE & SEP (SEPG) & MIXER (MIXG) & & & $\begin{array}{l}\text { Particulate in stream } \\
\text { REHIN }\end{array}$ \\
\hline AIR & FEED & - & $\begin{array}{c}\text { HEATER } \\
\text { (HEATER) }\end{array}$ & 77 & 12.5 & Humid ambient air \\
\hline HOTAIR & INTERMEDIATE & $\begin{array}{l}\text { HEATER } \\
\text { (HEATER) }\end{array}$ & MULT (M3) & 1,000 & 12.5 & Heated stream AIR \\
\hline REHOUT & INTERMEDIATE & MULT (M5) & $\begin{array}{c}\text { FABFL } \\
\text { (PREFILTR) }\end{array}$ & & & $\begin{array}{l}\text { Heated gas/solids entering } \\
\text { prefilter }\end{array}$ \\
\hline PREFSOL & PRODUCT & MULT (M7) & - & & & Solids removed by prefilter \\
\hline HEPAIIN & INTERMEDLATE & $\begin{array}{c}\text { FABFL } \\
\text { (PREFILTR) }\end{array}$ & FABFL (HEPA1) & & & $\begin{array}{l}\text { Gas/solids entering first } \\
\text { HEPA filter }\end{array}$ \\
\hline HEPASOLI & PRODUCT & MULT (M8) & - & & & $\begin{array}{l}\text { Solids removed by first } \\
\text { HEPA filter }\end{array}$ \\
\hline HEPAGAS1 & INTERMEDIATE & FABFL (HEPA1) & MULT (M6) & & & $\begin{array}{l}\text { Gas/solids entering carbon } \\
\text { bed }\end{array}$ \\
\hline HGACC & PRODUCT & MULT (M9) & - & & & $\begin{array}{l}\text { Mercury removed by } \\
\text { carbon bed }\end{array}$ \\
\hline HEPA2IN & INTERMEDIATE & SEP (HGCBED) & FABFL (HEPA2) & & & $\begin{array}{l}\text { Gas/solids entering second } \\
\text { HEPA filter }\end{array}$ \\
\hline HEPASOL2 & PRODUCT & MULT (M10) & - & & & $\begin{array}{l}\text { Solids removed by second } \\
\text { HEPA filter }\end{array}$ \\
\hline HEPAGAS2 & INTERMEDIATE & FABFL (HEPA2) & SEP (REHSEP) & & & $\begin{array}{l}\text { Gas/solids entering } \mathrm{NO}_{\mathrm{x}} \\
\text { reactor }\end{array}$ \\
\hline NH3 & FEED & - & MULT (M4) & 77 & 12.5 & Ammonia \\
\hline NOXIN & INTERMEDIATE & CLCHNG (CHA) & $\begin{array}{l}\text { RGIBBS (REH- } \\
\text { NOX) }\end{array}$ & & & $\begin{array}{l}\text { Gas/vapor from stream } \\
\text { HEPAGAS2 }\end{array}$ \\
\hline NOXSOL & INTERMEDIATE & SEP (REHSEP) & MIXER (REHMIX) & & & $\begin{array}{l}\text { Solids from stream } \\
\text { HEPAGAS2 }\end{array}$ \\
\hline NOXOUT & INTERMEDIATE & $\begin{array}{l}\text { RGIBBS (REH- } \\
\text { NOX) }\end{array}$ & CLCHNG (CHB) & 400 & & $\begin{array}{l}\text { Gas/vapor exiting REH- } \\
\text { NOX }\end{array}$ \\
\hline EXITGAS & PRODUCT & MULT (MI1) & - & & & Gas/solids exiting APCS \\
\hline ZLIQ & PRODUCT & $\begin{array}{c}\text { FLASH2 } \\
\text { (ZFLASH) }\end{array}$ & - & 100 & & $\begin{array}{l}\text { Water condensate from } \\
\text { condenser }\end{array}$ \\
\hline ZVAP & INTERMEDLATE & $\begin{array}{l}\text { FLASH2 } \\
\text { (ZFLASH) }\end{array}$ & COMPR (COMP) & 100 & & $\begin{array}{l}\text { Saturated vapor from } \\
\text { condenser }\end{array}$ \\
\hline COMPV & PRODUCT & COMPR (COMP) & - & & & $\begin{array}{l}\text { Compressed gas to storage } \\
\text { tank }\end{array}$ \\
\hline
\end{tabular}


Table D-4. Multiplication factors used in ASPEN PLUS process simulation model.

\begin{tabular}{cc}
\hline Label & Multiplication Factor \\
\hline M1 & $1 \times 10^{4}$ \\
M2 & $1 \times 10^{-4}$ \\
M3 & $1 \times 10^{4}$ \\
M4 & $1 \times 10^{12}$ \\
M5 & $1 \times 10^{4}$ \\
M6 & $1 \times 10^{4}$ \\
M7 & $1 \times 10^{-8}$ \\
M8 & $1 \times 10^{-8}$ \\
M9 & $1 \times 10^{-12}$ \\
M10 & $1 \times 10^{-12}$ \\
M11 & $1 \times 10^{-12}$ \\
\hline
\end{tabular}

\section{D.1 Model Property Sets and Component Databases}

Two property option sets were used to estimate thermodynamic properties in the unit operations where the offgas temperature varies. In the quench towers and heaters, the SOLIDS option set is used to handle the condensation and volatilization of the metal compounds. The ideal gas equation of state is used to describe the vapor phase. In the scrubber where the major component is the recirculated water, the NRTL (non-random two-liquid) option set is used. The NRTL option set uses a Renon activity coefficient model for the liquid phase, an ideal gas equation of state for the vapor phase, the Rackett model for liquid molar volume, and Henry's law for supercritical components. For many simulations, all required binary parameter values are in the ASPEN databanks.

Complete thermodynamic data for some compounds are not in the ASPEN database. By adding property parameters from other sources to the ASPEN database, the equilibrium concentration of these compounds can be estimated. The property parameters required may be molecular weight, critical temperature, the standard free energy and enthalpy of formation for the ideal gas and solid at $25^{\circ} \mathrm{C}$, the coefficients for the heat capacity equation for an ideal gas and solid, coefficients for the Watson heat of vaporization equation, and the coefficients for the Antoine vapor pressure equation.

Equilibrium concentrations predicted by ASPEN PLUS occasionally appeared inconsistent with measurements from actual systems. Reactions, especially at low temperatures, are often limited by kinetics or mass transfer from reaching thermodynamic equilibrium in the offgas system where residence time is measured in seconds or less. In these cases, the predictions can be made to better reflect observed data by 
limiting the extent of reaction or by specifying a reaction temperature at which to calculate the equilibrium composition. Examples of how the model handled nonequilibrium conditions are described below.

\section{D.2 Particulate Formation in ASPEN PLUS Model}

Particulate formation resulting from condensation of volatile metals is expected to occur when the offgas temperature is reduced in the spray quench before the baghouse, the quench unit after the baghouse, and the acid gas scrubber. These chemical reaction phase changes are done in ASPEN using the RGIBBS block. However, the RGIBBS block cannot have particulate-laden gas streams for inputs. So, for each of these unit operations, the following protocol is used in the model:

- The particulate-containing gas stream entering the process is separated into a solids stream and a gas stream.

- The stream class of the gas stream is changed to a RGIBBS-compatible stream class before entering a RGIBBS block.

- After thermodynamic equilibrium is calculated at process conditions, the stream class of the exiting stream is converted back to the global stream class.

- The exiting stream is passed through an RSTOIC block to assign newly formed solids to a new substream with a specific particle size distribution. In all cases, any condensed volatile materials are assumed to form particles via homogeneous condensation with a diameter less than $0.5 \mu \mathrm{m}$. This assumes negligible heterogeneous condensation of volatile materials onto existing particles, although particle growth of new and existing particles up to $0.5 \mu \mathrm{m}$ is allowed. This approach is consistent with findings from studies of metals volatilization, entrainment, condensation, and particle growth where particle sizes down to less than $0.1 \mu \mathrm{m}$ have been evaluated (Sarofim 1997).

- Combine the stream from RSTOIC block with earlier solids stream.

The model also calculated the revolatilization of condensed mercury, arsenic, and selenium compounds when the offgas was heated after the scrubber. Some volatilization of trace particulate containing these compounds occurs when the scrubber offgas is heated to $200^{\circ} \mathrm{F}$, and all particulate containing these compounds is volatilized when the offgas is heated to $400^{\circ} \mathrm{F}$ before the $\mathrm{NO}_{\mathrm{x}}$ catalytic reactor. 


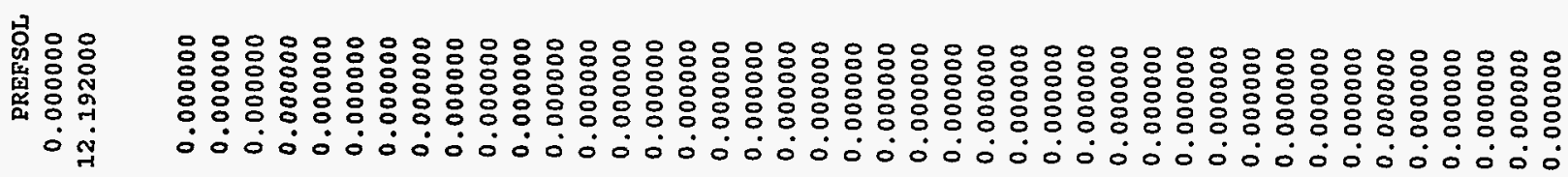

봉요용

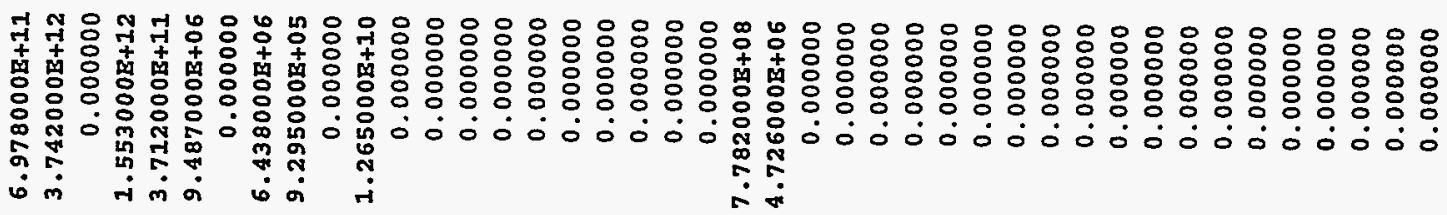

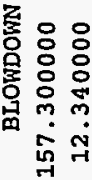

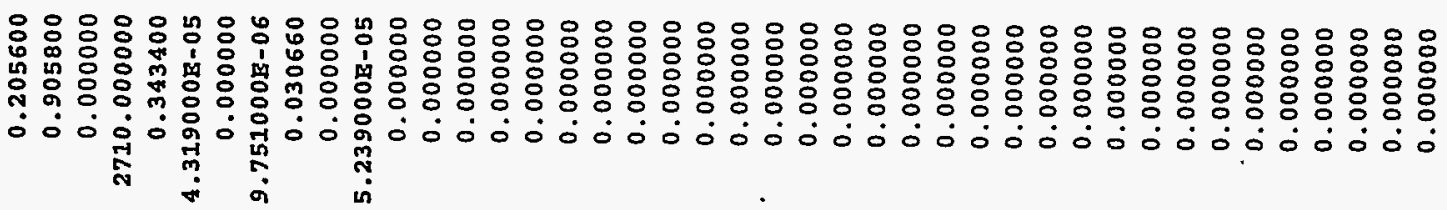

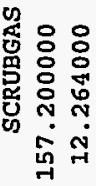

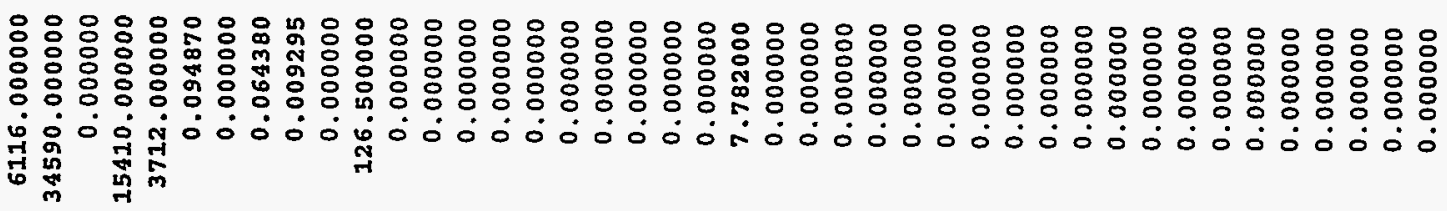

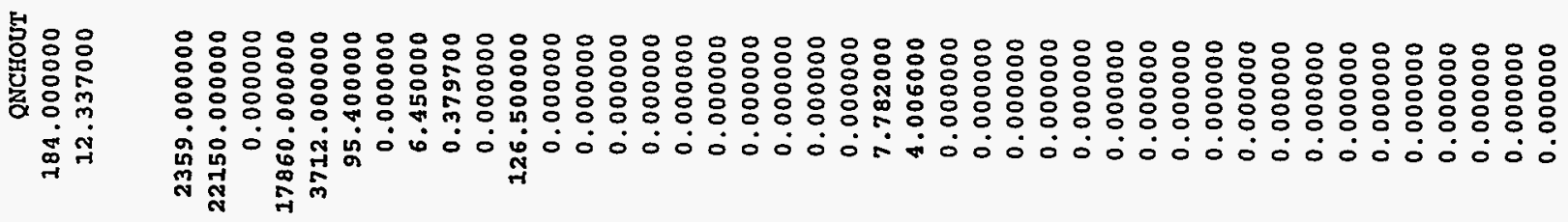

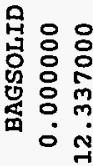

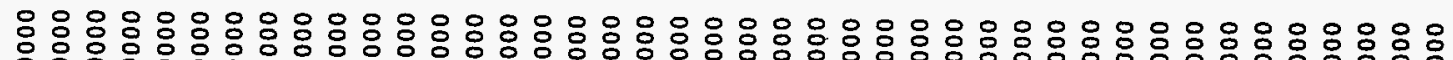

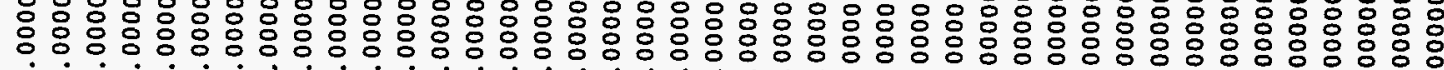
$\dot{0} \dot{0} \dot{0} \dot{0} \dot{0} \dot{0} \dot{0} \dot{0} \dot{0} \dot{0} \dot{0} \dot{0} \dot{0} \dot{0} \dot{0} \dot{0} \dot{0} \dot{0} \dot{0} \dot{0} \dot{0} \dot{0} \dot{0} \dot{0} \dot{0} \dot{0} \dot{0} \dot{0} \dot{0} \dot{0} \dot{0} \dot{0} \dot{0} \dot{0} \dot{0} 0 \dot{0} 0$

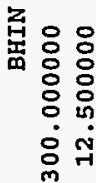

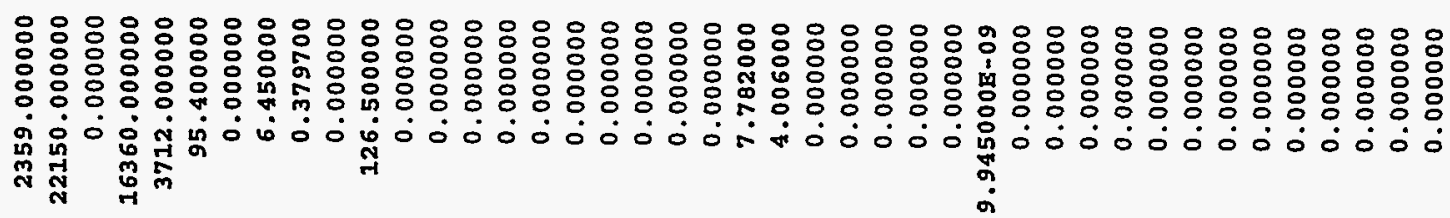

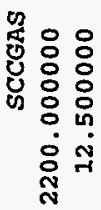

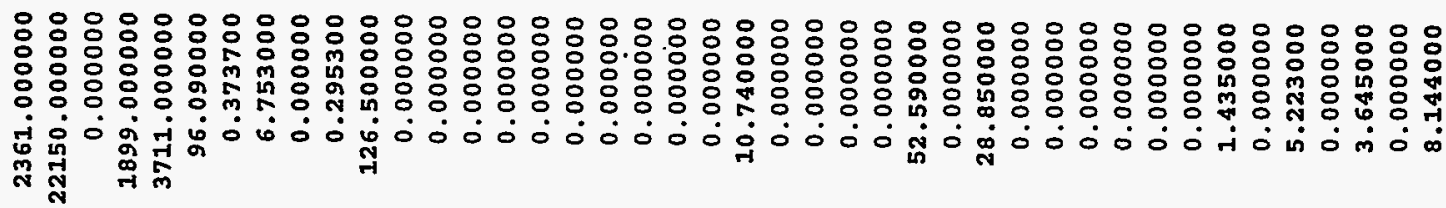

س 
$\circ:$
$\therefore$
$\circ$

$\dot{0} \dot{0}$

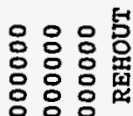

i:

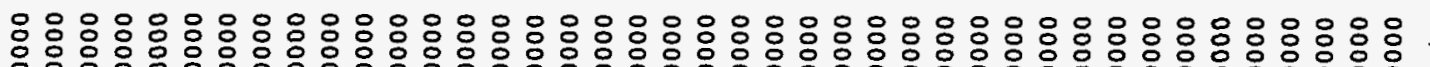

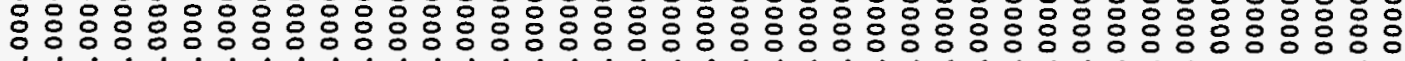
$\dot{0} \dot{0} \dot{0} \dot{0} \dot{0} \dot{0} \dot{0} \dot{0} \dot{0} \dot{0} \dot{0} \dot{0} \dot{0} \dot{0} \dot{0} \dot{0} \dot{0} \dot{0} \dot{0} \dot{0} \dot{0} \dot{0} \dot{0} \dot{0} \dot{0} \dot{0} \dot{0} \dot{0} \dot{0} \dot{0} \dot{0} \dot{0}$

$:$
$\therefore:$

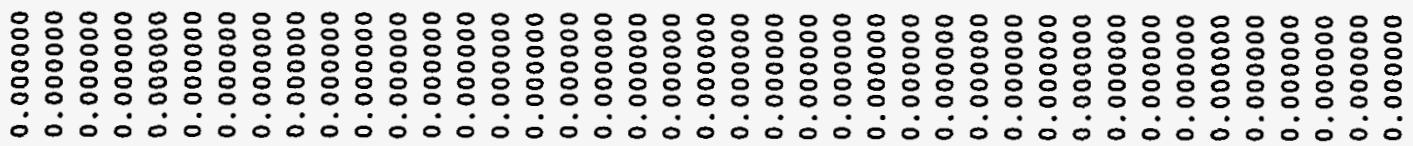

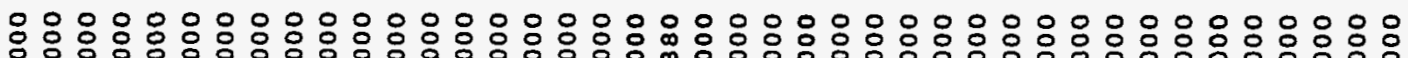

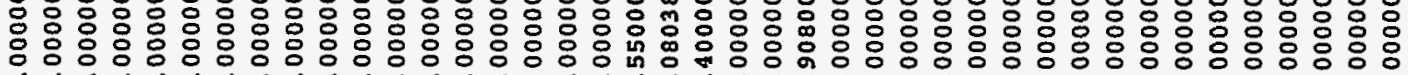

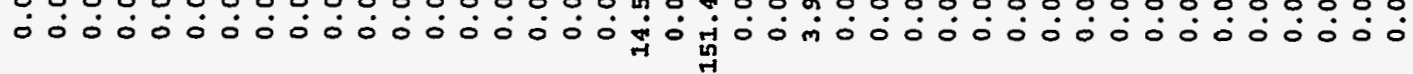

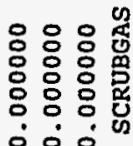

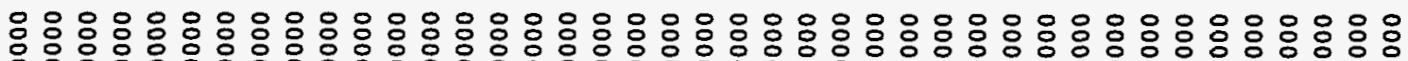

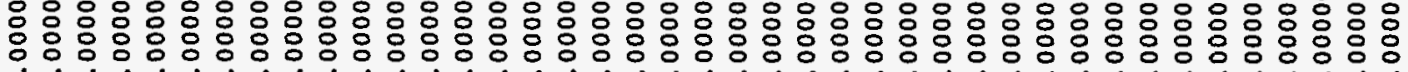

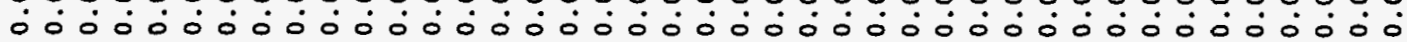

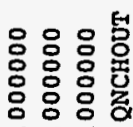

$\because \because \dot{0}$

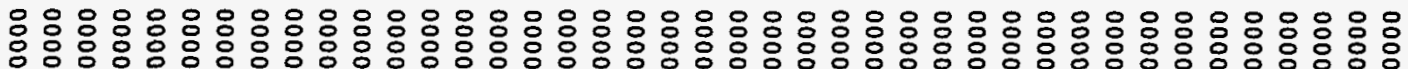

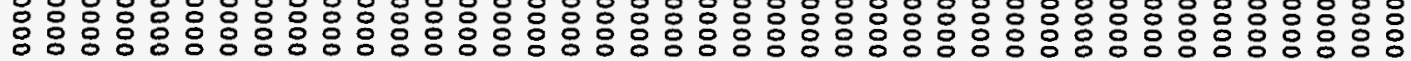

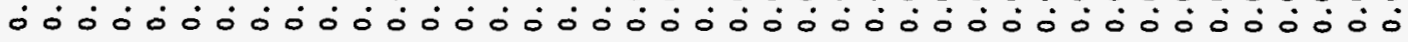

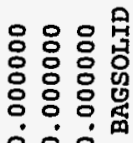

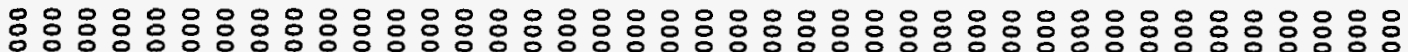

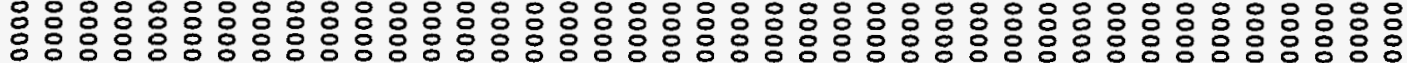
ó0 $\dot{0} \dot{0} \dot{0} \dot{0} \dot{0} \dot{0} \dot{0} \dot{0} \dot{0} \dot{0} \dot{0} \dot{0} \dot{0} \dot{0} \dot{0} \dot{0} \dot{0} \dot{0} \dot{0} \dot{0} \dot{0} \dot{0} \dot{0} \dot{0} \dot{0} \dot{0} \dot{0} \dot{0} 0$

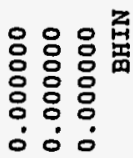

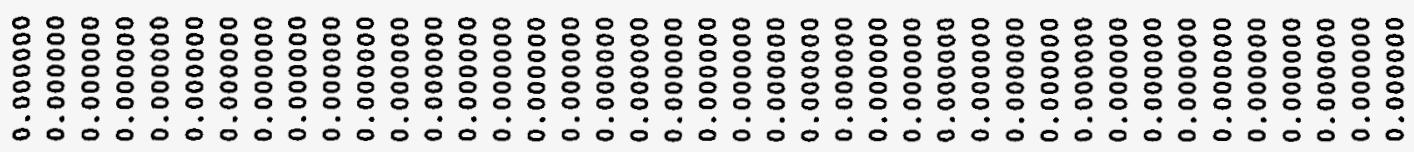

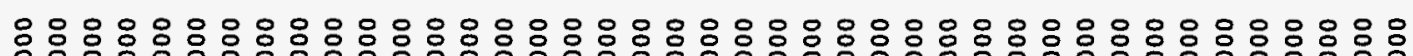

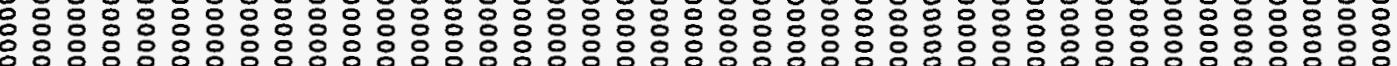

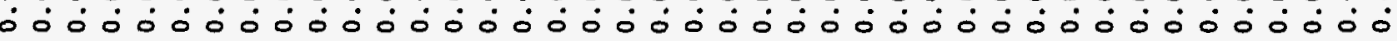

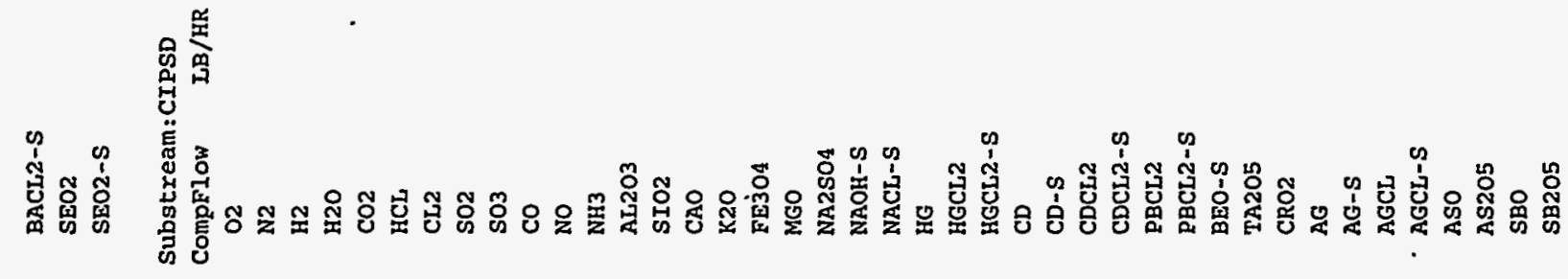


Table D-5. Simulation results for primary steams in the high-flow case.

\begin{tabular}{|c|c|c|c|c|c|c|c|c|}
\hline BACL2 & 0.000000 & 0.000000 & 0.000000 & 0.000000 & 0.000000 & 0.000000 & 0.000000 & 0.000000 \\
\hline BACL2-S & 0.000000 & 0.000000 & 0.000000 & 0.000000 & 0.000000 & 0.000000 & 0.000000 & 0.000000 \\
\hline SEO2 & 0.000000 & 0.000000 & 0.000000 & 0.000000 & 0.000000 & 0.000000 & 0.000000 & 0.000000 \\
\hline \multirow[t]{2}{*}{$\mathrm{SEO} 2-\mathrm{S}$} & 0.000000 & 0.000000 & 0.000000 & 0.000000 & 0.000000 & 0.000000 & 0.000000 & 0.000000 \\
\hline & SCCGAS & BHIN & BAGSOLID & QNCHOUT & SCRUBGAS & BLOWDOWN & REHOUT & PREFSOI \\
\hline \multicolumn{9}{|c|}{ Substream:CIASH } \\
\hline $\begin{array}{l}\text { CompFlow } \\
02\end{array}$ & & & & & & & & \\
\hline 02 & 0.000000 & 0.000000 & 0.000000 & 0.000000 & 0.000000 & 0.000000 & 0.000000 & 0.000000 \\
\hline N2 & 0.000000 & 0.000000 & 0.000000 & 0.000000 & 0.000000 & 0.000000 & 0.000000 & 0.000000 \\
\hline н2 & 0.000000 & 0.000000 & 0.000000 & 0.000000 & 0.000000 & 0.000000 & 0.000000 & 0.000000 \\
\hline H2O & 0.000000 & 0.000000 & 0.000000 & 0.000000 & 0.000000 & 0.000000 & 0.000000 & 0.000000 \\
\hline $\mathrm{CO} 2$ & 0.000000 & 0.000000 & 0.000000 & 0.000000 & 0.000000 & 0.000000 & 0.000000 & 0.000000 \\
\hline HCL & 0.000000 & 0.000000 & 0.000000 & 0.000000 & 0.000000 & 0.000000 & 0.000000 & 0.000000 \\
\hline CL2 & 0.000000 & 0.000000 & 0.000000 & 0.000000 & 0.000000 & 0.000000 & 0.000000 & 0.000000 \\
\hline $\mathrm{SO} 2$ & 0.000000 & 0.000000 & 0.000000 & 0.000000 & 0.000000 & 0.000000 & 0.000000 & 0.000000 \\
\hline $\mathrm{SO3}$ & 0.000000 & 0.000000 & 0.000000 & 0.000000 & 0.000000 & 0.000000 & 0.000000 & 0.000000 \\
\hline Co & 0.000000 & 0.000000 & 0.000000 & 0.000000 & 0.000000 & 0.000000 & 0.000000 & 0.000000 \\
\hline No & 0.000000 & 0.000000 & 0.000000 & 0.000000 & 0.000000 & 0.000000 & 0.000000 & 0.000000 \\
\hline $\mathrm{NH} 3$ & 0.000000 & 0.000000 & 0.000000 & 0.000000 & 0.000000 & 0.000000 & 0.000000 & 0.000000 \\
\hline AL2O3 & 93.710000 & 93.710000 & 93.280000 & 0.431100 & 0.086420 & 0.339500 & $8.642000 \mathrm{~B}+06$ & 0.064170 \\
\hline SIO2 & 65.600000 & 65.600000 & 65.300000 & 0.301800 & 0.060490 & 0.237700 & $6.0490008+06$ & 0.044920 \\
\hline CAO & 4.498000 & 4.498000 & 4.478000 & 0.020690 & 0.004147 & 0.016290 & $4.147000 \mathrm{E}+05$ & 0.003079 \\
\hline $\mathrm{K} 2 \mathrm{O}$ & 1.874000 & 1.874000 & 1.866000 & 0.008622 & 0.001740 & 0.006836 & $1.740000 \mathrm{E}+05$ & 0.001292 \\
\hline FE3O4 & 18.740000 & 18.740000 & 18.660000 & 0.086220 & 0.017280 & 0.067890 & $1.728000 \mathrm{~B}+06$ & 0.012830 \\
\hline MGO & 1.874000 & 1.874000 & 1.866000 & $0: 008622$ & 0.001708 & 0.006709 & $1.708000 \mathrm{E}+05$ & 0.001268 \\
\hline $\mathrm{NA2SO} 4$ & 0.000000 & 0.000000 & 0.000000 & 0.000000 & 0.000000 & 0.000000 & 0.000000 & 0.000000 \\
\hline NAOH-S & 0.000000 & 0.000000 & 0.000000 & 0.000000 & 0.000000 & 0.000000 & 0.000000 & 0.000000 \\
\hline NACL-S & 0.000000 & 0.000000 & 0.000000 & 0.000000 & 0.000000 & 0.000000 & 0.000000 & 0.000000 \\
\hline HG & 0.000000 & 0.000000 & 0.000000 & 0.000000 & 0.000000 & 0.000000 & 0.000000 & 0.000000 \\
\hline HGCL2 & 0.000000 & 0.000000 & 0.000000 & 0.000000 & 0.000000 & 0.000000 & 0.000000 & 0.000000 \\
\hline HGCL2-S & 0.000000 & 0.000000 & 0.000000 & 0.000000 & 0.000000 & 0.000000 & 0.000000 & 0.000000 \\
\hline $\mathrm{CD}$ & 0.000000 & 0.000000 & 0.000000 & 0.000000 & 0.000000 & 0.000000 & 0.000000 & 0.000000 \\
\hline$C D-S$ & 0.000000 & 0.000000 & 0.000000 & 0.000000 & 0.000000 & 0.000000 & 0.000000 & 0.000000 \\
\hline CDCL2 & 0.000000 & 0.000000 & 0.000000 & 0.000000 & 0.000000 & 0.000000 & 0.000000 & 0.000000 \\
\hline CDCL2-S & 0.000000 & 0.000000 & 0.000000 & 0.000000 & 0.000000 & 0.000000 & 0.000000 & 0.000000 \\
\hline PBCL2 & 0.000000 & 0.000000 & 0.000000 & 0.000000 & 0.000000 & 0.000000 & 0.000000 & 0.000000 \\
\hline PBCL2-S & 0.000000 & 0.000000 & 0.000000 & 0.000000 & 0.000000 & 0.000000 & 0.000000 & 0.000000 \\
\hline BEO-S & 21.480000 & 21.480000 & 21.380000 & 0.098810 & 0.019810 & 0.077830 & $1.981000 \mathrm{E}+06$ & 0.014710 \\
\hline TA205 & 0.268000 & 0.268000 & 0.266800 & 0.001233 & $2.522000 \mathrm{E}-04$ & $9.909000 \mathrm{E}-04$ & 25220.000000 & $1.873000 \mathrm{~B}-04$ \\
\hline $\mathrm{CRO} 2$ & 6.946000 & 6.946000 & 6.914000 & 0.031950 & 0.006404 & 0.025160 & $6.404000 \mathrm{E}+05$ & 0.004755 \\
\hline AG & 0.000000 & 0.000000 & 0.000000 & 0.000000 & 0.000000 & 0.000000 & 0.000000 & 0.000000 \\
\hline AG-S & 0.000000 & 0.000000 & 0.000000 & 0.000000 & 0.000000 & 0.000000 & 0.000000 & 0.000000 \\
\hline AGCL & 0.000000 & 0.000000 & 0.000000 & 0.000000 & 0.000000 & 0.000000 & 0.000000 & 0.000000 \\
\hline AGCL-S & 0.000000 & 0.000000 & 0.000000 & 0.000000 & 0.000000 & 0.000000 & 0.000000 & 0.000000 \\
\hline ASO & 0.000000 & 0.000000 & 0.000000 & 0.000000 & 0.000000 & 0.000000 & 0.000000 & 0.000000 \\
\hline
\end{tabular}




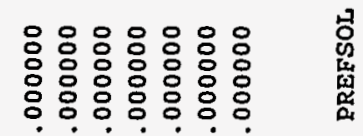

○ं $\dot{0}: \dot{0} 0 \dot{0}$

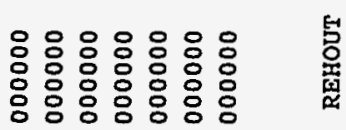

○ $\dot{0} \dot{0} \dot{0} \dot{0} \dot{0}$

mmem

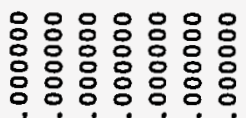

:

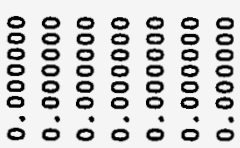

最

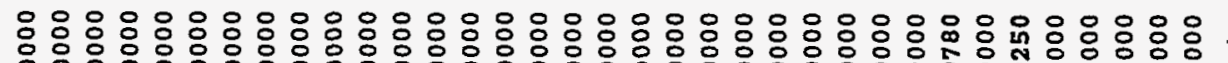

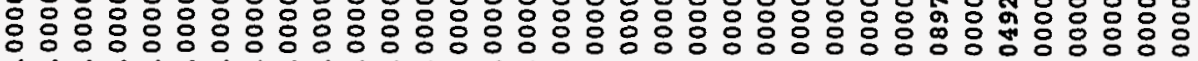

ó $\dot{0} \dot{0} \dot{0} \dot{0} \dot{0} \dot{0} \dot{0} \dot{0} \dot{0} \dot{0} \dot{0} \dot{0} \dot{0} \dot{0} \dot{0} \dot{0} \dot{0} \dot{0} \dot{0} \dot{0} \dot{0} \dot{0} \dot{0} \dot{0} \dot{0} 0 \dot{0} \dot{0} \dot{0} \dot{0} \dot{0}$

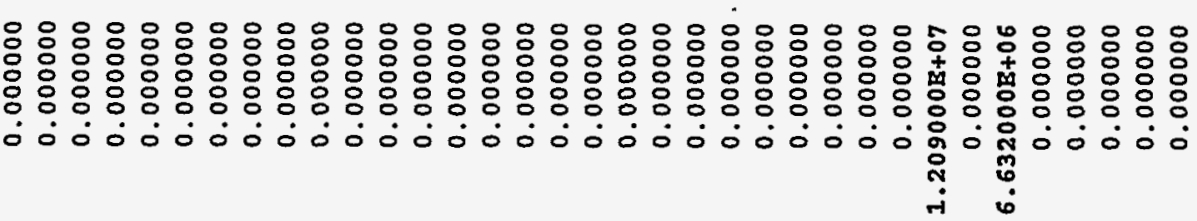

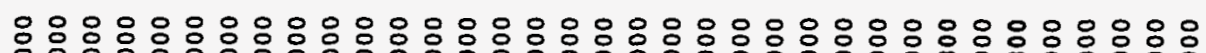

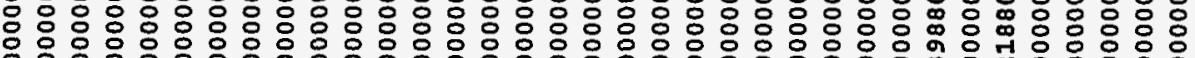

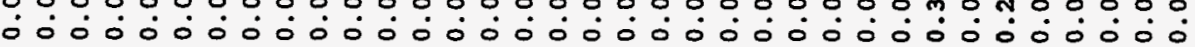

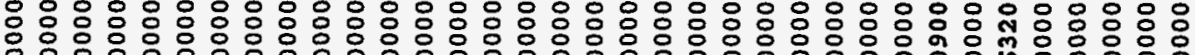

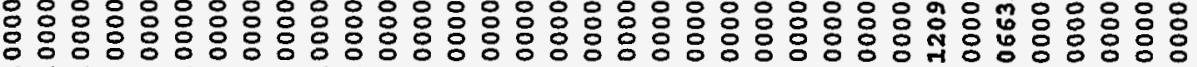

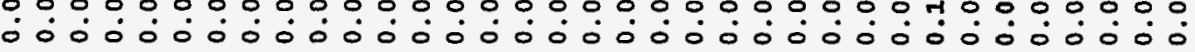

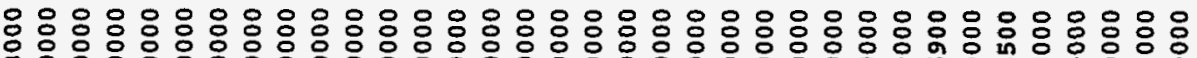

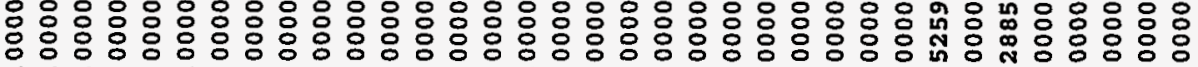

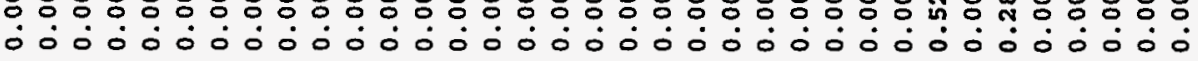

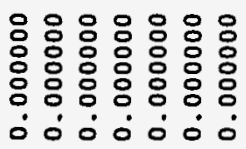

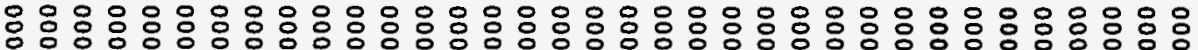

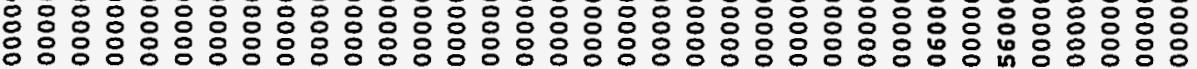

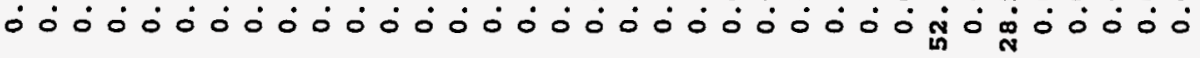

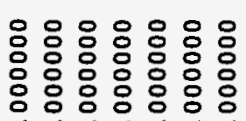

㽟

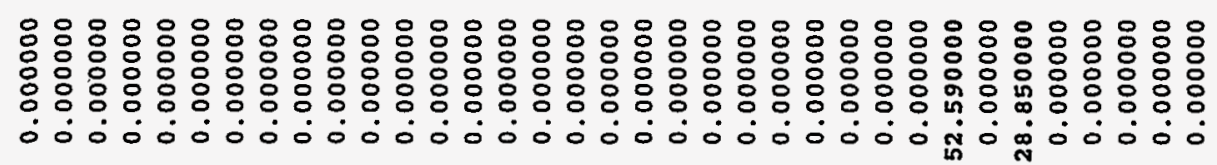

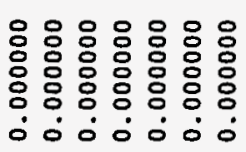

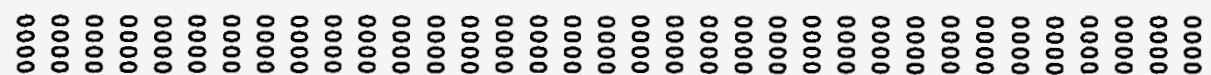

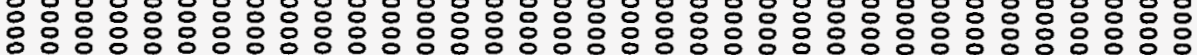
$\dot{0} \dot{0} \dot{0} \dot{0} \dot{0} \dot{0} \dot{0} \dot{0} \dot{0} \dot{0} \dot{0} \dot{0} \dot{0} \dot{0} \dot{0} \dot{0} \dot{0} \dot{0} \dot{0} \dot{0} \dot{0} \dot{0} \dot{0} \dot{0} \dot{0} \dot{0} \dot{0} \dot{0} \dot{0} \dot{0}$

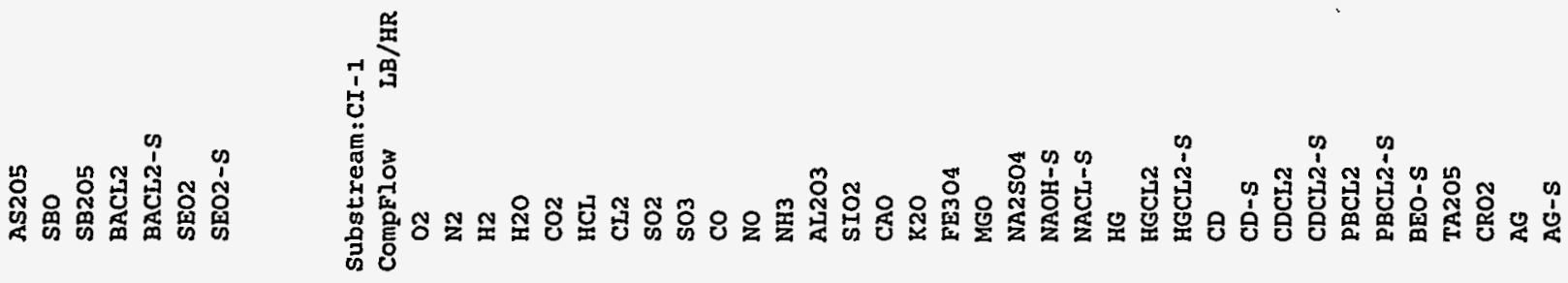

$\sum_{\infty}^{\infty}$ 


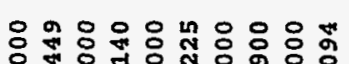

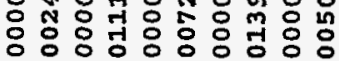
○ं $\dot{0} \dot{0} \dot{0} 0 \dot{0} 0 \dot{0}:$

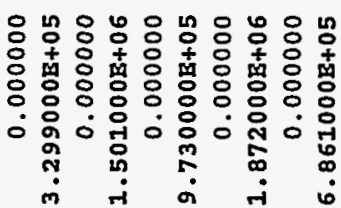

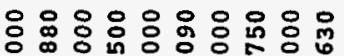

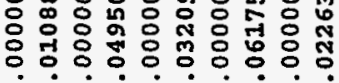

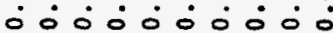

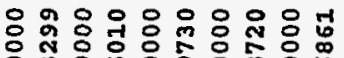

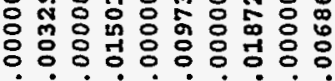
○ं0 :

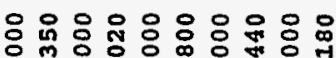

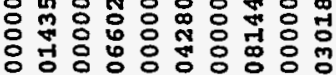

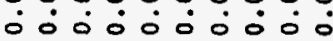

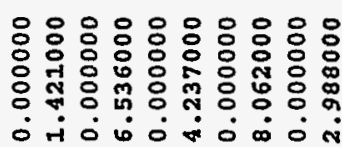

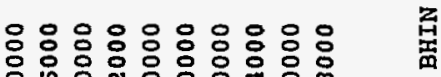

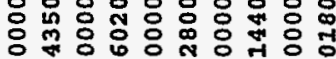

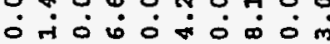

응ㅇㅇㅇㅇㅇㅇㅇㅇㅇㅇㅇㅇㅇㅠ 잉영영ㅇㅇㅇㅇㅇㅇㅇㅇㅇㅇㅇㅇㅇㅇㅇㅇㅇㅇ 0ं0் $\dot{0} 0 \dot{0} 0 \dot{0} 0 \dot{0}$

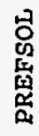

봉

줗

传

苛

đ્đ

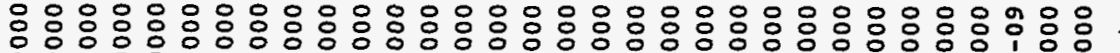

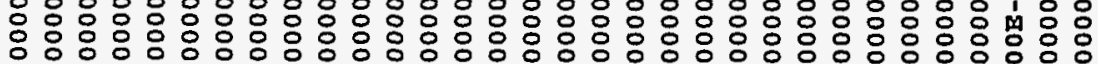
$\dot{0} \dot{0} \dot{0} \dot{0} \dot{0} \dot{0} \dot{0} \dot{0} \dot{0} \dot{0} \dot{0} \dot{0} \dot{0} \dot{0} \dot{0} \dot{0} \dot{0} \dot{0} \dot{0} \dot{0} \dot{0} \dot{0} \dot{0} \dot{0}$

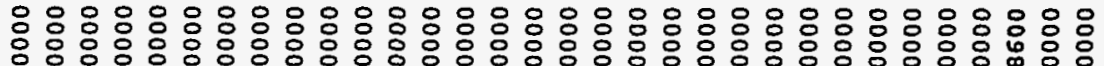

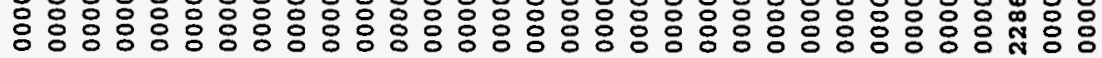
$\dot{0} \dot{0} \dot{0} \dot{0} \dot{0} \dot{0} \dot{0} \dot{0} \dot{0} \dot{0} \dot{0} \dot{0} \dot{0} \dot{0} \dot{0} \dot{0} \dot{0} \dot{0} \dot{0} \dot{0} \dot{0} \dot{0} \dot{0} \dot{0} \dot{0} \dot{0}$

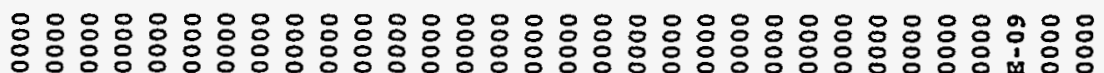

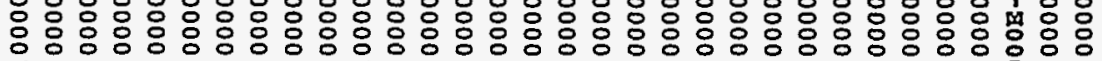

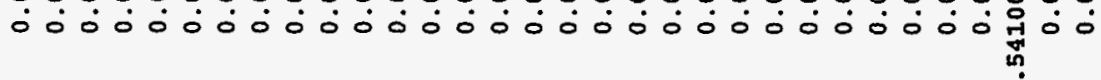

芯

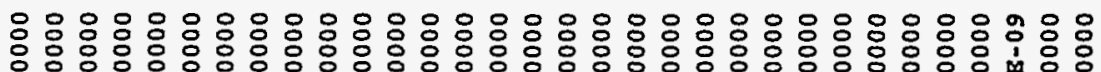

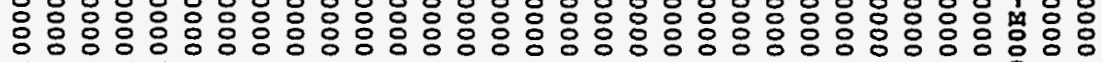

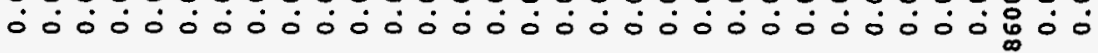

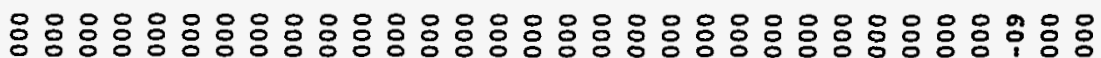

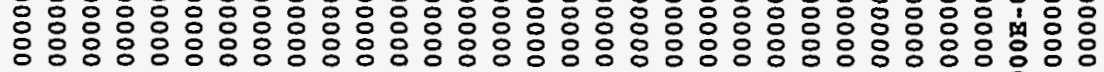
$\dot{0} \dot{0} \dot{0} \dot{0} \dot{0} \dot{0} \dot{0} \dot{0} \dot{0} \dot{0} \dot{0} \dot{0} \dot{0} \dot{0} \dot{0} \dot{0} \dot{0} \dot{0} \dot{0} \dot{0} \dot{0} \dot{0} \dot{0} \dot{0} \dot{0} \dot{0} \dot{0} \dot{0}$ i

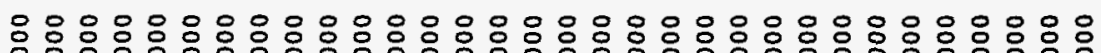

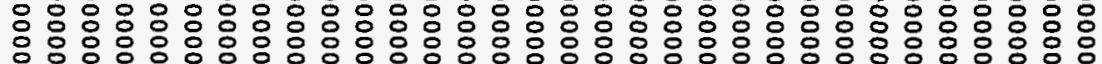
$\dot{0} \dot{0} \dot{0} \dot{0} \dot{0} \dot{0} \dot{0} \dot{0} \dot{0} \dot{0} \dot{0} \dot{0} \dot{0} \dot{0} \dot{0} \dot{0} \dot{0} \dot{0} \dot{0} \dot{0} \dot{0} \dot{0} \dot{0} \dot{0}$

惫

응융ㅇㅇㅇㅇㅇㅇㅇㅇㅇㅇㅇㅇㅇㅇㅇㅇㅇㅇㅇㅇㅇㅇㅇㅇㅇㅇㅇㅇㅇㅇㅇㅇㅇㅇㅇㅇㅇㅇㅇㅇㅇㅇㅇㅠ

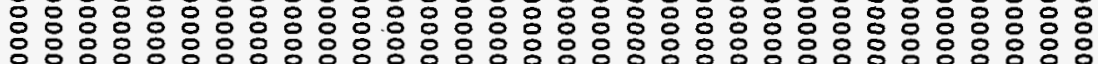
$\dot{0} \dot{0} \dot{0} \dot{0} \dot{0} \dot{0} \dot{0} \dot{0} \dot{0} \dot{0} \dot{0} \dot{0} \dot{0} \dot{0} \dot{0} \dot{0} \dot{0} \dot{0} \dot{0} \dot{0} \dot{0} \dot{0} \dot{0} \dot{0} \dot{0}$

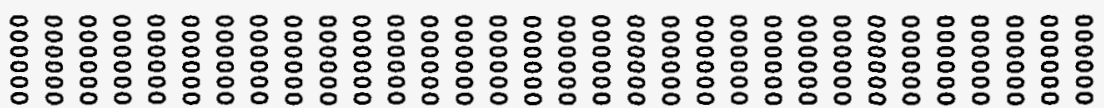

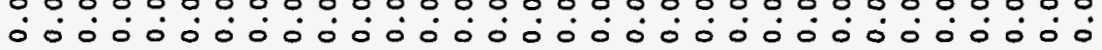

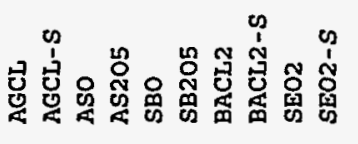

总

!n

$\stackrel{0}{\frac{\pi}{0}}$

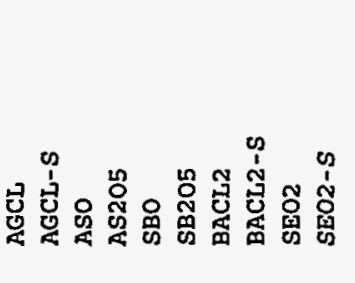

苋

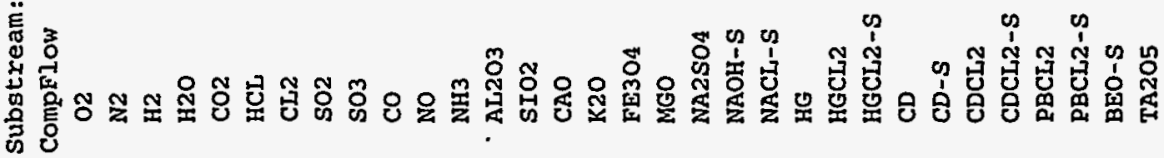


Mmmm!m!!

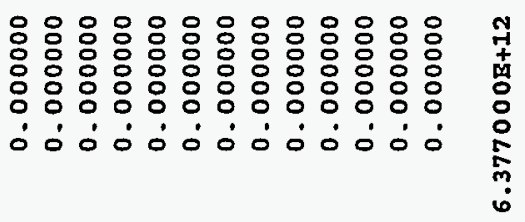

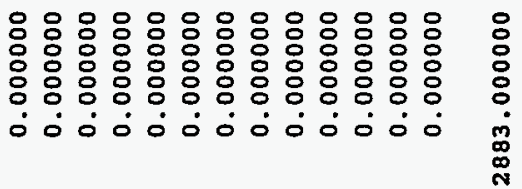

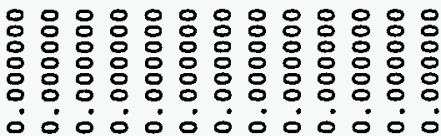

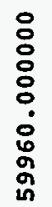

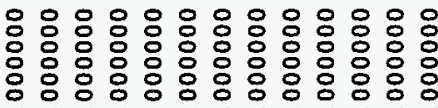

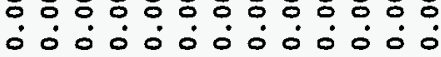

$\stackrel{7}{a}$

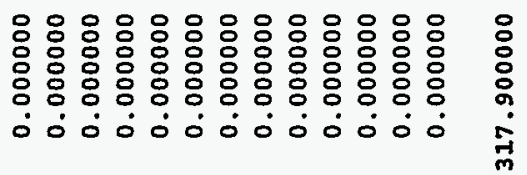

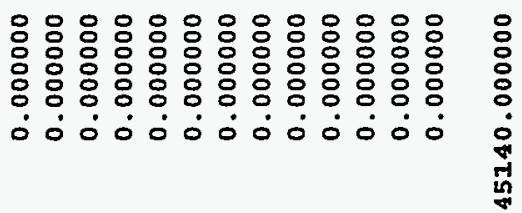

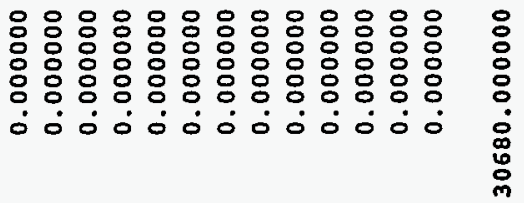

疍

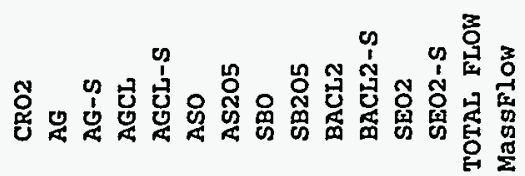




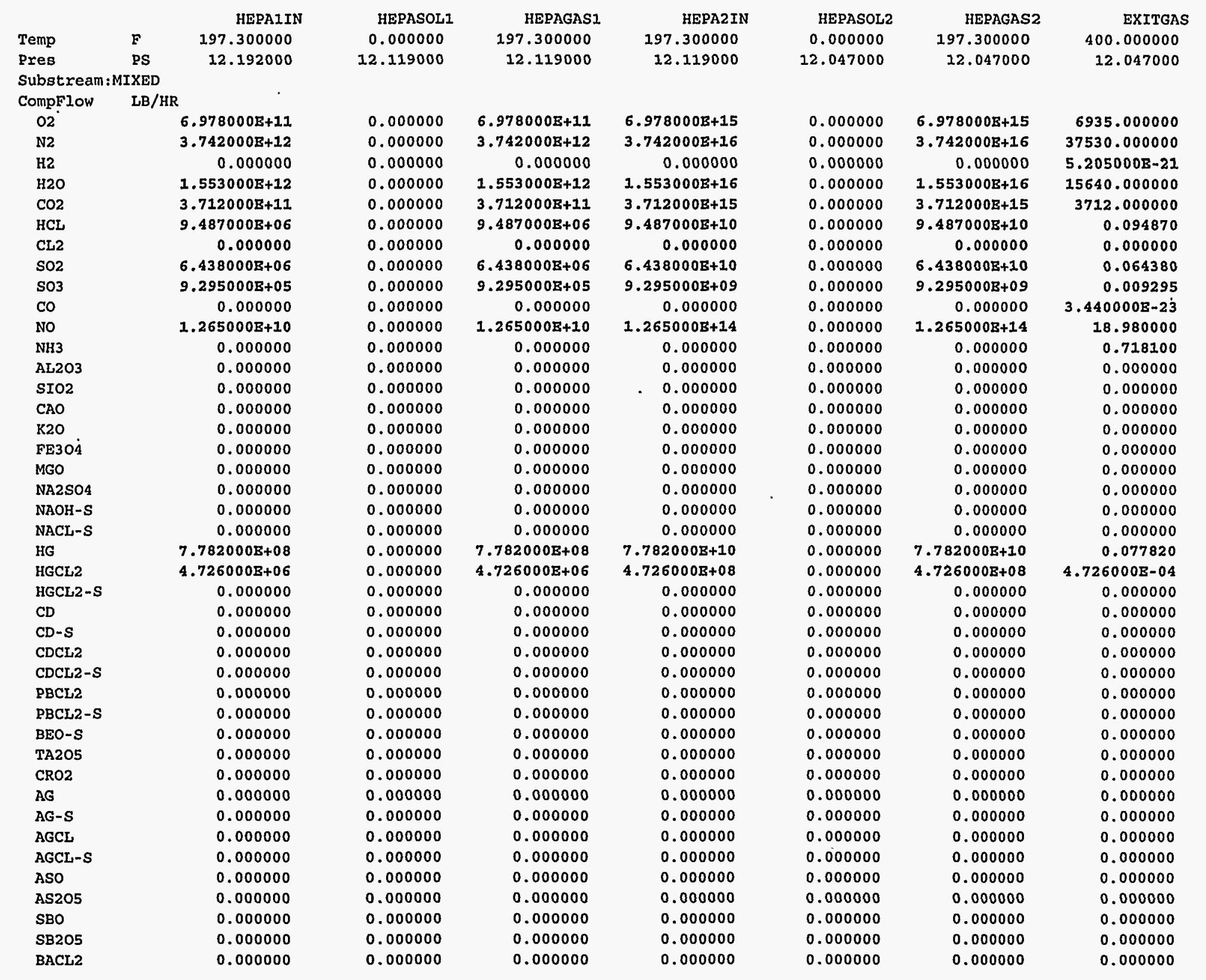




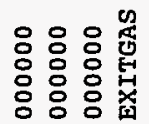
$\dot{0} \dot{0} \dot{0}$

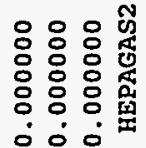

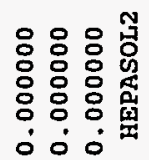

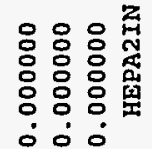

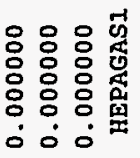

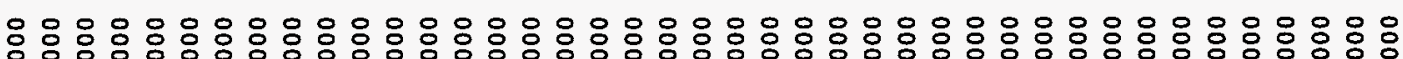

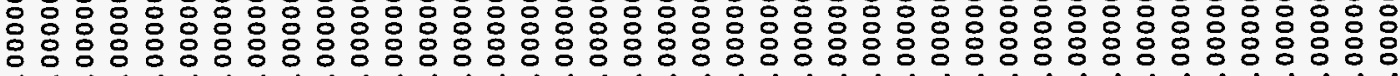
$\dot{0} \dot{0} \dot{0} \dot{0} \dot{0} \dot{0} \dot{0} \dot{0} \dot{0} \dot{0} \dot{0} \dot{0} \dot{0} \dot{0} \dot{0} \dot{0} \dot{0} \dot{0} \dot{0} \dot{0} \dot{0} \dot{0} \dot{0} \dot{0} \dot{0} \dot{0} \dot{0} \dot{0} \dot{0} \dot{0} \dot{0}$

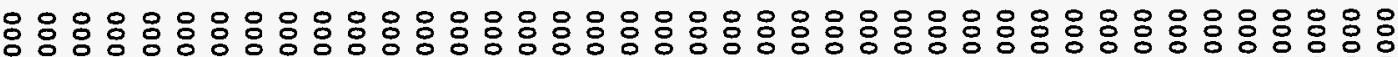

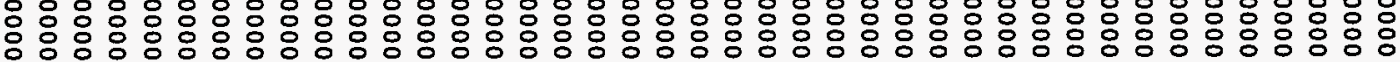
$\dot{0} \dot{0} \dot{0} \dot{0} \dot{0} \dot{0} \dot{0} \dot{0} \dot{0} \dot{0} \dot{0} \dot{0} \dot{0} \dot{0} \dot{0} \dot{0} \dot{0} \dot{0} \dot{0} \dot{0} \dot{0} \dot{0} \dot{0} \dot{0} \dot{0} \dot{0} \dot{0} \dot{0} \dot{0} \dot{0} \dot{0}$

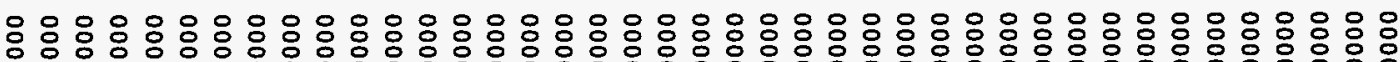

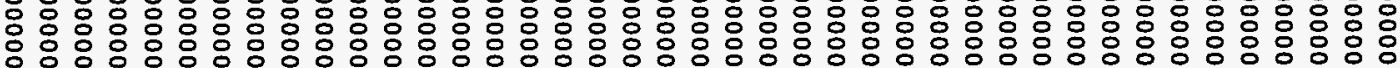
$\dot{0} \dot{0} \dot{0} \dot{0} \dot{0} \dot{0} \dot{0} \dot{0} \dot{0} \dot{0} \dot{0} \dot{0} \dot{0} \dot{0} \dot{0} \dot{0} \dot{0} \dot{0} \dot{0} \dot{0} \dot{0} \dot{0} \dot{0} \dot{0} \dot{0} \dot{0} \dot{0} \dot{0} \dot{0} \dot{0} \dot{0} \dot{0}$

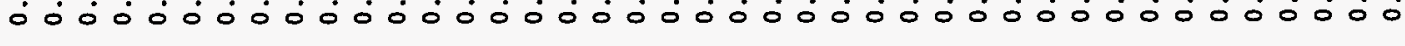

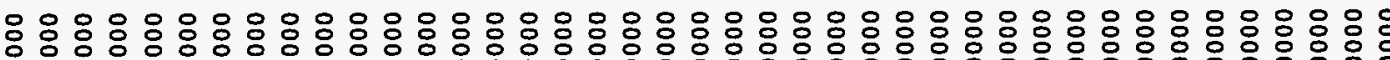

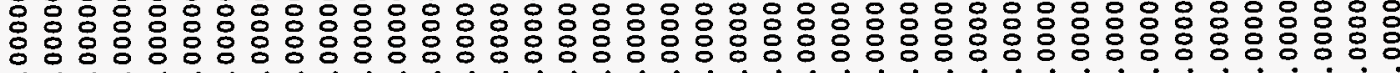
$\dot{0} \dot{0} \dot{0} \dot{0} \dot{0} \dot{0} \dot{0} \dot{0} \dot{0} \dot{0} \dot{0} \dot{0} \dot{0} \dot{0} \dot{0} \dot{0} \dot{0} \dot{0} \dot{0} \dot{0} \dot{0} \dot{0} \dot{0} \dot{0} \dot{0} \dot{0} \dot{0} \dot{0} \dot{0} \dot{0} \dot{0} \dot{0} \dot{0} \dot{0} \dot{0} \dot{0} \dot{0} \dot{0} \dot{0} \dot{0}$

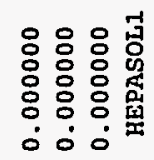

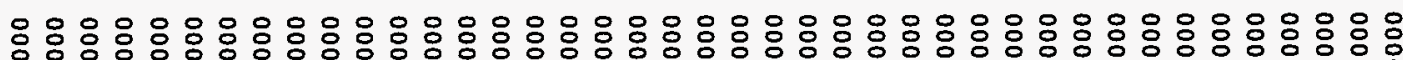

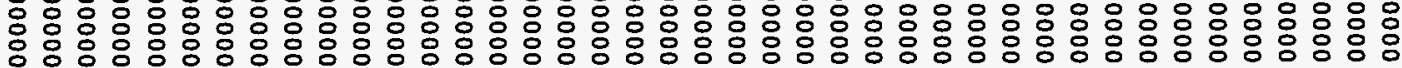
$\dot{0} \dot{0} \dot{0} \dot{0} \dot{0} \dot{0} \dot{0} \dot{0} \dot{0} \dot{0} \dot{0} \dot{0} \dot{0} \dot{0} \dot{0} \dot{0} \dot{0} \dot{0} \dot{0} \dot{0} \dot{0} \dot{0} \dot{0} \dot{0} \dot{0} \dot{0} \dot{0} \dot{0} \dot{0} \dot{0} \dot{0} 0 \dot{0} 0 \dot{0} 0$

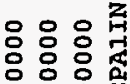

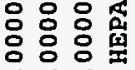 $\dot{0} \dot{0} \dot{0}$}

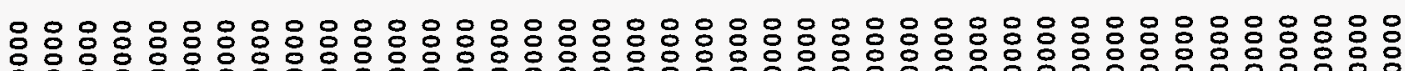

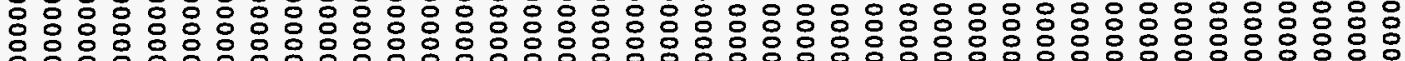

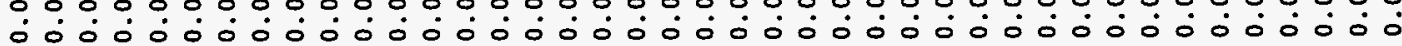<smiles></smiles>

员总

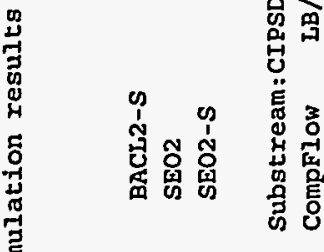




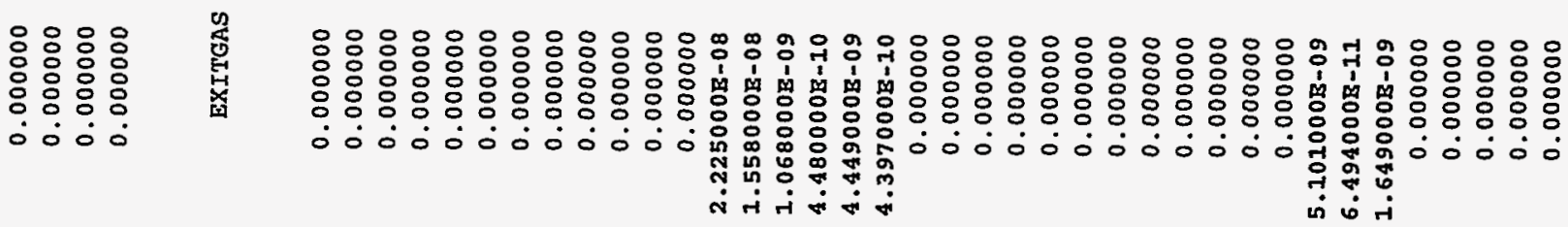

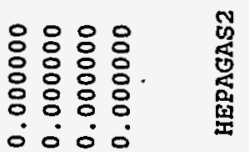

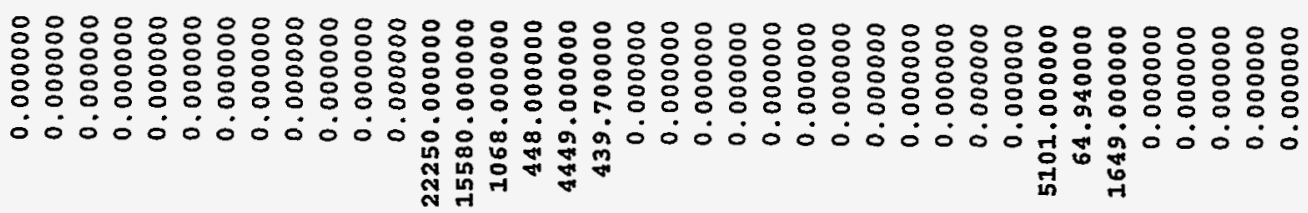

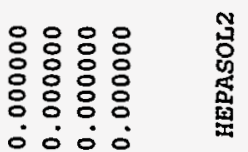

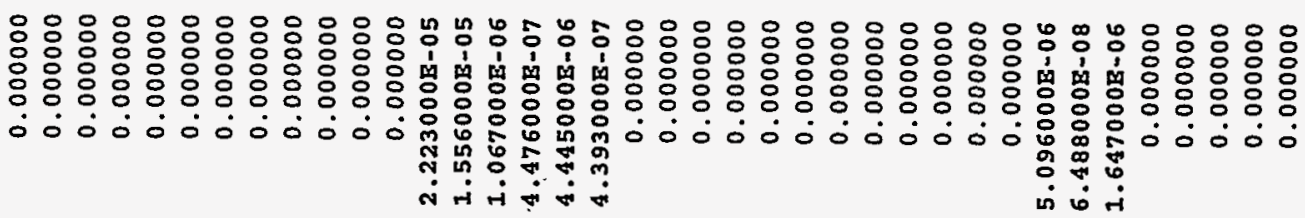

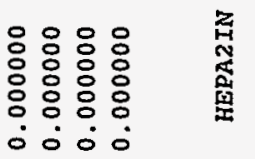

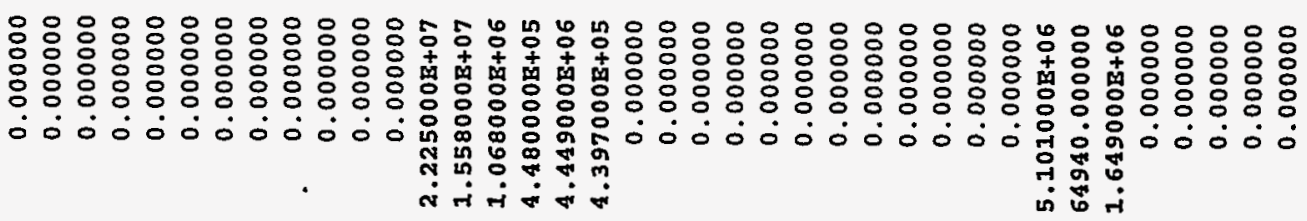

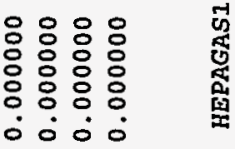

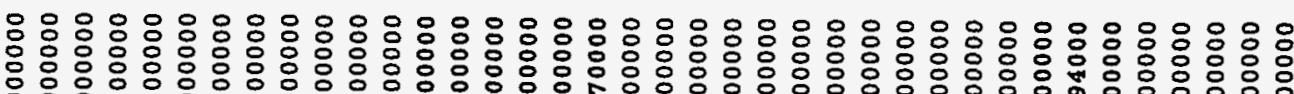

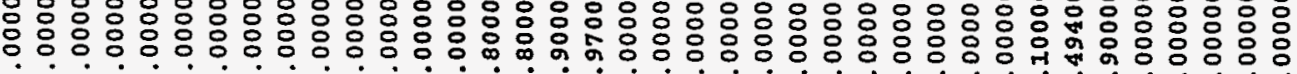

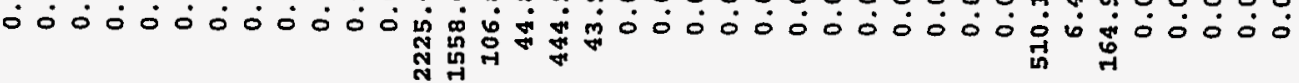

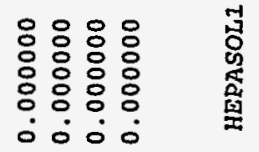

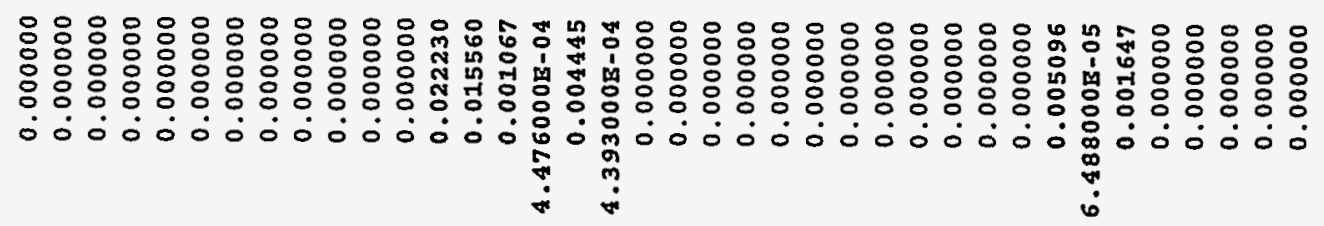

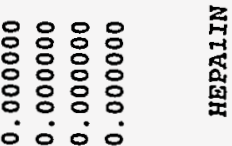

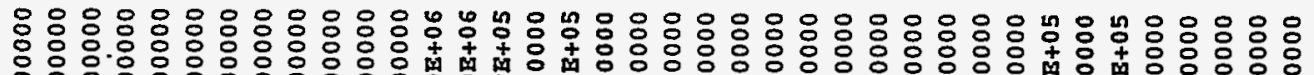

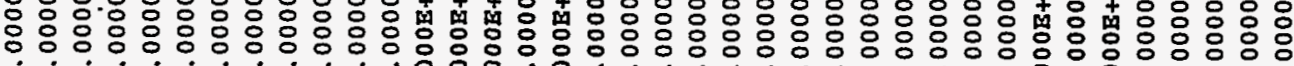

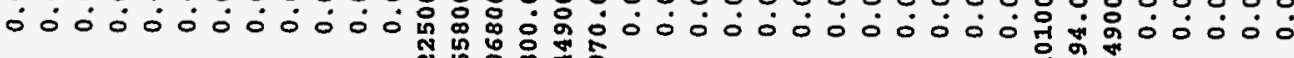

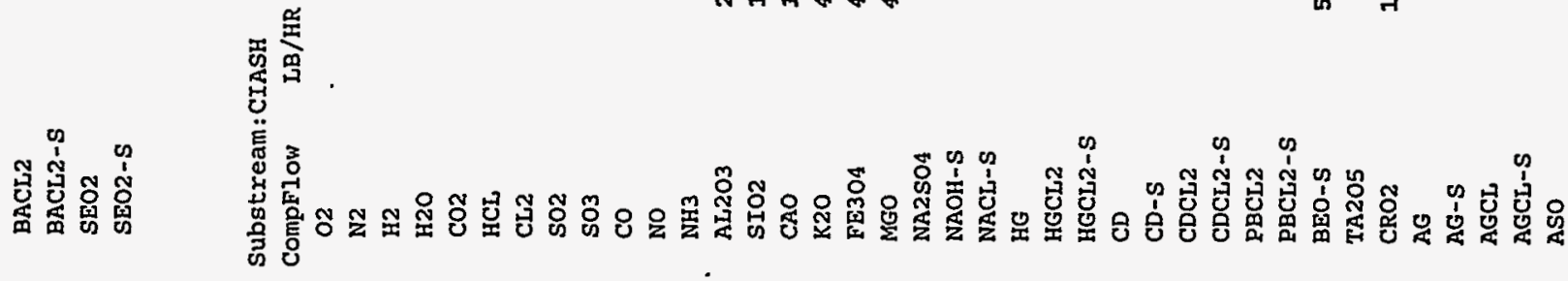
ஸे 
응응응응 ㅇํㅇㅇㅇㅇㅇㅇㅇำ 응ㅇㅇㅇㅇㅇㅇㅇㅇㅇㅇㅇㅇㅇㅇㅇ ○ं $\dot{0} \dot{0} \dot{0} 0$

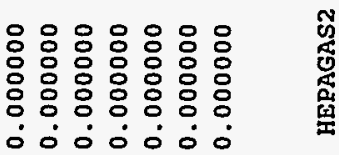

응용응응용응응 양응ㅇㅇㅇㅇㅇㅇㅇㅇㅇㅇㅇㅇㅇㅇㅇ ○ं $0 \dot{0} \dot{0} \dot{0} 0$

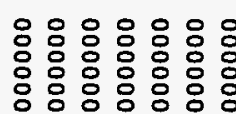

○ $\dot{0} \dot{0} \dot{0} \dot{0} \dot{0}$

응응융ㅇํㅇ융융영 응응응응ㅇㅇㅇㅇㅇㅇ융 $\dot{0} \dot{0} \dot{0} \dot{0} \dot{0} \dot{0}$

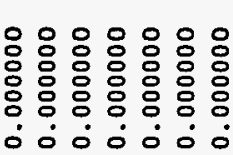

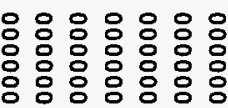
$\dot{0} \dot{0} \dot{0} \dot{0} \dot{0} \dot{0}$

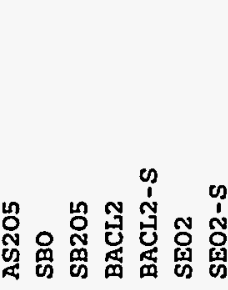

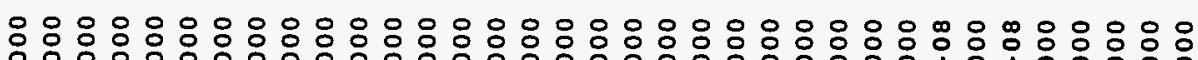

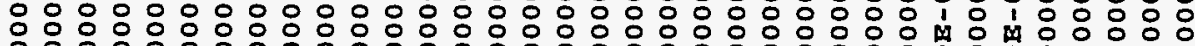

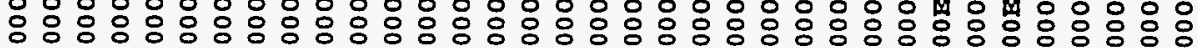

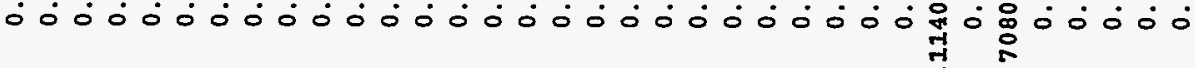

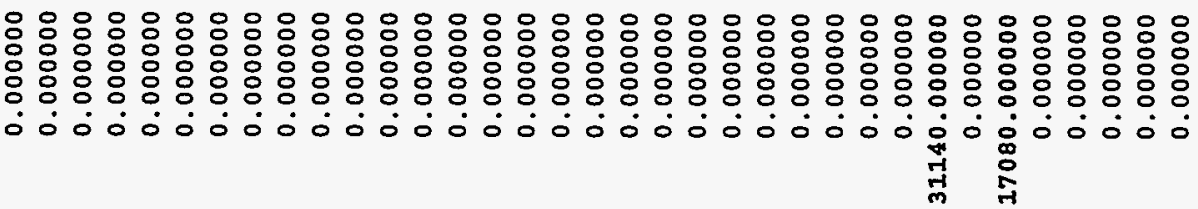

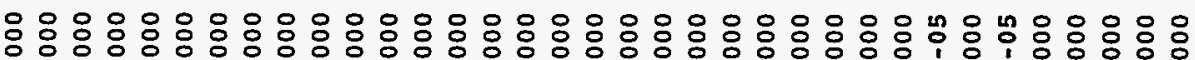

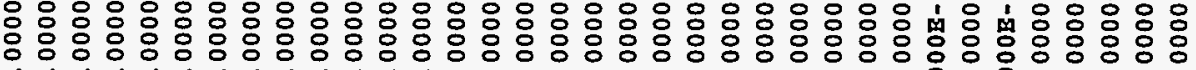

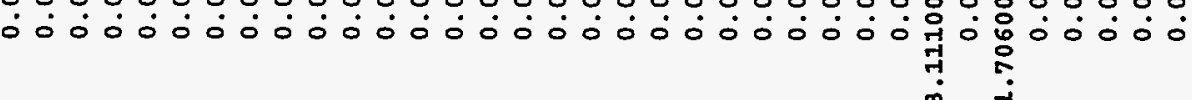

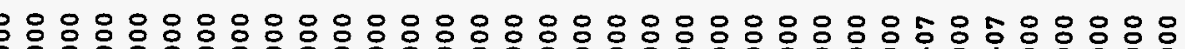

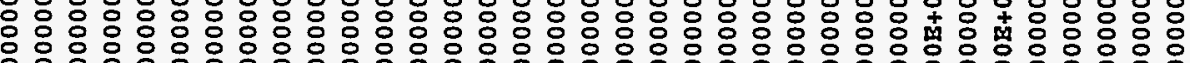

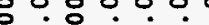

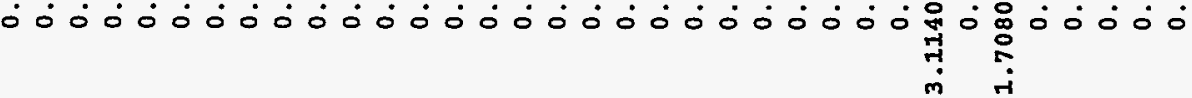

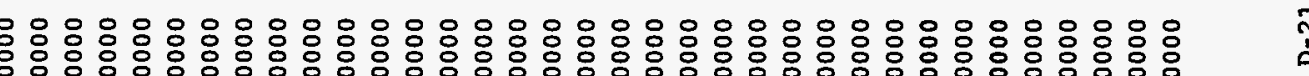

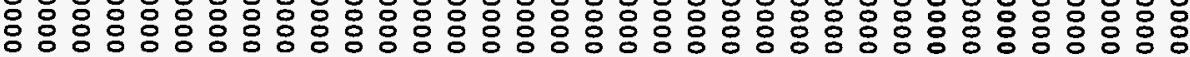

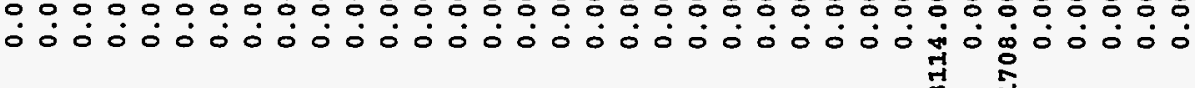

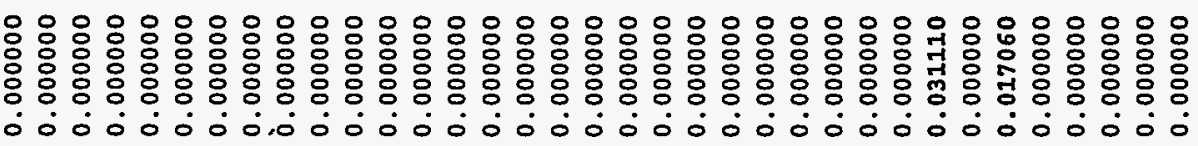

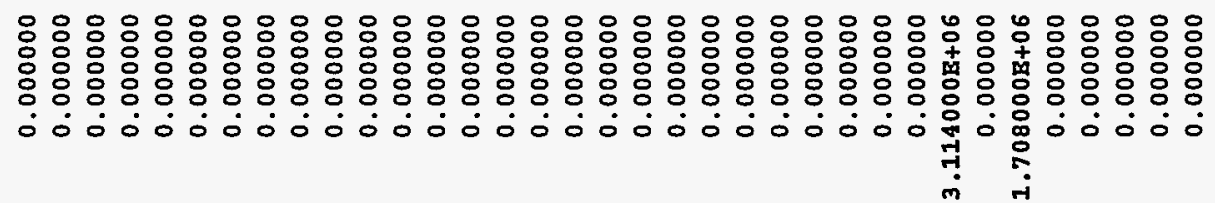
号总

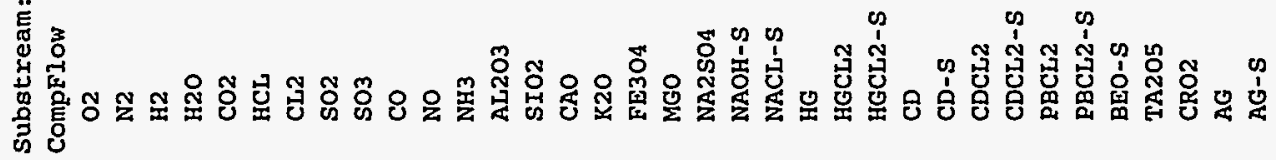




$\begin{array}{lrr}\text { AGCL } & 0.000000 & 0.000000 \\ \text { AGCL-S } & 84940.000000 & 8.486000 \mathrm{E}-04 \\ \text { ASO } & 0.000000 & 0.000000 \\ \text { AS2O5 } & 3.865000 \mathrm{~B}+05 & 0.003861 \\ \text { SBO } & 0.000000 & 0.000000 \\ \text { SB2O5 } & 2.506000 \mathrm{~B}+05 & 0.002503 \\ \text { BACL2 } & 0.000000 & 0.000000 \\ \text { BACL2-S } & 4.821000 \mathrm{~B}+05 & 0.004816 \\ \text { SEO2 } & 0.000000 & 0.000000 \\ \text { SEO2-S } & 1.767000 \mathrm{~B}+05 & 0.001765\end{array}$

Substream: $\mathrm{CI}-2$
CompFlow $\quad \mathrm{LB} / \mathrm{HR}$

$\begin{array}{ll}\text { O2 } & 0.000000 \\ \text { N2 } & 0.000000 \\ \text { H2 } & 0.000000 \\ \text { H2O } & 0.000000 \\ \text { CO2 } & 0.000000 \\ \text { HCL } & 0.000000 \\ \text { CL2 } & 0.000000 \\ \text { SO2 } & 0.000000 \\ \text { SO3 } & 0.000000 \\ \text { CO } & 0.000000 \\ \text { NO } & 0.000000 \\ \text { NH3 } & 0.000000 \\ \text { AL2O3 } & 0.000000 \\ \text { SIO2 } & 0.000000 \\ \text { CAO } & 0.000000 \\ \text { K2O } & 0.000000 \\ \text { FE3O4 } & 0.000000 \\ \text { MGO } & 0.000000 \\ \text { NA2SO4 } & 0.000000 \\ \text { NAOH-S } & 0.000000 \\ \text { NACL-S } & 0.000000 \\ \text { HG } & 0.000000 \\ \text { HGCL2 } & 0.000000 \\ \text { HGCL2-S } & 0.000000 \\ \text { CD } & 0.000000 \\ \text { CD-S } & 0.000000 \\ \text { CDCL2 } & 0.000000 \\ \text { CDCL2-S } & 0.000000 . \\ \text { PBCL2 } & 0.000000 \\ \text { PBCL2-S } & 0.058870 \\ \text { BEO-S } & 0.000000 \\ \text { TA2O5 } & 0.000000\end{array}$

\subsection{0}

84.940000

0.000000

386.500000

0.000000

250.600000

0.000000

482.100000

0.000000

176.700000

HEPASOL1

0.000000
0.000000
0.000000
0.000000
0.000000
0.000000
0.000000
0.000000
0.000000
0.000000
0.000000
0.000000
0.000000
0.000000
0.000000
0.000000
0.000000
0.000000
0.000000
0.000000
0.000000
0.000000
0.000000
0.000000
0.000000
0.000000
0.000000
0.000000
0.000000
$810005-10$
0.000000
0.000000

HEPAGAS 1

0.000000

0.000000

0.000000

0.000000

0.000000

0.000000

0.000000

0.000000

0.000000

0.000000

0.000000

0.000000

0.000000

0.000000

0.000000

0.000000

0.000000

0.000000

0.000000

0.000000

0.000000

0.000000

0.000000

0.000000

0.000000

0.000000

0.000000

0.000000

0.000000

5.887000B-05

0.000000

0.000000
0.000000

$8.494000 \mathrm{E}+05$

00000

$3.865000 \mathrm{~B}+06$

0.000000

$2.506000 \mathrm{~B}+06$

0.000000

$4.8210008+06$

0.000000
$1.767000 \mathrm{E}+06$
0.000000

$.486000 E-07$
0.000000

3.8610008-06

0.000000

2.5030008-06

0.000000

$4.816000 \mathrm{~B}-06$

0.000000

$1.765000 \mathrm{~B}-06$
0.000000

849.400000

0.000000

3865.000000

0.000000

2506.000000

4821.000000

0.000000

1767.000000
HEPA2IN

HEPASOL2

HEPAGAS2

0.000000

0.000000

0.000000

0.000000

0.000000

0.000000

0.000000

0.000000

0.000000

0.000000

0.000000

0.000000

0.000000

0.000000

0.000000

0.0000000

0.000000

0.000000

0.000000

0.000000

0.000000

0.000000

0.000000

0.000000

0.000000

0.000000

0.000000

0.000000

0.588700

0.000000

0.000000
0.000000

0.000000

0.000000

0.000000

0.000000

0.000000

0.000000

0.000000

0.000000

0.000000

0.000000

0.000000

0.000000

0.000000

0.000000

0.000000

0.000000

0.000000

0.000000

0.000000

0.000000

0.000000

0.000000

0.000000

0.000000

0.000000

0.000000

0.000000

0.000000

5. $881000 \mathrm{~B}-13$

0.000000

0.000000
0.000000

0.000000

0.000000

0.000000

0.000000

0.000000

0.000000

0.000000

0.000000

0.000000

0.000000

0.000000

0.000000

0.000000

0.000000

0.000000

0.000000

0.000000

0.000000

0.000000

0.000000

0.000000

0.000000

0.000000

0.000000

0.000000

0.000000

0.000000

0.000000

0.000000

0.000000
$5.887000 \mathrm{~B}-04$
0.000000

8.494000z-10

0.000000

$3.865000 \mathrm{~B}-09$

0.000000

2.506000E-09

0.000000

0.000000

1.767000E-09

EXITGAS

0.000000

0.000000

0.000000

0.000000

0.000000

0.000000

0.000000

0.000000

0.000000

0.000000

0.000000

0.000000

0.000000

0.000000

0.000000

0.000000

0.000000

0.000000

0.000000

0.000000

0.000000

0.000000

0.000000

0.000000

0.000000

0.000000

0.000000

0.000000

000000

$887000 \mathrm{~B}-16$

0.000000 

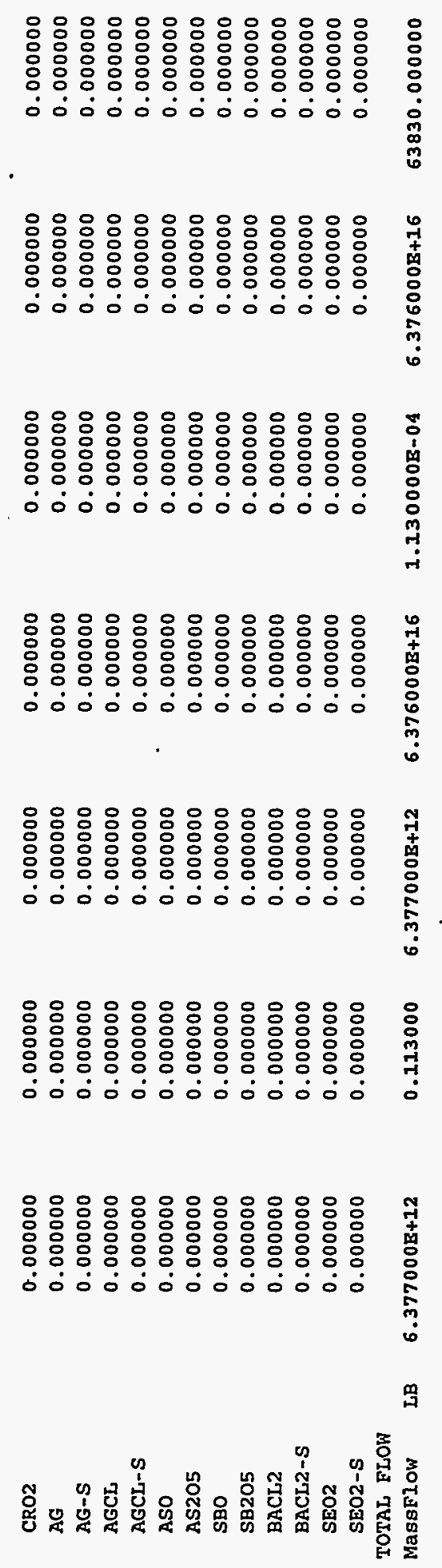


\begin{tabular}{|c|c|c|c|c|c|c|c|c|c|}
\hline & & SCCGAS & BHIN & BAGSOLID & QNCHOUT & SCRUBGAS & BLOWDOWN & REHOUT & PREFSOL \\
\hline Temp & F & 2200.000000 & 300.000000 & 0.000000 & 202.500000 & 181.500000 & 181.500000 & 195.000000 & 0.000000 \\
\hline Pres & PSI & 12.500000 & 12.500000 & 12.337000 & 12.337000 & 12.257000 & 12.330000 & 12.257000 & 12.184000 \\
\hline \multicolumn{10}{|c|}{ Substream : MIXED } \\
\hline CompFlow & $\mathrm{LB} / \mathrm{HR}$ & & & & & & & & \\
\hline 02 & & 2523.000000 & 2520.000000 & 0.000000 & 2520.000000 & 3789.000000 & 0.442900 & $3.9360008+11$ & 0.000000 \\
\hline N2 & & 736.400000 & 736.400000 & 0.000000 & 736.400000 & 4961.000000 & 0.462700 & $5.4440008+11$ & 0.000000 \\
\hline н2 & & 0.000000 & 0.000000 & 0.000000 & 0.000000 & 0.000000 & 0.000000 & 0.000000 & 0.000000 \\
\hline $\mathrm{H} 2 \mathrm{O}$ & & 4736.000000 & 13870.000000 & 0.000000 & 14640.000000 & 14000.000000 & 5423.000000 & $1.402000 \mathrm{~B}+12$ & 0.000000 \\
\hline $\mathrm{CO} 2$ & & 6941.000000 & 6941.000000 & 0.000000 & 6941.000000 & 6939.000000 & 2.052000 & $6.9390008+11$ & 0.000000 \\
\hline HCL & & 479.200000 & 477.300000 & 0.000000 & 477.300000 & 0.475400 & $6.563000 \mathrm{~B}-04$ & $4.754000 \mathrm{~B}+07$ & 0.000000 \\
\hline $\mathrm{CL2}$ & & 3.728000 & 1.753000 & 0.000000 & 1.753000 & 0.000000 & 0.000000 & 0.000000 & 0.000000 \\
\hline $\mathrm{SO} 2$ & & 33.680000 & 31.580000 & 0.000000 & 31.580000 & 0.315400 & $1.417000 \mathrm{~B}=04$ & $3.154000 \mathrm{~B}+07$ & 0.000000 \\
\hline $\mathrm{SO} 3$ & & 0.000000 & 2.625000 & 0.000000 & 2.625000 & 0.000000 & 0.000000 & 0.000000 & 0.000000 \\
\hline $\mathrm{CO}$ & & 0.147300 & 0.000000 & 0.000000 & 0.000000 & 0.000000 & 0.000000 & 0.000000 & 0.000000 \\
\hline No & & 63.100000 & 63.100000 & 0.000000 & 63.100000 & 63.100000 & $8.859000 \mathrm{E}-05$ & $6.3100008+09$ & 0.000000 \\
\hline NH3 & & 0.000000 & 0.000000 & 0.000000 & 0.000000 & 0.000000 & 0.000000 & 0.000000 & 0.000000 \\
\hline AL2O3 & & 0.000000 & 0.000000 & 0.000000 & 0.000000 & 0.000000 & 0.000000 & 0.000000 & 0.000000 \\
\hline SIO2 & & 0.000000 & 0.000000 & 0.000000 & 0.000000 & 0.000000 & 0.000000 & 0.000000 & 0.000000 \\
\hline CAO & & 0.000000 & 0.000000 & 0.000000 & 0.000000 & 0.000000 & 0.000000 & 0.000000 & 0.000000 \\
\hline $\mathrm{k} 20$ & & 0.000000 & 0.000000 & 0.000000 & 0.000000 & 0.000000 & 0.000000 & 0.000000 & 0.000000 \\
\hline FE304 & & 0.000000 & 0.000000 & 0.000000 & 0.000000 & 0.000000 & 0.000000 & 0.000000 & 0.000000 \\
\hline MGO & & 0.000000 & 0.000000 & 0.000000 & 0.000000 & 0.000000 & 0.000000 & 0.000000 & 0.000000 \\
\hline $\mathrm{NA2SO} 4$ & & 0.000000 & 0.000000 & 0.000000 & 0.000000 & 0.000000 & 0.000000 & 0.000000 & 0.000000 \\
\hline NAOH-S & & 0.000000 & 0.000000 & 0.000000 & 0.000000 & 0.000000 & 0.000000 & 0.000000 & 0.000000 \\
\hline NACL-S & & 0.000000 & 0.000000 & 0.000000 & 0.000000 & 0.000000 & 0.000000 & 0.000000 & 0.000000 \\
\hline HG & & 10.740000 & 0.000000 & 0.000000 & 0.000000 & 0.000000 & 0.000000 & 0.000000 & 0.000000 \\
\hline HGCL2 & & 0.000000 & 14.530000 & 0.000000 & 8.901000 & 0.000000 & 0.000000 & $4.270000 \mathrm{~B}+06$ & 0.000000 \\
\hline HGCL2-S & & 0.000000 & 0.000000 & 0.000000 & 0.000000 & 0.000000 & 0.000000 & 0.000000 & 0.000000 \\
\hline $\mathrm{CD}$ & & 0.000000 & 0.000000 & 0.000000 & 0.000000 & 0.000000 & 0.000000 & 0.000000 & 0.000000 \\
\hline$C D-S$ & & 0.000000 & 0.000000 & 0.000000 & 0.000000 & 0.000000 & 0.000000 & 0.000000 & 0.000000 \\
\hline CDCL2 & & 52.650000 & 0.000000 & 0.000000 & 0.000000 & 0.000000 & 0.000000 & 0.000000 & 0.000000 \\
\hline CDCL2-S & & 0.000000 & 0.000000 & 0.000000 & 0.000000 & 0.000000 & 0.000000 & 0.000000 & 0.000000 \\
\hline PBCL2 & & 28.800000 & 0.000000 & 0.000000 & 0.000000 & 0.000000 & 0.000000 & 0.000000 & 0.000000 \\
\hline PBCL2-S & & 0.000000 & 0.000000 & 0.000000 & 0.000000 & 0.000000 & 0.000000 & 0.000000 & 0.000000 \\
\hline BEO-S & & 0.000000 & 0.000000 & 0.000000 & 0.000000 & 0.000000 & 0.000000 & 0.000000 & 0.000000 \\
\hline TA205 & & 0.000000 & 0.000000 & 0.000000 & 0.000000 & 0.000000 & 0.000000 & 0.000000 & 0.000000 \\
\hline $\mathrm{CRO} 2$ & & 0.000000 & 0.000000 & 0.000000 & 0.000000 & 0.000000 & 0.000000 & 0.000000 & 0.000000 \\
\hline AG & & 0.000000 & 0.000000 & 0.000000 & 0.000000 & 0.000000 & 0.000000 & 0.000000 & 0.000000 \\
\hline $\mathbf{A G}-\mathrm{S}$ & & 0.000000 & 0.000000 & 0.000000 & 0.000000 & 0.000000 & 0.000000 & 0.000000 & 0.000000 \\
\hline AGCL & & $1: 432000$ & 0.000000 & 0.000000 & 0.000000 & 0.000000 & 0.000000 & 0.000000 & 0.000000 \\
\hline AGCL-S & & 0.000000 & 0.000000 & 0.000000 & 0.000000 & 0.000000 & 0.000000 & 0.000000 & 0.000000 \\
\hline ASO & & 5.210000 & 0.000000 & 0.000000 & 0.000000 & 0.000000 & 0.000000 & 0.000000 & 0.000000 \\
\hline AS205 & & 0.000000 & 0.000000 & 0.000000 & 0.000000 & 0.000000 & 0.000000 & 0.000000 & 0.000000 \\
\hline SBO & & 3.643000 & 0.000000 & 0.000000 & 0.000000 & 0.000000 & 0.000000 & 0.000000 & 0.000000 \\
\hline SB205 & & 0.000000 & 0.000000 & 0.000000 & 0.000000 & 0.000000 & 0.000000 & 0.000000 & 0.000000 \\
\hline BACL2 & & 8.145000 & 0.000000 & 0.000000 & 0.000000 & 0.000000 & 0.000000 & 0.000000 & 0.000000 \\
\hline
\end{tabular}




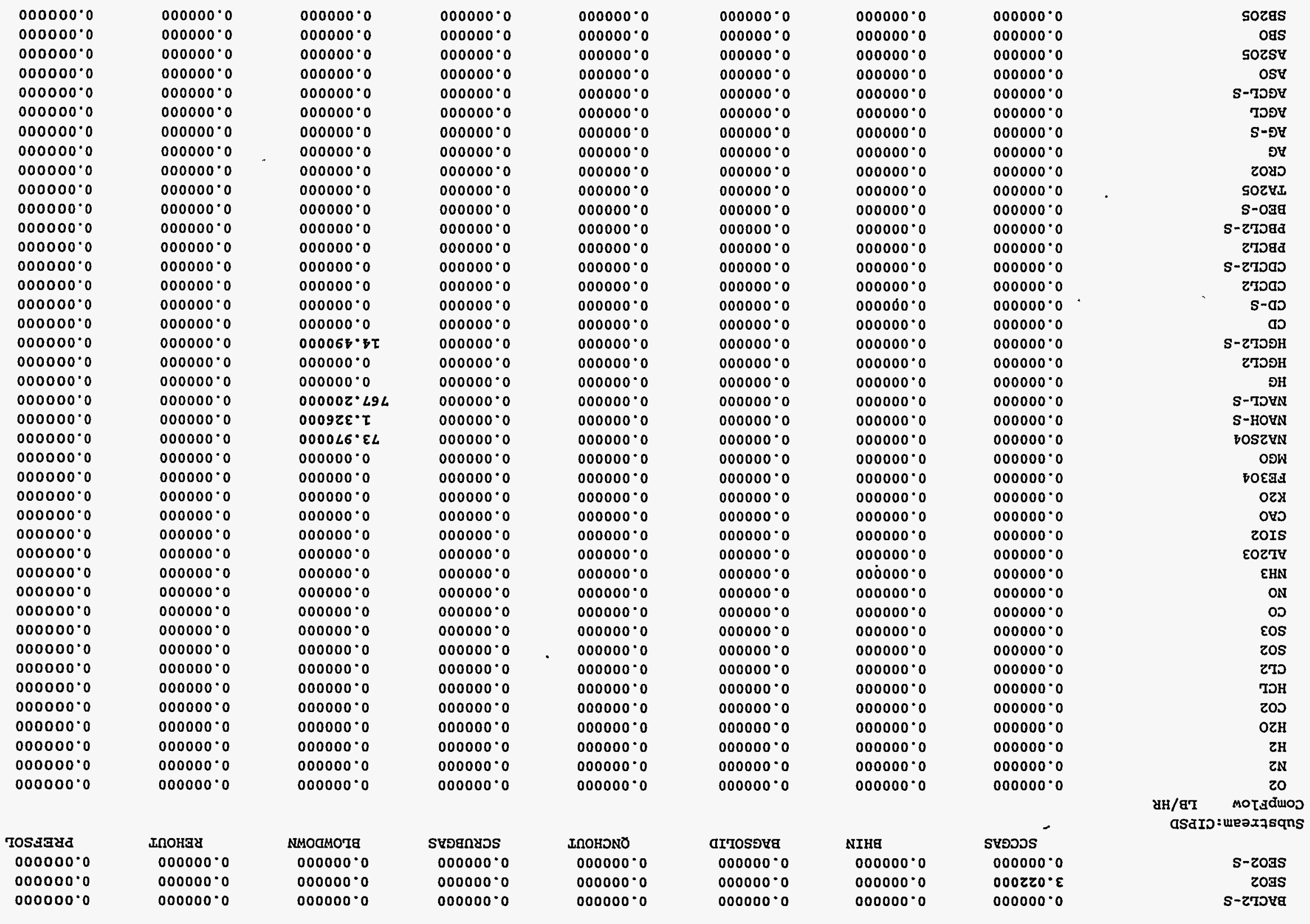


Table D-6. Simulation results for primary streams in low-flow case.

BACL2
BACL2-S
SEO2

SEO2-S

\subsection{0 \\ 0.000000 \\ 0.000000}

0.000000

SCCGAS

Substream: CIASH

\section{CompFlow LB/HR}

\begin{tabular}{lr} 
O2 & 0.000000 \\
N2 & 0.000000 \\
H2 & 0.000000 \\
H2O & 0.000000 \\
CO2 & 0.000000 \\
HCL & 0.000000 \\
CL2 & 0.000000 \\
SO2 & 0.000000 \\
SO3 & 0.000000 \\
CO & 0.000000 \\
NO & 0.000000 \\
NH3 & 0.000000 \\
AL2O3 & 93.710000 \\
SIO2 & 65.600000 \\
CAO & 4.498000 \\
K2O & 1.874000 \\
FE3O4 & 18.740000 \\
MGO & 1.874000 \\
NA2SO4 & 0.000000 \\
NAOH-S & 0.000000 \\
NACL-S & 0.000000 \\
HG & 0.000000 \\
HGCL2 & 0.000000 \\
HGCL2-S & 0.000000 \\
CD & 0.000000 \\
CD-S & 0.000000 \\
CDCL2 & 0.000000 \\
CDCL2-S & 0.000000 \\
PBCL2 & 0.000000 \\
PBCL2-S & 0.000000 \\
BEO-S & 21.480000 \\
TA2O5 & 0.268000 \\
CRO2 & 6.946000 \\
AG & 0.000000 \\
AG-S & 0.000000 \\
AGCL & 0.000000 \\
AGCL-S & 0.000000 \\
ASO & 0.000000 \\
& \\
\hline
\end{tabular}

$\begin{array}{ll}0.000000 & 0.000000 \\ 0.000000 & 0.000000 \\ 0.000000 & 0.000000 \\ 0.000000 & 0.000000\end{array}$

0.000000

0.000000

0.000000

0.000000

0.000000

0.000000

0.000000

0.000000

0.000000

0.000000

0.000000

93.710000

65.600000

4.498000
1.874000

740000

18.740000

1.874000
0.000000

0.000000

0.000000

0.000000

0.000000

0.000000

0.000000

0.000000

0.000000

0.000000

0.000000

0.000000

21.480000

0.268000

6.946000

0.000000

0.000000

0.000000

0.000000

0.000000
BAGSOLID

0.000000

0.000000

0.000000

0.000000

0.000000

0.000000

0.000000

0.000000

0.000000

0.000000

0.000000

0.000000

93.110000

65.180000

4.470000

1.862000

18.620000

1.862000

0.000000

0.000000

0.000000

0.000000

0.000000

0.000000

0.000000

0.000000

0.000000

0.000000

0.000000

0.000000

21.340000

0.266300

6.902000

0.000000

0.000000

0.000000

0.000000

0.000000

$\begin{array}{ll}0.000000 & 0.000000 \\ 0.000000 & 0.000000 \\ 0.000000 & 0.000000\end{array}$

0.000000

QNCHOUT

0.000000

0.000000

0.000000

0.000000

0.000000

0.000000

0.000000

0.000000

0.000000

0.000000

0.000000

0.000000

0.599800

0.419800

0.028790

0.012000

0.120000

0.012000

0.000000

0.000000

0.000000

0.000000

0.000000

0.000000

0.000000

0.000000

0.000000

0.000000

0.000000

0.000000

0.137500

0.001715

0.044460

0.000000

0.000000

0.000000

0.000000

0.000000
SCRUBGAS

0.000000

0.000000

0.000000

0.000000

0.000000

0.000000

0.000000

0.000000

0.000000

0.000000

0.000000

0.000000

0.128900

0.090210

0.006186

0.002578

0.025780

0.002578

0.000000

0.000000

0.000000

0.000000

0.000000

0.000000

0.000000

0.000000

0.000000

0.000000

0.000000

0.000000

0.029540

$3.686000 \mathrm{~B}-0$

0.009552

0.000000

0.000000

0.000000

0.000000

0.000000
0.000000
0.000000
0.000000

0.000000

BLOWDOWN

0.000000

0.000000

0.000000

0.000000

0.000000

0.000000

0.000000

0.000000

0.000000

0.000000

0.000000

0.470900

0.329600

0.022600

0.009417

0.094170

0.009417

0.000000

0.000000

0.000000

0.000000

0.000000

0.000000

0.000000

0.000000

0.000000

0.000000

0.000000

0.000000

0.107900

0.001347

0.034900

0.000000

0.000000

0.000000

0.000000

0.000000
0.000000
0.000000
0.000000

0.000000

REHOUT

0.000000

0.000000

0.000000

0.000000

0.000000

0.000000

0.000000

0.000000

0.000000

0.000000

0.000000

0.000000

$1.289000 \mathrm{~B}+07$

$9.021000 \mathrm{~B}+06$

$6.186000 \mathrm{E}+05$

$2.578000 \mathrm{~B}+06$

$2.578000 \mathrm{~B}+05$

0.000000

0.000000

0.000000

0.000000

0.000000

0.000000

0.000000

0.000000

0.000000

0.000000

0.000000

0.000000

$2.9540008+06$

36860.000000

$.552000 \mathrm{~s}+05$

0.000000

0.000000

0.000000

0.000000

0.000000

0.000000

0.000000

0.000000

0.000000

PREFSOL

0.000000

.000000

0.000000

0.000000

0.000000

0.000000

0.000000

0.000000

0.000000

0.000000

.000000

0.000000

0.066980

0.004593

0.001914

0.019140

0.001914

0.000000

0.000000

0.000000

0.000000

0.000000 
융융융융융

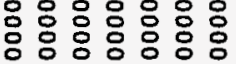

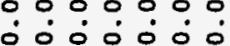

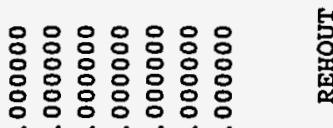

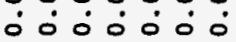

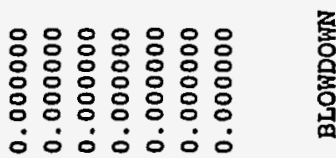

$\therefore:::: \circ:$

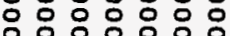

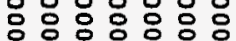

:

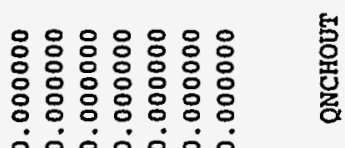

突

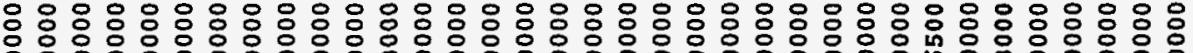

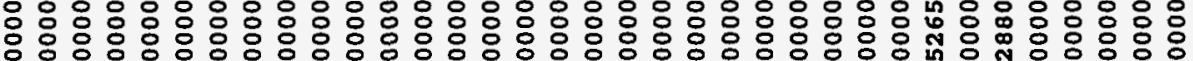

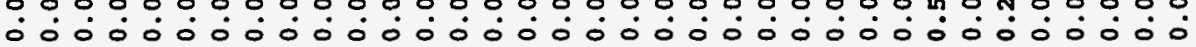

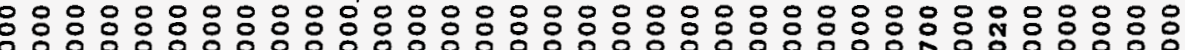

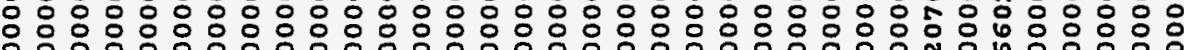
:

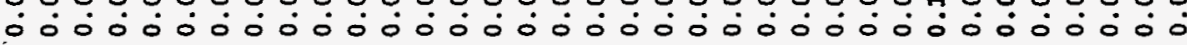

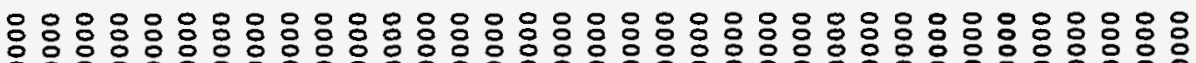

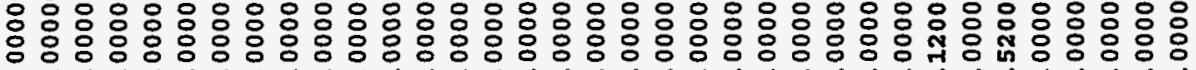

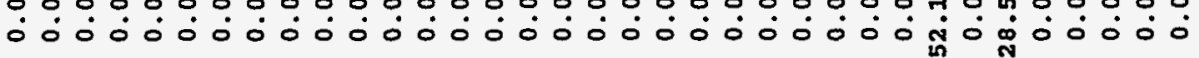

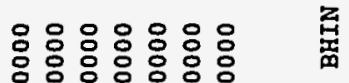

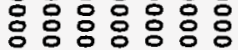
í $\dot{0} \dot{0} \dot{0} \dot{0} \dot{0}$

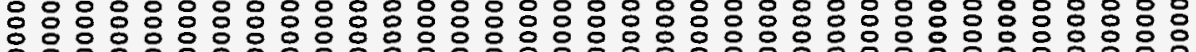

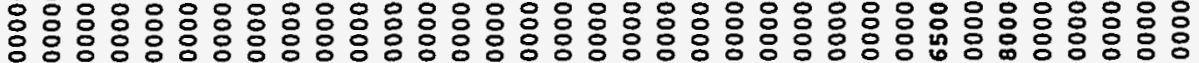

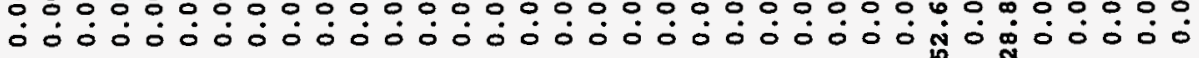

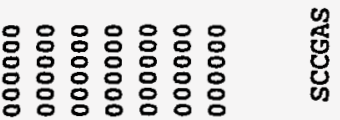
$\dot{0} \dot{0} \dot{0} \dot{0} \dot{0} \dot{0}$

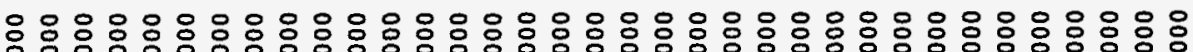

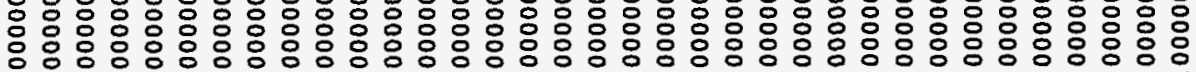

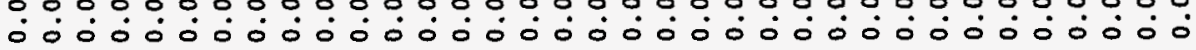

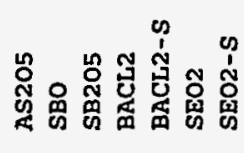

盖

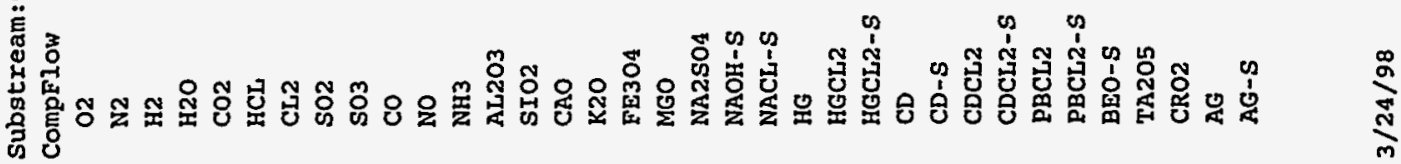




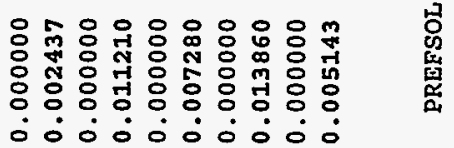

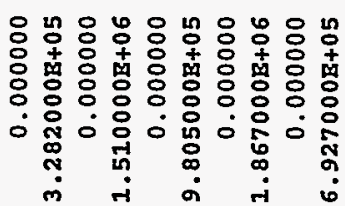

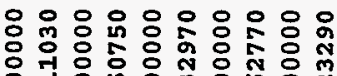

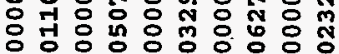
$\dot{0} \dot{0} \dot{0} \dot{0} \dot{0} \dot{0} \dot{0} \dot{0} \dot{0}$

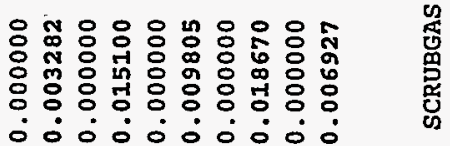

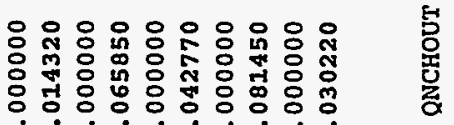

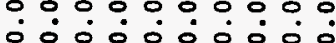

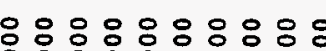
응융ㅇㅇㅇㅇㅇㅇㅇㅇㅇㅇㅇㅇㅇㅇㅇㅇ

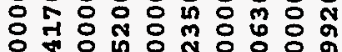
$\dot{0} \dot{0} \dot{0} \dot{0} \dot{0} \dot{0} \dot{0} \dot{0}$

융융ㅇㅇㅇㅇㅇㅇㅇㅇㅇㅇㅠ 省

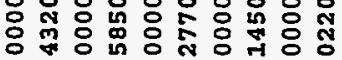

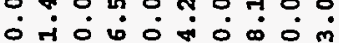

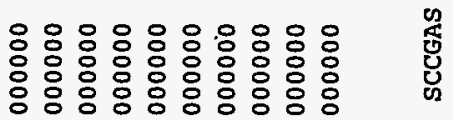
ó:

渵

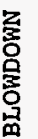

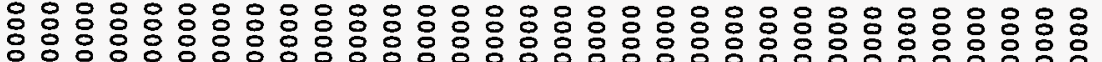

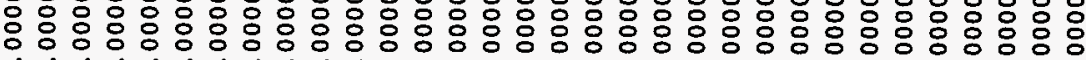
$\dot{0} \dot{0} \dot{0} \dot{0} \dot{0} \dot{0} \dot{0} \dot{0} \dot{0} \dot{0} \dot{0} \dot{0} \dot{0} \dot{0} \dot{0} \dot{0} \dot{0} \dot{0} \dot{0} \dot{0} \dot{0} \dot{0} \dot{0} \dot{0} \dot{0} \dot{0} \dot{0} \dot{0}$

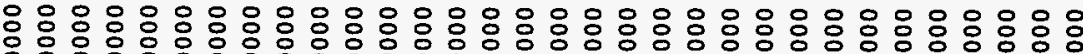

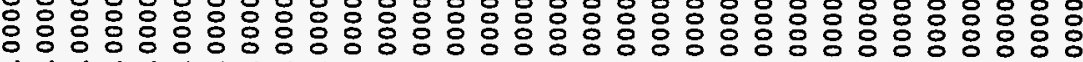
$\dot{0} \dot{0} \dot{0} \dot{0} \dot{0} \dot{0} \dot{0} \dot{0} \dot{0} \dot{0} \dot{0} \dot{0} \dot{0} \dot{0} \dot{0} \dot{0} \dot{0} \dot{0} \dot{0} \dot{0} \dot{0} \dot{0} \dot{0} \dot{0} \dot{0} \dot{0} \dot{0} \dot{0}$

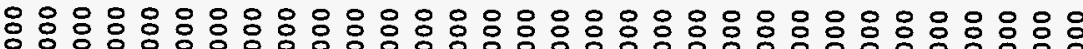

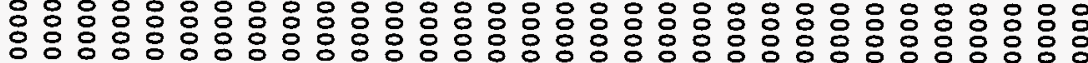

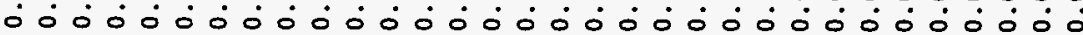

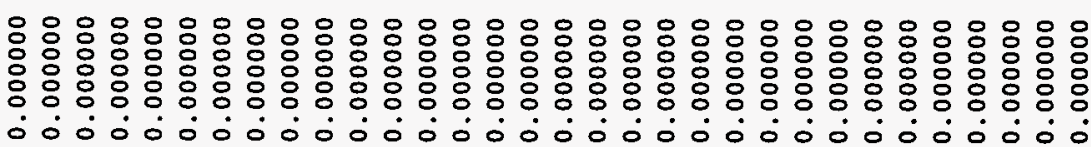

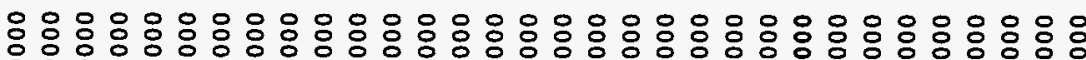

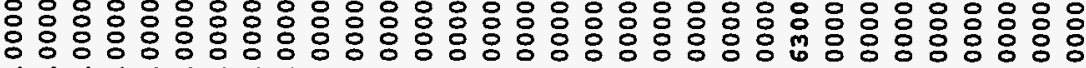

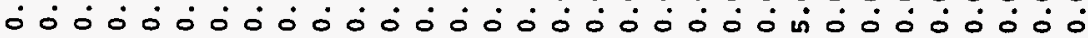

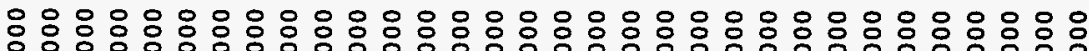

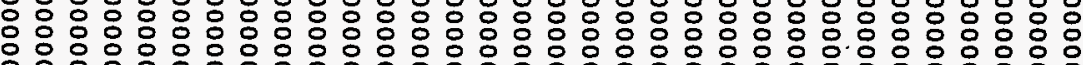

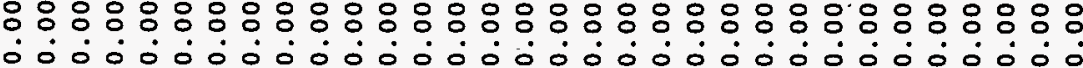

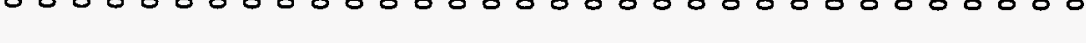

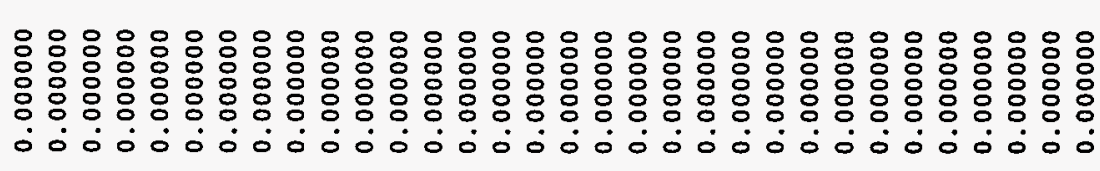

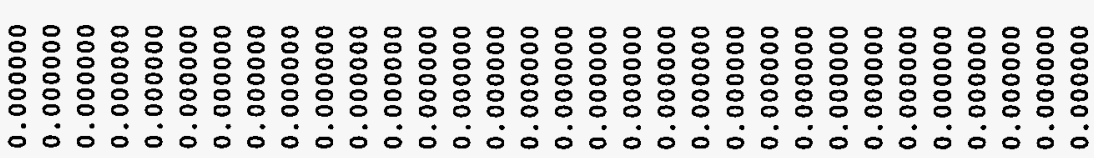

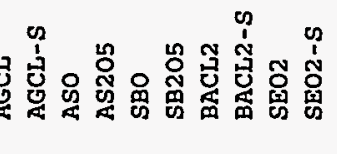

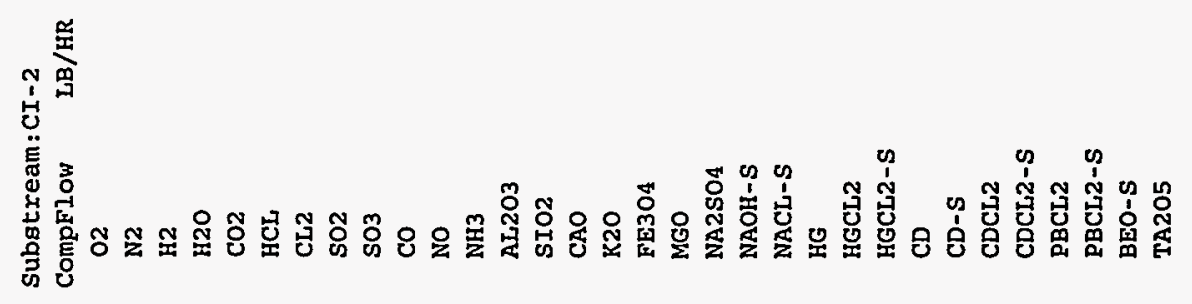




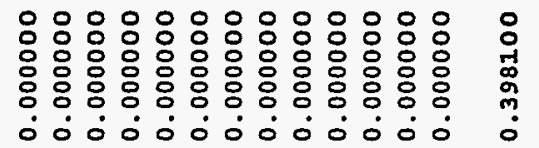

$\begin{aligned} & 0 \\ \vdots & 0\end{aligned}$

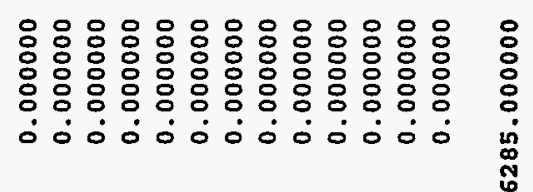

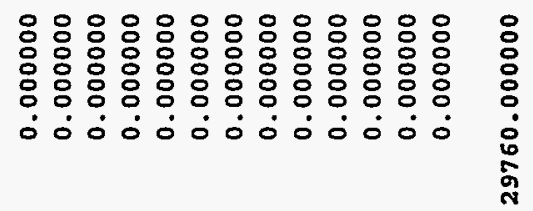

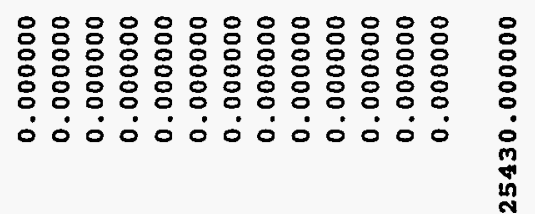

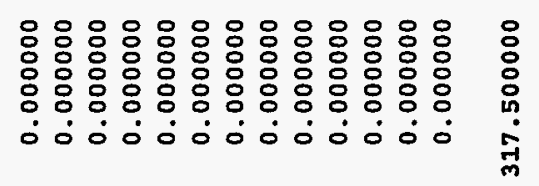

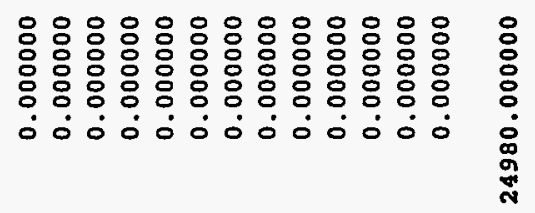

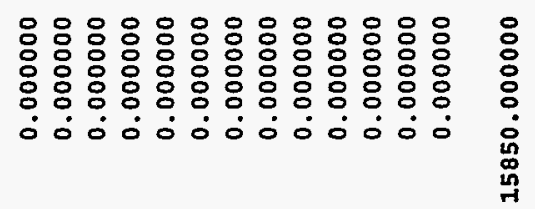

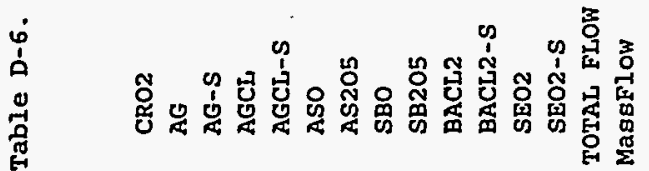




\begin{tabular}{|c|c|c|c|c|c|c|c|c|}
\hline \multicolumn{3}{|c|}{ HEPAIIN } & HEPASOL 1 & HEPAGAS1 & HEPA2IN & \multirow{2}{*}{$\begin{array}{l}\text { HEPASOL2 } \\
0.000000\end{array}$} & \multirow{2}{*}{$\begin{array}{l}\text { HEPAGAS2 } \\
195.000000\end{array}$} & \multirow{2}{*}{$\begin{array}{r}\text { EXITGAS } \\
400.000000\end{array}$} \\
\hline 195.000000 & Temp & F & 0.000000 & 195.000000 & 195.000000 & & & \\
\hline \multirow[t]{3}{*}{12.184000} & Pres & PS & 12.112000 & 12.112000 & 12.112000 & 12.039000 & 12.039000 & 12.039000 \\
\hline & Substream: & LXED & & & & & & \\
\hline & CompFlow & $\mathrm{LB} / \mathrm{HR}$ & & & & & & \\
\hline $3.936000 \mathrm{E}+11$ & 02 & & 0.000000 & $3.936000 \mathrm{~B}+11$ & $3.936000 \mathrm{E}+15$ & 0.000000 & $3.936000 \mathrm{E}+15$ & 3915.000000 \\
\hline $5.444000 \mathrm{~B}+11$ & N2 & & 0.000000 & $5.444000 \mathrm{~B}+11$ & $5.444000 \mathrm{~B}+15$ & 0.000000 & $5.444000 \mathrm{~B}+15$ & 5498.000000 \\
\hline 0.000000 & Н2 & & 0.000000 & 0.000000 & 0.000000 & 0.000000 & 0.000000 & $4.417000 \mathrm{~B}-21$ \\
\hline $1.402000 \mathrm{E}+12$ & $\mathrm{H} 2 \mathrm{O}$ & & 0.000000 & $1.402000 \mathrm{~B}+12$ & $1.402000 \mathrm{~B}+16$ & 0.000000 & $1.402000 \mathrm{E}+16$ & 14080.000000 \\
\hline $6.939000 \mathrm{E}+11$ & $\mathrm{CO} 2$ & & 0.000000 & $6.939000 \mathrm{E}+11$ & $6.939000 \mathrm{~B}+15$ & 0.000000 & $6.939000 \mathrm{~B}+15$ & 6939.000000 \\
\hline $4.754 .000 \mathrm{~B}+07$ & HCL & & 0.000000 & $4.754000 \mathrm{~B}+07$ & $4.754000 \mathrm{E}+11$ & 0.000000 & $4.754000 \mathrm{E}+11$ & 0.475400 \\
\hline 0.000000 & CL2 & & 0.000000 & 0.000000 & 0.000000 & 0.000000 & 0.000000 & 0.000000 \\
\hline $3.154000 \mathrm{E}+07$ & so2 & & 0.000000 & $3.154000 \mathrm{E}+07$ & $3.154000 \mathrm{E}+11$ & 0.000000 & $3.154000 \mathrm{E}+11$ & 0.315400 \\
\hline 0.000000 & SO3 & & 0.000000 & 0.000000 & 0.000000 & 0.000000 & 0.000000 & 0.000000 \\
\hline 0.000000 & co & & 0.000000 & 0.000000 & 0.000000 & 0.000000 & 0.000000 & $6.064000 \mathrm{~B}-23$ \\
\hline $6.310000 \mathrm{E}+09$ & No & & 0.000000 & $6.310000 \mathrm{~B}+09$ & $6.310000 \mathrm{~B}+13$ & 0.000000 & $6.310000 \mathrm{~B}+13$ & 9.465000 \\
\hline 0.000000 & NH3 & & 0.000000 & 0.000000 & 0.000000 & 0.000000 & 0.000000 & 0.358100 \\
\hline 0.000000 & AL2O3 & & 0.000000 & 0.000000 & 0.000000 & 0.000000 & 0.000000 & 0.000000 \\
\hline 0.000000 & $\mathrm{SIO2}$ & & 0.000000 & 0.000000 & 0.000000 & 0.000000 & 0.000000 & 0.000000 \\
\hline 0.000000 & CAO & & 0.000000 & 0.000000 & 0.000000 & 0.000000 & 0.000000 & 0.000000 \\
\hline 0.000000 & к20 & & 0.000000 & 0.000000 & 0.000000 & 0.000000 & 0.000000 & 0.000000 \\
\hline 0.000000 & FE304 & & 0.000000 & 0.000000 & 0.000000 & 0.000000 & 0.000000 & 0.000000 \\
\hline 0.000000 & MGO & & 0.000000 & 0.000000 & 0.000000 & 0.000000 & 0.000000 & 0.000000 \\
\hline 0.000000 & NA2SO4 & & 0.000000 & 0.000000 & 0.000000 & 0.000000 & 0.000000 & 0.000000 \\
\hline 0.000000 & NAOH-S & & 0.000000 & 0.000000 & 0.000000 & 0.000000 & 0.000000 & 0.000000 \\
\hline 0.000000 & NACL-S & & 0.000000 & 0.000000 & 0.000000 & 0.000000 & 0.000000 & 0.000000 \\
\hline 0.000000 & HG & & 0.000000 & 0.000000 & 0.000000 & 0.000000 & 0.000000 & 0.000000 \\
\hline $4.270000 \mathrm{E}+06$ & HGCL2 & & 0.000000 & $4.270000 \mathrm{E}+06$ & $4.270000 \mathrm{E}+08$ & 0.000000 & $4.270000 E+08$ & $4.270000 \mathrm{E}-04$ \\
\hline 0.000000 & HGCL2-S & & 0.000000 & 0.000000 & 0.000000 & 0.000000 & 0.000000 & 0.000000 \\
\hline 0.000000 & CD & & 0.000000 & 0.000000 & 0.000000 & 0.000000 & 0.000000 & 0.000000 \\
\hline 0.000000 & CD-S & & 0.000000 & 0.000000 & 0.000000 & 0.000000 & 0.000000 & 0.000000 \\
\hline 0.000000 & CDCL2 & & 0.000000 & 0.000000 & 0.000000 & 0.000000 & 0.000000 & 0.000000 \\
\hline 0.000000 & CDCL2-S & & 0.000000 & 0.000000 & 0.000000 & 0.000000 & 0.000000 & 0.000000 \\
\hline 0.000000 & PBCL2 & & 0.000000 & 0.000000 & 0.000000 & 0.000000 & 0.000000 & 0.000000 \\
\hline 0.000000 & PBCL2-S & & 0.000000 & 0.000000 & 0.000000 & 0.000000 & 0.000000 & 0.000000 \\
\hline 0.000000 & BEO-S & & 0.000000 & 0.000000 & 0.000000 & 0.000000 & 0.000000 & 0.000000 \\
\hline 0.000000 & TA205 & & 0.000000 & 0.000000 & 0.000000 & 0.000000 & 0.000000 & 0.000000 \\
\hline 0.000000 & CRO2 & & 0.000000 & 0.000000 & 0.000000 & 0.000000 & 0.000000 & 0.000000 \\
\hline 0.000000 & AG & & 0.000000 & 0.000000 & 0.000000 & 0.000000 & 0.000000 & 0.000000 \\
\hline 0.000000 & $A G-S$ & & 0.000000 & 0.000000 & 0.000000 & 0.000000 & 0.000000 & 0.000000 \\
\hline 0.000000 & AGCL & & 0.000000 & 0.000000 & 0.000000 & 0.000000 & 0.000000 & 0.000000 \\
\hline 0.000000 & AGCL-S & & 0.000000 & 0.000000 & 0.000000 & 0.000000 & 0.000000 & 0.000000 \\
\hline 0.000000 & ASO & & 0.000000 & 0.000000 & 0.000000 & 0.000000 & 0.000000 & 0.000000 \\
\hline 0.000000 & AS205 & & 0.000000 & 0.000000 & 0.000000 & 0.000000 & 0.000000 & 0.000000 \\
\hline 0.000000 & SBO & & 0.000000 & 0.000000 & 0.000000 & 0.000000 & 0.000000 & 0.000000 \\
\hline 0.000000 & SB205 & & 0.000000 & 0.000000 & 0.000000 & 0.000000 & 0.000000 & 0.000000 \\
\hline 0.000000 & BACL2 & & 0.000000 & 0.000000 & 0.000000 & 0.000000 & 0.000000 & 0.000000 \\
\hline
\end{tabular}




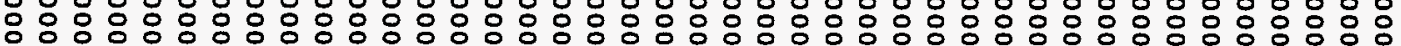
$\dot{0} \dot{0} \dot{0} \dot{0} \dot{0} \dot{0} \dot{0} \dot{0} \dot{0} \dot{0} \dot{0} \dot{0} \dot{0} \dot{0} \dot{0} \dot{0} \dot{0} \dot{0} \dot{0} \dot{0} \dot{0} \dot{0} \dot{0} \dot{0} \dot{0} \dot{0} \dot{0} \dot{0} \dot{0} \dot{0} \dot{0} \dot{0} \dot{0} \dot{0} \dot{0} \dot{0} \dot{0} \dot{0} \dot{0} \dot{0}$

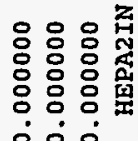

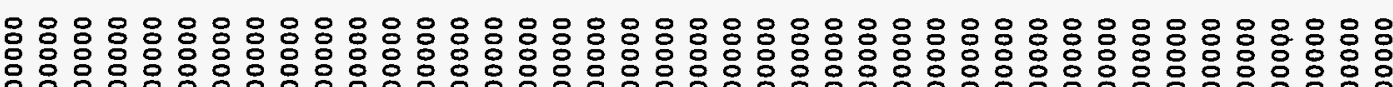

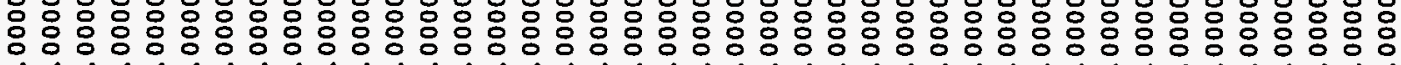

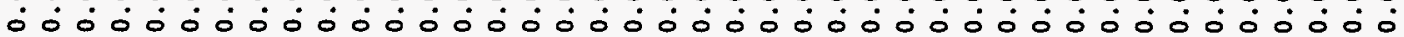
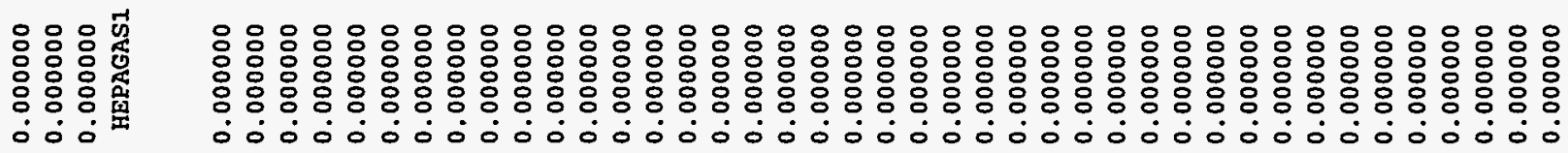

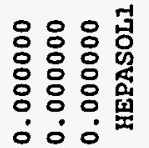

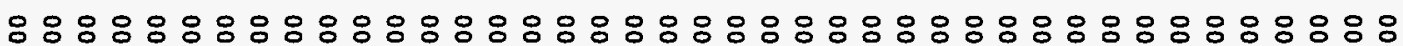

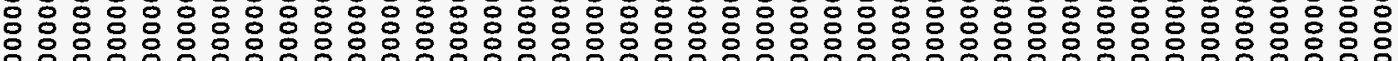

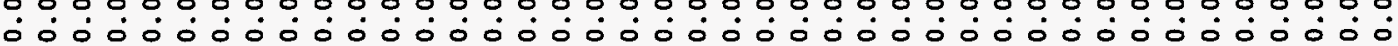

至

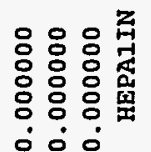

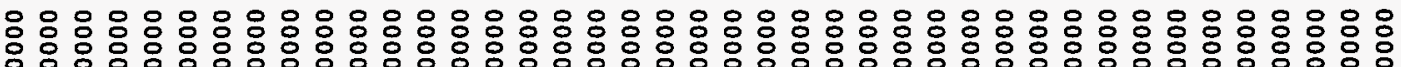

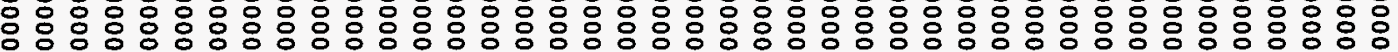
$\dot{0} \dot{0} \dot{0} \dot{0} \dot{0} \dot{0} \dot{0} \dot{0} \dot{0} \dot{0} \dot{0} \dot{0} \dot{0} \dot{0} \dot{0} \dot{0} \dot{0} \dot{0} \dot{0} \dot{0} \dot{0} \dot{0} \dot{0} \dot{0} \dot{0} \dot{0} \dot{0} \dot{0} \dot{0} \dot{0} \dot{0} \dot{0} \dot{0}$ 
Table D-6. Simulation results for primary streams in low-flow case.

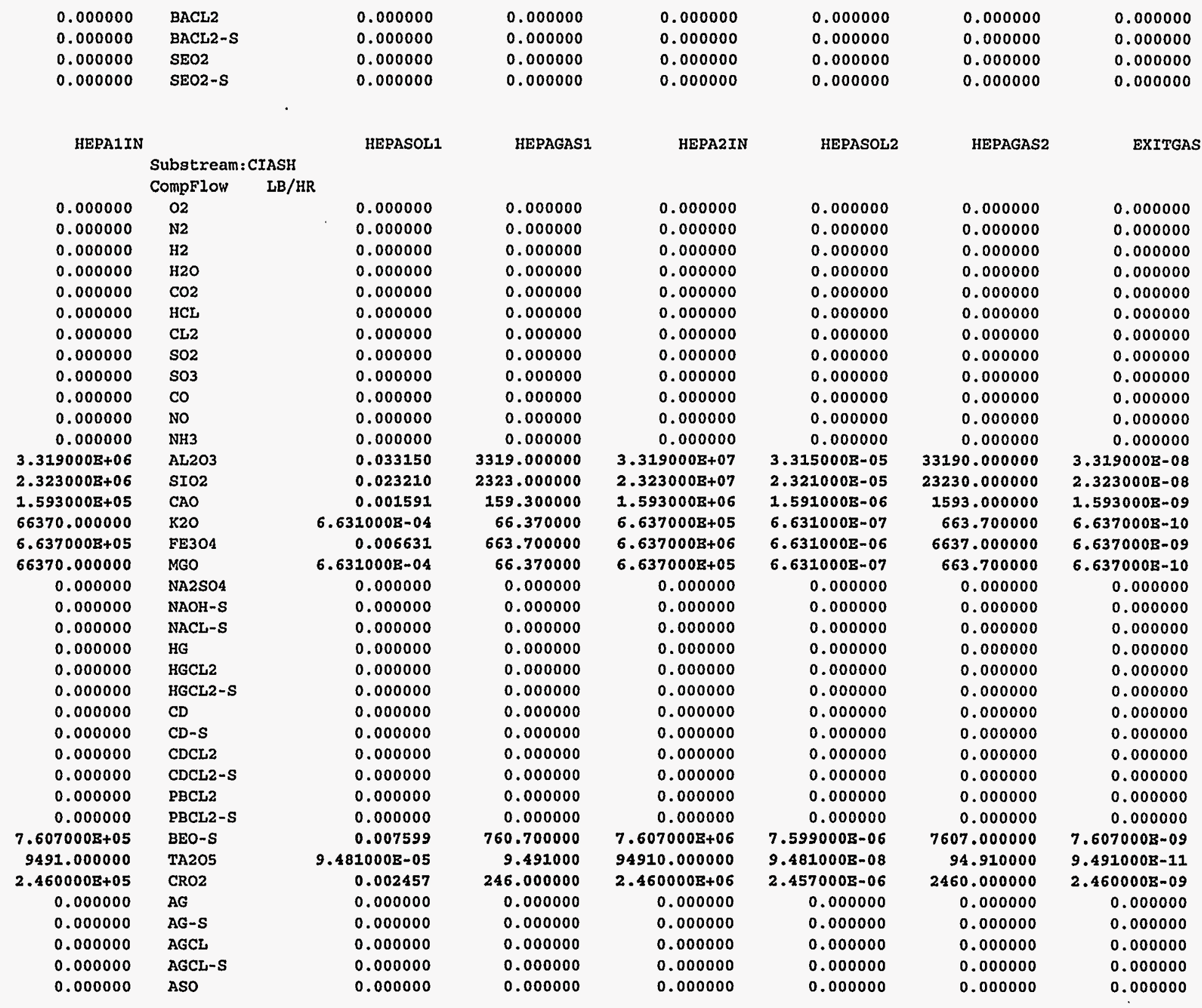


Table D-6. Simulation results for primary streams in low-flow case.

$\begin{array}{lll}0.000000 & \text { AS205 } & 0.000000 \\ 0.000000 & \text { SBO } & 0.000000 \\ 0.000000 & \text { SB205 } & 0.000000 \\ 0.000000 & \text { BACL2 } & 0.000000 \\ 0.000000 & \text { BACL2-S } & 0.000000 \\ 0.000000 & \text { SEO2 } & 0.000000 \\ 0.000000 & \text { SEO2-S } & 0.000000\end{array}$

0.000000
0.000000
0.000000
0.000000
0.000000
0.000000
0.000000

0.000000
0.000000
0.000000
0.000000
0.000000
0.000000
0.000000

0.000000
0.000000
0.000000
0.000000
0.000000
0.000000
0.000000

0.000000

0.000000

0.000000

.000000

0.000000

0.000000

0.000000

$0.000000 \quad 0.000000$

0.000000

0.000000

0.000000

0.000000

HEPASOL1

HEPAGAS1

HEPA2IN

HEPASOL2

HEPAGAS2

0.000000

0.000000

Substream: CI-

$\begin{array}{ll}0.000000 & \text { O2 } \\ 0.000000 & \text { N2 } \\ 0.000000 & \text { H2 } \\ 0.000000 & \text { H2O }\end{array}$

0.000000

0.000000

0.000000

0.000000

0.000000

0.000000

0.000000

0.000000

0.000000

0.000000

0.000000

0.000000

0.000000

0.000000

0.000000

0.000000

0.000000

0.000000

0.000000

0.000000

0.000000

0.000000

0.000000

0.000000

0.000000

0.000000

0.000000

0.000000

0.000000

0.000000

0.000000

HGCL2-S

CD-S

CDCL2

$3.1080008+06$ CDCL2-S

0.000000 PBCL2

$1.700000 \mathrm{~B}+06$ PBCL2-S

0.000000 BEO-S

$0.000000 \quad$ TA205

0.000000 CRO2

$0.000000 \quad A G$

0.000000 AG-S

08.000000

0.000000

0.031050

0.000000

0.016980

0.000000

0.000000

0.000000

0.000000

0.000000

1700.000000

0.000000

0.000000

0.000000

0.000000

0.000000

0.00000

0.000000

0.000000

0.000000

0.000000

0.000000

0.000000

0.000000

0.000000

0.000000

0.000000

0.000000

0.000000

0.000000

0.000000

0.000000

0.000000

0.000000

0.000000

0.000000

0.000000

0.000000

0.000000

0.000000

0.000000

0.000000

$3.108000 \mathrm{~B}+07$

0.000000

$1.7000008+07$

0.000000

0.000000

0.000000

0.000000

0.000000

0.000000

0.000000

0.000000

0.000000

0.000000

0.000000

0.000000

0.000000

0.000000

0.000000

0.000000

0.000000

0.000000

0.000000

0.000000

0.000000

0.000000

0.000000

0.000000

0.000000

0.000000

0.000000

0.000000

0.000000

0.000000

$3.105000 \mathrm{~B}-05$

0.000000

$1.698000 \mathrm{~B}-05$

0.000000

0.000000

0.000000

0.000000

0.000000

0.000000

0.000000

0.000000

0.000000

0.000000

0.000000

0.000000

0.000000

0.000000

0.000000

0.000000

0.000000

0.000000

0.000000

0.000000

0.000000

0.000000

0.000000

0.000000

0.000000

0.000000

0.000000

0.000000

0.000000

0.000000

0.000000

0.000000

31080.000000

0.000000

17000.000000

0.000000

0.000000

0.000000

0.000000

0.000000

EXITGAS

0.000000

0.000000

0.000000

0.000000

0.000000

0.000000

0.000000

0.000000

0.000000

0.000000

0.000000

0.000000

0.000000

0.000000

0.000000

0.000000

0.000000

0.000000

0.000000

0.000000

0.000000

0.000000

0.000000

0.000000

0.000000

0.000000

0.000000

$3.1080008-08$

0.000000

$1.700000 \mathrm{E}-08$

0.000000

0.000000

0.000000

0.000000

0.000000 


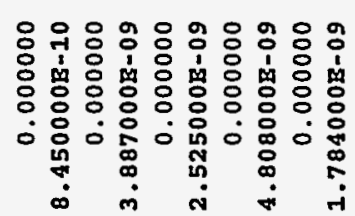

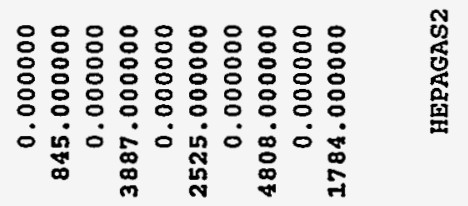

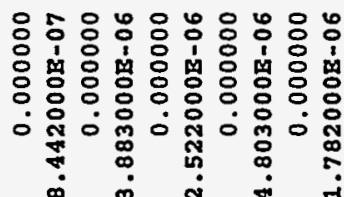

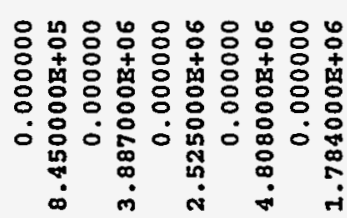
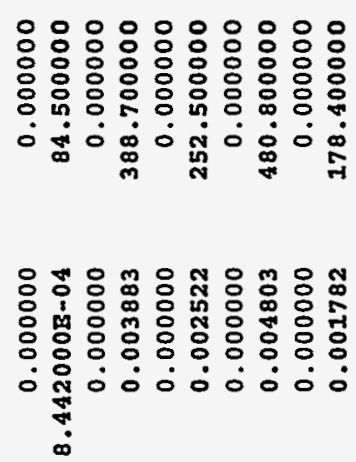

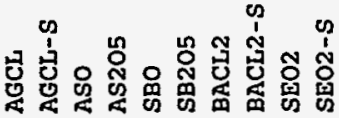

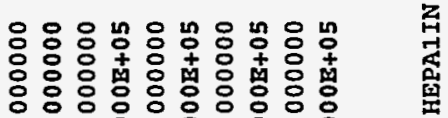

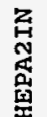

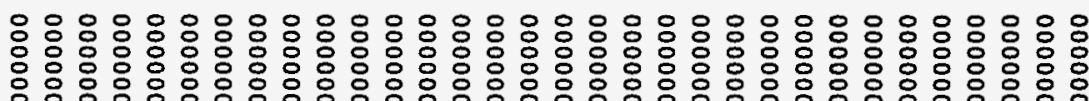
$\dot{0} \dot{0} \dot{0} \dot{0} \dot{0} \dot{0} \dot{0} \dot{0} \dot{0} \dot{0} \dot{0} \dot{0} \dot{0} \dot{0} \dot{0} \dot{0} \dot{0} \dot{0} \dot{0} \dot{0} 0 \dot{0} 0 \dot{0} 0 \dot{0} 0 \dot{0} 0$

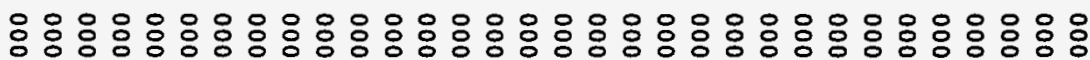

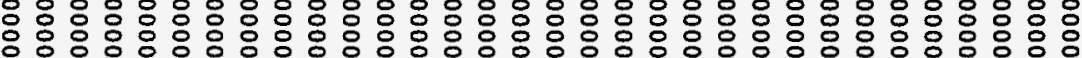
$\dot{0} \dot{0} \dot{0} \dot{0} \dot{0} \dot{0} \dot{0} \dot{0} \dot{0} \dot{0} \dot{0} \dot{0} \dot{0} \dot{0} \dot{0} \dot{0} \dot{0} \dot{0} \dot{0} \dot{0} \dot{0} \dot{0} \dot{0} \dot{0} \dot{0} \dot{0} \dot{0} \dot{0} \dot{0} \dot{0} \dot{0}$

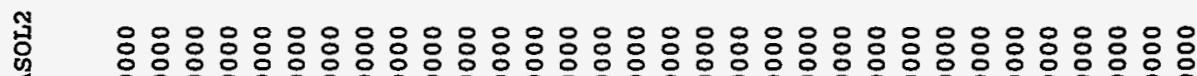

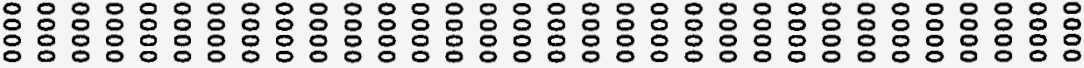
$\dot{0} \dot{0} \dot{0} \dot{0} \dot{0} \dot{0} \dot{0} \dot{0} \dot{0} \dot{0} \dot{0} \dot{0} \dot{0} \dot{0} \dot{0} \dot{0} \dot{0} \dot{0} \dot{0} \dot{0} \dot{0} \dot{0} \dot{0} \dot{0} \dot{0} \dot{0} \dot{0} \dot{0} \dot{0} 0 \dot{0} \dot{0}$

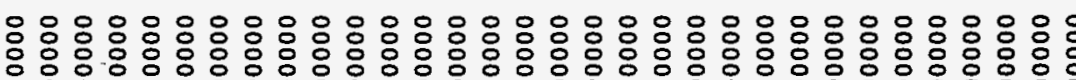

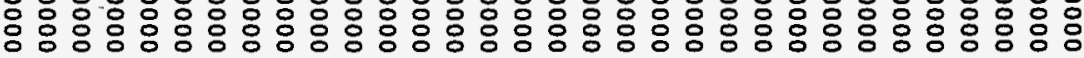
$\dot{0} \dot{0} \dot{0} \dot{0} \dot{0} \dot{0} \dot{0} \dot{0} \dot{0} \dot{0} \dot{0} \dot{0} \dot{0} \dot{0} \dot{0} \dot{0} \dot{0} \dot{0} \dot{0} \dot{0} \dot{0} \dot{0} \dot{0} \dot{0} \dot{0} \dot{0} \dot{0}$

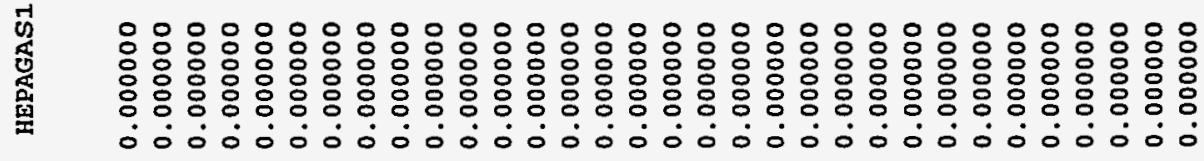

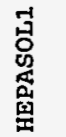

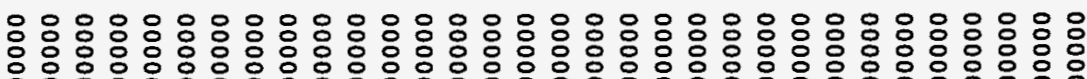

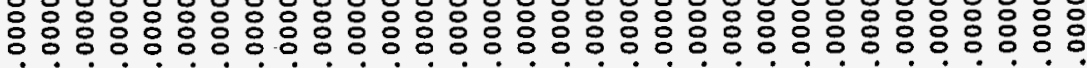
$\dot{0} \dot{0} \dot{0} \dot{0} \dot{0} \dot{0} \dot{0} \dot{0} \dot{0} \dot{0} \dot{0} \dot{0} \dot{0} \dot{0} \dot{0} \dot{0} \dot{0} \dot{0} \dot{0} \dot{0} \dot{0} \dot{0} \dot{0} \dot{0} \dot{0} \dot{0} \dot{0} \dot{0} \dot{0} 0 \dot{0}$<smiles>C=CCOCCO</smiles>

ب.

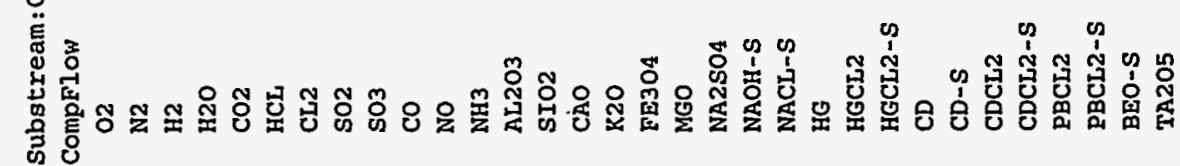

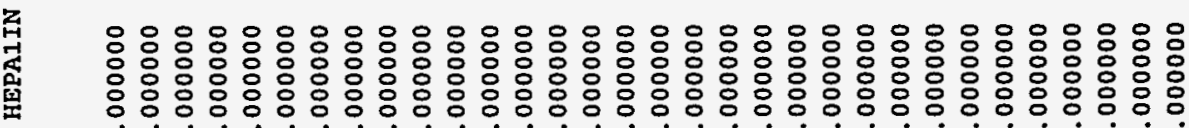


Table D-6. Simulation results for primary streams in low-flow case.

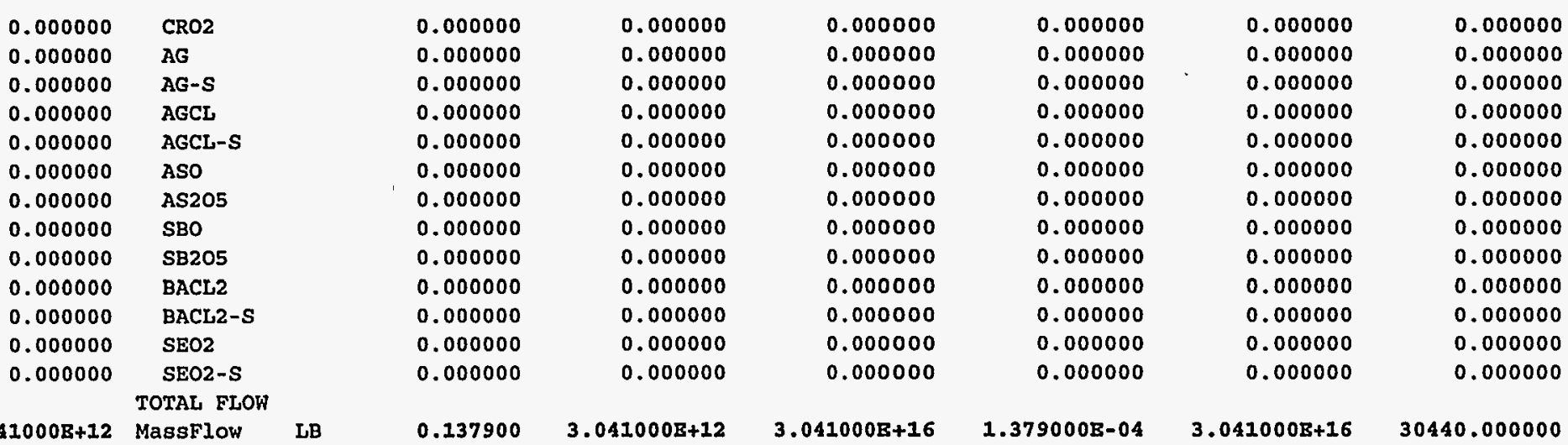

